TJARK HUIZINGA

DEVELOPING
CURRICULUM

DESIEN EXPERTISE

TAROUGM TEACAER

DESIGN TEAMS

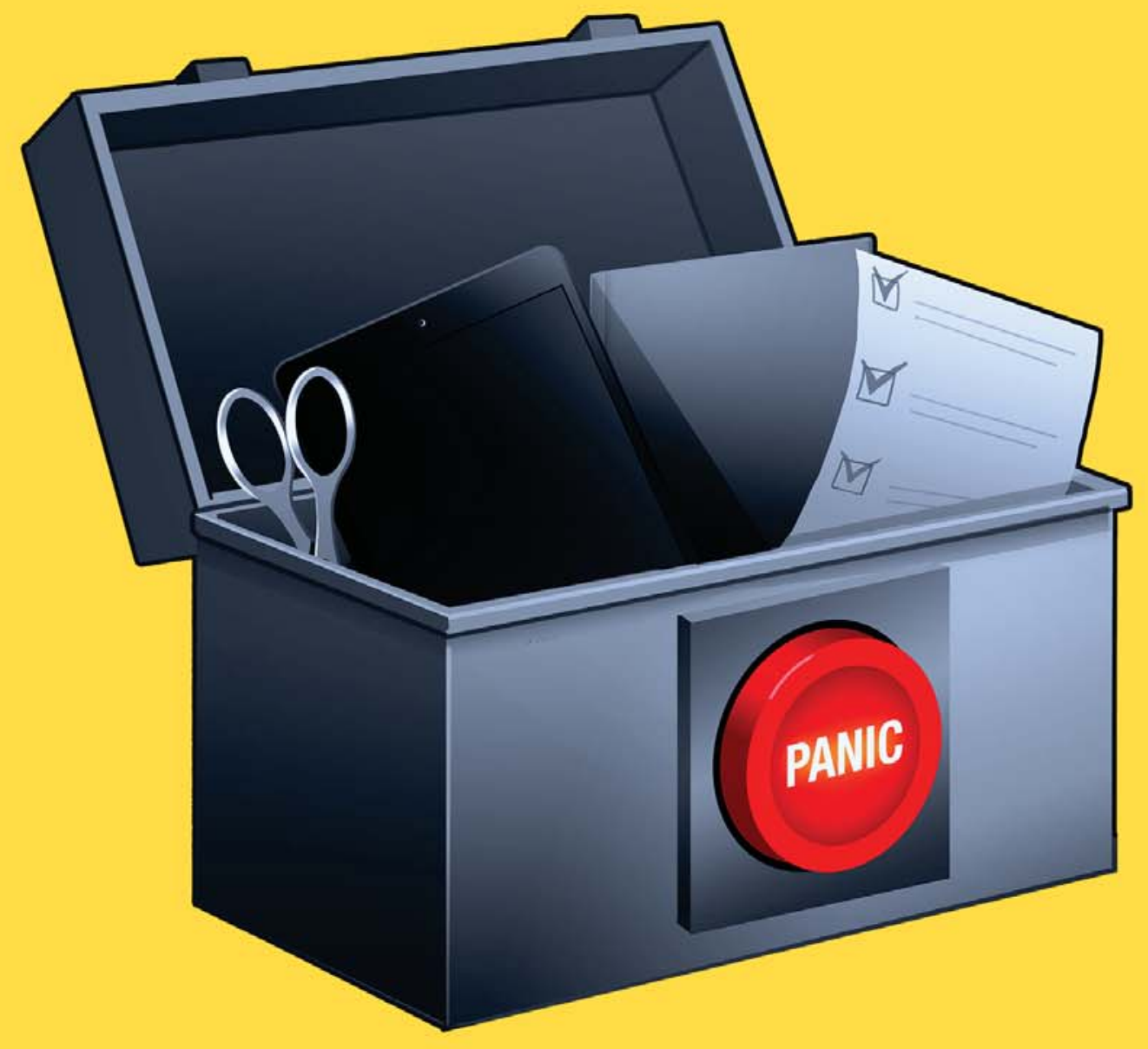




\section{DEVELOPING CURRICULUM DESIGN EXPERTISE THROUGH TEACHER DESIGN TEAMS}

Tjark Huizinga 


\section{DOCTORAL COMMITTEE}

Chairman Prof. dr. ir. A. J. Mouthaan - University of Twente

Promotors Prof. dr. J. M. Voogt - University of Amsterdam

Prof. dr. J. M. Pieters - University of Twente

Co-promotor Dr. A. Handelzalts - VU University Amsterdam

Members $\quad$ Prof. dr. J. J. H. van den Akker - University of Twente

Prof. dr. J. J. G. van Merriënboer • Maastricht University

Prof. dr. M. L. L. Volman - University of Amsterdam

Dr. S. E. McKenney - University of Twente

Dr. N. M. Nieveen -SLO, Netherlands Institute for Curriculum Development

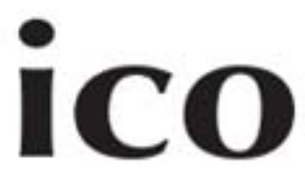

Huizinga, T.

Developing Curriculum Design Expertise through Teacher Design Teams

Thesis University of Twente, Enschede.

ISBN 978-90-365-3769-8

DOI 10.3990/1.9789036537698

Cover: Edouard Relou

Lay-out: Tjark Huizinga

Printer: Ipskamp Drukkers B.V. Enschede

(C) Copyright, 2014, T. Huizinga 


\title{
DEVELOPING CURRICULUM DESIGN EXPERTISE THROUGH TEACHER DESIGN TEAMS
}

\author{
DISSERTATION \\ to obtain \\ the degree of doctor at the University of Twente, \\ on the authority of the rector magnificus, \\ prof. dr. H. Brinksma, \\ on account of the decision of the graduation committee \\ to be publicly defended \\ on Friday 12th of December 2014 at 14:45 \\ by \\ Tjark Huizinga \\ born on the $5^{\text {th }}$ of December, 1984 \\ in Apeldoorn, The Netherlands
}


Promotors

Prof. dr. J. M. Voogt

Prof. dr. J. M. Pieters

Co-promotor

Dr. A. Handelzalts

This dissertation has been approved by the promotors and co-promotor 


\section{TABLE OF CONTENTS}

LIST OF FIGURES AND TABLES vi vi

$\begin{array}{ll}\text { 1. INTRODUCTION } & 1\end{array}$

1.1 Origins of the study 1

1.2 Aim of the study 4

1.3 Conceptual framework 4

1.3.1 Curriculum 5

$\begin{array}{ll}\text { 1.3.2 Design expertise } & 6\end{array}$

1.3.3 Specific design expertise 9

1.3.4 Developing curriculum design expertise through TDTs 13

1.4 Context of this study 14

$\begin{array}{ll}1.5 \text { Research design } & 17\end{array}$

$\begin{array}{lll}\text { 1.5.1 Research questions } & 17\end{array}$

$\begin{array}{ll}1.5 .2 \text { Research methods } & 17\end{array}$

$\begin{array}{ll}1.6 \text { Overview of the dissertation } & 20\end{array}$

2. TEACHER INVOLVEMENT IN CURRICULUM DESIGN: NEED FOR SUPPORT TO ENHANCE TEACHERS' CURRICULUM DESIGN EXPERTISE 21

2.1 Introduction 21

2.2 Defining teachers' design expertise 23

2.2.1 Curriculum design expertise 25

2.2.2 Subject matter knowledge 26

2.2.3 Pedagogical content knowledge 26

$\begin{array}{ll}\text { 2.2.4 Curriculum consistency expertise } & 27\end{array}$

2.3 Support to enhance teachers' design expertise 27

2.4 Methods 29

2.4.1 Respondents 29

2.4.2 Instruments 31

$\begin{array}{lll}2.4 .3 & \text { Data analysis } & 32\end{array}$ 
2.5 Findings 34

2.5.1 Curriculum design expertise 35

2.5.2 Subject matter knowledge 37

2.5.3 Pedagogical content knowledge 37

2.5.4 Curriculum consistency expertise 38

2.6 Conclusions and discussion $\quad 40$

2.6.1 Curriculum design expertise 40

2.6.2 Pedagogical content knowledge 42

2.6.3 Curriculum consistency expertise 43

2.6.4 Limitations 44

2.6.5 Recommendations 44

3. FOSTERING TEACHERS' CURRICULUM DESIGN EXPERTISE IN TEACHER DESIGN TEAMS: CONDUCIVE DESIGN AND SUPPORT ACTIVITIES 47

3.1 Introduction 47

3.2 Teachers' design expertise $\quad 49$

3.2.1 Defining teachers' design expertise 49

3.2.2 Curriculum design expertise 50

3.2.3 Subject matter knowledge 50

3.2.4 Pedagogical content knowledge 50

3.3 Support for Teacher Design Teams 51

3.4 Research design 52

3.4.1 Case selection 52

3.4.2 Instrumentation 53

3.4.3 Data analysis $\quad 55$

3.5 Results 56

3.5.1 Case 1 - Plato's design activities 56

3.5.2 Case 2 - Thales' design activities 62

$\begin{array}{ll}3.6 \text { Conclusion and discussion } & 67\end{array}$

3.6.1 TDTs' design and support activities 67

3.6.2 Developing curriculum design expertise 68

$\begin{array}{ll}\text { 3.6.3 PCK and SMK } & 70\end{array}$

$\begin{array}{ll}\text { 3.6.4 Storyline approach } & 70\end{array}$ 
4. IMPLEMENTATION AND EVALUATION ACTIVITIES IN DESIGN TEAMS: OPPORTUNITIES FOR ENHANCING TEACHERS' CURRICULUM DESIGN EXPERTISE

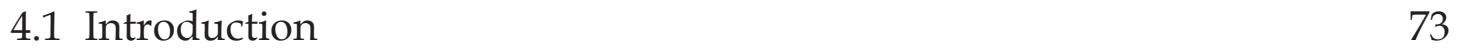

4.2 Curriculum design expertise $\quad 75$

4.2.1 Expertise required for implementation 75

$\begin{array}{ll}\text { 4.2.2 Expertise required for evaluation } & 77\end{array}$

$\begin{array}{ll}4.3 \text { Research design } & 79\end{array}$

$\begin{array}{lll}\text { 4.3.1 Case selection } & 79\end{array}$

4.3.2 Procedure and instrumentation 80

$\begin{array}{lll}\text { 4.3.3 Data analysis } & 82\end{array}$

4.4 Results 83

4.4.1 Case 1 - Plato's implementation and evaluation process 83

4.4.2 Case 2 - Thales' implementation and evaluation process 89

4.4.3 Case 3-Othello's implementation and evaluation process 93

$\begin{array}{ll}4.5 \text { Conclusion } & 100\end{array}$

4.5.1 TDTs' implementation and evaluation activities and $\begin{array}{ll}\text { corresponding experiences } & 100\end{array}$

4.5.2 Teachers' classroom implementation and evaluation

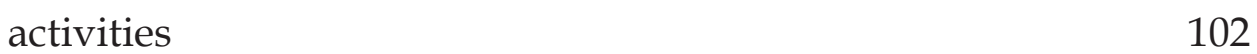

$\begin{array}{ll}\text { 4.5.3 Overall conclusion } & 103\end{array}$

$\begin{array}{ll}4.6 \text { Discussion } & 103\end{array}$

5. FACTORS AFFECTING TEACHERS' ABILITY TO TACKLE DESIGN $\begin{array}{ll}\text { CHALLENGES } & 107\end{array}$

$\begin{array}{ll}5.1 \text { Introduction } & 107\end{array}$

$\begin{array}{ll}5.2 \text { Methods } & 111\end{array}$

5.2.1 Design of the study 111

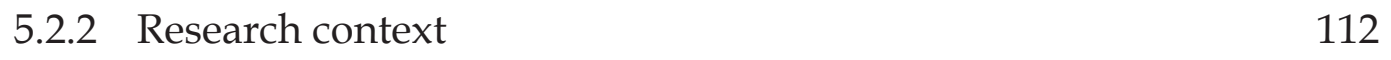

$\begin{array}{lll}\text { 5.2.3 Participants } & 112\end{array}$

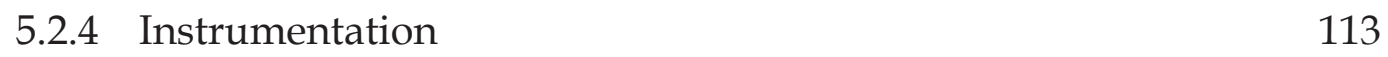

$\begin{array}{lll}\text { 5.2.5 Data analysis } & 115\end{array}$ 
$\begin{array}{ll}5.3 \text { Results } & 116\end{array}$

$\begin{array}{lll}\text { 5.3.1 Descriptive statistics and correlations } & 116\end{array}$

$\begin{array}{ll}\text { 5.3.2 The null model } & 118\end{array}$

$\begin{array}{lll}\text { 5.3.3 } & \text { Model } 1 & 118\end{array}$

5.3.4 Model 2

$\begin{array}{lll}\text { 5.3.5 } & 119\end{array}$

$\begin{array}{lll}\text { 5.3.6 } & \text { Model } 4 & 119\end{array}$

$\begin{array}{lll}\text { 5.3.7 } & \text { Model } 5 & 119\end{array}$

5.3.8 Model $6 \quad 119$

$\begin{array}{lll}5.3 .9 & \text { Final model } & 122\end{array}$

$\begin{array}{ll}5.4 \text { Conclusion and discussion } & 122\end{array}$

$\begin{array}{ll}\text { 6. SUMMARY AND DISCUSSION } & 127\end{array}$

$\begin{array}{ll}6.1 \text { Overview of the study } & 127\end{array}$

$\begin{array}{ll}6.2 \text { Summary of the findings } & 129\end{array}$

6.2.1 First study - Need for support to enhance teachers' curriculum design expertise $\quad 129$

6.2.2 Second study - Fostering teachers' curriculum design expertise in Teacher Design Teams 130

6.2.3 Third study - Implementation and evaluation activities in design teams 130

6.2.4 Fourth study - Factors affecting teachers' ability to tackle design challenges 131

$\begin{array}{ll}6.3 \text { Conclusion } & 132\end{array}$

6.4 Reflections on the research method 133

6.4.1 General approach: mixed method 133

$\begin{array}{ll}\text { 6.4.2 Storyline method } & 134\end{array}$

$\begin{array}{ll}\text { 6.4.3 Role of the researcher } & 135\end{array}$

6.5 Reflections on the outcomes of the study 136

6.5.1 Teachers as designers 136

6.5.2 Curriculum design expertise 136

6.5.3 Developing curriculum design expertise 137

$\begin{array}{ll}6.6 \text { Recommendations } & 140\end{array}$

$\begin{array}{ll}\text { 6.6.1 Recommendations for practice } & 140\end{array}$

6.6.2 Recommendations for future research 142 
REFERENCES

DUTCH SUMMARY

155

APPENDICES

LIST OF PUBLICATIONS

ICO DISSERTATIONS SERIES

DANKWOORD 


\section{LIST OF FIGURES AND TABLES}

\section{FIGURES}

1.1 Overview of the language levels as described in CEFR 15

2.1 Teachers' design expertise overview 25

3.1 Storylines of the design process as experienced by Plato's TDT 60

3.2 Storylines of the design process as experienced by Thales' lead TDT 65

4.1 Storylines of Plato's team members about the TDT's implementation and evaluation activities

4.2 Storylines of the implementation and evaluation process by $\begin{array}{ll}\text { Thales' TDT } & 91\end{array}$

4.3 Storylines of the implementation and evaluation process by Othello's TDT

5.1 Graphical representation of the (personal, team and management) factors affecting teachers' ability to tackle design challenges

\section{TABLES}

1.1 Definitions addressing design expertise

1.2 Relation between the aspects of curriculum design expertise and why it is $\begin{array}{ll}\text { needed during curriculum design processes } & 11\end{array}$

2.1 Characteristics of the teachers 30

2.2 Characteristics of the facilitators 31

2.3 Examples of deductive coding of the summaries 33

2.4 Examples of inductive coding of the transcriptions 34

2.5 Categorical overview of design expertise addressed in interviews 35

2.6 Overview of teachers' curriculum design expertise 36

2.7 Overview of teachers' subject matter knowledge 37

2.8 Overview of teachers' pedagogical content knowledge 38

2.9 Overview of teachers' curriculum consistency expertise 39 
3.1 Background information for the teams 53

3.2 Data collection per research question 54

3.3 Section of the final codebook 56

3.4 Timeline of Plato's TDT 57

3.5 Focus and content of support offered to Plato's TDT 58

3.6 Timeline of Thales' TDT $\quad 62$

3.7 Focus and content of support offered to Thales' TDT 64

$\begin{array}{lll}3.8 & \text { Comparison between Plato and Thales } & 68\end{array}$

4.1 Expertise needed for conducting implementation (activities) 76

$\begin{array}{lll}4.2 & \text { Expertise needed for conducting evaluation activities } & 78\end{array}$

$\begin{array}{lll}4.3 & \text { Characteristics of the selected cases } & 79\end{array}$

$\begin{array}{ll}4.4 & \text { Data collection per research question }\end{array}$

4.5 Section of the final codebook 82

4.6 Plato's TDT implementation and evaluation activities 84

4.7 Characteristics of the implemented lessons in Plato 87

4.8 Chronological overview of the implementation and evaluation activities in Thales 90

4.9 Characteristics of the implemented lessons in Thales 92

4.10 Overview of the conducted activities in Othello during the implementation and evaluation phases $\quad 95$

4.11 Characteristics of the observed lessons in Othello 98

4.12 TDTs' implementation and evaluation expertise 101

5.1 Overview of the participants per administration of the questionnaire 113

5.2 Descriptive statistics and correlation between the scales per $\begin{array}{ll}\text { administration } & 116\end{array}$

5.3 Teachers' prior experiences in curriculum design per administration $\quad 117$

5.4 Estimates and standard errors from the random intercept model (dependent variable: tackling design challenges) 


\section{CHAPTER 1 Introduction}

This chapter forms a general introduction for the study in this dissertation. The chapter starts with a description of the origins and the aim of the study. Next, the main concepts of the study are introduced: design expertise and developing curriculum design expertise through Teacher Design Teams. After discussing the conceptual framework, the context of this study is introduced, followed by the overall research design. Finally, an outline of the dissertation is provided.

\subsection{ORIGINS OF THE STUDY}

The design and implementation of curriculum reform are complex processes. However, various stakeholders repeatedly overlook this complexity. Therefore, despite the best intentions and ambitions, curriculum reforms too often are only partially implemented or fall short of realizing their educational goals (Fullan, 2007; Green, 1980; Stenhouse, 1975; Van den Akker, 2010). The failure of curriculum reform is often explained by the lack of involvement of the main stakeholder: the teacher (Fullan, 2007; Stenhouse, 1975). As Fullan stated it (1991, p. 117): 'Educational change depends on what teachers do and think - it is as simple and complex as that.' Borko (2004) also asserted that educational change is not likely to take place when teachers are merely viewed as practitioners who are expected to implement the plans of others, implying that failure of curriculum reform is caused by the lack of involvement and lack of ownership for the reform. On the contrary, teachers' ownership of the curricular problem to be solved and their active involvement in the design of a curricular solution are often reported as the main mechanisms to foster the implementation of a curriculum reform. Various scholars indicated the need to involve teachers from the early stages of the curriculum reform processes (e.g., Borko, 2004; Darling-Hammond \& McLaughlin, 1995; Fullan, 2007; Stenhouse, 1975). 
The importance and relevance of teachers' involvement in curriculum development is increasingly becoming apparent when curriculum policy is considered. In the Netherlands, teachers formally and legally have a great deal of autonomy to shape and enact their own (school-specific) curriculum (Kuiper, Van den Akker, Hooghoff, \& Letschert, 2006; Nieveen \& Kuiper, 2012). Schools and teachers have been given 'curricular space' to shape and arrange their so-called school-based curricula (Nieveen, Van den Akker, \& Resink, 2010). As to educational policy in The Netherlands, recent initiatives underlined the importance of making it possible for teachers to become designers of curriculum materials (e.g., Ministerie van Onderwijs, Cultuur en Wetenschap, 2011; Onderwijsraad, 2014; VO-Raad, 2014). They allow teachers to design curriculum materials that take the school's context and its students into account. Studies related to these initiatives report positive findings on teachers' collaboration in curriculum development. While designing, teachers can discuss the essence of the renewal and classroom implementation, which helps to improve teachers' understanding of the reform and fosters their ownership for the reform.

Although teachers in different contexts have been increasingly involved as designers in curriculum reform projects, not all efforts were successful. First attempts were ill-structured and teachers received little support during the process (e.g., Eggleston, 1980; Nieveen et al., 2010; Onderbouw-VO, 2009; Skilbeck, 1984). A major problem was that teachers lacked certain knowledge and skills needed to fulfil the proposed role of designer (Bakah, Voogt, \& Pieters, 2012; Forbes, 2009; Handelzalts, 2009; Nieveen et al., 2010). For the success of their efforts, it does not seem to be enough to count on ownership, active involvement and willingness to cooperate in curriculum development. In order to play a significant role as curriculum designer and to successfully implement the new curriculum materials in their classrooms, teachers need to have specific knowledge and skills, in particular subject matter knowledge, pedagogical content knowledge and curriculum design expertise (Nieveen et al., 2010; Nieveen \& Van der Hoeven, 2011; Schwab, 1973). The various categories of expertise required for designing quality curricula have been comprehensively defined as 'design expertise' (Hardré, 2003; Hardré, Ge, \& Thomas, 2006; Huizinga, 2009; Huizinga, Nieveen, Handelzalts, \& Voogt, 2013; Nieveen \& Van der Hoeven, 2011). Design expertise consist of two components, namely process and generic design expertise and specific design expertise, which includes teachers' expertise in curriculum design (Huizinga, 2009). 
Although some teachers who fulfil the role of designer are expected to have intuitive design expertise, many of them lack this kind of expertise, demonstrated by studies in the USA and The Netherlands (Forbes, 2009; Handelzalts, 2009; Hardré et al., 2006; Kerr, 1981; Nieveen et al., 2010). Therefore, most teachers can be considered novices in curriculum design, and subsequently experience beginner's difficulties while designing curriculum materials (e.g., Ertmer \& Cennamo, 1995; Kerr, 1981; Kirschner, Carr, Van Merriënboer, \& Sloep, 2002). In order to end up with good quality materials and, ultimately, to play a decisive role in curriculum reform, it seems essential to support teachers in their collaborative design process, to help them tackle design challenges and to develop their design expertise (Handelzalts, 2009; Hardré et al., 2006; Nieveen, Handelzalts, Van den Akker, \& Homminga, 2005).

The collaborative design of curriculum materials has been identified as a promising way to foster the design of quality curriculum materials and to enhance classroom implementation (Handelzalts, 2009; Hardré et al., 2006; Fullan, 2007). Furthermore, teacher involvement in collaborative design processes offers opportunities to learn about the design process (Bakah et al., 2012; Voogt et al., 2011).

Recently, professional learning communities as means for teachers' professional development have become more popular and have been proven successful (Desimone, 2009, 2011; Stoll, Bolam, McMahon, Wallace, \& Thomas, 2006). Participation in these communities permits teachers to develop their expertise by sharing ideas and opinions and by reflecting on their practices (Hord, 2004; Little, 1990, 2003; Stoll et al., 2006). A concrete form of a professional learning community aimed at curriculum development can be found in Teacher Design Teams [TDTs], which are teams of at least two teachers who collaboratively (re)design parts of their shared curriculum (Handelzalts, 2009). These teams can be considered design communities in which active learning by collaborative designing is taking place. The activities and discussions in TDTs provide opportunities for developing expertise needed to design and implement the new curriculum materials (Clarke \& Hollingsworth, 2002; Coenders, 2010; Handelzalts, 2009). During TDT meetings, teachers discuss how a pedagogical approach is incorporated in the curriculum materials or exchange their experiences of using the materials in classroom practices. Furthermore, the members of TDTs can identify which actions are needed to further improve the designed curriculum materials. TDTs offer opportunities for teacher learning, especially when supported by an external facilitator and when support is related to teachers' subject matter knowledge, pedagogical content knowledge and curriculum design expertise (e.g., Desimone, 2009; Hoogveld, 2003; Penuel, Fishman, Yamaguchi, \& Gallagher, 2007; Voogt et al., 2011). 
Although working in TDTs is advocated by various scholars (e.g., Bakah et al., 2012; Handelzalts, 2009; Penuel et al., 2007; Simmie, 2007; Voogt et al., 2011), little is actually known with regard to what design and implementation activities and what support offered by an external facilitator to TDTs provide opportunities to develop teachers' design expertise (Handelzalts, 2009; Hardré et al., 2006; Nieveen et al., 2010). In this study, this will be explored in TDTs in schools where teachers work together on the design and implementation of a curriculum reform.

\subsection{AIM OF THE STUDY}

This study focuses on the opportunities TDTs offer to teachers to develop their curriculum design expertise. The study is conducted in the context of a curriculum reform of a school subject. Teams of teachers from the same school intended to design curriculum materials (attuned to the curriculum reform) and implement these within their own classrooms. As discussed before, teachers need, besides subject matter knowledge and pedagogical content knowledge, also curriculum design expertise in order to be able to design quality curriculum materials. To identify what opportunities TDTs offer to develop teachers' curriculum design expertise, it is essential to get a better understanding of teachers' need for support and the actual support offered to TDTs. Identifying beneficial support and design activities may help improve the manner in which future TDTs need to be structured. In addition, various factors can affect teachers' ability to overcome the challenges they experience while creating curriculum materials. By verifying factors that affect this ability it becomes more clear under which conditions TDTs are beneficial in developing teachers' curriculum design expertise.

\subsection{CONCEPTUAL FRAMEWORK}

In this section, the main concepts of the study are clarified. First the concept of curriculum is explained and related to this study (1.3.1). Then, the overall concept of design expertise (1.3.2) and specific design expertise of teachers as designers (1.3.3) are introduced. Finally, the opportunities Teacher Design Teams provide to develop to develop their design expertise is addressed (1.3.4). 


\subsubsection{Curriculum}

A curriculum is a plan for learning (Taba, 1962). Curricula and the corresponding curriculum products can be developed for various levels, namely nano (student level), micro (classroom level), meso (school level), macro (national level) and supra (international level) (Van den Akker, 2003). Guidelines from the supra or macro level affect the curriculum at the school and classroom level. In all levels, a distinction can be made between the intended curriculum (rationale of the curriculum and intentions), the implemented curriculum (interpretation by the teachers and actual teaching and learning process) and the attained curriculum (learning experiences and learning outcomes) (Goodlad, Klein, \& Tye, 1979; Van den Akker, 2003). The transformation from the intended to the attained curriculum can be a long and complex process, in which various stakeholders are involved (e.g., Marsh, Day, Hannay, \& McCutcheon, 1990). While developing the curriculum, decisions have to be made about various components of the curriculum, such as the goals and content, learning activities and materials and resources (Van den Akker, 2003). Van den Akker (2003) pointed out the importance of aligning the components to one another and illustrated the vulnerability of the curriculum by using a spider's web as a metaphor.

In this study, teams of teachers (TDTs) within schools were faced with the implementation of a curriculum reform in their classrooms (please refer to section 1.4 for more information on the renewal). These TDTs consisted of teachers from the same department, who collaboratively renewed a school subject. The reform specifically required TDTs to align the school subject to an international framework developed for teaching and learning the subject according to a new approach (intended curriculum at supra level). During their design process, teachers needed to develop a shared vision and common understanding of how this international framework affects their subject and their teaching (intended/implemented at meso level). Based on this shared vision the teacher teams were to develop lesson materials that could be used in the classrooms (intended/implemented curriculum at micro level). The curriculum materials at this stage include lesson materials for students and assessment rubrics. 


\subsubsection{Design expertise}

It is generally agreed upon that teachers taking up the role of designer need specific knowledge and skills to plan and carry out design processes (Bakah et al., 2012; Brown \& Edelson, 2003; Forbes, 2009; Hardré, 2003; Huizinga, 2009; Richey, Field, \& Foxon, 2001). Although various scholars (e.g., Eggleston, 1980; Marsh et al., 1990) pointed out the importance of such knowledge and skills, the conceptualization and operationalization of the required knowledge and skills covered by this concept differs (see Table 1.1). For identifying relevant knowledge and skills for teachers as designers, insights from prior studies in which teachers fulfilled the role of designers (e.g., Brown \& Edelson, 2003; Forbes, 2009; Handelzalts, 2009) and overviews of professional instructional designers (e.g., Richey et al., 2001; Seels \& Glasgow, 1991) were combined.

Table 1.1 presents an overview of expertise defined for professional designers (Richey et al., 2001) and expertise teachers need in order to fulfil the role of curriculum designer (e.g., Brown \& Edelson, 2003; Forbes, 2009; Hardré, 2003; Hardré et al, 2006), including design activities performed by teachers as curriculum designers (e.g., Richey et al., 2001).

Table 1.1 Definitions addressing design expertise

\begin{tabular}{|c|c|c|c|}
\hline Author(s) & Term & Definition & Research context \\
\hline $\begin{array}{l}\text { Brown \& } \\
\text { Edelson (2003) } \\
\text { Forbes (2009) }\end{array}$ & $\begin{array}{l}\text { pedagogical } \\
\text { design } \\
\text { capacity }\end{array}$ & $\begin{array}{l}\text { Teachers' abilities and competence to } \\
\text { perceive and mobilise both personal } \\
\text { teacher resources (knowledge, beliefs, } \\
\text { identity, and orientations) and } \\
\text { external curriculum resources to craft } \\
\text { instruction and instructional context } \\
\text { in light of instructional goals }\end{array}$ & $\begin{array}{l}\text { Pre-service teachers } \\
\text { who design inquiry } \\
\text { materials during their } \\
\text { course }\end{array}$ \\
\hline $\begin{array}{l}\text { Richey et al. } \\
\text { (2001) }\end{array}$ & $\begin{array}{l}\text { instructional } \\
\text { design } \\
\text { competencies }\end{array}$ & $\begin{array}{l}\text { Competency: A knowledge, skill or } \\
\text { attitude that enables one to } \\
\text { effectively perform the activities of a } \\
\text { given occupation or function so as to } \\
\text { meet the standards expected in } \\
\text { employment } \\
\text { Instructional design is a process most } \\
\text { commonly guided by systematic } \\
\text { design models and principles }\end{array}$ & $\begin{array}{l}\text { Instructional designers } \\
\text { (operationalised per } \\
\text { specialization) }\end{array}$ \\
\hline $\begin{array}{l}\text { Hardré (2003) } \\
\text { Hardré et al. } \\
(2006)\end{array}$ & $\begin{array}{l}\text { design } \\
\text { expertise }\end{array}$ & $\begin{array}{l}\text { Teacher's ability to identify, explain } \\
\text { and discriminate among the } \\
\text { classroom-relevant knowledge } \\
\text { components of the field of } \\
\text { instructional design }\end{array}$ & $\begin{array}{l}\text { Students from two } \\
\text { graduate-level courses } \\
\text { in instructional design } \\
\text { who design } \\
\text { instructional materials }\end{array}$ \\
\hline
\end{tabular}


Teachers' attitudes, although in practice essential for successful curriculum design, were not addressed in this study. Problems teachers encounter during curriculum design processes mainly relate to a lack in teachers' knowledge and skills (e.g., Handelzalts, 2009; Kerr, 1981). Therefore, the definition of Hardré et al. (2006) was taken as a starting point and was adapted to fit to the context of teachers who fulfil the role of designer. This led to the following definition of design expertise: 'the required knowledge and skills to design quality curriculum materials.'

In a prior study, Huizinga (2009) identified the knowledge and skills that teachers as designers need to develop quality curriculum materials. Based on a literature review and expert-validation, he concluded that design expertise consists of generic design and process expertise and specific design expertise. The generic design and process expertise addresses the knowledge and skills required for any type of design process (e.g., collaboration and project management skills). The specific design expertise addresses the knowledge and skills specifically required for developing curricula (e.g., subject matter knowledge and curriculum design expertise). The following seven categories describing teachers' design expertise were identified and validated:

\section{Generic design and process expertise}

1. Intra-personal skills - teachers' personal motivation and ambition to conduct curriculum design. These skills are essential for designers to be willing to create curriculum materials and keep motivated when they are faced with challenges in the design process (Kessels, 2001; Reeves, 2006).

2. Inter-personal skills - teachers' ability to collaborate and communicate during curriculum design. Both collaboration and communication skills are essential, because design processes often have a collaborative nature in which important stakeholders (e.g., colleagues outside the design team) are involved in the decision-making process and need to be informed about the decisions made (Chastain \& Elliot, 2000; Handelzalts, 2009; Kessels \& Plomp, 1999; Peterat, 1993).

3. Process-related skills - teachers' ability to plan and manage design processes. Project management includes the knowledge and skills to coordinate the team activities and to identify the progress of the design process (Crain, Davis, Calkins, \& Gentili, 1995; Lunenberg, 2002; Richey et al., 2001; Seels \& Glasgow, 1991). 
Specific design expertise

4. Subject matter knowledge - teachers' knowledge and skills to keep subject matter knowledge accurate and up-to-date. In order to design curriculum materials that are relevant, consistent, practically usable and effective, teachers are expected to have an accurate and up-to-date understanding of the facts, concepts, procedures and principles of the subject they teach (Davis \& Krajcik, 2005; Marks, 1990). Teachers need to use their subject matter knowledge while designing the curriculum materials (Beneson \& Piggott, 2002; Nieveen \& Van der Hoeven, 2011).

5. Pedagogical content knowledge - teachers' expertise to select, apply and attune (pedagogical) strategies for teaching and learning specific content. For curriculum design, teachers as designers are expected to include their pedagogical repertoire in the designed curriculum materials (Beyer \& Davis, 2012; Coenders, 2010; Van Driel, Beijaard, \& Verloop, 2001). Furthermore, materials (including ICT-applications) need to be selected that suit the pedagogy and the content. Teachers need to determine whether the selected materials should be included in the designed curriculum materials (Barrows \& Kelson, 1993; Koehler \& Mishra, 2008; Shulman, 1986).

6. Curriculum design expertise - teachers' knowledge and skills to conduct curriculum design. It includes teachers' ability to conduct curriculum design activities (e.g., analysis, design and evaluation activities) and to overcome design challenges while designing (Gustafson, 2002; Hardré et al., 2006; Kerr, 1981; Verhagen, Kuiper, \& Plomp, 1999).

7. Curriculum consistency expertise - teachers' ability to design materials that are internally and externally consistent. Whereas internal consistency reflects the logic contingencies of the components of the curriculum (Kessels, 1993; Van den Akker, 2003), external consistency refers to a shared understanding of the content and nature of the curriculum that needs to be designed (Kessels, 1993; Kessels \& Plomp, 1999).

In the current study the emphasis is on teachers' specific design expertise. Teachers as designers need this expertise to cope with design challenges that they might face during the design process. In this study, the categories 'curriculum design expertise' and 'curriculum consistency expertise' were combined in the concept of curriculum design expertise, because it appeared that these categories overlapped. By conducting the analysis, design, development, implementation and evaluation activities it is expected that the designed curriculum materials are 
internally and externally consistent (Kessels \& Plomp, 1999). In the next section, teachers' specific design expertise will be elaborated in-depth.

\subsubsection{Specific design expertise}

The specific design expertise reflects teachers' knowledge and skills in curriculum design. As indicated before, since teachers can be identified as novices in curriculum design, it seems essential to develop their specific design expertise. Teachers' subject matter knowledge and their pedagogical content knowledge were identified to be beneficial for fulfilling the role of designer (e.g., Coenders, 2010; Huizinga, 2009; Schwab, 1973). These will be elaborated first, followed by an elaboration of the additional knowledge and skills teachers as designers need in order to conduct curriculum design processes (curriculum design expertise).

\section{Subject matter knowledge}

The design of quality materials implies that the designed materials are relevant, consistent, practical and effective (e.g., Nieveen, 2009; Nieveen \& Folmer, 2013). Subject matter knowledge, which is represented in the curriculum materials, needs to be accurate, relevant and up-to-date. It is expected that throughout their professional career, teachers apply various strategies to keep their knowledge upto-date, for example by collegial consultation, reading literature and attending conferences (e.g., Brandes \& Seixas, 1998; Davis \& Krajcik, 2005; Nelson \& Orey, 1991; Kessels, 2001). They use their subject matter knowledge when creating the curriculum materials. Teachers need to be able to attune subject matter knowledge $[\mathrm{SMK}]$ to suit the students and the difficulties students have with the subject matter (Angeli \& Valanides, 2009; Kreber \& Cranton, 2000; Marks, 1990; Richey, Klein, \& Nelson, 2004).

\section{Pedagogical content knowledge}

The designed curriculum materials not only need to represent accurate and up-todate subject matter knowledge, but they also need to fit a specific pedagogical approach. The pedagogical approach depends on the rationale (or vision) of the curriculum reform (as indicated in the spider's web of Van den Akker, 2003). The pedagogical approach is reflected in the strategies and corresponding teacher and learning activities, in the materials and resources, in the assessment strategies and so on. Teachers' expertise to select, design and apply strategies and corresponding activities for teaching and learning specific goals and content has been defined as pedagogical content knowledge [PCK] (Shulman, 1986, 1987). Teachers need to 
have a deep understanding of the subjects they teach, the various possible pedagogical approaches and which instructional activities are relevant and effective for their students (Cochran, King, \& De Ruiter, 1991; Marks, 1990; Shulman, 1986; 1987). PCK is an important prerequisite for developing curriculum materials, because teachers' understanding of the pedagogy is reflected in the curriculum materials they select, adapt and/or develop (Barrows \& Kelson, 1993; Brown \& Edelson, 2003; Forbes, 2009; Koehler \& Mishra, 2008; Koehler, Mishra, \& Yayha, 2007; Remillard, 2005; Verloop \& Lowyck, 2003). Therefore, during curriculum reform, teachers' PCK usually needs to be further developed before teachers start designing curriculum materials.

\section{Curriculum design expertise}

The concept of curriculum design expertise is grounded in the phases distinguished in curriculum and instructional design models (e.g., Hardré et al., 2006; Huizinga, 2009; Richey et al., 2001; Seels \& Glasgow, 1991). For each stage of the design model, teachers as designers are expected to have specific knowledge and skills that help them to successfully fulfil the design process and to tackle the challenges they face while designing. Huizinga (2009) identified six aspects of curriculum design expertise that teachers need during curriculum design processes. These aspects are provided in Table 1.2.

Applying a systematic and iterative design approach is beneficial for the quality of the designed curriculum materials (Dick, Carey, \& Carey, 1985; Gustafson, 2002; Visscher-Voerman, 1999). Conducting a systematic curriculum design approach prevents that vital design activities are neglected during the design process. The systematic design approach is not necessarily reflected as a linear design approach, but consists of various iterations of design activities (Gustafson \& Branch, 2002; Visscher-Voerman, 1999; Verhagen et al., 1999). When teachers conduct design processes they usually concentrate on the design of learning activities and curriculum materials (Forbes, 2009; Handelzalts, 2009; Kerr, 1981). Teachers often skip important design activities, because of contextual limitations and teachers' limited curriculum design expertise (Bakah et al., 2012; Handelzalts, 2009; Kerr, 1981), in particular, analysis and evaluation activities, which affects the quality of the designed materials. Consequently, teachers might develop curriculum materials that do not suit the learners or do not reflect the reform (Handelzalts, 2009). To prevent that the curriculum materials lack quality, teachers need to be aware of the importance of analysis, design, development, implementation and evaluation activities and the influence of these activities on the internal and external consistency of the curriculum materials (Kessels \& Plomp, 1999; Verhagen et al., 1999). 
Table 1.2 Relation between the aspects of curriculum design expertise and why it is needed during curriculum design processes

\begin{tabular}{|c|c|}
\hline $\begin{array}{l}\text { Aspect of curriculum design } \\
\text { expertise }\end{array}$ & Needed for \\
\hline $\begin{array}{l}\text { Systematic curriculum design } \\
\text { skills }\end{array}$ & $\begin{array}{l}\text { Conducting a systematic and iterative design process in } \\
\text { which all relevant and important design activities are } \\
\text { included (e.g., Gustafson \& Branch, 2002; Richey et al., 2001; } \\
\text { Visscher-Voerman, 1999). }\end{array}$ \\
\hline $\begin{array}{l}\text { Curriculum decision-making } \\
\text { skills }\end{array}$ & $\begin{array}{l}\text { Underpinning design decisions based on insights from } \\
\text { practice, (scientific) literature or external facilitators (e.g., } \\
\text { Richey et al., 2001). }\end{array}$ \\
\hline $\begin{array}{l}\text { To formulate a problem } \\
\text { statement }\end{array}$ & $\begin{array}{l}\text { Conducting analysis activities (e.g., learner analysis, context } \\
\text { analysis, problem analysis, needs analysis), determining what } \\
\text { problem needs to be solved during the design process and } \\
\text { developing a shared vision and common understanding of } \\
\text { the key concepts of the reform (Handelzalts, 2009; Hord, 2004; } \\
\text { Lunenberg, 2002; Smith \& Ragan, 2005; Stoll et al., 2006). }\end{array}$ \\
\hline Idea generation skills & $\begin{array}{l}\text { Identifying possible solutions to tackle the problem statement } \\
\text { (Handelzalts, 2009; Richey et al., 2001). }\end{array}$ \\
\hline $\begin{array}{l}\text { Implementation management } \\
\text { skills }\end{array}$ & $\begin{array}{l}\text { Planning classroom implementation and fostering the } \\
\text { enactment of the designed curriculum materials (Fullan, 2007; } \\
\text { Tamir, 2004) by developing ownership (Kessels \& Plomp, } \\
\text { 1999), involving relevant stakeholders in the design process } \\
\text { (Penuel et al., 2007) and sharing experiences of classroom } \\
\text { enactment (Simmie, 2007). }\end{array}$ \\
\hline $\begin{array}{l}\text { Formative and summative } \\
\text { evaluation skills }\end{array}$ & $\begin{array}{l}\text { Determining the worth and merit of the curriculum materials } \\
\text { (Scriven, 1991) by formulating evaluation goals, develop } \\
\text { instruments, collecting data, analysing the data and interpreting } \\
\text { the results and improving the curriculum materials (Cochran- } \\
\text { Smith \& Lytle, 2009; Richey et al., 2001; Schildkamp, Poortman, } \\
\text { \& Handelzalts, submitted; Verhagen et al., 1999) }\end{array}$ \\
\hline
\end{tabular}

During all design activities, decisions need to be made that affect the curriculum materials and the design process (Dick et al., 1985; Gustafson \& Branch, 2002; Smith \& Ragan, 2005). Underpinning the decisions made and using insights from various sources is expected to result in well-considered curriculum materials. Teachers as designers use their practical understanding of the classroom, teaching and their students to underpin the design decisions (Forbes, 2009; Handelzalts, 2009). They hardly use insights from (scientific) literature during the design process to improve the quality of the materials or to guide their design process (Handelzalts, 2009). Insights from literature are usually offered by external facilitators, who help to guide the overall design process and offer support (e.g., 
Linder, 2011; Nieveen et al., 2005). To prevent that teachers' misconceptions affect the curriculum materials, teachers need to be informed about relevant and useful scientific and practical insights during the design process.

For guiding the design process, a shared vision of the aim of the design process and expected outcomes is vital (Handelzalts, 2009; Hord, 2004; Smith \& Ragan, 2005). By conducting various analysis activities a shared problem statement has to be formulated. Moreover, the key concepts of the reform need to be clarified, because they guide the design process and are used to determine if the design process is successful (Handelzalts, 2009; Hord, 2004). Previous studies indicate that teachers hardly conduct analysis activities to identify students' needs and students' characteristics and the contextual boundaries (Beyer \& Davis, 2009; Forbes, 2009; Handelzalts, 2009) of the reform in their context. Moreover, at the start of the design process, teachers as designers tend to skip the development of a shared vision and understanding (e.g., Coenders, 2010; Handelzalts, 2009). Given the importance of a shared vision, because it would be leading for the remaining part of the design process, teachers need to improve their understanding of conducting analysis activities and developing a shared vision.

An important step to tackle the identified problem is to identify possible solutions (Richey et al., 2001), for instance by using brainstorming techniques (e.g., Christensen \& Osguthorpe, 2004; Crain et al., 1995). Prior studies in which teachers fulfilled the role of designer demonstrated that teachers often start designing by generating various ideas about the curriculum materials (Coenders, 2010). Teachers understanding of the existing materials, previous efforts to tackle (similar) problems and the curriculum reform help teachers to generate ideas and to determine what materials need to be developed. While generating ideas, teachers compare the ideas to one-another and the best ideas are materialised and used for developing the curriculum materials (Handelzalts, 2009; Kerr, 1981).

Classroom implementation of the designed materials is a key element of the design process (Fullan, 2007; Richey et al., 2001; Verhagen et al., 1999) because this is how the reform is enacted in classroom practice. Prior studies demonstrated that the implementation of the new curriculum materials is not self-evident. Teachers as designers need to discuss the teacher role, teacher-student interaction and other practical concerns with colleagues outside the TDT (Handelzalts, 2009; Penuel et al., 2007). Handelzalts (2009) argued that this hardly happens, which affects classroom implementation. To prevent that other relevant stakeholders (e.g., school's management and colleagues outside the TDT) lack ownership for the 
designed curriculum materials, teachers as designers need to understand the importance of and be able to involve stakeholders in the design process.

To assess the quality and the worth and merit of the designed curriculum materials, designers need to conduct formative and summative evaluations (Nieveen, 2009; Scriven, 1991; Verhagen et al., 1999). Formative evaluations help to improve the quality of the designed curriculum materials, because the outcomes of the evaluations are used to further improve the materials before they are implemented in classroom practice. Summative evaluations often emphasise on student learning and help to inform whether the materials are beneficial for students. These outcomes are also used to improve or redesign the curriculum materials. Previous studies show that teachers do not plan and structure evaluations (Handelzalts, 2009; Kerr, 1981), which can be the result of having little understanding of assessing the quality of curriculum materials (Handelzalts, 2009; Nieveen et al., 2005). To prevent that materials are implemented that do not suit the context, do not foster student learning and do not represent the reform, teachers need to improve their understanding of conducting structured evaluations.

\subsubsection{Developing curriculum design expertise through TDTs}

For the success of curriculum reform, it seems essential to assist teachers in developing their curriculum design expertise (e.g., Beyer \& Davis, 2009, 2012; Handelzalts, 2009; Hardré et al., 2006; Hoogveld, 2003; Kerr, 1981; Nieveen et al., 2010). This can happen via various ways of capacity building (Loucks-Horsley, Hewson, Love, \& Stiles, 1998). Desimone (2011), summarizing research on teachers' professional development, distinguished a number of effective components of professional development, two of which are especially relevant for developing teachers' curriculum design expertise: Active learning (opportunities to develop knowledge through activities such as observing, receiving feedback or presenting progress to others) and collaborative participation (participating together with fellow teachers from the same grade, subject, or school in a learning community). Participation in a design community, such as a TDT, in which active learning takes place by collaboratively designing curriculum materials, meets these conditions (Coenders, 2010; Handelzalts, 2009; Simmie, 2007; Voogt et al., 2011). Therefore, working in professional learning communities or teacher communities provide opportunities to share and develop new expertise (Pareja Roblin, Ormel, McKenney, Voogt, \& Pieters, 2014), and is assumed to be beneficial for teachers to develop their curriculum design expertise, for instance, by discussing the design and implementation of the curriculum reform in classroom 
practice. These discussions help to better understand the reform and conducting curriculum design (Voogt et al., 2011). In addition to designing, teachers are expected to use the curriculum materials in their classroom practices. Classroom implementation offers a prime opportunity to experience the reform and to reflect on its enactment in practice (Anto, 2013; Clarke \& Hollingsworth, 2002; Lieberman \& Pointer Mace, 2008). Teacher involvement in collaborative curriculum design offers opportunities for teachers to develop their curriculum design expertise, especially when support is offered to the teachers while designing (Penuel et al., 2007; Voogt et al., 2011).

Ideally, support offered to TDTs is accustomed to teachers' existing expertise, their experience in curriculum design, the challenges they encounter in the design process and the expected outcomes of the design process (Desimone, 2011; Garet, Porter, Desimone, Birman, \& Yoon, 2001; Loucks-Horsley et al., 1998). Teachers' individual existing expertise and experiences might differ within the team, which makes the support process and the development of curriculum design expertise a complex process (Hardré et al., 2006).

Previous studies indicated the importance of supporting TDTs by an external facilitator (e.g., Linder, 2011; Nieveen et al., 2005; Patton, Parker \& Neutzling, 2012; Velthuis, 2014; Voogt et al., 2011). External facilitators can offer new insights about the design process and the reform, help TDT to conduct activities and help to foster the reflection activities. The external facilitator can apply two styles of support (Linder, 2011; Nieveen et al., 2005). First, facilitators can apply proactive support. This facilitation style requires that facilitators help to structure the design process before design activities are conducted. The support is predesigned and aligned with the articulated need for support. Second, facilitators can offer reactive support. This support is aligned to the progress of the design team and is expected to be offered just-in-time, since new insights are offered when teachers face design challenges. Finally, combing the two styles can be identified as a way to facilitate teachers' professional development (Linder, 2011).

\subsection{CONTEXT OF THIS STUDY}

This study was conducted in the context of a national non-mandatory curriculum reform. In the Dutch national context schools for secondary education can decide whether or not to integrate the Common European Framework of Reference for languages (CEFR) in their foreign language curriculum. The CEFR-project offered 
a prime opportunity to examine how teachers' curriculum design expertise can be developed. Teams of teachers were faced with the implementation of a curriculum reform, which they had to adapt and fit to the school's context. During the CEFR-project the responsibility of developing the new foreign language curricula rested on the shoulders of teams of teachers.

CEFR was introduced in 2001 as a way to align the language curricula of the various European countries with each other. This alignment was expected to create opportunities to compare language curricula and to make it easier to identify what the language knowledge and skills were of students (Council of Europe, 2001).

In CEFR specific knowledge and skills are defined for six proficiency levels (see Figure 1.1). Each level refers to a specific language user. The breakthrough level (A1) is the lowest and the mastery level (C2) the highest level of proficiency. The specific knowledge and skills are described in can-do statements. Each can-do statement operationalises what is expected from the learner (can) in terms of how the language is applied in a specific context $(d o)$.

\begin{tabular}{|c|c|c|}
\hline \multicolumn{3}{|c|}{ User's level } \\
\hline \multirow{2}{*}{$\begin{array}{c}\text { A } \\
\text { Basic }\end{array}$} & $\mathrm{A} 1$ & Breakthrough \\
\hline & A2 & Waystage \\
\hline \multirow{2}{*}{$\begin{array}{c}\text { B } \\
\text { Independent }\end{array}$} & B1 & Threshold \\
\hline & B2 & Vantage \\
\hline \multirow{2}{*}{$\underset{\text { Proficient }}{\mathrm{C}}$} & C1 & Effective Operational Proficiency \\
\hline & C2 & Mastery \\
\hline
\end{tabular}

Figure 1.1 Overview of the language levels as described in CEFR (Centre Européen de Language Francaise, n.d.)

In contrast to the common strategies applied in teaching and learning foreign languages with an emphasis on grammatical correctness and students' writing and reading skills, the emphasis in CEFR is on how learners apply the foreign language for communication with other foreign language users. For each level and each language skill (e.g., listening or reading) a description is provided. At the lower CEFR-levels (A1/A2) students are allowed to make grammatical and spellings mistakes, whereas at the higher CEFR-levels (C1/C2) grammatical and spelling mistakes are no longer allowed. In contrast to teachers' current (or common) practices, all five language skills (listening, reading, spoken production, spoken interaction and writing) are addressed equally in CEFR-based lessons. 
Consequently, teachers are required to apply new strategies for teaching in their lessons. The new strategies offer students the responsibility to plan and enact their own learning process. For teachers these new strategies imply that instead of direct instruction on grammar and providing students with exercises, teachers are expected to coach their students in working with language tasks.

Language tasks take place in a (simulated) authentic context. These tasks aim to let students learn specific language skills by incorporating can-do statements. An example of a language tasks is that the student lost his/her suitcase at the airfield and needs to identify which steps to take to claim the suitcase. While working on this particular task, the student needs to read the signs at the airport, to have a conversation with a desk attendant, to describe the suitcase and to explain when it was lost, and to fill in a form to claim the suitcase. All language skills are used in solving the language task. In the current study, teacher teams developed language tasks for their students.

In addition to the language tasks the teams also developed other curriculum materials using the CEFR-framework, such as assessment rubrics and vision documents. Assessment rubrics were used to assess the language skills of learners. For example, to evaluate the conversation between two students, the assessment rubric operationalised the spoken production skill by using the can-do statements of the language skills at a particular language level (e.g., A2-level). Vision documents were developed as well to describe how the teams want to implement CEFR in their classroom practices. Those documents discuss the role of the teacher, the student-teacher interaction, the curriculum materials and student assessment. After designing these materials, teachers were expected to implement the newly designed materials in their classroom practices.

During a two-year project, 15 TDTs received support from the Netherlands Institute for Curriculum Development. The TDTs designed curriculum materials to be used within their own school and for collegial purpose. At the start of the project, the TDTs differed in their prior knowledge about CEFR and to what extent the foreign language teachers already implemented CEFR in practice.

Each TDT consisted of at least two teachers and a maximum of 16 teachers. In some cases, not all language teachers in a school were involved in the design process. All TDTs received tailored support that was aligned with their articulated need for support and their prior knowledge regarding CEFR and curriculum design. All substudies, except sub-study 1, were carried out as part of the CEFR-project. 


\subsection{RESEARCH DESIGN}

\subsubsection{Research questions}

The study was set out to identify opportunities TDTs provide to develop teachers' curriculum design expertise. The study was conducted in the context of TDTs within schools which redesigned a school subject. The opportunities that are provided by teacher involvement in TDTs can be the result of the design activities of the TDT and/or the support activities as offered by external facilitators. The main research question that guided this study was:

What opportunities do TDTs provide for teachers to develop curriculum design expertise?

In order to answer the main research question, four sub-studies were conducted. Each sub-study was guided by a research question:

1. What are TDTs' needs for support during collaborative design of lesson series?

2. What design and support activities in TDTs do foster the development of teachers' curriculum design expertise?

3. What implementation and evaluation activities during the design of a new curriculum do provide opportunities for enhancing teachers' curriculum design expertise?

4. Which factors (personal, team and management) affect teachers' ability to tackle design challenges over time?

\subsubsection{Research methods}

For answering the overall research question a mixed method approach was applied (Leech \& Onwuegbuzie, 2009). Qualitative data were collected through semi-structured interviews, observations of the design and support meetings, classroom lesson observations, field notes and the curricular products the teams produced. All instruments were discussed within the research team before they were used for data collection. In the sub-studies various data sources were used for data triangulation (Yin, 2003). Quantitative methods were employed through valid and reliable questionnaires, which were adapted from existing questionnaires addressing design expertise (Hardré et al., 2006; Huizinga, 2009) and (Technological)PCK (Schmidt, Baran, Thompson, Koehler, Mishra, \& Shin, 2009). Furthermore, new scales were developed and validated to answer the specific research questions. The first three research questions (sub-study 1-3) were 
answered using a qualitative approach to identify the design and support activities that help to develop teachers' curriculum design expertise. The fourth research question was answered using a quantitative approach to empirically verify factors affecting teachers' ability to tackle design challenges.

In the first sub-study a qualitative cross-sectional approach was used to reconstruct the design process as experienced by six teachers and six facilitators. The respondents were selected using a purposeful sampling technique (Patton, 1987). Each respondent was interviewed using a semi-structured interview guide that was adapted from Huizinga's study (2009). The interview addressed the design process, the design problems that occurred, how teachers and facilitators overcame these problems and what support was offered. Transcriptions and summaries were made and used during data analysis. The data was coded using an iterative coding process in which first deductive coding was applied, followed by inductive coding.

A qualitative case study approach was used in the second sub-study to identify the activities that help to develop teachers' curriculum design expertise (Yin, 2003). Two teams from two different schools who were involved in the CEFRproject (see 1.4) were followed. One team consisted of five foreign language teachers, the other of sixteen teachers. The unit of analysis is the teachers within the TDTs. For answering the main research question five instruments and one artefact were used. These five instruments were (1) a semi-structured interview guide to capture the expectations and need for support at the start of the project, (2) an observation schedule to capture the design and support activities, teachers' reactions with the activities, the interaction between the TDT and the facilitator and the contextual boundaries, (3) contact summary sheets addressing additional experiences as articulated by teachers and facilitators during informal moments, (4) a semi-structured interview guide to be used with the facilitator addressing the support process and (5) the storyline method (Beijaard, Van Driel, \& Verloop, 1999) to let teachers reflect on the experienced process. The artefact was the 'email traffic' between the coordinator of the TDT and the facilitator. All data were analysed using 'a priori' coding (Strauss \& Corbin, 1998).

In the third sub-study, which also took place within the CEFR-project (see 1.4), a case study approach was applied to identify the implementation and evaluation activities, which provided opportunities to enhance teachers' curriculum design expertise. The design process of three TDTs who received support from an external facilitator was analysed. The TDTs consisted of five, six and sixteen 
foreign language teachers. The unit of analysis was the teachers within the TDTs. Five instruments and one artefact were used to answer the main research questions. These instruments were (1) storyline method (Beijaard et al., 1999) to capture teachers' experiences of the implementation and evaluation activities, (2) observation checklist for TDT meetings addressing the conducted activities during TDT meetings, (3) semi-structured interview with the facilitator addressing the characteristics of the support offered to the TDT, (4) observation checklist for classroom observation addressing the lesson activities, the teacher role and students-teacher interactions and (5) semi-structured interview with the teachers about the observed lesson and their experiences and the need for support. The artefact consists of the language tasks used during the observed lessons. All data were analysed using 'a priori' coding (Strauss \& Corbin, 1998).

In the fourth sub-study a longitudinal multilevel approach was used to identify the factors that influence teachers' ability to tackle design challenges. During the two-year CEFR-project, the respondents filled in a questionnaire addressing their perceptions of their skills in tackling design challenges (Hardré et al., 2006), personal factors (Huizinga, 2009; Schmidt et al., 2009), team factors (Akomaning, 2012; Alayyar, 2011) and management support factors. The questionnaire was administered three times during the CEFR-project: at the start, after one year and at the end of the project. The data were analysed by applying a stepwise approach to construct the multilevel model and to identify which and how factors influence teachers' ability to tackle design challenges. 


\subsection{OVERVIEW OF THE DISSERTATION}

The remainder of the dissertation subsequently covers the four sub-studies. The first study (chapter 2) examined teachers' need for support during collaborative design projects from the perspective of teachers and facilitators.

The second study (chapter 3) focused on the design and support activities of two TDTs that aimed to develop teachers' design expertise.

The third study (chapter 4) investigated the implementation and evaluation activities of three TDTs and its members. In addition, teachers' experiences with these activities are presented.

The fourth study (chapter 5) empirically validated which and to what extent personal, team, and management factors influence teachers' perceived ability to tackle design challenges.

Finally, chapter 6 provides an overview of the whole study and summarises the results of the four sub-studies. This chapter discusses the research approach and the outcomes of the study. Furthermore, the sixth chapter ends with recommendations for practice and research. 


\section{CHAPTER $2^{*}$ \\ Teacher involvement in curriculum design: Need for support to enhance teachers' curriculum design expertise}

Teacher involvement in curriculum design has a long tradition. However, although it fosters implementation of curriculum reforms, teachers encounter various problems while designing related to conditions set for the design process, and lack the knowledge and skills needed to enact collaborative design processes. Providing support to enhance teachers' design expertise is essential, since most teachers are novice designers. However, little is known about the nature of the support offered to improve teachers' design expertise. In this explorative study, six teachers and six facilitators offering support reflected on an enacted design process, the problems they experienced and the support offered. The findings indicate gaps in teachers' design expertise related to three domains (1) curriculum design expertise, (2) pedagogical content knowledge and (3) curricular consistency expertise. The outcomes of this study illustrate the importance of supporting teachers as designers during the design process and enhancing teachers' design expertise. By offering (tailored) support to teachers, the enacted design process and the quality of the design materials are expected to improve.

\subsection{INTRODUCTION}

The success of curriculum reforms largely rests on the shoulders of teachers, since they are the ones who put reform ideas into practice. Successful implementation

This chapter is based on the published article: Huizinga, T., Handelzalts, A., Nieveen, N., \& Voogt, J. M. (2014). Teacher involvement in curriculum design: Need for support to enhance teachers' design expertise. Journal of Curriculum Studies, 46(1), 33-57. 
of reforms depends on teachers' ownership of and their knowledge about reform ideas (Handelzalts, 2009; Kirk \& MacDonald, 2010; McKinney \& Westbury, 1975). Involving teachers from the early stages of curriculum design fosters ownership (e.g., Bakah et al., 2012; Carlgren, 1999; Handelzalts, 2009). The need to involve teachers in curriculum design was realised after failures to implement teacherproof curricula during curriculum reforms in the 1940-1970s (McKinney \& Westbury, 1975; Stenhouse, 1975). Since the mid-seventies scholars (e.g., Green, 1980; Stenhouse, 1975) have discussed the importance of involving teachers in the design process, to provide teachers with 'the opportunity to experience the practical alternatives [and] to make their choices' (Green, 1980, p. 7). It resulted in (schoolbased) curriculum development projects in which teachers fulfilled the designer role (Eggleston, 1980; Skilbeck, 1984). However, these early efforts were poorly supported and structured and teachers lacked the knowledge and skills to enact the design processes (Eggleston, 1980; Walker, 1975). It was expected that by inviting teachers to collaborate in teams during the design process, knowledge and skill-related limitations could be dealt with (e.g., Craig, 2009; Crow \& Pounder, 2000; Parke \& Coble, 1997). Collaboration creates opportunities to exchange experiences and expertise (Handelzalts, 2009; Havnes, 2009; Peterat, 1993; Walker, 1975). Moreover, a shared operational understanding of the curriculum reform and its implications might help to create ownership, and a more realistic implementation strategy (e.g., Elizondo-Montemayor, HernándezEscobar, Ayala-Aguirre, \& Aguilar, 2008).

Despite the advantages of designing curricula in teacher teams, further referred to as 'Teacher Design Teams' (TDTs), some challenges still exist. Next to practical challenges (e.g., limited time) and dealing with the variation in expectations within the team, teachers in TDTs often lack design expertise (Bakah et al., 2012; Handelzalts, 2009; Havnes, 2009; Vescio, Ross, \& Adams, 2008). A lack of design expertise affects the enacted design process and eventually the quality of the designed curricula (Hardré et al., 2006). In order to reduce design expertiserelated problems support is often offered to TDTs (e.g., Bakah et al., 2012; Cumming, 2011). Many studies report about support geared towards developing teachers' subject matter knowledge and pedagogical content knowledge (e.g., Cumming, 2011; Da Ponte, 2012), whereas only a few studies pay attention to the support to increase teachers' design expertise (e.g., Hoogveld, 2003). Since design expertise is crucial for enacting successful design processes, insights into teams' difficulties in curriculum design are required. Combined with articulated needs for support, such insights can be used for designing quality support for TDTs. 
The Dutch context offers a prime opportunity to explicitly study TDTs' difficulties in designing curricula and their needs for support related to design expertise. In 2006, new attainment targets were introduced for lower secondary education in the Netherlands (12-14-year olds). The formulation of the 58 attainment targets was at a very generic level. It was expected that these would be operationalised and adapted at the school level. Approximately $60 \%$ of all schools in lower secondary education gave teacher teams a key role in the (re)design of their curriculum (Onderbouw-VO, 2009). TDTs had to make decisions about what and how content was offered to their learners, which resulted in distinct courses and/or interdisciplinary courses (Onderbouw-VO, 2009).

The purpose of this study was to identify the needs of and support for TDTs to develop design expertise required to design lesson series for interdisciplinary courses. In this study, lesson series refer to a series of related lessons about the same topic of theme. Curriculum materials, such as lesson series, represent the operationalised curriculum reform and, therefore, play an important role during the design of curriculum reforms (Thijs \& Van den Akker, 2009). The question that guided this study was What are TDTs' needs for support during collaborative design of lesson series? In answering this question specific attention was paid to teachers' curriculum design expertise needed to enact the design process. In this study, teachers' need for support to enhance teachers' curriculum design expertise was investigated from two perspectives. First, the knowledge and skillsrelated problems teachers experience while designing indicate which support is needed. Second, support offered to TDTs also provides information about required support for TDTs while designing. Therefore, the main question was divided into two sub-questions, namely:

1. Which problems related to a lack in design expertise do TDTs experience when they collaboratively design lesson series?

2. What support do TDTs receive to acquire the design expertise required to collaboratively design lesson series?

\subsection{DEFINING TEACHERS' DESIGN EXPERTISE}

To be able to identify the support that is needed to enhance teachers' design expertise, we first elaborate on what design expertise is. The expertise required to enact curriculum design has been described by various scholars (e.g., Forbes, 
2009; Hardré, 2003; Hardré et al., 2006; Huizinga, 2009; Nieveen \& Van der Hoeven, 2011, Richey et al., 2001; Seels \& Glasgow, 1991). They use different labels to describe elements of the same concept, including curriculum design competencies (Huizinga, 2009, Seels \& Glasgow, 1991), instructional design competencies (Richey et al., 2001) and design expertise (Hardré, 2003; Hardré et al. 2006). In this study, the term design expertise is used. Design expertise consists of the knowledge and skills to enact a design process. It prescribes analysis, design, development, implementation and evaluation skills (e.g., Eggleston, 1980, Richey et al., 2001; Seels \& Glasgow, 1991). However, teachers are not only expected to be able to enact the design process, but as Schwab (in Ben-Peretz, 1990) points out, they are also required to have substantial knowledge and skills such as subject matter knowledge and insights into the learners, the teachers and the context.

Based on a literature review, Huizinga (2009) developed an overview of the design expertise teachers need in order to be able to design lesson series. Two types of design expertise were distinguished, namely generic design and process expertise and specific design expertise. Generic design and process expertise refers to knowledge and skills for enacting design processes in general, while specific design expertise refers to the knowledge and skills required for developing curricula (in this case lesson series). Both types of design expertise are required in order to successfully enact a design process. Figure 2.1 provides the overview of design expertise required to design curricula. In this study, the focus is on the specific design expertise, since previous studies indicate that most knowledge and skills-related problems relate to the process of curriculum design (e.g., Handelzalts, 2009; Hoogveld, 2003). Therefore, this study focuses on identifying the support needed to develop teachers' knowledge and skills in specific design expertise, that is, curriculum design expertise, subject matter knowledge, pedagogical content knowledge and curriculum consistency expertise. The specific knowledge and skills of these four categories will be described in the next section. 


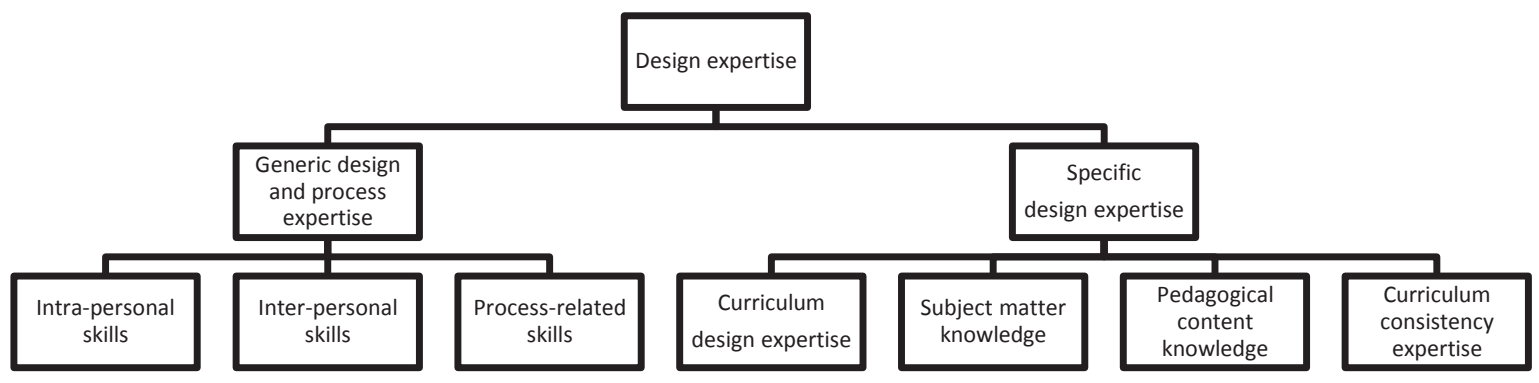

Figure 2.1 Teachers' design expertise overview (Huizinga, 2009)

\subsubsection{Curriculum design expertise}

The knowledge and skills required to enact curriculum design are addressed as curriculum design expertise (Dick et al., 1985; Gustafson \& Branch, 2002; Hardré, 2003; Huizinga, 2009; Lunenberg, 2002; Richey et al., 2001; Seels \& Glasgow, 1991). Curriculum design consists of analysis, design, development, implementation and evaluation activities, which are operationalised in specific tactics. Six types of knowledge and skills, based on activities in existing curriculum and instructional design models, are identified as relevant for teachers for enacting design processes (Huizinga, 2009):

1. Knowledge and skills to formulate a problem statement

2. Idea generation skills

3. Systematic curriculum design skills

4. Formative and summative evaluation skills

5. Curricular decisions-making skills

6. Implementation management skills

Design processes usually start with determining what is being designed. Therefore, teachers as designers are expected to formulate the aim of the project and identify the problem that needs to be tackled (Crain et al., 1995; Lunenberg, 2002; Richey et al., 2001). Furthermore, various ideas have to be generated in order to tackle the identified problem (Crain et al., 1995). During the design process itself teachers are expected to systematically apply tactics to tackle the problem, by making well-founded decisions (based on insights from theory and practice), evaluating the relevancy, consistency, practicality and effectiveness of the curriculum materials (Thijs \& Van den Akker, 2009) and by implementing the curriculum materials in practice (Gustafson, 2002; Kerr, 1981; Kessels, 1999; Lunenberg, 2002; Richey et al., 2001; Seels \& Glasgow, 1991). 


\subsubsection{Subject matter knowledge}

Curriculum materials are expected to represent accurate, relevant and up-to- date insights of the subject matter knowledge. Therefore, teachers as designers should have sufficient knowledge about the course they offer and enact strategies to keep this knowledge up-to-date (Brandes \& Seixas, 1998; Davis \& Krajcik, 2005; Nelson \& Orey, 1991; Richards, 1991). Two types of knowledge and skills related to subject matter knowledge for designing curriculum materials are identified by Huizinga (2009) as relevant for teachers as designers, namely:

1. Knowledge and skills to keep subject matter knowledge up-to-date

2. Knowledge and skills to gain insights into learners' subject matter knowledge difficulties

Teachers apply various strategies to keep their subject matter knowledge accurate and up-to-date, for instance, by collegial consultation, reading professional and/or scientific literature and attending conferences (Huizinga, 2009; Kessels, 2001). Furthermore, teachers are expected to apply this newly acquired knowledge, when relevant, to curriculum materials. In addition to keeping the subject matter knowledge up-to-date, teachers as designers have to become familiar with the difficulties learners have regarding the subject matter knowledge and why learners experience these difficulties (Angeli \& Valanides, 2009; Kreber \& Cranton, 2000; Marks, 1990; Richey et al., 2004). These insights can be used to design materials that effectively support learners in their learning process.

\subsubsection{Pedagogical content knowledge}

Including accurate and up-to-date subject matter knowledge in curriculum materials is not necessarily sufficient to foster the learning process. Therefore, teachers as designers need to decide which approaches to teaching and learning to incorporate in the materials. Shulman $(1986$, p. 9) defined this as pedagogical content knowledge, 'which goes beyond knowledge of subject matter per se to the dimension of subject matter knowledge for teaching'. Three types of knowledge and skills are distinguished for teachers as designers, namely:

1. Pedagogical repertoire

2. Material selection skills

3. ICT selection skills

The pedagogical repertoire addresses teachers' knowledge and skills to select, apply and include relevant pedagogical strategies to offer the subject matter (Cochran et al., 1991; Marks, 1990; Shulman, 1986, 1987), which is used to select 
appropriate materials which represent the course-specific pedagogy (Barrows \& Kelson, 1993; Verloop \& Lowyck, 2003). Furthermore, teachers as designers are expected to determine whether the use of ICT is beneficial for offering the subject matter and to select and integrate appropriate ICT-based materials in the lesson series they are designing (e.g., Angeli \& Valanides, 2009; Koehler et al., 2007).

\subsubsection{Curriculum consistency expertise}

During the design process, teachers need to design materials which are consistent. The consistency of curricula refers to internal consistency and external consistency (Kessels, 1999). Two types of specific knowledge and skills are distinguished in order to develop consistent curricula:

1. Knowledge and skills to create internally consistent curricula

2. Knowledge and skills to create externally consistent curricula Internal curriculum consistency describes the balance and coherence of curriculum elements (e.g., as described by Van den Akker. 2003) and the alignment of the curriculum with the school's vision, their students and demands from society. Teachers as designers should be able to create materials which are well balanced and well-aligned. External curriculum consistency concerns the coherence of perceptions of the involved teachers and relevant stakeholders (e.g., school's management and non-involved teachers) on what the problem is and how to tackle it (Kessels, 1999). External consistency is achieved by applying a relational approach during the process, which implies involving teachers and relevant stakeholders during the early stages of the design process and, therefore, revealing their perceptions of the expected outcomes and how this can be achieved (Handelzalts, 2009; Hord, 2004; Kessels, 1999).

\subsection{SUPPORT TO ENHANCE TEACHERS' DESIGN EXPERTISE}

Support of teachers during curriculum design aims to update teachers' subject matter knowledge, teachers' (technological) pedagogical content knowledge, their curriculum design expertise and their understanding of the particular reform (Bakah et al., 2012, Nieveen et al., 2005; Odenthal 2003; Stenhouse, 1975). However, how to support teachers is less clear, or as Nieveen et al. (2005, p. 22) indicated 'there is no single best way in the innovation process'. This raised a dilemma for facilitators on how to support the development of design expertise in 
TDTs. However, aligning teachers' and facilitators' preferences for support is vital, since it prevents a difference in expectations of the role of the facilitators (Nieveen et al., 2005; Odenthal, 2003). This role depends on the aim of the support, team size and contextual limitations (Garet et al., 2001; Hardré et al., 2006; Loucks-Horsley et al., 1998).

Two strategies for supporting TDTs can be distinguished. First, support, which is part of the team's design process, is offered just-in time and is context specific. This strategy provides opportunities to offer meaningful support to TDTs (Loucks-Horsley et al., 1998), since teachers can determine the relevance and usefulness of the support offered for their design process (Desimone, 2009). Second, support in the form of specific workshops or training sessions to foster teachers' subject matter knowledge, pedagogical content knowledge and/or curriculum design expertise (Bakah et al., 2012; Garet et al., 2001; Hardré et al., 2006; Nieveen et al., 2005). In this scenario, workshops and training sessions are offered with specific predefined aims or learning goals. Since such support is offered in various contexts and is evaluated, the quality and effectiveness of the support is determined and improved before it is offered to new TDTs (LoucksHorsley et al., 1998). However, the effect of this approach has been questioned because teachers cannot directly apply the newly acquired knowledge and skills in practice. Therefore, Lumpe (2007) recommends organizing workshops and specific training sessions as an integral part of just-in-time support.

Facilitators play a crucial role in support offered to design teams. Facilitators can offer proactive and reactive support (Nieveen et al., 2005). When offering proactive support, facilitators help steer the team during the design process (e.g., outlining the process) and make sure that teachers do not skip important design activities (e.g., conducting evaluations). In contrast, when offering reactive support, facilitators follow the team's enacted design process and react on the decisions made and make sure that all important design activities are enacted. Both during reactive and proactive support facilitators determine the support based on the articulated needs for support by the teams. Given the various expectations of the support and preferences of teachers within teams, balancing proactive and reactive support seems essential for the design process (Nieveen et al., 2005; Odenthal 2003). 


\subsection{MethodS}

The aim of this study was to identify TDTs' needs for support to increase their design expertise by answering the research questions as stated at the end of the introduction section. Both teachers and facilitators were interviewed on the enacted design process of locally designed lesson series. This design process took place within the context of a large-scale curriculum reform. Interviews were conducted to explore teachers' design expertise and the provided external support while designing. A qualitative approach was applied to reconstruct the design process allowing for additional questions regarding the design process and the corresponding need for support. The study can be characterised as a cross-sectional qualitative study, since teachers' needs for support were described from two perspectives (teachers and facilitators). Their perspectives were analysed and compared in order to triangulate the data (Patton, 1987).

\subsubsection{Respondents}

Purposeful samples of six teachers and six facilitators were selected (Patton, 1987). A two-stage process was applied to select the teachers. First, schools were selected which offered interdisciplinary courses. Second, within the selected schools, teachers who had experience with designing course materials for these interdisciplinary courses were approached. Table 2.1 shows the characteristics of the interviewed teachers, the aim of their design process and the received support during the design process.

For selecting the facilitator, a similar two-stage process was applied. First, six organizations which offer support to TDTs were selected to participate in this study. Second, within each organization, one facilitator was selected based on the experience of supporting TDTs who designed interdisciplinary courses. The selected facilitators did not offer support to the selected teachers, but were involved in similar projects in order to get a broader picture of the need for support. Table 2.2 shows the facilitators' characteristics and the key characteristics of the TDTs they supported and of the support itself. 
Table 2.1 Characteristics of the teachers

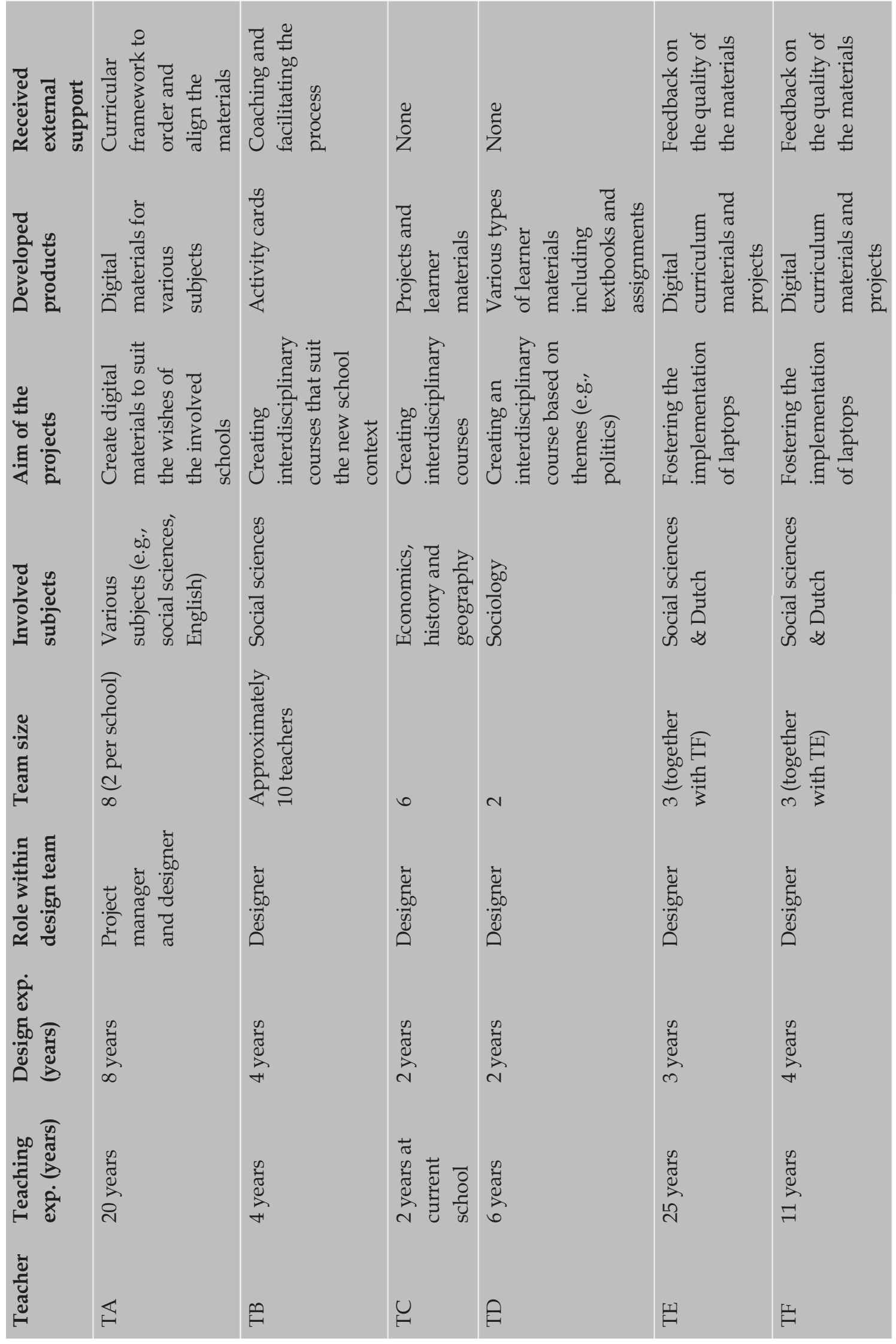


Table 2.2 Characteristics of the facilitators

\begin{tabular}{|c|c|c|c|c|c|}
\hline Facilitator & $\begin{array}{l}\text { Experience } \\
\text { as } \\
\text { facilitator } \\
\text { (years) }\end{array}$ & $\begin{array}{l}\text { Size of the } \\
\text { team that } \\
\text { was } \\
\text { supported }\end{array}$ & $\begin{array}{l}\text { Involved } \\
\text { subjects }\end{array}$ & $\begin{array}{l}\text { Aim of the } \\
\text { supported } \\
\text { project }\end{array}$ & $\begin{array}{l}\text { Developed } \\
\text { materials by the } \\
\text { teachers }\end{array}$ \\
\hline SA & 12 years & 3 & $\begin{array}{l}\text { Geography and } \\
\text { history }\end{array}$ & $\begin{array}{l}\text { Creating and } \\
\text { implementing } \\
\text { interdisciplinary } \\
\text { courses }\end{array}$ & $\begin{array}{l}\text { Interdisciplinary } \\
\text { projects and } \\
\text { learner materials }\end{array}$ \\
\hline SB & 10 years & 30 & Unknown & $\begin{array}{l}\text { Implementing } \\
\text { interdisciplinary } \\
\text { courses and new } \\
\text { pedagogies }\end{array}$ & $\begin{array}{l}\text { Experience with } \\
\text { new pedagogical } \\
\text { insights }\end{array}$ \\
\hline SC & 1.5 years & $\begin{array}{l}\text { All } \\
\text { teachers of } \\
\text { one school }\end{array}$ & $\begin{array}{l}\text { Social sciences } \\
\text { and other } \\
\text { interdisciplinary } \\
\text { courses }\end{array}$ & $\begin{array}{l}\text { Implementing } \\
\text { culture-oriented } \\
\text { education (COE) } \\
\text { for all courses }\end{array}$ & $\begin{array}{l}\text { Learner } \\
\text { materials that } \\
\text { suited the COE } \\
\text { vision }\end{array}$ \\
\hline SD & 9 years & $\begin{array}{l}\text { All } \\
\text { teachers of } \\
\text { social } \\
\text { sciences }\end{array}$ & $\begin{array}{l}\text { Geography, } \\
\text { history and } \\
\text { economics }\end{array}$ & $\begin{array}{l}\text { Implementing } \\
\text { four } \\
\text { interdisciplinary } \\
\text { courses, focus on } \\
\text { social sciences }\end{array}$ & $\begin{array}{l}\text { Activity cards } \\
\text { (learner tasks) }\end{array}$ \\
\hline SE & 3 years & n.a. & n.a. & $\begin{array}{l}\text { Development of } \\
\text { online repository } \\
\text { for curriculum } \\
\text { materials }\end{array}$ & $\begin{array}{l}\text { Arrangement of } \\
\text { existing } \\
\text { curriculum } \\
\text { materials }\end{array}$ \\
\hline SF & 13 years & 30 & Social sciences & $\begin{array}{l}\text { Implementation } \\
\text { of 'green' } \\
\text { education in a } \\
\text { school for } \\
\text { vocational } \\
\text { education }\end{array}$ & $\begin{array}{l}\text { Learner } \\
\text { materials }\end{array}$ \\
\hline
\end{tabular}

\subsubsection{Instruments}

Semi-structured interview guides for teachers and facilitators were developed based on the theoretical framework and the aim of the study. The interview guides were adapted from Huizinga's (2009) study to address the enacted design process and the support offered. Both interview guides were discussed with an expert in the field of TDTs. In each interview, teachers and facilitators were asked to reflect on the enacted design process. Follow-up questions were posed to gain additional insights into the projects' characteristics (e.g., aim of the project, involved subjects, etc.). Once the key characteristics of the project were clear, the respondents were asked to give a brief overview of problems that occurred and, if applicable, how they overcame the problems related to teachers' curriculum 
design expertise. Finally, the offered support activities and the extent to which they met teachers' needs were discussed.

\subsubsection{Data analysis}

For all interviews, a transcription and a written summary were made. The summaries were based on parts of the transcriptions and were sent to the respondents for member check (Merriam, 1988). These data sources were then analysed using an iterative coding process. In the first step, all summaries were coded using a predefined codebook. For each theme in the interview guides, codes were created based on the extended theoretical framework. The codes referred to the design expertise-related problems TDTs experienced. Table 2.3 shows examples of specific codes that were developed, the description of the code, on which research insights the codes were based and one example quotation to which it was applied.

Inductive coding was applied in order to identify the support activities offered to tackle experienced problems and those activities offered to address teachers' needs (Table 2.4). In addition, inductive coding was applied to retrieve additional insights regarding the problems that occurred during the design process and were not identified ahead of time. 
Table 2.3 Examples of deductive coding of the summaries

\begin{tabular}{|c|c|c|c|c|}
\hline Code & $\begin{array}{l}\text { Related } \\
\text { knowledge and } \\
\text { skills }\end{array}$ & $\begin{array}{l}\text { Description of } \\
\text { code }\end{array}$ & Code based on & Example quote \\
\hline $\begin{array}{l}\text { Received- } \\
\text { support- } \\
\text { consistency }\end{array}$ & $\begin{array}{l}\text { Curriculum } \\
\text { consistency } \\
\text { expertise }\end{array}$ & $\begin{array}{l}\text { Description of a } \\
\text { support activity } \\
\text { that addresses } \\
\text { the internal or } \\
\text { external } \\
\text { consistency of } \\
\text { the lesson series }\end{array}$ & $\begin{array}{l}\text { Kessels (1999), } \\
\text { Van den Akker } \\
\text { (2003) }\end{array}$ & $\begin{array}{l}\text { 'It is about the } \\
\text { assessment, the } \\
\text { alignment, } \\
\text { learning in the } \\
\text { context, the } \\
\text { interdisciplinary } \\
\text { nature and stuff } \\
\text { like that.' }\end{array}$ \\
\hline $\begin{array}{l}\text { Feedback- } \\
\text { teachers }\end{array}$ & $\begin{array}{l}\text { Curriculum } \\
\text { design expertise }\end{array}$ & $\begin{array}{l}\text { Description of } \\
\text { how teachers } \\
\text { gave feedback } \\
\text { on each other's } \\
\text { lesson series }\end{array}$ & $\begin{array}{l}\text { Dick et al. (1985), } \\
\text { Hardré et al. } \\
\text { (2006), } \\
\text { Lunenberg (2002) }\end{array}$ & $\begin{array}{l}\text { 'I always give it } \\
\text { [lesson series] a } \\
\text { Dutch teacher ... } \\
\text { he checks for } \\
\text { spelling mistakes.' }\end{array}$ \\
\hline $\begin{array}{l}\text { Support-most- } \\
\text { valuable }\end{array}$ & All categories & $\begin{array}{l}\text { Description of } \\
\text { the support } \\
\text { activities that } \\
\text { teachers found } \\
\text { the most } \\
\text { valuable }\end{array}$ & $\begin{array}{l}\text { Handelzalts } \\
\text { (2009), Loucks- } \\
\text { Horsley et al. } \\
\text { (1998), Odenthal } \\
\text { (2003) }\end{array}$ & $\begin{array}{l}\text { 'It was a one-day } \\
\text { workshop, in which } \\
\text { we received the } \\
\text { template that we } \\
\text { still use.' }\end{array}$ \\
\hline $\begin{array}{l}\text { Support- } \\
\text { additional- } \\
\text { process }\end{array}$ & $\begin{array}{l}\text { Curriculum } \\
\text { design expertise }\end{array}$ & $\begin{array}{l}\text { Indication of the } \\
\text { need for } \\
\text { additional } \\
\text { support during } \\
\text { the design } \\
\text { process }\end{array}$ & $\begin{array}{l}\text { Handelzalts } \\
\text { (2009), Dick et al. } \\
\text { (1985) }\end{array}$ & $\begin{array}{l}\text { 'Starting and } \\
\text { finalizing tasks. } \\
\text { This could be } \\
\text { improved by } \\
\text { setting strict } \\
\text { deadlines.' }\end{array}$ \\
\hline $\begin{array}{l}\text { Support- } \\
\text { offered-by- } \\
\text { agency }\end{array}$ & All categories & $\begin{array}{l}\text { Description of } \\
\text { the support that } \\
\text { is offered by an } \\
\text { agency }\end{array}$ & $\begin{array}{l}\text { Handelzalts } \\
\text { (2009), Loucks- } \\
\text { Horsley et al. } \\
\text { (1998), Odenthal } \\
\text { (2003) }\end{array}$ & $\begin{array}{l}\text { 'It has to be a } \\
\text { substantial } \\
\text { trajectory, in which } \\
\text { questions are posed } \\
\text { related to } \\
\text { curriculum } \\
\text { development and } \\
\text { the subject matter.' }\end{array}$ \\
\hline
\end{tabular}


Table 2.4 Examples of inductive coding of the transcriptions

\begin{tabular}{|c|c|c|c|}
\hline Code & $\begin{array}{l}\text { Related knowledge } \\
\text { and skills }\end{array}$ & Description of code & Example quote \\
\hline $\begin{array}{l}\text { Concrete examples / } \\
\text { school visits }\end{array}$ & $\begin{array}{l}\text { Curriculum design } \\
\text { expertise } \\
\text { Curricular } \\
\text { consistency expertise }\end{array}$ & $\begin{array}{l}\text { Support offers } \\
\text { concrete examples } \\
\text { (e.g., exemplary } \\
\text { materials) or visits } \\
\text { other schools with the } \\
\text { teacher team }\end{array}$ & $\begin{array}{l}\text { 'We developed exemplary } \\
\text { materials and offered in on } \\
\text { our website.' } \\
\text { 'I offer a lot of examples } \\
\text { and use my experiences } \\
\text { with supporting other } \\
\text { schools.' }\end{array}$ \\
\hline Support activity & All categories & $\begin{array}{l}\text { General description } \\
\text { for support offered. } \\
\text { Made concrete by } \\
\text { using a second code } \\
\text { (e.g., shared vision) }\end{array}$ & $\begin{array}{l}\text { 'Specifically with the } \\
\text { teachers of the } \\
\text { interdisciplinary domain, } \\
\text { we let them think about } \\
\text { how to deal with the } \\
\text { content and how they are } \\
\text { going to offer it.' }\end{array}$ \\
\hline $\begin{array}{l}\text { Experienced } \\
\text { problems }\end{array}$ & All categories & $\begin{array}{l}\text { Description of the } \\
\text { problems experienced } \\
\text { during the design } \\
\text { process. Made } \\
\text { concrete by using a } \\
\text { second code (e.g., } \\
\text { collaborative } \\
\text { enactment) }\end{array}$ & $\begin{array}{l}\text { 'It is difficult to have the } \\
\text { same pace in an } \\
\text { interdisciplinary course as } \\
\text { a colleague of a different } \\
\text { [individual] course.' }\end{array}$ \\
\hline
\end{tabular}

Investigator triangulation was achieved by determining the inter-coder reliability. A research assistant was involved in checking the reliability of the coding done by the first author of this paper. One summary and one transcription were initially coded by the research assistant, and differences in code interpretation were discussed with the first author until consensus was achieved. Then, three out of twelve interviews were re-coded by the research assistant, which led to an acceptable inter-rater reliability (Krippendorff's Alpha) of 0.72.

\subsection{FINDINGS}

Table 2.5 shows which design expertise categories were discussed, which specific knowledge and skills were addressed and how many respondents discussed it (represented with ' $\left.(n=x)^{\prime}\right)$. 
Table 2.5 Categorical overview of design expertise addressed in interviews

\begin{tabular}{|c|c|c|c|c|}
\hline \multicolumn{5}{|c|}{ Specific design expertise } \\
\hline & $\begin{array}{l}\text { Curriculum } \\
\text { design expertise }\end{array}$ & $\begin{array}{l}\text { Subject matter } \\
\text { knowledge }\end{array}$ & $\begin{array}{l}\text { Pedagogical content } \\
\text { knowledge }\end{array}$ & $\begin{array}{l}\text { Curriculum } \\
\text { consistency } \\
\text { expertise }\end{array}$ \\
\hline $\begin{array}{l}\text { Teachers } \\
(\mathrm{N}=6)\end{array}$ & $\begin{array}{l}\text { Problem } \\
\text { statement }(n=3) \\
\text { Systematic } \\
\text { Design }(n=5) \\
\text { Formative and } \\
\text { summative } \\
\text { evaluation }(n=4) \\
\text { Decision-making } \\
(n=4) \\
\text { Implementation } \\
(n=6)\end{array}$ & $\begin{array}{l}\text { Up-to-date } \\
\text { knowledge }(n=4) \\
\text { Insights in } \\
\text { learner } \\
\text { difficulties }(n=4)\end{array}$ & $\begin{array}{l}\text { Pedagogical } \\
\text { repertoire }(n=2) \\
\text { Material selection } \\
(n=5) \\
\text { ICT selection } \\
(n=3)\end{array}$ & $\begin{array}{l}\text { Internal } \\
\text { consistency }(n=4) \\
\text { External } \\
\text { consistency }(n=3)\end{array}$ \\
\hline $\begin{array}{l}\text { Facilitators } \\
(\mathrm{N}=6)\end{array}$ & $\begin{array}{l}\text { Problem } \\
\text { statement }(n=2) \\
\text { Systematic } \\
\text { Design }(n=3) \\
\text { Formative and } \\
\text { summative } \\
\text { evaluation }(n=2)\end{array}$ & $\begin{array}{l}\text { Up-to-date } \\
\text { knowledge }(n=4) \\
\text { Insights in } \\
\text { learner } \\
\text { difficulties }(n=2)\end{array}$ & $\begin{array}{l}\text { Pedagogical } \\
\text { repertoire }(n=4) \\
\text { Material selection } \\
(n=2)\end{array}$ & $\begin{array}{l}\text { Internal } \\
\text { consistency }(n=2) \\
\text { External } \\
\text { consistency }(n=4)\end{array}$ \\
\hline
\end{tabular}

In the subsequent sections, the specific design expertise will be discussed in more detail, starting with curriculum design expertise

\subsubsection{Curriculum design expertise}

All respondents reported on teachers' curricular design expertise in detail (Table 2.6). In general, teachers faced an ill-defined vision about their future classroom practice and therefore had various expectations within the team about the project's outcomes. Furthermore, support was offered to TDTs for the creation of a curricular framework or (lesson-specific) templates. This might imply that teachers require additional knowledge and skills to align single lessons or activities in a well-considered order. Finally, the enactment of evaluations was also supported to enhance the design process. 
Table 2.6 Overview of teachers' curriculum design expertise

\begin{tabular}{|c|c|c|c|c|c|}
\hline & $\begin{array}{l}\text { Problem } \\
\text { statement }\end{array}$ & $\begin{array}{l}\text { Systematic } \\
\text { design }\end{array}$ & $\begin{array}{l}\text { Decision- } \\
\text { making }\end{array}$ & $\begin{array}{l}\text { Formative and } \\
\text { summative } \\
\text { evaluation }\end{array}$ & Implementation \\
\hline $\begin{array}{l}\text { Teachers } \\
(\mathrm{N}=6)\end{array}$ & $\begin{array}{l}\text { - Ill-defined } \\
\text { shared vision } \\
\text { about the } \\
\text { future practice } \\
\text { (TA, TC \& TD) }\end{array}$ & $\begin{array}{l}\text { IA No specific } \\
\text { problems (TA, } \\
\text { TC, TE \& TF) } \\
\text { + Use of } \\
\text { templates (TA, } \\
\text { TB, TE \& TF) } \\
\text { - Organizing } \\
\text { materials in a } \\
\text { well- } \\
\text { considered } \\
\text { order (TA) }\end{array}$ & $\begin{array}{l}\text { IA Practical } \\
\text { usability } \\
\text { discussed } \\
\text { (TA, TB, TE } \\
\& \text { TF) }\end{array}$ & $\begin{array}{l}\text { + Evaluation } \\
\text { enacted with } \\
\text { peers (TA, TD, } \\
\text { TE \& TF) } \\
\text { - Quality } \\
\text { questions of } \\
\text { individual and } \\
\text { combined } \\
\text { materials (TE } \\
\& \text { TF) } \\
\text { SO evaluation } \\
\text { criteria (TE \& } \\
\text { TF) }\end{array}$ & $\begin{array}{l}\text { IA Materials } \\
\text { implemented } \\
\text { (TA, TB, TC, TD, } \\
\text { TE \& TF) } \\
- \\
\text { Implementation } \\
\text { hindered by } \\
\text { context-related } \\
\text { problems (TB \& } \\
\text { TC) }\end{array}$ \\
\hline $\begin{array}{l}\text { Facilitators } \\
(\mathrm{N}=6)\end{array}$ & $\begin{array}{l}\text { - Ill-defined } \\
\text { shared vision } \\
\text { about the } \\
\text { future practice } \\
\text { (SA \& SF) }\end{array}$ & $\begin{array}{l}\text { SO Resources } \\
\text { to design } \\
\text { digital } \\
\text { materials (SE) } \\
\text { SO support } \\
\text { with } \\
\text { construction } \\
\text { of curricular } \\
\text { framework } \\
\text { (SC, SD \& SE) } \\
\text { SO Templates } \\
\text { (SC \& SD) }\end{array}$ & $\begin{array}{l}\text { Not } \\
\text { addressed }\end{array}$ & $\begin{array}{l}\text { - Unfamiliar } \\
\text { with } \\
\text { evaluation } \\
\text { activities (SC } \\
\& S F \text { ) } \\
\text { SO feedback } \\
\text { on materials } \\
\text { (SC \& SF) }\end{array}$ & Not addressed \\
\hline
\end{tabular}

Note: Explanation of symbols (also for subsequent tables): Teachers' experienced problems ' - '; Teachers' knowledge and skills were a catalyst ' + '; Teachers addressed the issue without a judgment 'IA'; Support offered to enhance' teachers' knowledge and skills 'SO'

Four teachers (TA, TB, TE \& TF) reported that the use of templates fostered their design process. They were more aware of stating the lesson series' goals and focusing on the content and not on the specific layout (TA). Two teams (TA's and TB's team) discussed the layout of the lesson and created a template that included the decisions made. Two facilitators (SC \& SF) collaboratively designed templates with TDTs they supported and discussed with the teachers how the intended goals of the reform could be achieved.

Whereas templates were used for the development of individual lessons, teachers in TA's team also articulated the need for a curricular framework. They contacted 
the national institute for curriculum development for such frameworks and used these (externally designed) frameworks to align the individual lessons in a wellconsidered order. Three facilitators (SC, SD \& SE) also argued that teachers require curricular frameworks for the alignment of individual lessons. Surprisingly, none of them reported that they offered such frameworks to TDTs.

Finally, although four teachers indicated that they evaluated the materials developed with their peers (TA, TD, TE \& TF), conducting an evaluation remains difficult. TE and TF, who collaborated in a team, received support to make them more aware of quality criteria and the enactment of evaluations. SC argued that teachers raised questions such as 'Do we cover the attainment targets?' and 'How can we easily develop quality materials?'

\subsubsection{Subject matter knowledge}

None of the respondents reported major problems related to subject matter knowledge (Table 2.7). This implies that teams had sufficient knowledge to design the lesson series, which might indicate that no specific support is needed on this issue.

Table 2.7 Overview of teachers' subject matter knowledge

\begin{tabular}{|c|c|c|}
\hline & Up-to-date subject matter knowledge & $\begin{array}{l}\text { Insights into learners' subject matter } \\
\text { knowledge difficulties }\end{array}$ \\
\hline $\begin{array}{l}\text { Teachers } \\
(\mathrm{N}=6)\end{array}$ & $\begin{array}{l}\text { IA No problems occurred (TA, TC, TD \& } \\
\text { TE) }\end{array}$ & $\begin{array}{l}\text { IA In general sufficient insights (TA \& } \\
\text { TC) } \\
\text { - If subject matter experts leave team, } \\
\text { problems can occur (TE \& TF) }\end{array}$ \\
\hline $\begin{array}{l}\text { Facilitators } \\
(\mathrm{N}=6)\end{array}$ & $\begin{array}{l}\text { IA No problems experienced (SA, SC, } \\
\text { SD, \& SE) }\end{array}$ & IA No problems experienced (SA \& SE) \\
\hline
\end{tabular}

Although no major problems were reported, one team (TE/TF's team) experienced a minor problem when one of the involved subject matter teachers left the TDT. They tackled this problem to involve this teacher in the evaluation activities. One facilitator (SA) supported TDTs by visualizing the subject matter's overlap with a Venn diagram to determine which content was included in the lesson series.

\subsubsection{Pedagogical content knowledge}

Both teachers and facilitators indicated that TDTs had sufficient pedagogical content knowledge to design lesson series. Sometimes support was offered to 
enhance teachers' pedagogical content knowledge related to the interdisciplinary character of the lesson series (see Table 2.8). Furthermore, the results suggest that support is required when TDTs include a new pedagogical approach in existing materials. Thus, it seems that in some specific cases teachers' pedagogical content knowledge is insufficient.

Table 2.8 Overview of teachers' pedagogical content knowledge

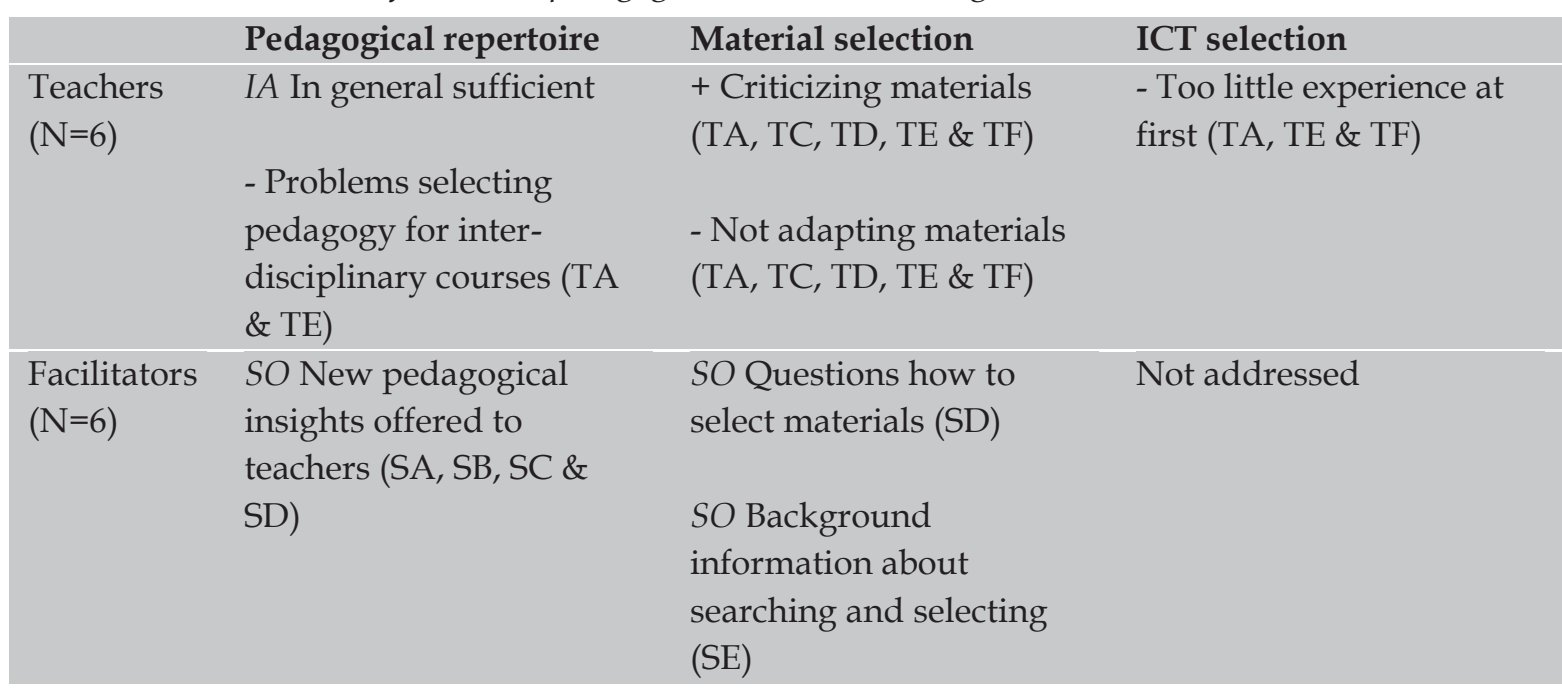

In addition to posing questions (SA \& SC), SB organised workshops in which teachers and learners experienced a new pedagogical approach. Afterwards, SB reflected with teachers and learners on the pros and cons of the new pedagogical approach.

Teachers hardly considered the usage of existing (teacher-made) materials, since they were very critical about the applicability of the material they found online in their own context. Yet none of the teachers indicated that they adapted the materials, which might imply that they lack the required (technical) skills to adapt (digital) materials. TE and TF commented on the usage of existing materials:

TE: 'Assignments were too lengthy or boring or did not address our needs'.

TF: 'The materials did not fit our needs; we could not say we can use these [in our own materials]'.

\subsubsection{Curriculum consistency expertise}

Teachers and facilitators reported problems related to achieving internally and externally consistent lesson series, especially regarding the quality of the lesson series and the team's shared vision (Table 2.9). Therefore, helping TDTs from the 
start to develop a shared vision seems vital to enhance the overall design process. Subsequently, the shared vision can, during a later stage of the design process, be used to evaluate the lesson series and to achieve internal consistency.

Table 2.9 Overview of teachers' curriculum consistency expertise

\begin{tabular}{|c|c|c|}
\hline & Internal consistency & External consistency \\
\hline $\begin{array}{l}\text { Teachers } \\
(\mathrm{N}=6)\end{array}$ & $\begin{array}{l}\text { - Quality of the curriculum materials, } \\
\text { including alignment with attainment } \\
\text { targets (TA, TB, TE \& TF) }\end{array}$ & $\begin{array}{l}\text { + Shared vision fosters design process } \\
\text { (TA, TB \& TD) } \\
\text { - Problems during development of } \\
\text { shared vision (TA, TB \& TD) }\end{array}$ \\
\hline \multirow[t]{2}{*}{$\begin{array}{l}\text { Facilitators } \\
(\mathrm{N}=6)\end{array}$} & $\begin{array}{l}\text { - Quality of the curriculum materials, } \\
\text { including alignment with attainment } \\
\text { targets (SA \& SC) }\end{array}$ & $\begin{array}{l}\text { - Teams lack a shared vision (SA, SC, SD } \\
\text { \& SF) } \\
\text { SO Reflection and discussion foster } \\
\text { development of shared vision (SA, SC, } \\
\text { SD \& SF) }\end{array}$ \\
\hline & & $\begin{array}{l}\text { SO Interpretations of key concepts (SA, } \\
\text { SC \& SF) }\end{array}$ \\
\hline
\end{tabular}

The example of TE/TF's team illustrates the concerns teachers had with the materials they designed themselves. During their design process, they contacted an external facilitator to evaluate the quality of the designed lesson series; the facilitator provided them with feedback on the designed lesson series. Furthermore, he discussed with the TDT how to cover the attainment targets, which made TE and TF more aware of the attainment targets. Finally, he gave the team a checklist to evaluate the lesson series, which they still use. Two facilitators (SA \& SC) reported that they helped TDTs to reflect on how to improve the quality of the lesson series, especially related to alignment with the attainment targets.

In their challenge to reach external consistency, TDTs faced several problems developing a shared vision. These problems occurred since there was no consensus regarding the outcomes of the design process and teams lacked a shared understanding of the main concepts they wanted to include in the lesson series. Consequently, it hindered the teams' design process (TB \& TD). External consistency was achieved by discussing in-depth with the teams how the new materials would be applied in their future practice. The discussions were used to elicit the teams' shared vision that guided the design of, for instance, the activity cards (TB) and learner materials (TD). Also, facilitators stated that TDTs experienced difficulties developing a shared vision. SC discussed with the teacher 
team what each member understood about their main concept and she used this input to visualise the team's discussion. During the discussion, SC posed questions, such as 'What does this mean for the curriculum?' and 'What does this [aspect addressed in discussion] mean for the concept [culture oriented education]?' SA argued that teachers have to 'conceptualise the aim of the reform and why teachers want to achieve this'. He let teachers describe their ideal future practice and tried to align these descriptions.

\subsection{CONCLUSIONS AND DISCUSSION}

This study explored gaps in teachers' design expertise required for designing lesson series. These insights can be used to design and offer support during design processes. Prior research already indicated that teachers require support to tackle design-related problems during design processes (e.g., Ben-Peretz, 1990; Nieveen et al., 2005; Odenthal, 2003; Stenhouse, 1975). However, little was known about the specific kind of support needed to enhance teachers' design expertise. In this study, teachers and facilitators reflected on a school-specific collaborative design process in which they experienced and tackled several problems related to specific design expertise. Based on the results, three gaps in teachers' design expertise were identified, namely:

1. Curriculum design expertise

2. Pedagogical content knowledge

3. Curricular consistency expertise

Each of these gaps will be discussed from the experienced problems and support offered to overcome the problems.

\subsubsection{Curriculum design expertise}

During their design processes, the teachers developed and implemented the lesson series in practice. However, during the process, they experienced several problems. A major problem according to both teachers and facilitators relates to defining the problem statement. Teachers encountered ill-defined shared visions of the future practice at the start of their design process, which affected the design activities (cf. Handelzalts, 2009), especially when teachers within TDTs had different expectations. Subsequently, teachers designed materials which did not suit the newly developed practice. 
Facilitators also recognised TDTs' problems with creating the problem statement. Therefore, they offered support to TDTs to develop the teams' shared vision about the future practice. This support helped teachers to clarify what they wanted to achieve in the design process.

Scholars in the field of instructional and curriculum design strongly articulate the importance of enacting a systematic design processes and enacting evaluation activities (Hardré et al., 2006; Richey et al., 2001; Seels and Glasgow 1991), since it is beneficial for the quality of the designed product (Gustafson, 2002). However, teachers hardly design according to existing design models (e.g., Hoogveld, 2003; Handelzalts, 2009; Kerr, 1981). The results of this study confirm this. We found that teachers hardly performed analysis activities, such as a learner or context analysis. In contrast to Handelzalts (2009, p. 208), who argued that teachers 'are not inclined to initiate evaluation activities of any sort', the teachers in this study enacted several evaluations of the designed lesson series, since they were insecure about the quality of the designed materials. However, facilitators and teachers both reported that teachers did not know how to enact evaluation activities and how to determine the quality of the materials made (cf. Handelzalts, 2009; Kerr, 1981).

The support offered by facilitators to enhance teachers' systematic curriculum design skills mainly focused on the design and evaluation activities, probably because facilitators where not involved in the initial stages of the design process. While supporting the design and evaluation stage facilitators reflected with the team on the shared vision and the expected outcomes. This support also consisted of enacting some activities to clarify the vision. During the design stage support addressed how teachers could design digital materials and offered just-in-time support during the (co-)construction of curricular frameworks and templates. The templates helped teachers to structure the design activities and to focus on the content of the lesson series instead of the materials' layout. Similar support was offered to conduct evaluation activities, since facilitators provided checklists, feedback or taught teachers how to enact evaluations.

In order to increase teachers' curriculum design expertise, it seems essential that TDTs receive support during all stages of the design process (Hoogveld, 2003; Nieveen et al., 2005). Based on the results of this explorative study, it seems essential to support TDTs especially during the analysis stage and evaluation stages since they experience most knowledge and skills-related problems while enacting these activities. 


\subsubsection{Pedagogical content knowledge}

Both teachers and facilitators in this study indicated that TDTs had, in general, sufficient pedagogical content knowledge to design the lesson series. However, some teachers argued that they experienced some minor problems with selecting an appropriate pedagogy to suit the interdisciplinary character of the course. Also, facilitators argued that teachers required new insights in offering interdisciplinary courses (cf. Krajcik, McNeill, \& Reiser, 2007).

Facilitators offered some insights in applying new pedagogy in practice, for example, by offering a workshop to let teachers and students experience a new approach. Given the insights from professional development programs (e.g., Garet et al., 2001; Van Driel, Meirink, Van Veen, \& Zwart, 2012), which indicate the essence of collaborative learning and the connection to teachers' classroom practice, the offered pedagogy-related support seems beneficial for increasing teachers' pedagogical repertoire. In addition, Handelzalts (2009) noted that helping teachers to visualise the future practice by piloting, conducting school visits and discussing blueprints can also be added to enhance teachers' understanding of new pedagogy.

Teachers' ability to select materials suiting the selected pedagogy has been identified as a part of teachers' pedagogical content knowledge for designing (e.g., Huizinga, 2009; Nieveen \& Van der Hoeven, 2011). During the design of lesson series, teachers select and often adapt the materials found to their own context (Remillard, 2005). Teachers in this study criticised the materials found in digital repositories on their practical usability and did not use the materials. Instead, they used the repositories to get inspiration. A reason might be that teachers lack the technical skills to make the required adaptations to the digital materials (cf. Wilhelm \& Wilde, 2005).

Facilitators discussed with teachers how they could search for existing materials and when to select them. One facilitator indicated that his organization also offered background information about the search process for a specific repository. Similar support was provided to experienced teachers as designers in the study of Strijker and Corbalan (2011). Their study illustrated that it improved the search process and that the found materials suited their context.

Finally, the teachers who designed digital materials experienced difficulties related to pedagogy and integration of ICT, especially when they had limited ICT skills in order to design teaching materials. The integration of ICT required that 
teachers are familiar with ICT and able to make adjustments in order to fit it in the teaching materials (cf. Agyei, 2012; Alayyar, 2011).

In order to increase teachers' pedagogical content knowledge for designing, it seems fruitful to gain insights about teachers' pedagogical content knowledge in relation to the expected outcomes (e.g., do they have experience with the new pedagogy). Based on this explorative study, it seems helpful to offer some technical support for teachers to make contextual adaptation to digital materials found on repositories. This prevents that valuable time is lost in creating materials which are already available.

\subsubsection{Curriculum consistency expertise}

Teachers also experienced difficulties in creating curriculum materials that were internally and externally consistent (cf. Handelzalts, 2009; Van den Akker, 2003). The support offered to create internally consistent lesson series was already partly discussed in the previous sections (e.g., templates and helping to conduct evaluations). Teachers felt insecure about the materials' quality, which they partly tackled by using templates. Yang, Fox, Wildemuth, Pomerantz and Oh (2006) also argued that templates are useful to prepare high-quality curriculum materials. For the design of lesson series, they also articulated the need for curricular frameworks to organise the individual materials in a well-considered order. Yet facilitators hardly offered such frameworks, despite their indications that it might be beneficial to offer them to teachers.

External consistency on the other hand was affected by different understandings within TDTs about the key concepts of the reform. Moreover, teachers within TDTs also had different expectations about the lesson series they were designing. A shared vision is required to foster the design and implementation of the lesson series, but it takes some time to develop (Handelzalts, 2009; Hord, 2004).

Handelzalts (2009) provided guidelines for teachers and facilitators to foster the development of the team's shared vision. He suggested that activities should be initialised to help teachers to create concrete images of their future practice. This study showed that such activities included visualizing the team's ideas by using Venn diagrams, posing reflective questions about the team's intentions and expected outcomes and discussing with the team how they wanted to achieve these outcomes. Facilitators used this input to align the vision of the individual teachers. 


\subsubsection{Limitations}

The small-scale nature of this study might limit the scope of the findings of the study. Teachers and facilitators volunteered to participate in the research and might have experienced the design process differently than their colleagues. This limitation was partly tackled by comparing the results with insights from prior research. A second limitation is that both groups of respondents reflected on the design process. The reflection on the process might have been influenced by the feeling of success or failures after implementing it in practice.

\subsubsection{Recommendations}

The results of this study underline the importance of supporting TDTs in the process of creating internally and externally consistent curriculum materials. Furthermore, the study illustrates which support TDTs require related to categories of teachers' design expertise when designing lesson series. This study resulted in three guidelines for supporting TDTs' curriculum and instructional design processes aiming to design lesson series.

First, to enhance the quality of the curriculum design process support should be offered just-in-time as an integrated part of the design process to enhance teachers' design expertise (cf. Garet et al., 2001; Nieveen et al., 2005; Van Driel et al., 2012). Support offered just-in-time fosters the enacted design process. In addition, such support offers professional learning opportunities for teachers to further develop their design expertise. Through just-in-time support, teachers can directly apply the new knowledge and skills gained in the design process.

Second, support should focus on developing teachers' curriculum design expertise, pedagogical content knowledge and curricular consistency expertise. The results of this study illustrate that both teachers and facilitators indicate that teachers experience lack of expertise in these domains, which can be tackled by offering support. Since teachers face knowledge and skills-related problems throughout all stages of the design process the quality of the curriculum design process will be improved if support to enhance teachers' curriculum design expertise, pedagogical content knowledge and curricular consistency expertise is offered from the early stages of the design process.

Third, the results of this study indicate that templates, curricular frameworks and evaluation guidelines are essential tools to support teachers in the design of quality lesson series. TDTs question the quality of the designed lesson series, by offering concrete support such questions can be addressed. 
This study contributed to knowledge about the support teachers need to design quality lesson series to foster enactment of curriculum reform. Follow-up research is required to explore the applicability of the guidelines in other contexts in which curriculum and instructional design is conducted.

Second, follow-up research should explore differences in need for support between different types of design tasks. Designing lesson series is a medium complex design tasks (Nieveen \& Van der Hoeven, 2011), which requires that teachers are able to design and align individual lessons in a well-considered order. For more complex design tasks, such as designing a complete new curriculum, support to foster teachers' design expertise might be different.

Third, although the results of this study suggest that supporting TDTs can enhance teachers' design expertise, additional research is required to determine the effect of support on teachers' ability of designing lesson series.

Finally, follow-up research should examine more closely how support is designed and offered in real-time during collaborative design processes, if and how the current guidelines are applied, and how support affects teachers' design expertise. 


\title{
CHAPTER $3 \dagger$ \\ Fostering teachers' curriculum design expertise in Teacher Design Teams: Conducive design and support activities
}

\begin{abstract}
Supporting Teacher Design Teams (TDTs) during local curriculum development efforts is essential. To be able to provide high quality support, insights are needed about how TDTs carry out design activities and how support is valued by the members of TDTs and how it affects their design expertise. In this study, the design and support processes of two TDTs assisted by an external facilitator were investigated using a case study approach. The results revealed that support offered to TDTs depended on the contextual boundaries and the focus of the design process. The focus, coherence and form of support affected the opportunities for developing teachers' design expertise. In both cases teachers' curriculum design expertise grew, whereas their pedagogical content knowledge and subject matter knowledge hardly developed. Findings show that the most conducive support activities and materials were those that could directly be applied in the design process.
\end{abstract}

\subsection{INTRODUCTION}

Having teachers take on the role of designer in curriculum reform initiatives is considered an important factor for sustainable change (Clandinin \& Connelly, 1992; Hargreaves, 2003). While designing, teachers can align the new curriculum to their wishes, needs and beliefs and to the reform framework, which fosters ownership of the reform (Havnes, 2009).

This chapter is based on the accepted article: Huizinga, T., Handelzalts, A., Nieveen, N., \& Voogt, J. M. (accepted). Fostering teachers' design expertise in Teacher Design Teams: Conducive design and support activities. The Curriculum Journal. 
One way of having teachers take on the role of designer is by involving them in Teacher Design Teams [TDTs] (Deketelaere \& Kelchtermans, 1996; Simmie, 2007). TDTs are teams of teachers who collaboratively analyse, design, develop, implement and evaluate their shared curriculum (Handelzalts, 2009). TDTs can vary in terms of team size, whether the members are from the same or from different schools, and the courses the members offer (Handelzalts, 2009). In this study, we focus on TDTs consisting of teachers from the same school who teach related subjects. Working in such TDTs provides opportunities to share expertise and discuss how the reform affects teachers' classroom practice (Hargreaves, 2003; Havnes, 2009). Moreover, teacher involvement in TDTs can afford learning opportunities (Penuel et al., 2007; Voogt et al., 2011).

Experience shows that working in TDTs is demanding in terms of time and energy (Handelzalts, 2009; Vescio et al., 2008). Moreover, teachers are not adequately educated in curriculum design, which affects if and how teachers conduct design activities (Handelzalts, 2009; Kerr, 1981). For example, teachers as designers hardly conduct analysis activities and tend to directly create curriculum materials. Consequently, they might neglect important aspects that need to be addressed in the materials (e.g., learners' characteristics). To prevent and to overcome such design challenges, teachers as designers require support to tackle knowledge- and skills-related problems (Hardré et al., 2006; Huizinga, Handelzalts, Nieveen, \& Voogt, 2014). Providing support to TDTs through exemplary materials, examples of classroom practices and guidelines for carrying out analysis activities is expected to facilitate the design process (Deketelaere \& Kelchtermans, 1996). To be able to provide high quality support, insights are needed about how TDTs carry out design activities and how support is valued by the members of TDTs and how it affects their design expertise.

This study took place in the context of a Dutch curriculum renewal for teaching foreign languages. Teams of foreign language teachers in schools for secondary education designed and implemented a school-specific curriculum to align with the Common European Framework of Reference of languages [CEFR] (Council of Europe, 2001). A total of 15 TDTs participated in a national project to implement CEFR in their schools. Implementing CEFR required teachers to apply a skillsoriented approach for teaching foreign languages. The participating TDTs received tailored support from curriculum developers (henceforth referred to as facilitators) during a two-year project. This study reports on the first stage of the project and particularly on TDTs that developed curriculum materials aimed at 
the learning of language skills in (simulated) authentic contexts. By integrating the skills-oriented approach and the CEFR-framework in the materials, the curriculum materials would become 'CEFR-proof'.

During the first stage, TDTs carried out analysis, design and development activities. This study focuses on the support offered to TDTs in order to foster teachers' design expertise. The main research question that guided the study was "What design and support activities in TDTs do foster the development of teachers' design expertise?" For answering the main research question the following four subquestions were formulated:

1. What design activities are carried out by TDTs?

2. What support activities are offered to TDTs?

3. How do teachers describe their experience with the conducted design and support activities within their TDTs?

4. How does working in TDTs that are supported by a facilitator affect teachers' design expertise?

\subsection{TEACHERs' DESIGN EXPERTISE}

\subsubsection{Defining teachers' design expertise}

Carrying out curriculum design tasks requires specific expertise, which has been labelled in various ways, including pedagogical design capacity (Brown \& Edelson, 2003), design competencies (Richey et al., 2001) and design expertise (Hardré et al., 2006). This study uses the term design expertise and defines it as "the required knowledge and skills for designing quality curriculum materials". Design expertise itself consists of three aspects: curriculum design expertise, subject matter knowledge and pedagogical content knowledge (Handelzalts, 2009; Huizinga et al., 2014; Kerr, 1981). The TDTs in this study designed a new schoolspecific foreign language curriculum. In order to do so, the teachers in the TDTs had to become familiar with CEFR (subject matter knowledge) and the corresponding strategies for teaching and learning (pedagogical content knowledge), and were expected to design good quality curriculum materials (curriculum design expertise). The remainder of this section elaborates on these three aspects of design expertise. 


\subsubsection{Curriculum design expertise}

Drawing on the phases of curriculum and instructional design models, the relevant knowledge and skills for teachers as designers can be described as (Huizinga, 2009; Richey et al., 2001):

1. Formulating problem statements;

2. Generating ideas;

3. Designing systematically;

4. Underpinning design decisions;

5. Implementing the designed curriculum materials in practice;

6. Planning and conducting formative and summative evaluations.

Carrying out these activities fosters the internal and external consistency of curriculum materials. Whereas internal consistency reflects the logic contingencies of the components of the curriculum (Kessels, 1993; Van den Akker, 2003), external consistency refers to a shared understanding of the content and nature of the curriculum that needs to be designed (Kessels, 1993; Kessels \& Plomp, 1999). Both are important criteria for the quality of curriculum materials.

\subsubsection{Subject matter knowledge}

Teachers are expected to have deep understanding of the goals and content offered in the courses they teach. Subject matter knowledge [SMK] consists of the core concepts and theories in a subject matter domain (Brandes \& Seixas, 1998). These concepts and theories are expected to be included in curriculum materials, as quality curriculum materials are accurate, relevant and up-to-date (Nelson \& Orey, 1991). The design of curriculum materials requires that teachers have accurate and up-to-date SMK.

In the context of this study, teachers as designers need to be familiar with CEFR. For example, they need to be able to distinguish the three language proficiency levels ('basic user', 'independent user' and 'proficient user') and to understand and integrate the formulated can-do statements while designing. These can-do statements prescribe what is expected from learners in terms of vocabulary and grammatical correctness (can) and how learners use the language in practice (do).

\subsubsection{Pedagogical content knowledge}

Shulman (1986, p. 9) introduced the concept of pedagogical content knowledge $[\mathrm{PCK}]$, described as the "dimension of subject matter knowledge for teaching." PCK 
combines SMK and pedagogical knowledge, and is unique for each course (Marks, 1990). Teachers as designers require PCK to select, include and apply various teaching and learning strategies (Marks, 1990; Shulman, 1986) and to determine whether materials and sources fit these strategies (Barrows \& Kelson, 1993). Teachers are expected to select materials (e.g., learner materials or ICT applications) for the specific CEFR proficiency levels that are relevant for their learners.

\subsection{SUPPORT FOR TEACHER DESIGN TEAMS}

Working in TDTs offers opportunities for teacher learning, especially when TDTs receive support "preferably by an external facilitator, to guide teacher learning in TDTs" (Voogt et al., 2011, p. 1243). External facilitators can affect the focus, coherence and form of the TDT activities through their support.

Focus reflects the aim and expected outcomes of the design task. The focus of support needs to be clear and aligned with the design task. Furthermore, the focus needs to be closely related to teachers' practice, which is best determined through discussion between facilitators and the teachers involved (Odenthal, 2003).

Meaningful support is coherent with teachers' goals and expectations (Garet et al., 2001), which can be achieved by conducting a thorough needs analysis. Aligning the content of support with teachers' prior knowledge and (inter)national standards is essential for the relevance and usefulness of support (Garet et al., 2001; Linder, 2011).

Finally, the form of support relates to how support is offered to TDTs. Facilitators and teachers need to discuss their wishes and expectations regarding the form of support (Linder, 2011; Odenthal, 2003). Support offered by a facilitator can be proactive and reactive (Nieveen et al., 2005). During proactive support, structure is provided to TDTs in order to achieve (predetermined) goals. Reactive support is aligned with the TDTs' design processes and is offered based on the articulated needs for support. Patton et al. (2012) argued that a facilitating style which combines proactive and reactive support is expected to result in meaningful support. The support activities and materials offered are expected to be aligned with TDTs and their design processes (Linder, 2011; Van Driel et al., 2012). This just-in-time nature is expected to provide opportunities for teacher learning, since teachers can experiences what it takes to conduct design processes and can (collaboratively) discuss the relevance and usefulness of the support offered. Just- 
in-time support refers to the information offered to teachers when they need it during the design process (Van Merriënboer \& Kirschner, 2013). However, little is known about the specific characteristics of the coherence and form of support offered by an external facilitator (Van Driel et al., 2012).

\subsection{RESEARCH DESIGN}

For answering the main research question a case study approach was applied, since the boundaries between the phenomenon (developing design expertise) and the context (TDTs) cannot be (clearly) drawn. Furthermore, the aim was to identify the activities that teachers experienced to be relevant for developing their design expertise. This required that the design and support activities of the TDTs were identified and could be related to the activities teachers valued. Therefore, a qualitative case study approach was applied (Yin, 2003). The cases are the TDTs faced with the design of CEFR-proof curriculum materials that were to be used in their schools. Within each case, (several) foreign language teachers from one school collaboratively designed new curriculum materials according to CEFR. The unit of analysis is teachers within the TDTs.

\subsubsection{Case selection}

Before the CEFR-project started, the facilitators organised meetings with the TDTs' coordinator and a member of the school's administration. The lead researcher ( $1^{\text {st }}$ author) screened the summaries of these meetings and used these to select cases for this study based on the following selection criteria:

1. Teachers had (basic) prior knowledge about CEFR;

2. Teams already existed and had collaborated on previous projects;

3. Teams expressed their willingness to collaboratively revise their foreign language curriculum;

4. Teams were motivated to integrate CEFR into their foreign language education;

5. The team's design task was to create language tasks.

Language tasks take place in (simulated) authentic contexts and aim at using the language in practice. Based on these criteria, two cases were selected for this study (Table 3.1). 
Table 3.1 Background information for the teams

\begin{tabular}{|c|c|c|}
\hline & Case 1 (Plato) & Case 2 (Thales) \\
\hline $\begin{array}{l}\text { Foreign language } \\
\text { courses offered }\end{array}$ & English, German, French, Spanish & English, German \\
\hline $\begin{array}{l}\text { Number of } \\
\text { members in TDT }\end{array}$ & 5 of 16 foreign language teachers ${ }^{*}$ & All 16 foreign language teachers \\
\hline $\begin{array}{l}\text { Foreign language } \\
\text { teachers with } \\
\text { design experience }\end{array}$ & $\begin{array}{l}9 \text { of } 16 \text { foreign language teachers } \\
5 \text { of } 5 \text { teachers in TDT }\end{array}$ & 8 of 16 foreign language teachers \\
\hline Coordinator & German Teacher & English Teacher \\
\hline $\begin{array}{l}\text { Facilitator } \\
\text { (pseudonym) }\end{array}$ & Jill & Frank \\
\hline
\end{tabular}

Note: 4 teachers started the design process, in the $6^{\text {th }}$ month the fifth teacher enrolled in the team.

The two facilitators were curriculum developers, both former English teachers, familiar with CEFR, and had offered support to TDTs in previous projects.

\subsubsection{Instrumentation}

Data collection occurred during the first year of the two-year CEFR-project when the TDTs developed language tasks. Five instruments and one artefact were used (see Table 3.2). All instruments were discussed in the research team to assess the content validity (Yin, 2003).

At the start of the CEFR-project, a semi-structured interview guide was used to capture the expectations of the TDT's coordinators about the CEFR-project, the articulated need for support and the contextual boundaries. The facilitator administered the interview. The lead researcher made summaries, which were sent to the interviewees for member checking. The member checked versions were used during the study (Merriam, 1988).

An observation schedule was developed and used during design and support meetings. The observation schedule was used to gain insights about the applied design and support activities, the reactions of teachers while designing, the interaction between the TDT and the facilitator and the contextual setting. Summaries were made, which resulted in a chronological overview for each design and support meeting. 


\begin{tabular}{|c|c|c|c|c|}
\hline & \multicolumn{2}{|c|}{ Process reconstruction } & \multicolumn{2}{|c|}{ Support and learning experiences } \\
\hline & RQ1 & RQ2 & RQ3 & RQ4 \\
\hline $\begin{array}{l}\text { Semi- } \\
\text { structured } \\
\text { interview } \\
\text { guide } \\
\text { (coordinator) }\end{array}$ & & $\mathrm{X}$ & & \\
\hline $\begin{array}{l}\text { Observation } \\
\text { schedule }\end{array}$ & $x$ & $x$ & & \\
\hline $\begin{array}{l}\text { Contact } \\
\text { summary } \\
\text { sheet }\end{array}$ & X & & $\mathrm{x}$ & \\
\hline E-mail traffic & $\mathrm{X}$ & $\mathrm{X}$ & & \\
\hline $\begin{array}{l}\text { Reflective } \\
\text { interview } \\
\text { (facilitator) }\end{array}$ & $x$ & $\mathrm{X}$ & & \\
\hline Storyline & $x$ & $x$ & $\mathrm{x}$ & $\mathrm{X}$ \\
\hline
\end{tabular}

Contact summary sheets were used to contribute to understanding teachers' experiences with the support offered. These contact summary sheets consisted of additional field notes made by the researcher during informal talks with teachers and facilitators before and after meetings.

The e-mail 'traffic' between the team's coordinator and the facilitator was analysed to gain additional insights in the design and support activities by the TDT and facilitator. Furthermore, e-mail 'traffic' provided insights in the articulated need for support and teachers' experiences of the conducted design process.

A semi-structured interview was conducted at the end of the first year with each facilitator. This interview addressed the support and the facilitator's experiences with the support process. After the interview a summary was made and sent to the facilitator for member checking.

To capture teachers' reflections on the design and support activities the storyline method was used, which offers teachers the opportunity to reflect on the entire analysis and design process that took about a year (Beijaard et al., 1999). First, the lead researcher explained the storyline method to the teachers. Next, teachers were asked to individually draw a line in a coordinate system, which reflected 
their personal experiences with the conducted design and support meetings. The question that guided this reflection was: "How did you value the design and support meetings that your TDT carried out during the CEFR-project?" In contrast to the original procedure of Beijaard et al. (1999), in which teachers had to recall the activities themselves, teachers received an overview with the topics of the meetings from the lead researcher (e.g., 'support meeting about conducting analysis activities') to support their reflection. Teachers drew their line in a coordinate system ( $x$-axis time in month, y-axis teachers' values of the process, $1=$ very negative, 5 = very positive). After drawing the line, each teacher individually explained the line and clarified the reasons for variations in the line. Next, as was also applied in the study of Handelzalts (2009), the teachers jointly discussed commonalities and differences between their lines. These discussions were used to overcome the subjectivity of the evaluation of the events. The storyline method was extended with a semi-structured group interview addressing the focus, coherence and form of the support. The lead researcher made transcriptions and summaries of the storyline reflection and group interview. The summaries were sent to the teachers for member checking. Teachers were asked to check whether the summaries represented their opinions. The commented summaries were used during data analysis.

\subsubsection{Data analysis}

All data were analysed using 'a priori' coding (Strauss \& Corbin, 1998). In this data analysis technique, a codebook is developed based on a theoretical framework before the coding starts. While analysing, codes are linked to (parts of) the data. To gain additional insights into the support offered to TDTs, inductive coding was applied. During inductive coding, codes emerge from the data. Table 3.3 provides a section of the final codebook, which was used to identify the content of the support and design activities and the corresponding learning experiences.

The first researcher coded the data. Then the codebook and one sample data source were discussed in the team, which resulted in some changes in code descriptions. Differences in coding were discussed until consensus was reached. 
Table 3.3 Section of the final codebook

\begin{tabular}{|c|c|c|}
\hline Main category & Description main category & Example sub code + description \\
\hline $\begin{array}{l}\text { Curriculum Design } \\
\text { Expertise } \\
(\mathrm{CDE})\end{array}$ & $\begin{array}{l}\text { Support offered to foster teachers' } \\
\text { design process and to increase } \\
\text { teachers' ability to apply a relational } \\
\text { and systematic design in order to } \\
\text { design internally and externally } \\
\text { consistent curriculum materials. }\end{array}$ & $\begin{array}{l}\text { CDE-Design Knowledge and skills } \\
\text { about design activities (e.g., } \\
\text { designing blueprints, design } \\
\text { examples, templates, etc.). }\end{array}$ \\
\hline $\begin{array}{l}\text { Pedagogical content } \\
\text { knowledge (PCK) }\end{array}$ & $\begin{array}{l}\text { Support offered to increase teachers' } \\
\text { understanding of using CEFR and } \\
\text { its corresponding language tasks in } \\
\text { practice. }\end{array}$ & $\begin{array}{l}\text { PCK-Repertoire Pedagogical content } \\
\text { knowledge about strategies for } \\
\text { teaching and learning foreign } \\
\text { languages. }\end{array}$ \\
\hline $\begin{array}{l}\text { Subject matter } \\
\text { knowledge (SMK) }\end{array}$ & $\begin{array}{l}\text { Support offered to increase teachers' } \\
\text { understanding of the CEFR } \\
\text { framework and the content of } \\
\text { language teaching in general (e.g., } \\
\text { role of grammar education). }\end{array}$ & $\begin{array}{l}\text { SMK-Update Knowledge about } \\
\text { CEFR (including CEFR levels). }\end{array}$ \\
\hline
\end{tabular}

\subsection{RESULTS}

\subsubsection{Case 1 - Plato's design activities}

Plato's TDT aimed at improving the coherence of the foreign language curriculum by aligning the examination guidelines with CEFR, developing a database with language tasks and improve teachers' understanding of CEFR. Five of the sixteen foreign language teachers formed the TDT. They were granted 1.5 hours per week to work on (re-)designing the foreign language curriculum.

Table 3.4 shows the design activities the TDT carried out, support received and the products developed. Throughout the CEFR-project, the other foreign language teachers were informed about the TDT's progress during staff meetings. 
Table 3.4 Timeline of Plato's TDT

\begin{tabular}{|c|c|c|c|}
\hline Month & TDT's design activities & Support activities & $\begin{array}{l}\text { Designed } \\
\text { products }\end{array}$ \\
\hline 1 & & $\begin{array}{l}\text { Need and context analysis } \\
\text { Official start of CEFR-project } \\
\text { for members of participating } \\
\text { TDTs }\end{array}$ & \\
\hline 2 & & $\begin{array}{l}\text { Meeting } 1 \text { alignment of } \\
\text { examination guidelines and } \\
\text { start of designing language } \\
\text { tasks }\end{array}$ & $\begin{array}{l}\text { CEFR-proof } \\
\text { examination } \\
\text { guidelines }\end{array}$ \\
\hline \multicolumn{4}{|l|}{3} \\
\hline 4 & $\begin{array}{l}\text { Developing language tasks. } \\
\text { E-mail to facilitator about } \\
\text { design experiences and } \\
\text { corresponding issues }\end{array}$ & $\begin{array}{l}\text { Meeting } 2 \text { design of and } \\
\text { feedback on language tasks }\end{array}$ & $\begin{array}{l}\text { Initial language } \\
\text { task }\end{array}$ \\
\hline 5 & $\begin{array}{l}\text { E-mail correspondence about } \\
\text { improved language tasks and } \\
\text { development of assessment } \\
\text { rubric }\end{array}$ & & $\begin{array}{l}\text { Improved } \\
\text { language task } \\
\text { Initial assessment } \\
\text { rubric }\end{array}$ \\
\hline 6 & $\begin{array}{l}\text { E-mail correspondence about } \\
\text { outline team-wide support } \\
\text { meeting }\end{array}$ & & \\
\hline 7 & $\begin{array}{l}\text { E-mail correspondence about } \\
\text { experienced team-wide support } \\
\text { meeting }\end{array}$ & $\begin{array}{l}\text { Meeting } 3 \text { Preparing team-wide } \\
\text { support meeting } \\
\text { Meeting } 4 \text { Team-wide support } \\
\text { meeting }\end{array}$ & $\begin{array}{l}\text { Drafts of five } \\
\text { language tasks }\end{array}$ \\
\hline 8 & $\begin{array}{l}\text { Assessment rubric used in } \\
\text { practice }\end{array}$ & & \\
\hline 9 & Evaluating assessment rubric & $\begin{array}{l}\text { Expert-validation of CEFR- } \\
\text { report about assessment } \\
\text { (organised for all teams) }\end{array}$ & $\begin{array}{l}\text { Improved } \\
\text { assessment rubric }\end{array}$ \\
\hline 10 & Redesigning assessment rubric & & \\
\hline
\end{tabular}

Note: An empty cell implies that no specific design or support activities were reported

The expert-validation was a meeting in which the teachers offered feedback on a report, which was written by the facilitators, on assessing language skills according to CEFR.

\section{Support activities (Plato)}

Plato's TDT received support from Jill, who planned the support by using the outcomes of the initial meeting and her e-mail correspondence with the team's coordinator. Jill provided just-in-time reactive support that was directly aligned with the design activities and articulated need for support.

The support focused on the design and implementation of CEFR using language tasks. Jill mainly addressed teachers' PCK and curriculum design expertise, 
whereas little support was offered to enhance teachers' understanding of CEFR and the proficiency levels (teachers' SMK). Plato's TDT discussed the content offered with Jill and determined if they would use these new insights in their design. All support activities and materials aimed at helping Plato's TDT to tackle problems they experienced and to prepare for classroom implementation.

In Table 3.5, the four support meetings are summarised and provides the form of support. This illustrates the kind of interactions Jill had with Plato's TDT. Jill offered various exemplary materials (language tasks, assessment rubrics) and had discussions with Plato's TDT about the design decisions made.

Table 3.5 Focus and content of support offered to Plato's TDT

\begin{tabular}{|c|c|c|c|c|}
\hline $\begin{array}{l}\text { Support } \\
\text { meeting }\end{array}$ & $\# 1$ & \#2 & $\# 3$ & $\# 4$ \\
\hline $\begin{array}{l}\text { Focus of } \\
\text { support }\end{array}$ & $\begin{array}{l}\text { Design of the } \\
\text { program of } \\
\text { exams and } \\
\text { assessment and } \\
\text { design of } \\
\text { language tasks }\end{array}$ & $\begin{array}{l}\text { Design of } \\
\text { language tasks } \\
\text { and their } \\
\text { corresponding } \\
\text { implementation }\end{array}$ & $\begin{array}{l}\text { Developing } \\
\text { outline for } \\
\text { meeting } 4\end{array}$ & $\begin{array}{l}\text { Classroom } \\
\text { practice and the } \\
\text { design of } \\
\text { language tasks }\end{array}$ \\
\hline \multicolumn{5}{|c|}{$\begin{array}{l}\text { Content of } \\
\text { support (aim } \\
\text { of support) }\end{array}$} \\
\hline$\underline{\text { SMK }}$ & - & $\begin{array}{l}\text { QEA (CEFR } \\
\text { levels) }\end{array}$ & $\begin{array}{l}\text { Team discussion on } \\
\text { how to present } \\
\text { CEFR during } \\
\text { meeting } 4 \\
\text { (Familiarization } \\
\text { with CEFR) }\end{array}$ & $\begin{array}{l}\text { Presentation, } \\
\text { CEFR-game, rating } \\
\text { video clips and } \\
\text { team-discussion } \\
\text { (Familiarization } \\
\text { with CEFR) }\end{array}$ \\
\hline \multirow[t]{3}{*}{$\underline{\text { PCK }}$} & $\begin{array}{l}\text { Feedback } \\
\text { (Analysing } \\
\text { assessment) }\end{array}$ & $\begin{array}{l}\text { Advice, lesson } \\
\text { examples (Using } \\
\text { pedagogy) }\end{array}$ & $\begin{array}{l}\text { CEFR-game } \\
\text { (Discussing } \\
\text { assessment) }\end{array}$ & $\begin{array}{l}\text { Model lesson, group } \\
\text { discussion, video } \\
\text { clips, presentation } \\
\text { about spoken }\end{array}$ \\
\hline & $\begin{array}{l}\text { Reflective } \\
\text { questions } \\
\text { (Analysing }\end{array}$ & $\begin{array}{l}\text { Suggestions, lesson } \\
\text { examples } \\
\text { (Introducing }\end{array}$ & $\begin{array}{l}\text { Examples and } \\
\text { discussion (Using } \\
\text { pedagogy) }\end{array}$ & $\begin{array}{l}\text { interactions (Using } \\
\text { pedagogy) }\end{array}$ \\
\hline & $\begin{array}{l}\text { Brainstorm, } \\
\text { suggestions } \\
\text { (Discussing } \\
\text { pedagogy) }\end{array}$ & $\begin{array}{l}\text { Examples of rubrics, } \\
\text { advice (Discussing } \\
\text { assessment) }\end{array}$ & $\begin{array}{l}\text { Group discussion } \\
\text { (Discussing } \\
\text { language tasks) }\end{array}$ & $\begin{array}{l}\text { Group discussion or } \\
\text { pros and cons } \\
\text { (language tasks) }\end{array}$ \\
\hline
\end{tabular}




\begin{tabular}{|c|c|c|c|c|}
\hline $\begin{array}{l}\text { Support } \\
\text { meeting }\end{array}$ & \#1 & $\# 2$ & \#3 & $\# 4$ \\
\hline \multicolumn{5}{|l|}{$\begin{array}{l}\text { Content of } \\
\text { support (aim } \\
\text { of support) }\end{array}$} \\
\hline $\begin{array}{l}\text { Curriculum } \\
\text { design } \\
\text { expertise }\end{array}$ & $\begin{array}{l}\text { Group discussion, } \\
\text { advice to improve } \\
\text { internal } \\
\text { consistency } \\
\text { (Discussing } \\
\text { examination } \\
\text { guidelines) } \\
\text { Analysis } \\
\text { instrument } \\
\text { (Analysing } \\
\text { existing } \\
\text { examination } \\
\text { guidelines) } \\
\text { Reflective } \\
\text { questions } \\
\text { (Analysing } \\
\text { current practice) } \\
\text { Providing } \\
\text { examples of other } \\
\text { design contexts, } \\
\text { co-designing and } \\
\text { reflecting on } \\
\text { quality } \\
\text { (Designing } \\
\text { examination } \\
\text { guidelines and } \\
\text { language task) }\end{array}$ & $\begin{array}{l}\text { Questioning, } \\
\text { examples of rubrics } \\
\text { (Discussing } \\
\text { assessment and } \\
\text { pedagogy) } \\
\text { Templates, } \\
\text { discussion, } \\
\text { exemplary } \\
\text { materials, } \\
\text { suggestions to } \\
\text { improve internal } \\
\text { consistency, co- } \\
\text { designing and } \\
\text { (written) feedback } \\
\text { on materials } \\
\text { designed } \\
\text { (Designing } \\
\text { language tasks) }\end{array}$ & $\begin{array}{l}\text { Implementation: } \\
\text { Suggestions for } \\
\text { workshop } \\
\text { (Discussing } \\
\text { assessment and } \\
\text { pedagogy) } \\
\text { Presentation, } \\
\text { curriculum } \\
\text { framework, } \\
\text { template, } \\
\text { suggestions for } \\
\text { decision making, } \\
\text { exchanging prior } \\
\text { design experiences } \\
\text { (Designing and } \\
\text { aligning language } \\
\text { tasks) } \\
\text { Suggestions to } \\
\text { create ownership } \\
\text { and shared } \\
\text { understanding } \\
\text { within the team } \\
\text { (Implementing } \\
\text { language tasks) }\end{array}$ & $\begin{array}{l}\text { Implementation: } \\
\text { CEFR-game and } \\
\text { discussions } \\
\text { (Assessment of } \\
\text { spoken } \\
\text { production and } \\
\text { interaction) } \\
\text { Exchanging prior } \\
\text { design experiences, } \\
\text { exemplary language } \\
\text { tasks, just-in-time } \\
\text { support, } \\
\text { suggestions for } \\
\text { formative } \\
\text { evaluations } \\
\text { (Designing } \\
\text { language tasks) }\end{array}$ \\
\hline
\end{tabular}

When reflecting on the support and her facilitating style, Jill found it important to "align [the support] with the prior knowledge. If you want to achieve something, you have to be sure that the gap is not too big." Support aimed at deepening teachers' PCK by offering classroom examples of using CEFR. To foster teachers' curriculum design expertise, she provided exemplary language tasks and discussed with Plato's TDT how they could assess the quality of the language tasks. 


\section{Teacher experiences (Plato)}

The five members of Plato's TDT reflected at the end of the first year on the design and support activities. All storylines start in the month (x-axis) in which the members enrolled in the project; they plotted their experiences ranging from 1 very negative to 5 very positive (Figure 3.1).
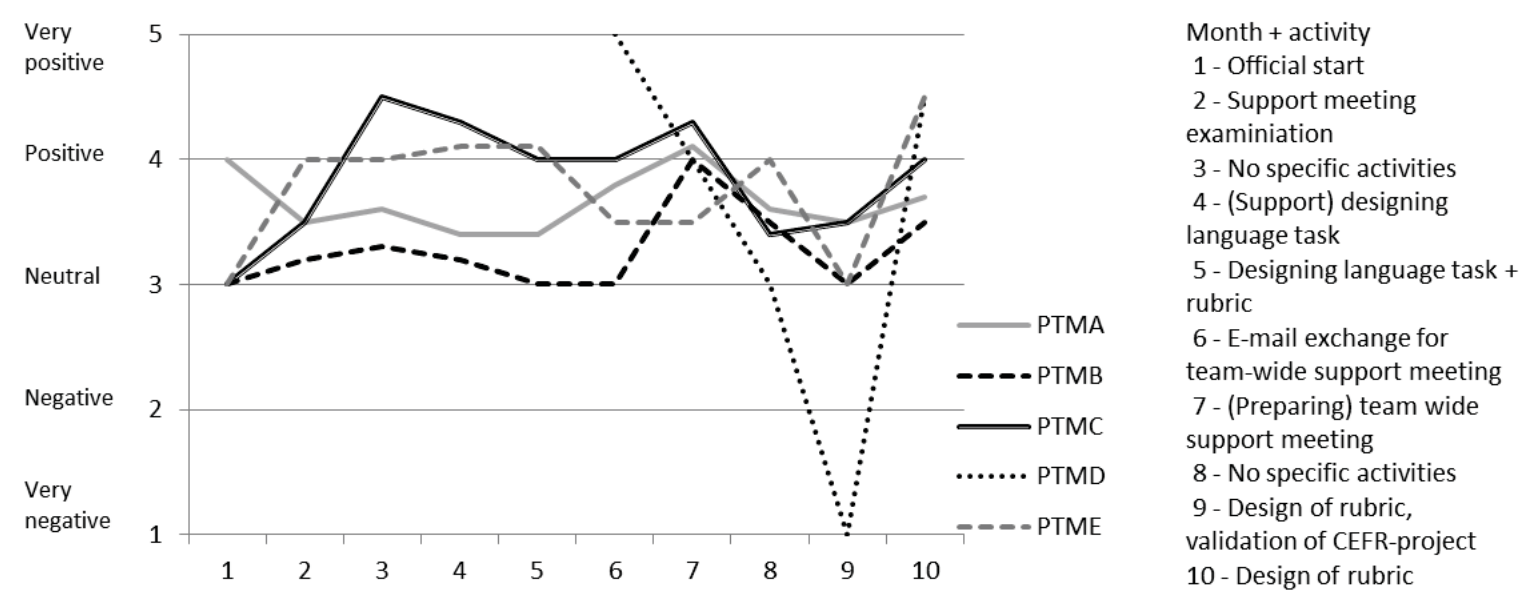

Note: PTMA refers to Plato Team Member A

Figure 3.1 Storylines of the design process as experienced by Plato's TDT

During the first month two meetings were organised (for an overview of all meetings, please refer to Table 3.4). Only PTMA (Plato's coordinator) participated in the needs and context analysis, which she found positive. Both PTMA and PTME went to the official start of the CEFR-project, which PTME found "quite interesting. We had various workshops, and you were informed about the [aims of TDTs in the CEFR-project from] other schools."

Teachers positively valued the redesign of the examination guidelines (second month), as PTMA illustrated: "I don't think we would have accomplished it this soon without the support of Jill." PTMC appreciated Jill's useful suggestion about "a new way for assessing spoken production and interaction."

For PTMA and PTMB, the design of language tasks was a highlight in the $3^{\text {rd }}$ month, but felt less positive in the $4^{\text {th }}$ month. PTMB explained that he questioned if he had the same ideas about language tasks as Jill. PTMA even found that support was lacking: "we had the expectation that we could design and work according to the template [..., but] discovered that there are several systems [templates]." Jill's feedback on their language tasks resulted in a descending line for PTMB, since he questioned if he could use the feedback received. Nevertheless, they redesigned 
the language task and started developing assessment rubric. Plato's TDT also planned and carried out a support meeting for all language teachers of the school, which was one of the highlights of the project (6 $6^{\text {th }}$ and $7^{\text {th }}$ month). PTMB clarified: "I had a very positive feeling, since it [the design process] was shared with the colleagues. [...] we agreed on the next steps to take." PTMD appreciated the discussions about using CEFR in practice. Although PTME found the meeting useful, she was sceptical what their colleagues learned from it.

After the seventh month most lines show a downward trend, with low scores in the ninth month (expert validation meeting). PTMA "expected a cross-school meeting in which we could learn from each other and that's what I've missed [in the process]." PTMD expected practical suggestions and input from the facilitators during the expert validation.

At the end of the first year all lines showed an upward trend. PTMA began "to realise that we have to do it ourselves and [...] we can do it." PTMD added that the upward trend was also the result of the products they designed. Despite the upward trend, PTMB concluded that "too many things are unfinished [at this point]. Until now we had developed too fragmentarily."

\section{Changes in teachers' design expertise (Plato)}

Teachers' curriculum design expertise seems to have been fostered as a result of working in the TDT. PTMA learned that "we have to do this on our own, and [...] we can do it." She felt "capable enough to guide and help her [PTME]. It gives me the feeling that I have mastered it." Exchanging ideas and sharing experiences of their design process with other schools ( $1^{\text {st }}$ month), made PTME aware that "it [implementing CEFR] is a slow process." In addition, she learned from "the things we did in real life, I can still remember those [activities]", in contrast to the support offered by e-mail.

None of the teachers reported learning experiences related to their SMK. Teachers reported mixed learning experiences concerning their PCK. PTMC gained new insights from redesigning the examination guidelines and the support Jill offered about assessing CEFR: "Then we discussed spoken production and interaction [...]. A new way of looking at it and very important". PTME experienced the added value of the support: "She made us think about examination guidelines and how we could best divide it. [...] Yet none of us, including Jill, [knows how to do it]. It still feels as if we are thrown to the wolves." PTMD learned from the meeting with all teachers, since "we could discuss it [using CEFR] with all our colleagues." PTMB believed that most 
learning gains were the result of "successfully using a language task, [...], you use it, evaluate it and improve it [...] It is a step in the right direction." PTMA also acknowledged the added value of support; however, despite the support "we are still uncertain during the design and implementation [of the language task]."

\subsubsection{Case 2 - Thales' design activities}

Thales' TDT included all 16 foreign language teachers. The aim of Thales' CEFRproject was to develop and integrate language tasks within the foreign language curriculum. Since Thales enrolled in the project late, teachers were only facilitated to attend the support meetings. Two design processes were initiated namely, 1. the design of a vision document (4 of 16 teachers - the lead TDT), 2. the design of language tasks (all 16 teachers).

Table 3.6 Timeline of Thales' TDT

\begin{tabular}{|c|c|c|c|}
\hline Month & $\begin{array}{l}\text { TDT's design activities } \\
\text { (lead TDT) }\end{array}$ & Support activities & $\begin{array}{l}\text { Designed } \\
\text { products }\end{array}$ \\
\hline 1 & & $\begin{array}{l}\text { Meeting } 1 \text { Introducing CEFR levels } \\
\text { and pedagogy } \\
\text { Official start of CEFR-project for } \\
\text { members of participating TDTs } \\
\text { Initial needs and context analysis } \\
\text { with facilitator }\end{array}$ & \\
\hline \multicolumn{4}{|l|}{2} \\
\hline 3 & $\begin{array}{l}\text { Preparation for vision document } \\
\text { development (by coordinator) }\end{array}$ & & \\
\hline \multicolumn{4}{|l|}{4} \\
\hline \multicolumn{4}{|l|}{5} \\
\hline \multicolumn{4}{|l|}{6} \\
\hline 7 & $\begin{array}{l}\text { Start of the design of vision } \\
\text { document }\end{array}$ & $\begin{array}{l}\text { Meeting } 2 \text { Discussing outline } \\
\text { of CEFR-project (Frank and coordina }\end{array}$ & \\
\hline 8 & $\begin{array}{l}\text { Design of vision document } \\
\text { (learning goals) } \\
\text { Discussion regarding role of } \\
\text { grammar education } \\
\text { Writing vision document based on } \\
\text { template }\end{array}$ & & $\begin{array}{l}\text { First } \\
\text { version of } \\
\text { vision } \\
\text { document }\end{array}$ \\
\hline 9 & Development of vision document & $\begin{array}{l}\text { Meeting } 3 \text { Conducting analysis } \\
\text { activities } \\
\text { External meeting: Expert-validation } \\
\text { of CEFR-report about assessment } \\
\text { (organised by all facilitators of } \\
\text { CEFR-project) } \\
\text { Meeting } 4 \text { Designing language tasks }\end{array}$ & $\begin{array}{l}\text { Five draft } \\
\text { language } \\
\text { tasks }\end{array}$ \\
\hline
\end{tabular}

Note: An empty cell implies that no specific design or support activities were reported 
Given the late enrolment of Thales in the CEFR-project, few activities were conducted in the first six months (see Table 3.6). After this period, when the new school year started, the foreign language teachers were facilitated to participate in the support meetings. Furthermore, the lead TDT was formed and started with the development of the vision document. During the support meetings (see Table 3.6), all foreign language teachers were designing the language tasks, also the members of the lead TDT. In this case description the emphasis is on the activities as conducted by the lead TDT and their experiences of these activities.

\section{Support activities (Thales)}

Four support meetings were offered by Frank (facilitator). Frank planned and discussed the outline of the support with the team's coordinator ( $2^{\text {nd }}$ meeting). The first meeting addressed the pros and cons of CEFR, during the second meeting the outline of the design process was determined and the third and fourth addressed analysing existing materials and designing language tasks. Frank's support style was proactive. Support was planned before the meeting commenced, although during the hands-on tasks Frank offered just-in-time support. Observations of design and support meetings revealed that teachers only designed language tasks during the support meetings. Thales' lead TDT used their design meetings for the development of the vision document.

The focus of support was on the systematic design of language tasks. Two meetings directly related to a specific phase of the ADDIE-model (analysis and design). During all meetings standards for creating high quality curricula were included, often in the presentation. The support Frank offered consisted of a presentation with discussions, followed by hands-on tasks. In Table 3.7 the focus of and content for the support meetings is provided. The form illustrates the interaction between Frank and the teachers. The emphasis was on teachers' curriculum design expertise both in terms of focus and content. Only the first support meeting emphasised teachers' SMK and PCK. Support activities and materials were used for specific design activities and aligned with a specific phase of the design process. Frank offered presentations with background information, exemplary materials (language tasks), (discussed the) template, and gave advice while teachers were designing.

Frank deliberately chose this approach, because "based on the input [a facilitator provides], quality products can be developed [by the TDT]." Teachers indicated that "a lot of input was provided. [... and only support meeting four] could be characterised as a 
design meeting." In his reflection on the support offered, Frank reported that balancing theory and practical experiences remains difficult, because he believed that the teachers wanted to start designing right away and were not interested in knowledge about how to conduct curriculum design.

Table 3.7 Focus and content of support offered to Thales' TDT

\begin{tabular}{|c|c|c|c|c|}
\hline $\begin{array}{l}\text { Support } \\
\text { meeting }\end{array}$ & \#1 & $\# 2$ & $\# 3$ & $\# 4$ \\
\hline $\begin{array}{l}\text { Focus of } \\
\text { support }\end{array}$ & $\begin{array}{l}\text { CEFR and } \\
\text { language } \\
\text { education }\end{array}$ & $\begin{array}{l}\text { Outline of } \\
\text { support }\end{array}$ & $\begin{array}{l}\text { Conducting } \\
\text { analysis activities }\end{array}$ & $\begin{array}{l}\text { Designing } \\
\text { language tasks }\end{array}$ \\
\hline \multicolumn{5}{|l|}{$\begin{array}{l}\text { Content of } \\
\text { support (aim } \\
\text { of support) }\end{array}$} \\
\hline$\underline{\text { SMK }}$ & $\begin{array}{l}\text { Presentation } \\
\text { (CEFR) }\end{array}$ & & $\begin{array}{l}\text { Background } \\
\text { document (Goals } \\
\text { of the languages) }\end{array}$ & $\begin{array}{l}\text { Advice } \\
\text { (Connection with } \\
\text { CEFR levels) }\end{array}$ \\
\hline PCK & $\begin{array}{l}\text { Presentation, } \\
\text { discussion (CEFR } \\
\text { and grammar } \\
\text { education) }\end{array}$ & & $\begin{array}{l}\text { Advice (Finding } \\
\text { and replacing } \\
\text { existing materials) }\end{array}$ & $\begin{array}{l}\text { Design example } \\
\text { (Relation between } \\
\text { language tasks } \\
\text { and CEFR levels) } \\
\text { Advice (Improving } \\
\text { learners' reading } \\
\text { skills) }\end{array}$ \\
\hline $\begin{array}{l}\frac{\text { Curriculum }}{\text { design }} \\
\text { expertise }\end{array}$ & & $\begin{array}{l}\text { Advice to develop } \\
\text { vision document } \\
\text { and applying } \\
\text { approach for } \\
\text { designing language } \\
\text { tasks, discussion } \\
\text { (Systematic } \\
\text { design) } \\
\text { Analysis question } \\
\text { (Analysing } \\
\text { current practice) } \\
\text { Template, design } \\
\text { example (Design of } \\
\text { language tasks) }\end{array}$ & $\begin{array}{l}\text { Presentation, } \\
\text { analysis task for } \\
\text { teachers, feedback } \\
\text { on tasks } \\
\text { (Conducting } \\
\text { analysis activities) } \\
\text { Suggestions during } \\
\text { the presentation } \\
\text { and while teachers } \\
\text { present analysis } \\
\text { outcomes } \\
\text { (Decision- } \\
\text { making) } \\
\text { Template, design } \\
\text { examples, } \\
\text { presentation and } \\
\text { exemplary materials } \\
\text { (Design of } \\
\text { language tasks) }\end{array}$ & $\begin{array}{l}\text { Feedback on tasks } \\
\text { (Conducting } \\
\text { analysis activities) } \\
\text { Design task, design } \\
\text { examples, template, } \\
\text { feedback on tasks, } \\
\text { exemplary } \\
\text { materials, } \\
\text { presentation } \\
\text { (Design of } \\
\text { language tasks) } \\
\text { Posing evaluation } \\
\text { questions, referring } \\
\text { to evaluation } \\
\text { instrument } \\
\text { (Formative } \\
\text { evaluations) }\end{array}$ \\
\hline
\end{tabular}




\section{Teacher experiences (Thales)}

The four teachers in Thales' lead TDT reflected on the design and support activities. Each member drew a line, beginning at the month (x-axis) they enrolled in the project. Their storylines are provided in Figure 3.2; 1 on the y-axis means very negative and 5 is very positive.
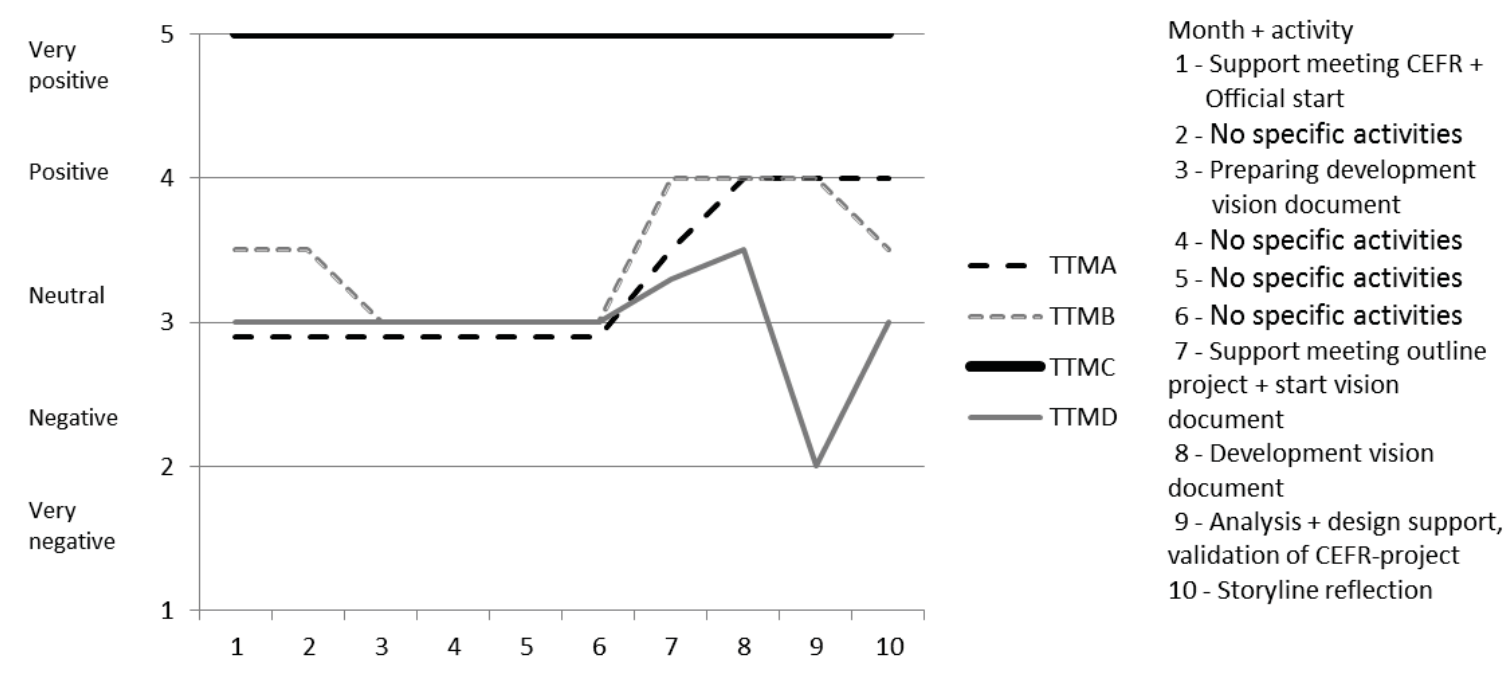

Note: TTMA refers to Thales Team Member A

Figure 3.2 Storylines of the design process as experienced by Thales' lead TDT

Three meetings were organised in the first month (see Table 3.6). After the first support meeting, Thales' teachers decided to enrol in the CEFR-project. Reflecting on the start of the project, TTMB reported: "I didn't know what we were going to do and eventually it all became clear to me." TTMA experienced the same: "Neutral, since it is still disconnected from practice." Finally, TTMC (coordinator) reflected "I appreciated that [...] we can develop a plan and collaboratively develop our future [foreign language curriculum]."

Between the second and sixth month no specific design activities were reported, except the coordinator's search for an outline for the vision document. TTMC valued Thales' participation and willingness to revise the curriculum. She explained: "Every time I saw things happening [...], things I could not clarify to you [other teachers], but Frank could." Reflecting on the whole process, TTMC was very positive about her participation in the project, resulting in a line that did not change over time.

Developing the vision document resulted in an upward trend for three teachers $\left(7^{\text {th }}\right.$ month). TTMA experienced the added value: "I realised 'this is something useful' and 
that is very important for me." TTMB reported: "[...] the moment we started with the vision meetings, because, [...] it became clear what we were going to do." TTMA added: "[...], especially since we could discuss it with each other. It gave me a clear picture." According to TTMA, TTMC and TTMD the most fruitful meeting took place in the seventh month, as TTMD commented: "we decided that we did not throw everything away [...]. We keep the good things and the other things will be supplemented or improved."

Two support meetings were offered in the ninth month, which resulted in a descending line for TTMB and TTMD. During the group discussion, TTMA argued that he "lost the overview of the project," whereas TTMD believed that "Frank's support meetings were partly intertwined [with the lead TDT's design process]." Moreover, TTMD explained he did not understand anything from the meeting regarding the analysis activities. The final support meeting was more practical, which resulted in an upward trend in the line for TTMD. In contrast, TTMB found this meeting less useful, because she had to design language tasks for her colleagues instead of tasks for her own classroom practice.

\section{Changes in teachers' design expertise (Thales)}

Teachers in the lead TDT reported that they gained insights regarding curriculum design expertise. TTMD recalled: "I think that we need the theory, to know where we are [in the design process] and what we are doing." TTMA learned from the design of the vision document that curriculum design also implies that not everything needs to be redesigned. According to TTMA and TTMB, the examples Frank gave of design processes in other schools helped them to understand which steps to take and what to design. Based on her experiences, TTMA realised that in the next stages of the design process: "we have a given amount of time and have to identify what is feasible [to complete]."

None of the teachers reported learning experiences related to their SMK. Only TTMB reflected on her SMK, since she still "finds it difficult to illustrate to the learners [...] what can-do statements are."

Finally, teachers reported few learning experiences related to their PCK. TTMA learned that teaching according to CEFR does not imply that everything that they were doing was wrong: "[I] really think differently about CEFR." TTMB indicated: "We talked with each other about it [strategies for teaching]. I think that we already knew it, but now it became clear." Finally, TTMB illustrated: "It is great that Frank introduced it [CEFR] differently, since everyone [colleagues] might think that you [TTMC] throw everything [current curriculum] away." 


\subsection{CONCLUSION AND DISCUSSION}

The current study was set out to identify design and support activities that are beneficial for developing teachers' design expertise while teachers are involved as designers during design processes. The results of this study provide evidence how design activities and external support can positively contribute to teachers' design expertise. As Borko (2004) argued, small-scale studies are essential to create proof that specific approaches are beneficial for teacher learning.

\subsubsection{TDTs' design and support activities}

The design and support activities of both TDTs showed similarities (see Table 3.4 and 3.6). Both TDTs developed language tasks (using the same template) and additional materials (e.g., assessment rubrics, vision document). As a result of the initial needs and context analysis the facilitators of both TDTs attuned their support to teachers' prior knowledge and the contextual boundaries of the case. In both cases the support activities required active participation of the teachers (e.g., by experiencing the new pedagogical approach or by conducting a specific design activity).

Findings also showed differences between the TDTs. Since the focus and form of support differed between the TDTs (see Table 3.8), the specific design and support activities that were undertaken by the TDT and facilitator also differed (e.g., the moment in the design process in which the design template was introduced and used by the TDT). Furthermore, the TDTs differed in the structure of the overall design process. Plato's TDT started with the alignment of examination guidelines and continued with designing language tasks and assessment rubrics. New design activities were initiated when Plato's TDT completed a previous one. The support offered to Plato's TDT was aligned with the progress of the TDT and thus with the specific design activities that were conducted. In contrast, in Thales two design processes took place simultaneously: the development of the vision document and the design of language tasks. Thales' teachers only received support during the design of the language tasks. This support helped the teachers to systematically approach the design of the language tasks. A comparison between the support offered to Plato and Thales is provided in Table 3.8. Whereas Plato's TDT received reactive just-in-time support, Thales' teachers received mainly proactive (pre-structured) support. 
Table 3.8 Comparison between Plato and Thales

\begin{tabular}{lll} 
Case & Plato & Thales \\
\hline $\begin{array}{l}\text { Focus of } \\
\text { support }\end{array}$ & Design and implementation of CEFR & Systematic design of language tasks \\
\hline Coherence & $\begin{array}{l}\text { Aligned with teachers' goals and } \\
\text { international standards }\end{array}$ & $\begin{array}{l}\text { Aligned with teachers' goals and } \\
\text { international standards }\end{array}$ \\
\hline Support form & $\begin{array}{l}\text { Just-in-time support } \\
\text { Reactive support }\end{array}$ & $\begin{array}{l}\text { Workshops with hands-on tasks } \\
\text { Proactive support }\end{array}$ \\
\hline $\begin{array}{l}\text { Support } \\
\text { activities }\end{array}$ & $\begin{array}{l}\text { Brainstorming } \\
\text { Discussions between TDT and Jill } \\
\text { Feedback on designed materials } \\
\text { Experiencing and illustrating } \\
\text { pedagogy }\end{array}$ & $\begin{array}{l}\text { Presentation about specific topic } \\
\text { Experiencing and illustrating design } \\
\text { activities }\end{array}$ \\
& Fostering ownership & \\
\hline $\begin{array}{l}\text { Support } \\
\text { materials }\end{array}$ & $\begin{array}{l}\text { Template for language tasks } \\
\text { Exemplary language tasks }\end{array}$ & $\begin{array}{l}\text { Template for language tasks } \\
\text { Template for vision document } \\
\text { Exemplary assessment rubrics }\end{array}$ \\
& $\begin{array}{l}\text { CEFR-game } \\
\text { Lesson examples (e.g., videos) }\end{array}$ & \\
\hline
\end{tabular}

The activities that were directly aligned with the design process and resulted in concrete products (e.g., language tasks) or in which important design decisions were made (e.g., about using the foreign language in the classroom) were highly valued by teachers (Garet et al., 2001; Handelzalts, 2009). Activities that were illaligned with the progress of the design process or did not fit teachers' expectations (e.g., providing feedback on CEFR-report about assessment report instead of receiving support how to assess language skills according to CEFR) were not valued by teachers. Teachers' reflections on the activities suggest that the highly valued activities seem to provide meaningful opportunities for teacher learning.

\subsubsection{Developing curriculum design expertise}

The results of this study revealed that three specific activities seem to offer opportunities for developing teachers' curriculum design expertise: (1) the use of exemplary materials, (2) evaluating the designed materials, and (3) sharing experiences with the conducted design process.

First, the exemplary materials and the design template were highly appreciated by the teachers. Using exemplary materials (e.g., language tasks, assessment rubrics) seem to have improved teachers' understanding of how to translate the CEFRframework to curriculum materials. The materials helped to improve the design 
process, since the materials gave them inspiration for and insight in possible outcomes of the design process. Furthermore, the materials helped teachers to better understand the renewal, which offered opportunities to develop teachers' PCK (Ball \& Cohen, 1996; Davis \& Krajcik, 2005; Van den Akker \& Voogt, 1994).

Second, by evaluating the materials (e.g., by providing collegial feedback) that the team had designed teachers got the feeling that they mastered the design process. Furthermore, the evaluations offered opportunities for discussion within the team on how to improve the materials. In Plato, teachers received feedback from their external facilitator on the materials. Such feedback can be beneficial for developing teachers' knowledge and skills, when the feedback is aligned with teachers' expectations of the feedback (Huizinga et al., 2014), which was, however, not the case in Plato. This conclusion is confirmed by other studies that showed that conducting evaluation activities and reflecting on the results assists designers to understand how to further improve the quality of the materials (Nieveen, 2009; Richey et al., 2001; Seels \& Glasgow, 1991).

Third, throughout the design process Plato's TDT shared its experiences of the design process with their colleagues outside the team. One particular meeting in which all foreign language teachers were involved was highly valued by Plato's TDT. Discussing the progress of the design process with fellow colleagues required Plato's TDT to explain what they had done and what they had achieved. In addition to sharing experiences within their school, both TDTs discussed their intended outcomes of the design process at the start of the CEFR-project with teachers of other schools. By sharing the intended outcomes and the progress of the design process, teachers were required to make their process and their achievements explicit. As Hall and Hord (2010) stated, it helps teachers to identify what is achieved in the process, because it makes the teachers more aware of the complexity of the design process and the design challenges they have tackled. Based on the results of this study, it can be concluded that sharing experiences offers opportunities for developing teachers' curriculum design expertise and PCK.

Although reflections of teachers on the designed materials offers opportunities to develop teachers' expertise, sharing the insights and clarifying the results to colleagues outside the TDT seems to offer one of the strongest opportunities for developing expertise (Anto, 2013; Hall \& Hord, 2010). The results of this study indicated that teachers in Plato's TDT had the opportunity to share their insights with colleagues outside the TDT. In general, sharing experiences was limited to 
sharing with colleagues from the same school. It also seems promising to share the experiences with teachers from other schools. At the start of the design process, the TDTs did communicate their expectations of the design process and also gained new insights about possible challenges they could face. Therefore it seems promising to include opportunities for TDTs to exchange their insights with teachers outside their school as it can help other TDTs to tackle design challenges and provide new ideas to plan and conduct the design process.

\subsubsection{PCK and SMK}

This study illustrated that teachers' curriculum design expertise was fostered by teachers' and facilitators' involvement in TDTs, whereas the development of PCK and SMK was limited. The limited development of teachers' PCK and SMK could be explained by the structure of the study and criteria used when selecting the teams. As only teams were selected who had a basic understanding of CEFR, it might be that this affected the learning opportunities regarding PCK and SMK. In addition, since support was aligned to teachers' prior knowledge, less support was offered addressing PCK and SMK.

An additional reason regarding the mixed results of the development of teachers' PCK might be explained by the lack of curriculum enactment in this phase of the work of the TDTs. As Clarke and Hollingsworth (2002) discussed developing teachers' PCK requires that teachers enact the (new) curriculum in practice. In the timeframe of this study the classroom enactment was not included, since curriculum design activities were emphasised in this stage. Curriculum enactment and reflection of the enactment process are known for its opportunities for teacher learning (Voogt et al., 2011), therefore follow-up research should also examine the implementation and evaluation activities of the TDTs and how this possibly levers teachers' PCK. During these activities teachers use the new curriculum materials in their classroom practices and may experience potential gaps in their knowledge and skills.

\subsubsection{Storyline approach}

In this study an important method to answer the research questions was the storyline approach. Teachers were required to explicate their experiences by drawing their storyline and clarify the line they drew. Previous studies (e.g., Beijaard et al., 1999; Handelzalts, 2009) reported that teachers find it difficult to 
draw the storyline and to clarify the line, especially when teachers are required to reflect on a longer period of time and receive little support to reflect. To overcome this challenge, the researcher provided the teachers with an overview of activities (e.g., support meeting about analysis) in order to help them to identify the activities that they have conducted during the first year of the project. Based on this study, it can be concluded that the overview did help teachers to recall what happened during the activities and based on that they were able to reflect on and describe how they experienced the activities.

Beijaard et al. (1999) also argued that the subjectivity of the evaluation of important experiences and events can be a downside of the storyline approach. To overcome this challenge, we followed the procedure that was used by Handelzalts (2009). Teachers were offered the opportunity to discuss their story lines with each other. After drawing the line, each teacher clarified the line to the colleagues and the researcher. The other colleagues were asked not to respond on the line itself. Once all teachers clarified their lines, commonalities and differences between the lines were identified and additional clarifying questions were posed by researcher. The additional clarifications offered further insights in how teachers valued the activities and in doing so this additional activity helped in partly resolving the subjectivity issue.

In conclusion, based on the results of this study it becomes clear that it is possible to develop teachers' curriculum design expertise in the context of TDTs. However, it requires that the focus of support is aligned with the aim of the design process of the TDT. Moreover, facilitators need to offer support that is coherent with teachers' goals by taking international standards and teachers' prior expertise in curriculum design into account while preparing support meetings. Support needs to be attuned with teachers' expectations of the role of the facilitator and the contextual boundaries in which the support is offered. Balancing proactive and reactive support seems a good way to overcome the limitations of the individual facilitating styles and is expected to result in meaningful and relevant support for TDTs. During the design and support process, the following guidelines need to be taken into account during the analysis, design and development stage by the TDTs and their facilitators: (1) the support activities and exemplary materials or templates are directly applicable in the design of curriculum materials, (2) teachers conduct evaluation activities (e.g., providing collegial feedback and screening the materials) and use the outcomes to 
improve the curriculum materials and (3) teachers share their experiences with teachers inside and outside their TDT. These insights can be used to further align support for TDTs during design processes. 


\section{CHAPTER $4^{\ddagger}$ \\ Implementation and evaluation activities in design teams: Opportunities for enhancing teachers' curriculum design expertise}

Teacher involvement in curriculum design is expected to foster the implementation process, especially when teams of teachers collaborate in Teacher Design Teams (TDTs). However, little is known about the implementation and evaluation activities TDTs carry out as part of the overall design process and its relation with teachers' curriculum design expertise. The implementation and evaluation activities of three TDTs were investigated using a case study approach. Teachers' design expertise seemed sufficient concerning implementation, but use of the materials in the classroom practices varied within and between TDTs. The classroom use of the materials did not always represent the renewal completely. Teachers' curriculum design expertise on evaluation was limited; in particular they lack skills to evaluate how materials were used in the classroom and the effects on students. To enhance teachers' curriculum design expertise support needs to address the planning of the implementation process and to focus on how to conduct systematic evaluation.

\subsection{INTRODUCTION}

Involving teachers as designers of curricula fosters teacher learning and the successful implementation of new curricula (Darling-Hammond \& McLaughlin, 1995; Fullan, 2007). Fulfilling the designers' role requires specific knowledge and skills identified as

‡ This chapter is based on the submitted article: Huizinga, T., Handelzalts, A., Nieveen, N., \& Voogt, J. M. (submitted). Implementation and evaluation activities in design teams: Opportunities for enhancing teachers' design expertise. 
(teachers') design expertise (Hardré et al., 2006; Huizinga et al., 2014) (In this study we use the term expertise to address knowledge and skills). Design expertise consists of contributing knowledge and skills (e.g., subject matter knowledge and inter-personal skills) and curriculum design expertise (Huizinga, 2009).

Conducting design activities can foster teachers' curriculum design expertise, especially when teachers collaboratively design and reflect on their experiences (Handelzalts, 2009; Havnes, 2009). Collaboration, in so-called Teacher Design Teams [TDTs; teams of teachers of who collaboratively (re)design part of their (shared) curriculum] (Handelzalts, 2009), implies that teachers work together throughout the analysis, design, development, implementation and evaluation phases of a new curriculum (also referred to as the ADDIE model, Gustafson \& Branch, 2002).

Classroom implementation and evaluation seem to offer strong opportunities for teacher learning, especially when teachers reflect on their experiences (Guskey, 2000; Voogt et al., 2011). Despite the importance of implementing and evaluating a new curriculum, little is known how teachers carry out these activities and which expertise they require (e.g., Handelzalts, 2009; Kerr, 1981).

In the current study, TDTs of foreign language teachers from secondary schools in the Netherlands were faced with the implementation of the Common European Framework of Reference for Languages [CEFR]. Implementing CEFR requires teachers to apply a skill-oriented approach for learning languages, which also implies that the role of grammar education changes. Furthermore, teachers are expected to guide their students in the learning process instead of offering instruction. During a two-year project 15 TDTs designed and implemented a new curriculum, which was aligned to CEFR. The first stage of the CEFR-project was used by TDTs to design authentic tasks (language tasks for students), assessment rubrics and examination guidelines. These materials were implemented and evaluated during the second stage of the CEFR-project.

This study reports on the implementation and evaluation activities conducted by TDTs during the second stage. These activities are assumed to provide opportunities to enhance teachers' curriculum design expertise. The question that guided this study was: 'What implementation and evaluation activities during the design of a new curriculum do provide opportunities for enhancing teachers' curriculum design expertise?' For answering the main research question the following subquestions were formulated: 
1. What implementation and evaluation activities did TDTs conduct?

2. How do teachers experience the implementation and evaluation activities that were conducted in the TDT?

3. What implementation and evaluation activities did teachers conduct in their own classroom practice?

4. How do teachers experience the implementation and evaluation activities that were conducted in their own classroom practice?

\subsection{CURRICULUM DESIGN EXPERTISE}

For the design of internally and externally consistent curricula, teachers require specific expertise to carry out curriculum design processes (Huizinga, 2009; Kessels \& Plomp, 1999; Richey et al., 2001). For curriculum design six types of expertise were identified (Huizinga, 2009):

1. Formulating problem statements;

2. Generating ideas;

3. Designing systematically;

4. Underpinning design decisions;

5. Implementing the designed curriculum materials in practice;

6. Planning and conducting formative and summative evaluations.

In a previous study the first four types of knowledge and skills were addressed (Huizinga, Handelzalts, Nieveen, \& Voogt, accepted). The current study focuses on the expertise needed for implementation and evaluation activities (5 and 6).

\subsubsection{Expertise required for implementation}

Curriculum implementation is the process of using the new ideas and materials in classroom practice (Fullan, 2007; Tamir, 2004). Conducting implementation activities is expected to result in classroom practices, which represent the original renewal ideas (Hall \& Hord, 2010; Remillard, 2005). However, contextual limitations and personal beliefs, attitudes and expertise may affect to what extent the original renewal ideas are applied in practice by teachers (Remillard, 2005).

Based on a literature review, the expertise and the accompanying activities needed for conducting the implementation phase of a curriculum design process have been identified (see Table 4.1). 
Table 4.1 Expertise needed for conducting implementation (activities)

\begin{tabular}{|c|c|}
\hline Expertise & Activities to use and practice expertise \\
\hline Enhancing ownership & $\begin{array}{l}\text { - Involving stakeholders while designing } \\
\text { - Collaborative preparation of classroom use } \\
\text { - Discussing pedagogy } \\
\text { Reflecting on experiences }\end{array}$ \\
\hline Managing implementation processes & $\begin{array}{l}\text { - Planning implementation process } \\
\text { - Monitoring implementation }\end{array}$ \\
\hline Sharing experiences & $\begin{array}{l}\text { - Piloting designed curricula and reflecting on } \\
\text { experiences } \\
\text { - Offering curricular programs and exemplary } \\
\text { materials to teachers outside TDT } \\
\text { - Offering guidance to teachers outside TDT }\end{array}$ \\
\hline
\end{tabular}

Enhancing ownership. Teachers as designers are expected to know the importance of and how to foster ownership (e.g., Kessels \& Plomp, 1999), because without ownership a curriculum reform will not be implemented or implemented in a manner which undermines the rationale and goal of the renewal. Therefore, relevant stakeholders, such as school's management and colleague teachers outside the TDT, need to be identified and involved in design processes from an early stage (Kessels \& Plomp, 1999). By involving stakeholders the new curriculum can be aligned with stakeholders' wishes, needs and expectations.

Collaboratively planning the classroom usage of the new curriculum fosters teacher ownership (e.g., Penuel et al., 2007), especially when the teacher role, teacher-student interaction and practical issues are discussed. Moreover, identifying the differences between teachers' current practice and the new curriculum fosters teachers' understanding of the new curriculum.

Reflecting on classroom implementation offers opportunities to determine if the new curriculum is implemented as intended. It helps teachers to understand the relevance and importance of the new curriculum (Simmie, 2007). Furthermore, the insights can be used to improve the new curriculum and to determine its effectiveness.

Managing implementation processes. From the early stages of curriculum design, implementation of the curriculum reform needs to be managed. Carefully planning when to implement what by who helps to guide the design process. The planning describes the goal and scope of the implementation process, and when to involve experts and stakeholders (e.g., Richey et al., 2001). 
TDTs need to monitor the progress to identify to what extent the new curriculum is implemented in practice. Reflecting on the experiences with the new curriculum may result in revising or adjusting the planning.

Sharing experiences throughout the process fosters classroom implementation (Handelzalts, 2009). Piloting newly designed curricula and reflecting on the experiences enhances teachers' understanding of the new curriculum, especially when experiences are shared with colleagues (Hall \& Hord, 2010).

Providing curricular programs and exemplary materials helps to improve teachers' understanding of the new curriculum. Exemplary materials represent the reform ideas and are directly usable in practice (Van den Akker \& Voogt, 1994), which shed light on how the reform can be operationalised in practice.

Finally, guiding teachers to develop a shared understanding of the renewal fosters classroom implementation. Guidance can be offered by demonstrating the new curriculum (e.g., by offering an exemplary lesson or video examples), and through collegial preparation, implementation and reflection on the use of the new curriculum (Hall \& Hord, 2010).

\subsubsection{Expertise required for evaluation}

Evaluation refers to the process of determining the worth and merit of a curriculum (Scriven, 1991). Formative evaluations help to identify the aspects that require improvement. Summative evaluations aim to determine the effectiveness of the new curriculum, for example in terms of student learning (Scriven, 1991). Evaluations can address the product (curriculum) or the design process. Product evaluations identify the consistency, relevance, practicality and effectiveness of the curriculum materials (Nieveen, 2009). Process evaluations address the decisions made, the implementation process and the collaboration within the team.

Based on a review of the literature the expertise needed for conducting the evaluation phase (and accompanying activities) of a curriculum design process have been identified (see Table 4.2). 
Table 4.2 Expertise needed for conducting evaluation activities

\begin{tabular}{|c|c|}
\hline Expertise & Activities to use and practice expertise \\
\hline $\begin{array}{l}\text { Planning, structuring and } \\
\text { carrying out evaluations }\end{array}$ & $\begin{array}{l}\text { - Planning formative and summative evaluations } \\
\text { - Planning product and process evaluations } \\
\text { Developing evaluation instruments }\end{array}$ \\
\hline $\begin{array}{l}\text { Quality criteria and activities for } \\
\text { evaluating products }\end{array}$ & $\begin{array}{l}\text { - Identifying and determining relevance, } \\
\text { consistency, practicality and effectiveness } \\
\text { - Variety in carrying out evaluation activities }\end{array}$ \\
\hline $\begin{array}{l}\text { Analysing outcomes and improving } \\
\text { curriculum }\end{array}$ & $\begin{array}{l}\text { - Interpreting outcomes of evaluations } \\
\text { - Creating overview of aspects to improve }\end{array}$ \\
\hline
\end{tabular}

For planning, structuring and carrying out formative and summative evaluations teachers have to be able to formulate evaluation goals, develop instruments, collect data, analyse the data and interpret the results (e.g., Cochran-Smith \& Lytle, 2009; Huizinga, 2009; Schildkamp et al., submitted). It is desirable that teachers plan and conduct formative and summative evaluations as part of the design process to guarantee the quality of the new curriculum.

To conduct evaluations teachers as designers need instruments, either already available or newly developed (Richey et al., 2001). The focus of the evaluation (formative-summative, process-product, phase in the design process) influences the kind and the focus of instruments needed (Nieveen, 2009). Teachers as designers need to be able to link the instruments to the evaluation goals.

Quality criteria and activities for evaluating products. Teachers as designers are expected to have an understanding on how to assess the consistency, relevance, practicality and effectiveness of the designed curriculum (Nieveen, 2009; Richey et al., 2001). Therefore they are expected to assess each quality aspect and apply various evaluation methods, since this offers additional insights of the aspects that require improvement. However, previous studies showed that teachers as designers often do not conduct systematic evaluation activities (Handelzalts, 2009; Kerr, 1981).

Analysing outcomes and improving curriculum. The gathered evaluation data needs to be analysed and interpreted (Schildkamp et al., submitted). Teachers as designers identify the elements of the new curriculum, which require improvement. After analysing the outcomes, they determine how to improve the curriculum and who will make the changes (Richey et al., 2001). 


\subsection{RESEARCH DESIGN}

A qualitative case study method was applied (Yin, 2003). Within each case (a TDT), teachers (members of the TDT) used the CEFR-proof curriculum materials their TDT designed in the first stage of the project in their classrooms. All activities conducted by the TDTs and its members to prepare and use the new CEFR-proof curriculum materials (i.c. language tasks, assessment rubrics and school-specific adaptations of CEFR on teacher role and student activities) in practice are addressed as implementation activities. Evaluation activities relate to activities the TDT and its members conducted to determine the worth and merit of the language tasks and assessments rubrics. Within the cases (a TDT), the teachers are the unit of analysis.

\subsubsection{Case selection}

TDTs from the CEFR-project were selected that 1. integrated CEFR in their foreign language curriculum; 2. created language tasks (and rubrics) during the analysis and design stage, and 3. planned to use the new curriculum in their classrooms. Three cases (out of 15) were selected for this study. The characteristics of these TDTs are presented in Table 4.3.

Table 4.3 Characteristics of the selected cases

\begin{tabular}{|c|c|c|c|}
\hline Case & Plato & Thales & Othello \\
\hline $\begin{array}{l}\text { Involved } \\
\text { courses }\end{array}$ & $\begin{array}{l}\text { English, German, French } \\
\text { Spanish }\end{array}$ & English, German & English, German \\
\hline $\begin{array}{l}\text { Number of } \\
\text { foreign } \\
\text { language } \\
\text { teachers in } \\
\text { TDT }\end{array}$ & 5 of the 16 teachers & All 16 teachers & All 6 teachers \\
\hline $\begin{array}{l}\text { Foreign } \\
\text { language } \\
\text { teachers with } \\
\text { design } \\
\text { experience }\end{array}$ & 5 teachers & 8 teachers & 3 teachers \\
\hline Coordinator & German teacher & English teacher & German teacher \\
\hline $\begin{array}{l}\text { Facilitator } \\
\text { (pseudonym) }\end{array}$ & Jill & Frank & Emily \& Jill \\
\hline
\end{tabular}

All participating TDTs received tailored support from facilitators, who were employed at the Netherlands Institute for Curriculum Development. They were 
curriculum developers, former language teachers, were familiar with CEFR and experienced in supporting TDTs. Othello's TDT was part of a greater community of schools and received guidance from two facilitators.

\subsubsection{Procedure and instrumentation}

Five instruments and one artefact were used (Table 4.4). The instruments were discussed within the research team for content validity (Yin, 2003). Collected data were used to 1. re-construct the activities of TDTs' implementation and evaluation activities (RQ1), 2. determine teachers' experiences of the TDTs' implementation and evaluation activities (RQ2), 3. determine the implementation and evaluation activities in teachers' own classrooms (RQ3), and 4. determine teachers' experiences with the classroom implementation and evaluation activities (RQ4).

Table 4.4 Data collection per research question

\begin{tabular}{|c|c|c|c|c|}
\hline & RQ1 & RQ2 & RQ3 & RQ4 \\
\hline $\begin{array}{l}\text { Storyline } \\
\text { with teachers } \\
\text { from TDT }\end{array}$ & $X$ & $x$ & $X$ & $x$ \\
\hline $\begin{array}{l}\text { Observation } \\
\text { of design } \\
\text { team } \\
\text { meetings }\end{array}$ & $X$ & & & \\
\hline $\begin{array}{l}\text { Classroom } \\
\text { observation }\end{array}$ & & & $X$ & \\
\hline $\begin{array}{l}\text { Interview } \\
\text { with } \\
\text { observed } \\
\text { teachers }\end{array}$ & & & $X$ & $X$ \\
\hline $\begin{array}{l}\text { Language } \\
\text { task of } \\
\text { observed } \\
\text { lessons } \\
\text { (artefact) }\end{array}$ & & & $x$ & \\
\hline $\begin{array}{l}\text { Reflective } \\
\text { interview } \\
\text { with } \\
\text { facilitator }\end{array}$ & $X$ & & & \\
\hline
\end{tabular}

Storyline method. To answer RQs 1-4 the storyline method was used. The storyline method helps teachers reflect on processes (Beijaard et al., 1999; Handelzalts, 2009). While reflecting, teachers also identify additional activities which their TDT or its members conducted. Based on a guiding question teachers draw a line in a 
coordinate system. The $x$-axis represented the time (in months) and the $y$-axis represented teachers' experiences on a five point scale ranging from very negative (1) to very positive (5). Teachers individually draw a storyline and afterwards each teacher individually clarified (changes in) the line. Next, differences and commonalties are identified and clarified. Teachers reflected on the implementation and evaluation activities of the TDT and in their own classroom, guided by the questions: "How did you experience the design process as conducted within the TDT?" and "How did you experience the classroom implementation of the CEFR-proof curriculum materials?" While introducing the storyline method, the researcher emphasised to reflect on implementation and evaluation activities. The reflection about TDT's process was supported by providing the teachers an overview of the conducted activities. The storyline method was expanded with a semi-structured group interview to identify support offered to TDTs (Huizinga et al., accepted). Transcriptions and summaries were made and summaries were sent for member check (Merriam, 1988).

Observation checklist TDT meetings. To answer RQ1 the observation checklist of Huizinga et al. (accepted) was adapted to identify TDTs' implementation and evaluation activities. The checklist addressed the conducted activities, teachers' reactions during these activities, teachers' questions as raised during the meetings (and facilitators' response if applicable), articulated concerns related to the activities, and the contextual setting in which the meeting was organised.

Semi-structured interview facilitator. To answer RQ1 a semi-structured with the facilitator was administered to identify the characteristics of support offered to TDTs during the implementation and evaluation phase. These insights were used to identify and triangulate the TDTs' implementation and evaluation activities.

Observation checklist classroom observation. To answer RQ3, an observation checklist was developed, which checked the lesson activities, teacher's role during the lesson activities, student-teacher interaction and the context in which the lesson was conducted.

Semi-structured interview teachers. To answer RQ4, a semi-structured interview was used. The interview addressed teachers' experiences of the observed lesson, to what extent the observed lesson could be compared with other CEFR lessons and the (need for) support to carry out implementation and evaluation activities. 
Language task. To answer RQ3, the language tasks of the observed lessons were analysed to identify the intended curriculum (e.g., CEFR proficiency level, learning activities). These insights were compared with the classroom observations to identify if changes were made by the teachers when using the language tasks in practice.

\subsubsection{Data analysis}

All qualitative data were analysed using 'a priori' coding (Strauss \& Corbin, 1998). This data analysis technique prescribes that a codebook is based on the theoretical framework. While analysing, the codes are linked to (parts of) the data. Inductive coding was applied to find additional themes related to the implementation and evaluation process and teachers' experiences. Table 4.5 is a part of the final codebook.

Table 4.5 Section of the final codebook

\begin{tabular}{|c|c|}
\hline Level 1 & Description \\
\hline TDT-Implementation & $\begin{array}{l}\text { Implementation activity conducted by TDT (e.g., preparation of using } \\
\text { materials in practice) }\end{array}$ \\
\hline TDT-Evaluation & $\begin{array}{l}\text { Evaluation activity conducted by TDT (e.g., reflecting on use in } \\
\text { classroom) }\end{array}$ \\
\hline $\begin{array}{l}\text { TDT-Experience- } \\
\text { Implementation }\end{array}$ & $\begin{array}{l}\text { TDT member experience of conducted activity related to using CEFR } \\
\text { in the classroom }\end{array}$ \\
\hline $\begin{array}{l}\text { TDT-Experience- } \\
\text { Evaluation }\end{array}$ & $\begin{array}{l}\text { TDT member experience of conducted activity related to evaluating } \\
\text { the use of CEFR in the classroom }\end{array}$ \\
\hline $\begin{array}{l}\text { Classroom- } \\
\text { Implementation }\end{array}$ & Teachers' individual use of CEFR in the classroom \\
\hline Classroom-Evaluation & Evaluation activities conducted by individual teachers \\
\hline $\begin{array}{l}\text { Classroom-Experience- } \\
\text { Implementation }\end{array}$ & $\begin{array}{l}\text { Teachers' personal experience of using CEFR in his/her own } \\
\text { classroom }\end{array}$ \\
\hline $\begin{array}{l}\text { Classroom-Experience- } \\
\text { Evaluation }\end{array}$ & $\begin{array}{l}\text { Teachers' personal experience of carrying out evaluations related to } \\
\text { the use CEFR in his/her own classroom }\end{array}$ \\
\hline $\begin{array}{l}\text { Level } 2 \text { (example of } \\
\text { 'TDT-implementation') }\end{array}$ & Description \\
\hline Enhancing ownership & $\begin{array}{l}\text { Conducting activities to enhance ownership (e.g., collaborative } \\
\text { preparation of classroom use, involving stakeholders in design) }\end{array}$ \\
\hline $\begin{array}{l}\text { Managing } \\
\text { implementation process }\end{array}$ & $\begin{array}{l}\text { Conducting activities required for process management (e.g., } \\
\text { developing planning, monitoring progress) }\end{array}$ \\
\hline Sharing experiences & $\begin{array}{l}\text { Conducting activities in which experiences about the new curriculum } \\
\text { are shared (e.g., piloting the new curriculum, providing video } \\
\text { examples) }\end{array}$ \\
\hline
\end{tabular}


The researcher took the lead in the coding process. Quotes were selected and codes were assigned. First, quotes were related to TDT or classroom activities and the researcher identified if the quote illustrated teachers' experiences with the activities (level-1 code). For example, the quote "we have worked on it [implementation] [during the support meeting with all foreign language teachers]. Positive memories about it." was assigned the code "TDT-ExperienceImplementation". Second, the specific characteristic of the activity was identified (level-2 code). The exemplary quote was assigned with the level-2 code "enhancing ownership". Throughout the coding process, the application of codes was discussed in the research team until consensus was achieved.

\subsection{RESUlts}

\subsubsection{Case 1 - Plato's implementation and evaluation process}

\section{General description}

During the analysis and design stage, Plato's TDT (5 of the 16 foreign language teachers) developed language tasks (e.g., about dining in a restaurant), assessment rubrics (determining students' proficiency level of the specific language skills) and new examination guidelines for the foreign languages. They discussed whether and how CEFR would affect their pedagogy (e.g., teachers' role and student activities). Plato's TDT received just-in-time support, which was aligned with the TDT's progress in the design process, from Jill (facilitator) (Huizinga et al., accepted). The implementation and evaluation stage started when all 16 foreign language teachers attended a support meeting in which the new curriculum was introduced and discussed.

\section{Plato's TDT implementation and evaluation activities}

The implementation began at the start of the 2011-2012 school year ( $1^{\text {st }}$ month in Table 4.6) and lasted till December 2012. The chronological overview of the implementation and evaluation activities is provided in Table 4.6.

Plato's TDT involved their fellow colleagues during support meetings on classroom implementation of CEFR in the $1^{\text {st }}$ and $11^{\text {th }}$ month. TDT members shared their experiences with CEFR and discussed the pedagogy by offering an exemplary lesson to their fellow teachers. All 16 teachers discussed to what extent 
they wanted to apply the pedagogy in their practice (enhancing ownership, sharing experiences). In addition, Plato's TDT monitored the progress of using the language tasks during the $14^{\text {th }}$ month (managing implementation processes). During the closing meeting of the CEFR-project (14 ${ }^{\text {th }}$ month), Plato's TDT presented the outcomes of their design and implementation process to teachers from other schools (sharing experiences).

Table 4.6 Plato's TDT implementation and evaluation activities

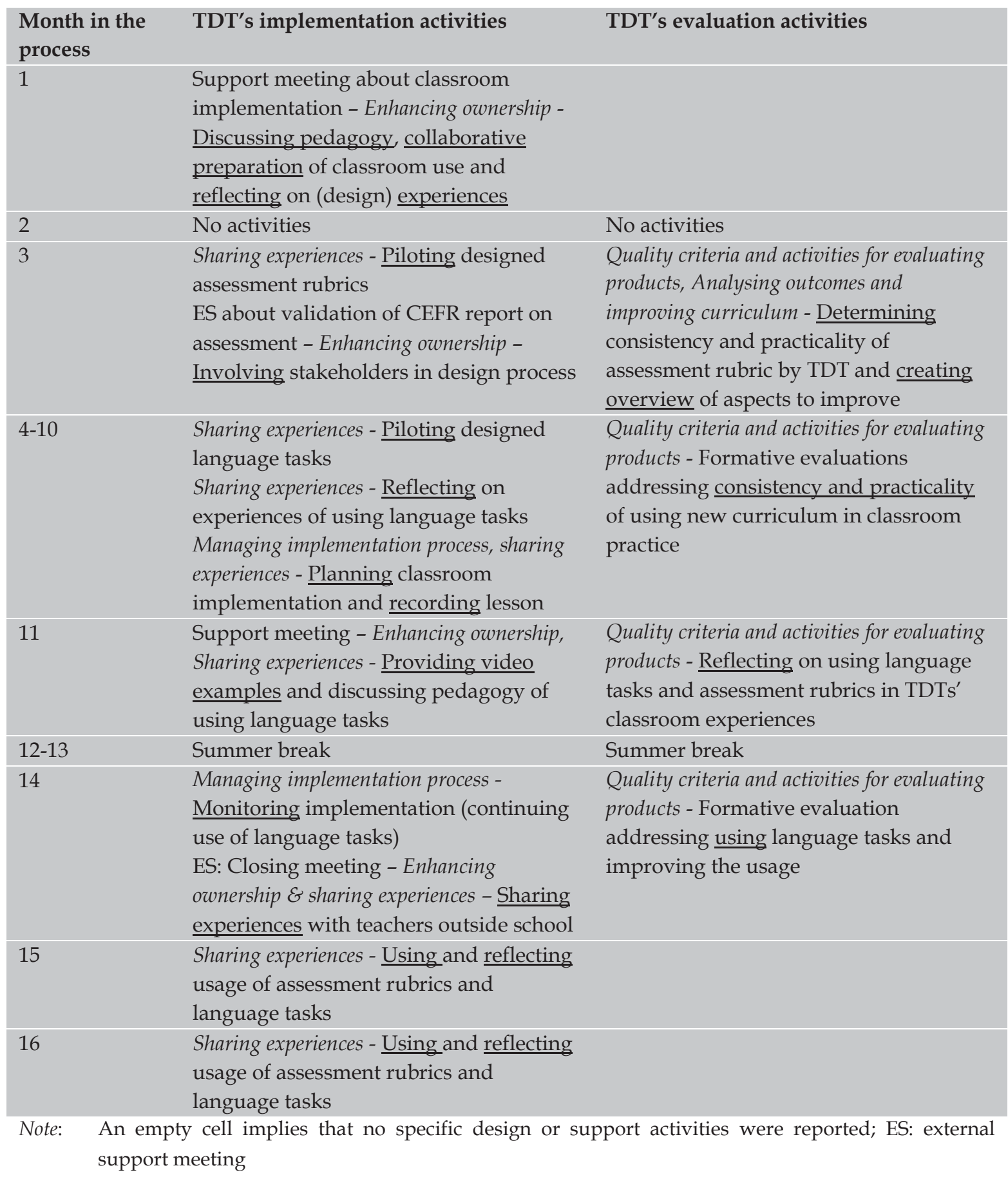


Plato's TDT organised formative evaluations during the CEFR-project to improve the language tasks and assessment rubrics (planning, structuring and carrying out evaluations). During these evaluations, they emphasised the practicality and consistency of the assessment rubrics and language tasks, which were identified by reflecting on classroom usage (quality criteria and activities for evaluating products). Plato's TDT discussed how to improve the curriculum materials. In general, they directly improved the designed materials or discussed who was responsible for improving the materials (analysing outcomes and improving curriculum).

\section{Plato's TDT members' experiences of TDTs' implementation and evaluation activities}

Five members reflected on the implementation and evaluation activities. In their reflections, the members also addressed the external support activities. Each team member (e.g., PTMA refers to Plato Team Member A) individually drew a storyline in a coordinate system (Figure 4.1; $\mathrm{x}$-axis represents month, y-axis represents teachers' experiences on a five-point scale). Since PTMD entered the meeting in which the storyline was conducted later, she only responded to her colleagues' reactions and did not clarify her own line.

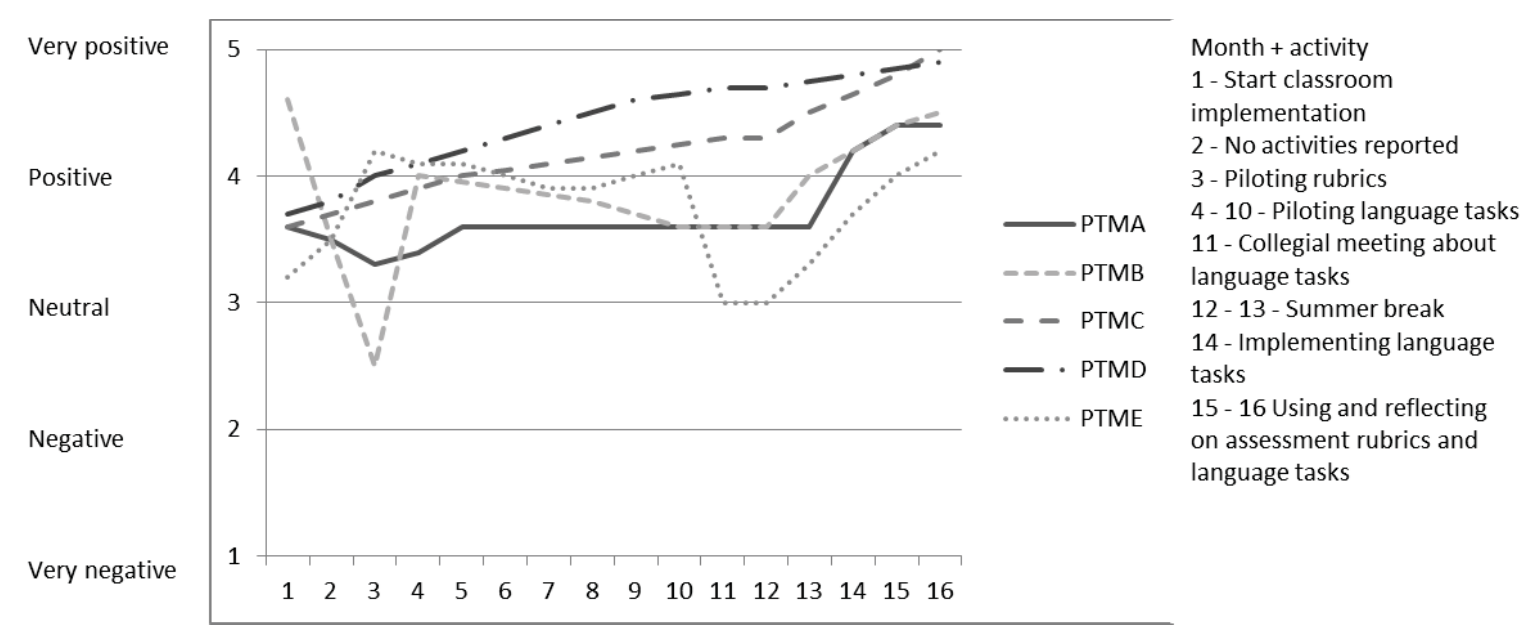

Figure 4.1 Storylines of Plato's team members about the TDT's implementation and evaluation activities

The meeting with all foreign language teachers in the $1^{\text {st }}$ month was positively valued by all members. Sharing insights of their design process and discussing the new pedagogical approach helped planning the classroom implementation. PTME appreciated that the discussions were closely related to classroom practice, 
which was confirmed by PTMA: "I had the feeling that our colleagues outside our group responded enthusiastically [...] We made some agreements [about using CEFR]".

Plato's TDT initiated piloting the assessment rubrics in the $3^{\text {rd }}$ month. They attended the validation of a CEFR-report on assessment, written by the facilitators, in which the quality of the report was discussed with foreign language teachers from schools in the CEFR-project. Whereas PTME found the validation "nice and interesting", PTMB's and PTMC's line descended; PTMB expected to receive support on how to implement CEFR instead of providing input to improve the report. In the same month, all foreign language teachers used the assessment rubrics to grade exams. Based on teachers' experiences, Plato's TDT planned and conducted two evaluations (3rd, $4^{\text {th }}$ month). They reflected on the experienced problems and how to tackle these problems. PTMC and PTME overcame their negative experience of the validation of the report, which resulted in an upward trend. The combination of the meeting with colleagues in the $1^{\text {st }}$ month and the follow-up activities fostered the implementation of the new curriculum within their school according to PTMC.

Until the summer break $\left(12^{\text {th }}, 13^{\text {th }}\right.$ month), Plato's TDT used the developed rubrics and language tasks in the classroom. They recorded lessons and shared their experiences with their colleagues outside the TDT, which was according to PTMC essential for using the new curriculum. At the end of the CEFR-project, PTMB and PTMD reported a downward trend, since new projects interfered with the CEFR implementation.

\section{Classroom implementation and evaluation in Plato}

Plato's TDT started using language tasks in the $4^{\text {th }}$ month of the implementation process. In the $14^{\text {th }}$ month (new school year) the first author conducted observations. Teachers reported that the observed lessons were comparable with other lessons in which they used language tasks.

Teachers used the language tasks they had designed in the TDT. Only PTMB did not use a language task, but posed questions in French about a book. Actively using the foreign language skills is one of the core aspects of CEFR, especially when applied in an authentic (simulated) context. The main characteristics of the observed lessons are provided in Table 4.7. 
Table 4.7 Characteristics of the implemented lessons in Plato

\begin{tabular}{|c|c|c|c|c|c|}
\hline $\begin{array}{l}\text { Lesson } \\
\text { characteristic }\end{array}$ & $\begin{array}{l}\text { PTMA's } \\
\text { lesson }\end{array}$ & $\begin{array}{l}\text { PTMB's } \\
\text { lesson }\end{array}$ & $\begin{array}{l}\text { PTMC's } \\
\text { lesson }\end{array}$ & $\begin{array}{l}\text { PTMD's } \\
\text { lesson }\end{array}$ & $\begin{array}{l}\text { PTME's } \\
\text { lesson }\end{array}$ \\
\hline Aim & $\begin{array}{l}\text { Practicing } \\
\text { conversations }\end{array}$ & $\begin{array}{l}\text { Practicing } \\
\text { conversations }\end{array}$ & $\begin{array}{l}\text { Practicing } \\
\text { conversations }\end{array}$ & $\begin{array}{l}\text { Practicing } \\
\text { conversations }\end{array}$ & $\begin{array}{l}\text { Practicing } \\
\text { conversation }\end{array}$ \\
\hline $\begin{array}{l}\text { Grouping (of } \\
\text { students) }\end{array}$ & Pairs & Whole class & Pairs & Four students & Pairs \\
\hline $\begin{array}{l}\text { Curriculum } \\
\text { materials }\end{array}$ & $\begin{array}{l}\text { Printed } \\
\text { language task } \\
\text { and } \\
\text { assessment } \\
\text { rubric }\end{array}$ & Textbook & $\begin{array}{l}\text { Printed } \\
\text { language task } \\
\text { and route } \\
\text { description } \\
\text { required to } \\
\text { complete task } \\
\text { (in Dutch) }\end{array}$ & $\begin{array}{l}\text { Printed } \\
\text { language task }\end{array}$ & $\begin{array}{l}\text { Printed } \\
\text { language task, } \\
\text { dictionary }\end{array}$ \\
\hline Teacher role & $\begin{array}{l}\text { Instructor at } \\
\text { start, mainly } \\
\text { coach }\end{array}$ & Coach & Coach & Coach & Coach \\
\hline Student activities & $\begin{array}{l}\text { Speaking in } \\
\text { pairs for at } \\
\text { least } 5 \\
\text { minutes and } \\
\text { recording the } \\
\text { conversation }\end{array}$ & $\begin{array}{l}\text { Answering } \\
\text { questions } \\
\text { posed by } \\
\text { teacher }\end{array}$ & $\begin{array}{l}\text { Speaking in } \\
\text { pairs for at } \\
\text { least } 10 \\
\text { minutes and } \\
\text { recording the } \\
\text { conversation } \\
\text { Reflecting } \\
\text { with teacher } \\
\text { at the end of } \\
\text { the lesson }\end{array}$ & $\begin{array}{l}\text { Practicing } \\
\text { speaking for } 4 \\
\text { minutes } \\
\text { Speaking in } \\
\text { pairs and } \\
\text { recording } \\
\text { conversation }\end{array}$ & $\begin{array}{l}\text { Preparing } \\
\text { conversation } \\
\text { and practicing } \\
\text { speaking. }\end{array}$ \\
\hline Student role & $\begin{array}{l}\text { Speaking to } \\
\text { peer-student }\end{array}$ & $\begin{array}{l}\text { Speaking to } \\
\text { teacher }\end{array}$ & $\begin{array}{l}\text { Speaking to } \\
\text { peer-student }\end{array}$ & $\begin{array}{l}\text { Speaking to } \\
\text { peer-student }\end{array}$ & $\begin{array}{l}\text { Preparing } \\
\text { conversations } \\
\text { in pairs }\end{array}$ \\
\hline Spoken language & $\begin{array}{l}\text { English } \\
\text { (students also } \\
\text { spoke native } \\
\text { language) }\end{array}$ & $\begin{array}{l}\text { French } \\
\text { (sometimes } \\
\text { native } \\
\text { language) }\end{array}$ & $\begin{array}{l}\text { German } \\
\text { (sometimes } \\
\text { native } \\
\text { language) }\end{array}$ & $\begin{array}{l}\text { English } \\
\text { (students also } \\
\text { spoke native } \\
\text { language) }\end{array}$ & $\begin{array}{l}\text { French } \\
\text { (students also } \\
\text { spoke native } \\
\text { language) }\end{array}$ \\
\hline
\end{tabular}

In all observed lessons the emphasis was on practicing speaking in conversations (aim). In general, except PTMB's lesson, students spoke the foreign language to each other in pairs or groups of four (grouping). Furthermore, additional materials, such as dictionaries or novels, were used in order to complete the task (curriculum materials). Teachers coached their students by helping to structure students' work. Students could pose questions required to complete the task. They received just-in-time support to tackle practical problems (e.g., computerrelated problems) and language issues (e.g., translating words or sentences). In PTME's lesson support addressed the creation of an outline for the conversation, 
whereas PTMB answered the questions students raised (teacher role). Both the native language (Dutch) and the foreign language were spoken by teachers and students (spoken language).

PTMA and PTMC asked their students to provide feedback on the language task and the specific activities included in these tasks at the end of the lesson (carrying out evaluation).

\section{Plato's teachers' experiences with classroom implementation and evaluation}

PTMA and PTMC experienced that the planned lessons were slightly different than the enacted lessons, since some activities required more time. Yet the overall goal of the lesson was still achieved. PTME reported that the time to prepare the conversations was too limited, and, therefore, gave her students additional time to complete this activity. PTMB's and PTMD's lesson were conducted as intended.

PTMA, PTMC and PTME felt unsure about the extent of guidance teachers were supposed to give their students in the learning process. According to PTMA discussions and exemplary videos might offer some insights, but in the end using and experiencing the new curriculum provided the most relevant insights (sharing experiences, teacher role). PTMB felt that the available time affected to what extent she used the foreign language. She realised that it decreased the lesson's pace and questioned when to switch to the native language (classroom experience, aim). No specific guidelines were provided for the implementation and, therefore, actual implementation depended on teachers' perceptions regarding their role and those of their students (classroom experience).

Reflecting on the overall progress of classroom implementation, teachers reported that they became more experienced with using language tasks. They indicated that before using the language tasks, tasks were evaluated by offering collegial feedback (carrying out evaluations). Furthermore, PTMA's and PTMD's students wrote a written report in which they critically reflected on lessons and their own experiences (carrying out evaluations). PTMA and PTMB indicated that their highlight was the start of a new school year, since they actually started using the new curriculum in the classrooms and shared their experiences (sharing experiences). 


\subsubsection{Case 2 - Thales' implementation and evaluation process}

\section{General description}

During the analysis and development stage, Thales' 16 foreign language teachers received support to systematically design language tasks. Four teachers developed a vision document in which the core elements of their new curriculum were described (Huizinga et al., accepted). These teachers discussed whether and how the new curriculum would affect the strategies for teaching. At the start of the implementation, all foreign language teachers attended a support meeting in which the essence of formative evaluations was discussed by Frank (facilitator).

\section{Thales' implementation and evaluation activities}

In May 2012 the implementation process started (1 $1^{\text {st }}$ month in Table 4.8$)$ and lasted until December 2012. The chronological overview of the implementation and evaluation activities is provided in Table 4.8 .

From the early stages of the process, Thales' coordinator scheduled support meetings and the overall progress of the process was monitored. The progress was discussed with all teachers which resulted in a new planning (managing the implementation process).

Thales' teachers collaboratively planned the classroom implementation and planned the pilots of language task. During a meeting in the $5^{\text {th }}$ month, teachers decided whether to design new exams or language tasks. Moreover, teachers exchanged their experiences with using language tasks to inspire fellow teachers how to use such tasks in practice (enhancing ownership). During the closing meeting of the CEFR-project ( $6^{\text {th }}$ month), experiences were shared with teachers outside the school by presenting the outcomes of their design and implementation process (sharing experiences).

In the $1^{\text {st }}$ month, Thales' teachers attended a support meeting in which the importance of conducting evaluations was discussed. Frank introduced the quality criteria, illustrated evaluation methods and provided an observation instrument. Despite the support, none of the teachers planned or conducted evaluations in the subsequent months (planning, structuring and carrying out evaluations; quality criteria and activities for evaluating products). 
Table 4.8 Chronological overview of the implementation and evaluation activities in Thales

\begin{tabular}{|c|c|c|}
\hline $\begin{array}{l}\text { Month in the } \\
\text { process }\end{array}$ & TDT's implementation activities $^{1,2}$ & TDT's evaluation activities \\
\hline 1 & $\begin{array}{l}\text { ES: Meeting about formative evaluation - } \\
\text { Managing implementation process - } \\
\text { Planning implementation process } \\
\text { ES: Meeting about formative evaluation - } \\
\text { Enhancing ownership - Reflecting on using } \\
\text { language task }\end{array}$ & $\begin{array}{l}\text { ES: Meeting about formative evaluation - } \\
\text { Planning, structuring and carrying out } \\
\text { evaluations \& Quality criteria and activities } \\
\text { for evaluating products - Learning about } \\
\text { quality criteria and possible (formative) } \\
\text { evaluation activities }\end{array}$ \\
\hline 2 & $\begin{array}{l}\text { ES: meeting about student assessment - } \\
\text { Enhancing ownership - Discussing } \\
\text { pedagogy (assessing language skills) }\end{array}$ & \\
\hline 3 & Summer break & Summer break \\
\hline 4 & Summer break & Summer break \\
\hline 5 & $\begin{array}{l}\text { Managing implementation process - } \\
\text { Monitoring implementation process } \\
\text { (progress) } \\
\text { Managing implementation process - } \\
\text { Collaborative planning of piloting/using } \\
\text { language tasks }\end{array}$ & \\
\hline 6 & $\begin{array}{l}\text { ES: Closing meeting - Enhancing } \\
\text { ownership \& sharing experiences - Sharing } \\
\text { experiences with teachers outside school } \\
\text { Sharing experiences - Piloting language } \\
\text { tasks }\end{array}$ & \\
\hline 7 & $\begin{array}{l}\text { Sharing experiences - Piloting language } \\
\text { tasks }\end{array}$ & \\
\hline 8 & $\begin{array}{l}\text { Sharing experiences - Piloting language } \\
\text { tasks }\end{array}$ & \\
\hline Not & $\begin{array}{l}\text { ty cell implies that no specific design o } \\
\text { meeting }\end{array}$ & $\mathrm{s} w$ \\
\hline
\end{tabular}




\section{Thales' TDT members' experiences of TDTs' implementation and evaluation activities}

Three teachers reflected on the implementation and evaluation activities which were conducted in Thales, including the support activities (Figure 4.2).

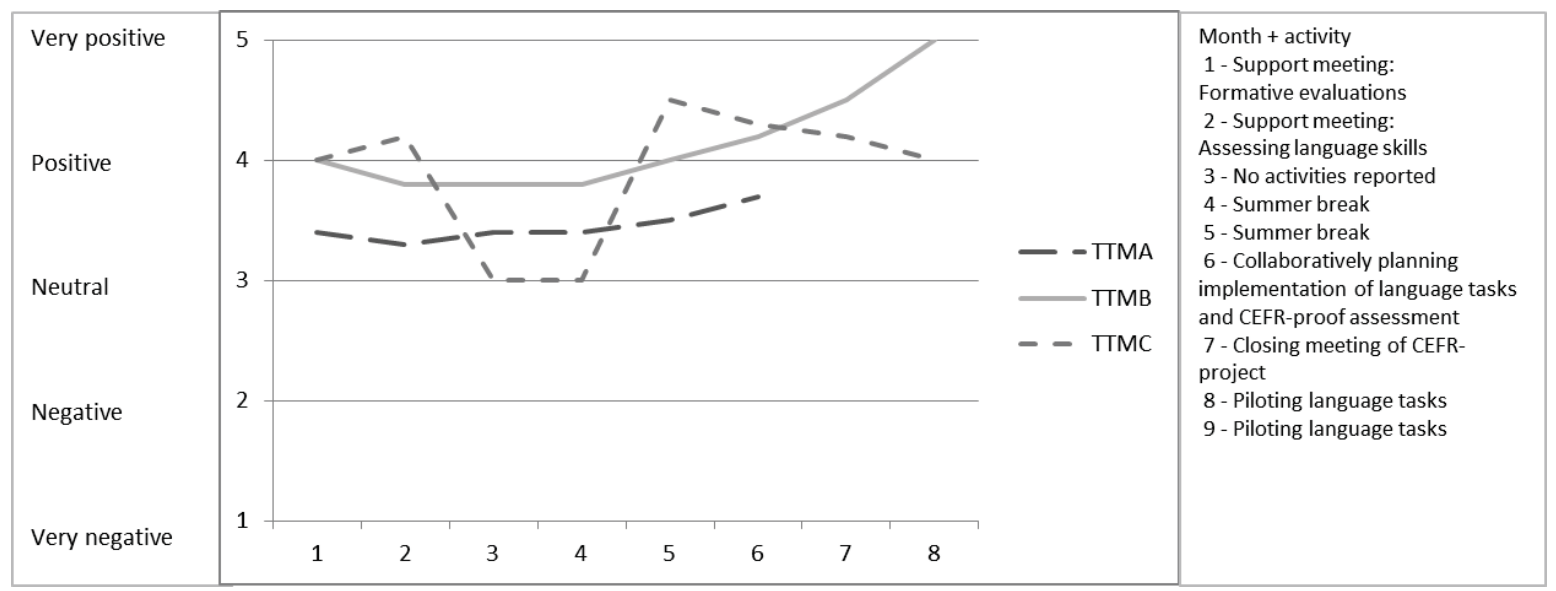

Figure 4.2 Storylines of the implementation and evaluation process by Thales' TDT

Using the new curriculum materials resulted in an overall upward trend in TTMB's line (coordinator), since she realised: "now we are working with language tasks and assessment and I have to make myself clear that we are doing a lot of good things." TTMC's line also showed an overall positive trend, since he learned to "think in chances, in terms of what are the opportunities."

Teachers positively valued the support meeting (1 ${ }^{\text {st }}$ month). TTMA expressed "[the] presentations offered by Frank [were] useful. [...]. Translating to practice remains difficult." The discussion Thales' lead TDT had during the development of the vision document were "more meaningful [to change practice]" according to TTMA.

After the summer break, teachers divided the activities required for designing language tasks and assessment rubrics. Attending and presenting the outcomes of their progress during the closing meeting of the CEFR-project resulted in an upward trend for TTMC, since she realised that their TDT had "really, really accomplished a lot." 


\section{Thales' teachers' classroom implementation and evaluation activities}

Teachers started using language tasks from the $5^{\text {th }}$ month (new school year). The first author observed three teachers, from which one (TTMB) was observed twice. Teachers reported that they provided some additional instruction during the observed lessons than during regular lessons.

The teachers used the language tasks they had designed, which were based on the core aspects of CEFR. The main characteristics of the observed lessons are provided in Table 4.9.

Table 4.9 Characteristics of the implemented lessons in Thales

\begin{tabular}{|c|c|c|c|c|}
\hline $\begin{array}{l}\text { Lesson } \\
\text { characteristics }\end{array}$ & TTMA's lesson & TTMB's lesson (1) & TTMB's lesson (2) & TTMD's lesson \\
\hline Aim & $\begin{array}{l}\text { Practicing all } \\
\text { language skills }\end{array}$ & $\begin{array}{l}\text { Practicing } \\
\text { conversations }\end{array}$ & $\begin{array}{l}\text { Practicing } \\
\text { conversations }\end{array}$ & $\begin{array}{l}\text { Practicing writing } \\
\text { skills }\end{array}$ \\
\hline $\begin{array}{l}\text { Grouping (of } \\
\text { students) }\end{array}$ & Four students & All students & All students & All students \\
\hline $\begin{array}{l}\text { Curriculum } \\
\text { materials }\end{array}$ & $\begin{array}{l}\text { Printed language } \\
\text { tasks }\end{array}$ & $\begin{array}{l}\text { Printed language } \\
\text { tasks }\end{array}$ & $\begin{array}{l}\text { Printed language } \\
\text { tasks }\end{array}$ & $\begin{array}{l}\text { Printed language } \\
\text { tasks }\end{array}$ \\
\hline Teacher role & $\begin{array}{l}\text { Instructor (at start } \\
\text { to introduce task), } \\
\text { coach (while } \\
\text { students worked } \\
\text { on tasks) }\end{array}$ & Instructor & Instructor & Instructor \\
\hline Student activities & $\begin{array}{l}\text { Reading tasks, } \\
\text { dividing activities } \\
\text { required to } \\
\text { complete tasks }\end{array}$ & $\begin{array}{l}\text { Listening to } \\
\text { instruction and } \\
\text { posing questions }\end{array}$ & $\begin{array}{l}\text { Listening to } \\
\text { instruction and } \\
\text { posing questions }\end{array}$ & $\begin{array}{l}\text { Listening to } \\
\text { instruction and } \\
\text { posing questions }\end{array}$ \\
\hline Student role & $\begin{array}{l}\text { Working in group } \\
\text { and dividing roles } \\
\text { to complete tasks }\end{array}$ & Passive role & Passive role & Passive role \\
\hline Spoken language & Native language & Native language & Native language & $\begin{array}{l}\text { Mainly native } \\
\text { language }\end{array}$ \\
\hline
\end{tabular}

In the observed lessons the emphasis was on one or several language skills (aim). In TTMA's lesson, students worked on the language tasks in groups of four (grouping), while being coached by TTMA who helped to structure the tasks (teacher role). In the other three lessons, the task was introduced by providing instruction to all students (teacher role, grouping). During all lessons, both the students and the teachers spoke the native language (spoken language). 


\section{Thales' teachers' experiences with classroom implementation and evaluation}

Teachers made some last-minute adaptations while implementing the lessons. TTMA removed one activity from the language task, since it was not required to complete the task. Furthermore, he offered additional instruction on writing a letter, since it was not well-explained in the textbook. TTMB offered more instruction, since she noticed that her students paid less attention due to excitement about other school-activities. In contrast, according to TTMD, her students were focused and posed relevant questions related to the instruction.

TTMA had concerns about the actual learning of the students and, therefore, intended to offer more guidance in the subsequent lessons. Moreover, TTDM indicated that she was planning to develop an exemplary final product to provide additional guidance to her learners (sharing experiences, teacher role). TTMD wanted to include additional pictures in the language tasks to improve the alignment with the students' expectations of learner materials (classroom experiences, curriculum materials).

Reflecting on classroom implementation, teachers were positive about what they had accomplished. Prior to classroom implementation, teachers had discussed the language tasks with their colleagues (carrying out evaluations). Furthermore, classroom experiences were used to improve the lessons, for example to prevent misinterpretations about the activities in the language tasks as TTMB did. To structure evaluations, TTMA expressed the need for a checklist to evaluate the tasks (quality criteria and activities for evaluating products). TTMA and TTMC positively experienced classroom implementation, as TTMC clarified, he realised he "already did some things according to CEFR in my lessons" (enhancing ownership, sharing experiences). Although the implementation was positively experienced, TTMA learned "You might think you just hand them a language tasks and they are going to work with it. [...] They cannot do it, since they drown [while working on the task]."

\subsubsection{Othello's implementation and evaluation process}

\section{General description}

During the analysis and design stage, Othello's TDT designed language tasks and discussed when and how to implement these tasks. In addition, one representative from Othello's TDT helped to prepare support meetings on CEFR which were organised for all foreign language teachers of Othello and other schools of the 
same school board. Newly developed assessment rubrics were introduced and the school's vision about speaking the foreign language was discussed. Support meetings were offered by two external facilitators (Emily and Jill), who also helped preparing the outline and offered workshops about CEFR and designing language tasks. At the start of the implementation process, Othello's TDT started using language tasks and the assessment rubrics.

\section{Othello's implementation and evaluation activities}

April 2012 marked the start of the implementation process. Othello's TDT planned, (re)designed, formatively evaluated and implemented one language task (the language village task). Furthermore, they started using the assessment rubrics in practice and piloted other language tasks. The chronological overview of Othello's implementation and evaluation activities is provided in Table 4.10.

Othello's TDT collaboratively (re)designed the language village task. The language village task consists of a variety of (short) activities in which the students speak the foreign language in a specific context (e.g., tourist information) in order to achieve a specific goal (e.g., ask for additional information about sightseeing). Teachers used their prior experiences with similar activities to create the language village task. Furthermore, they discussed how to implement the newly designed task in practice (enhancing ownership). Moreover, they decided when design, implementation and evaluation activities were conducted (managing implementation process).

During support meetings in the $3^{\text {rd }}, 6^{\text {th }}$ and $7^{\text {th }}$ month Othello's teachers illustrated to teachers outside their school how they used language tasks and shared the designed tasks (sharing experiences). In the $3^{\text {rd }}$ month, teachers collaboratively planned when to use the new assessment rubrics (enhancing ownership). During the closing meeting of the CEFR-project, Othello's TDT presented what they had achieved in the project. 
Table 4.10 Overview of the conducted activities in Othello during the implementation and evaluation phases

\begin{tabular}{|c|c|c|}
\hline $\begin{array}{l}\text { Month in } \\
\text { the process }\end{array}$ & TDT's implementation activities & TDT's evaluation activities \\
\hline 1 & $\begin{array}{l}\text { Support - enhancing ownership - } \\
\text { Collaborative preparation of assessment } \\
\text { rubrics }\end{array}$ & $\begin{array}{l}\text { ES: meeting about formative evaluation - } \\
\text { Planning, structuring and carrying out } \\
\text { evaluations \& Quality criteria and activities } \\
\text { for evaluating products - Learning about } \\
\text { quality criteria and possible (formative) } \\
\text { evaluation activities }\end{array}$ \\
\hline 2 & $\begin{array}{l}\text { Othello's TDT - enhancing ownership } \mathcal{E} \\
\text { managing implementation process - } \\
\text { Collaborative planning language village } \\
\text { Othello's TDT - enhancing ownership - } \\
\text { Collaboratively (re)designing language } \\
\text { village }\end{array}$ & $\begin{array}{l}\text { Othello's TDT - Quality criteria and } \\
\text { activities for evaluating products - } \\
\text { Determining practicality of language } \\
\text { village }\end{array}$ \\
\hline 3 & $\begin{array}{l}\text { Othello's TDT - Enhancing ownership \& } \\
\text { sharing experiences - Reflecting on using } \\
\text { language tasks and preparing pilot } \\
\text { Othello's TDT - Enhancing ownership \& } \\
\text { sharing experiences - Piloting language } \\
\text { village and reflecting on experiences } \\
\text { ES - Enhancing ownership \& sharing } \\
\text { experiences - Exchanging best-practices } \\
\text { with peers }\end{array}$ & $\begin{array}{l}\text { Support - Quality criteria and activities for } \\
\text { evaluating products - Determining } \\
\text { consistency and practicality of assessment } \\
\text { rubrics }\end{array}$ \\
\hline 4 & Summer break & Summer break \\
\hline 5 & Summer break & Summer break \\
\hline 6 & $\begin{array}{l}\text { Othello's TDT - Sharing experiences - } \\
\text { Piloting language tasks } \\
\text { Support - Managing implementation process } \\
\text { - Planning implementation process of } \\
\text { using language tasks } \\
\text { Support - Enhancing ownership - } \\
\text { Exchanging experiences and involving } \\
\text { colleagues in design of (new) language } \\
\text { tasks }\end{array}$ & $\begin{array}{l}\text { ES - Quality criteria and activities for } \\
\text { evaluating products - Determining } \\
\text { consistency and practicality (continuation } \\
\text { meeting } 3^{\text {rd }} \text { month) }\end{array}$ \\
\hline 7 & $\begin{array}{l}\text { ES: Closing meeting - Enhancing ownership } \\
\text { \& sharing experiences - Sharing experiences } \\
\text { with other teachers in the CEFR-project } \\
\text { Othello's TDT - Sharing experiences - } \\
\text { Piloting language tasks }\end{array}$ & \\
\hline 8 & $\begin{array}{l}\text { Othello's TDT - Sharing experiences - } \\
\text { Piloting language tasks }\end{array}$ & \\
\hline 9 & $\begin{array}{l}\text { Othello's TDT - Sharing experiences - } \\
\text { Piloting language tasks }\end{array}$ & \\
\hline Note: & $\begin{array}{l}\text { empty cell implies that no specific design } \\
\text { port meeting; Support: a meeting with teache }\end{array}$ & $\begin{array}{l}\text { upport activities were r } \\
\text { ttside their school }\end{array}$ \\
\hline
\end{tabular}


Othello's teachers organised formative evaluations to improve the language village task and assessment rubrics (planning, structuring and carrying out evaluations). During these evaluations, teachers determined whether the designed tasks suited their students. Othello's TDT emphasised on the practicality and consistency of the language tasks. Teachers collaboratively discussed the quality of the assessment rubrics using predetermined guidelines during support meetings (quality criteria and activities for evaluating products). Based on these reflections and discussions, the designed tasks and rubrics were improved (analysing outcomes and improving curriculum).

\section{Teachers' experiences of TDT's implementation and evaluation activities}

Five members of Othello's TDT reflected on the implementation and evaluation activities and their experiences with the external support (Figure 4.3). OTMD and OTME joined Othello later in the process, therefore, they only reflected on the months they were enrolled in the TDT.

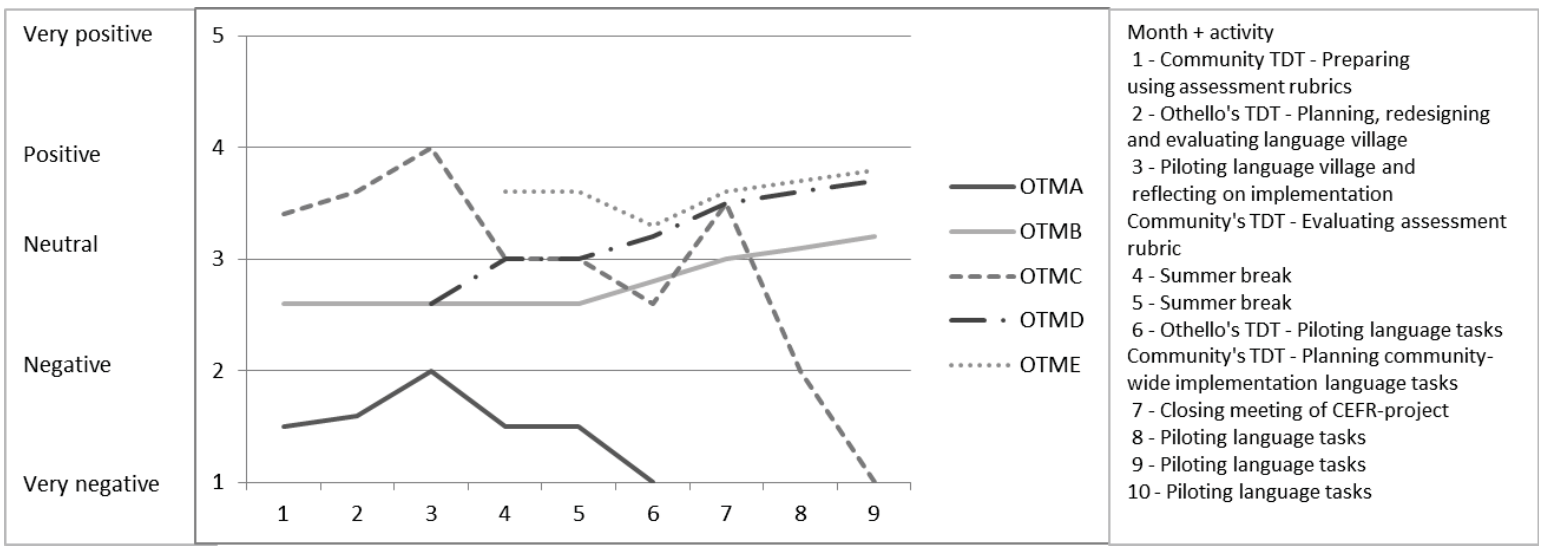

Figure 4.3 Storylines of the implementation and evaluation process by Othello's TDT

The teachers indicated that their reflections were heavily influenced by their experiences of the support meetings. OTMB felt disconnected from the support process, since "it [support activities] took place in 'another place'. That's why I start quite low." Also OTMA and OTMC experienced that the support was not aligned with their TDT's progress. OTMA clarified: "We [Othello's TDT] were pioneering. They [(external) support] did not align it [with the progress of Othello's TDT], which made the process not relevant." 
Implementing the language village tasks in the third month resulted in an upward trend for OTMA and OTMC. However, their lines descended again after this month due to the summer break.

OTMB felt disconnected from the process until the $6^{\text {th }}$ month and, therefore, reported a stable line. From the 6th month onwards, OTMB became more enthusiastic since he realised that "a lot of work is done [during support meetings and by the TDT]." OTMC's line showed an upward trend, since "everyone [Othello's teachers] was willing to make and use language tasks." OTME was positive about the received support from her colleagues, although during one support meeting in the $3^{\text {rd }}$ month CEFR was not addressed.

Attending the closing meeting in the $7^{\text {th }}$ month was positively experienced by OTMC and OTMD. According to OTMD: "It gave me a boost, since I compared myself with the other [teachers] and it fostered [the implementation of] my work." Sharing experiences and receiving new insights resulted in an upward trend in OTMC's line. It made OTMC aware of the progress they made during the CEFR-project.

During the last two months most teachers reported positive experiences regarding their implementation and evaluation activities. Only OTMC reported that due to all the workload she experienced her line descended.

\section{Othello's teachers' classroom implementation and evaluation activities}

Othello's teachers started using language tasks in the $3^{\text {rd }}$ month of the implementation process. Five lessons were observed by the first author. One teacher was observed twice (OTMB). Teachers reported that the observed lessons were comparable with other lesson in which they used language tasks.

During all lessons, language tasks used which Othello's TDT had designed. These tasks represented the core aspects of CEFR and during lessons Othello's teachers were expected to apply the new strategies for teaching and learning (e.g., applying an action-oriented approach for learning languages). Table 4.11 provides the main characteristics of the observed lessons. 
Table 4.11 Characteristics of the observed lessons in Othello

\begin{tabular}{|c|c|c|c|c|c|}
\hline $\begin{array}{l}\text { Lesson } \\
\text { characteristics }\end{array}$ & $\begin{array}{l}\text { Language } \\
\text { village1 }\end{array}$ & $\begin{array}{l}\text { OTMB's } \\
\text { lesson (1) }\end{array}$ & $\begin{array}{l}\text { OTMB's } \\
\text { lesson (2) }\end{array}$ & $\begin{array}{l}\text { OTMC's } \\
\text { lesson }\end{array}$ & $\begin{array}{l}\text { OTMF's } \\
\text { lesson }\end{array}$ \\
\hline Aim & $\begin{array}{l}\text { Assessment of } \\
\text { conversation }\end{array}$ & $\begin{array}{l}\text { Practicing } \\
\text { writing skills }\end{array}$ & $\begin{array}{l}\text { Practicing } \\
\text { conversation } \\
\text { skills }\end{array}$ & $\begin{array}{l}\text { Practicing } \\
\text { listening skills }\end{array}$ & $\begin{array}{l}\text { Practicing } \\
\text { writing and } \\
\text { conversation } \\
\text { skills }\end{array}$ \\
\hline $\begin{array}{l}\text { Grouping (of } \\
\text { students) }\end{array}$ & Pairs & $\begin{array}{l}\text { Individual } \\
\text { base }\end{array}$ & All students & $\begin{array}{l}\text { Individual } \\
\text { base }\end{array}$ & Pairs \\
\hline $\begin{array}{l}\text { Curriculum } \\
\text { materials }\end{array}$ & $\begin{array}{l}\text { Descriptions } \\
\text { of the aim of } \\
\text { each setting. }\end{array}$ & $\begin{array}{l}\text { Language } \\
\text { tasks (digital), } \\
\text { dictionaries. }\end{array}$ & Textbook & $\begin{array}{l}\text { Language } \\
\text { tasks, } \\
\text { dictionaries }\end{array}$ & $\begin{array}{l}\text { Language } \\
\text { tasks, } \\
\text { dictionaries }\end{array}$ \\
\hline Teacher role & $\begin{array}{l}\text { Coach and } \\
\text { assessor }\end{array}$ & Coach & Instructor & Coach & Coach \\
\hline $\begin{array}{l}\text { Student } \\
\text { activities }\end{array}$ & $\begin{array}{l}\text { Speaking in } \\
\text { pairs for at } \\
\text { least two } \\
\text { minutes per } \\
\text { setting }\end{array}$ & $\begin{array}{l}\text { Working } \\
\text { individually } \\
\text { on (completion } \\
\text { of) tasks }\end{array}$ & $\begin{array}{l}\text { Planning date } \\
\text { for assessment } \\
\text { (together with } \\
\text { teacher) } \\
\text { Checking } \\
\text { homework } \\
\text { assignments } \\
\text { Spoken } \\
\text { production } \\
\text { Individual } \\
\text { work on tasks } \\
\text { Receiving new } \\
\text { homework } \\
\text { assignments }\end{array}$ & $\begin{array}{l}\text { Working } \\
\text { individually } \\
\text { on } \\
\text { (completion } \\
\text { of) tasks }\end{array}$ & $\begin{array}{l}\text { Writing an } \\
\text { activity } \\
\text { overview } \\
\text { (schedule) } \\
\text { Listening to } \\
\text { teacher } \\
\text { Continuing } \\
\text { working on } \\
\text { activity } \\
\text { overview }\end{array}$ \\
\hline Student role & $\begin{array}{l}\text { Speaking to } \\
\text { peer-student } \\
\text { and teacher }\end{array}$ & Writing a flyer & $\begin{array}{l}\text { Speaking to } \\
\text { peer-student; } \\
\text { answering } \\
\text { questions } \\
\text { posed by } \\
\text { teacher. }\end{array}$ & $\begin{array}{l}\text { Listening and } \\
\text { interpreting } \\
\text { songs }\end{array}$ & $\begin{array}{l}\text { Writing of } \\
\text { activity } \\
\text { overview; } \\
\text { listening and } \\
\text { answering } \\
\text { questions }\end{array}$ \\
\hline $\begin{array}{l}\text { Spoken } \\
\text { language }\end{array}$ & $\begin{array}{l}\text { English (both } \\
\text { students and } \\
\text { teachers) }\end{array}$ & $\begin{array}{l}\text { Native } \\
\text { language (both } \\
\text { students and } \\
\text { teacher) }\end{array}$ & $\begin{array}{l}\text { Mainly native } \\
\text { language (both } \\
\text { students and } \\
\text { teacher), one } \\
\text { assignment in } \\
\text { German }\end{array}$ & $\begin{array}{l}\text { Native } \\
\text { language } \\
\text { (both students } \\
\text { and teacher) }\end{array}$ & $\begin{array}{l}\text { Mainly native } \\
\text { language } \\
\text { (both students } \\
\text { and teacher), } \\
\text { one } \\
\text { assignment in } \\
\text { German }\end{array}$ \\
\hline $\begin{array}{l}\text { Time spend on } \\
\text { language tasks } \\
\text { during } \\
\text { observation }\end{array}$ & $\begin{array}{l}10 \text { minutes (of } \\
50 \text { minutes) }\end{array}$ & $\begin{array}{l}\text { Whole lesson } \\
\text { (50 minutes) }\end{array}$ & $\begin{array}{l}0 \text { minutes (of } \\
50 \text { minutes) }\end{array}$ & $\begin{array}{l}\text { Whole lesson } \\
\text { (50 minutes) }\end{array}$ & $\begin{array}{l}\text { Whole lesson } \\
\text { (50 minutes) }\end{array}$ \\
\hline
\end{tabular}

In all observed lessons, except OMTB's $2^{\text {nd }}$ lesson, language tasks were used. In OTMB's $2^{\text {nd }}$ lesson students spoke the foreign language during one activity. In the 
other lessons, students used language tasks and planned their own learning (learner role). Teachers fulfilled the role of coach to help their students to tackle the experienced problems (teacher role). Teachers offered just-in-time support, which addressed solving practical issues (e.g., computer problems) and language related issues (e.g., translating words or providing suggestions). While supporting their students, teachers spoke the native language and hardly spoke the foreign language. Only during the language village, both teachers and students spoke the foreign language and had short conversations (spoken language).

\section{Othello's teachers' experiences with classroom implementation and evaluation}

OTMB and OTMC experienced that the students required more guidance and structure. OTMB noted it is hard to identify who is working on which task, since students determine their own pace. OTMC argued that language tasks have too much text and, therefore, students hardly read tasks and posed questions what they had to do. OTMF believed that the variation in student activities was too limited. He also realised that the prescribed time to complete the task was not sufficient, which he changed in the task. OTMC indicated that students experienced computer-related problems, such as uploading their language tasks in the electronic learning environment.

OTMB and OTMF indicated that additional discussions within the TDT were needed about the pedagogical approach and the teacher role (creating ownership, teacher role). OTMF questioned whether language tasks were intended for individual students or better suitable for working in pairs. Othello's teachers positively experienced classroom implementation, especially since they became more confident in using the language tasks and the new CEFR-curriculum (classroom experience). Othello's discussed the designed language tasks within the TDT (carrying out evaluations). OTMB improved one task based on prior experiences by replacing the final assignment to better align the task with the students (carrying out evaluations).

OTMB and OTMC argued that additional support was required to foster classroom implementation and evaluation. For example, OTMC required support to align the amount of text with her students (curriculum materials). Furthermore, she wanted to receive feedback from experts on the designed language tasks (carrying out evaluations). OTMB wanted support to improve and determine the effectivity of working with language tasks (carrying out evaluation). 


\subsection{CONCLUSION}

This study was set out to identify what implementation and evaluation activities conducted by TDTs provide opportunities to enhance teachers' curriculum design expertise. Therefore, conducted implementation and evaluation activities were identified and teachers reflected on their experiences with these activities, as initiated by TDTs and by themselves. These insights illustrate which implementation and evaluation activities teachers valued and found relevant for their process.

\subsubsection{TDTs' implementation and evaluation activities and corresponding experiences}

Table 4.12 provides the results of the cross-case analysis of the three TDTS. Based on the implementation activities carried out and teachers' reflections, it seems that within TDTs, the expertise was adequate to foster the implementation process. Furthermore, activities closely related to teachers' classroom practice, such as piloting assessment rubrics and language tasks, were especially valued by teachers (cf. Handelzalts, 2009; Huizinga et al., 2014, accepted).

Each TDT organised its own implementation process, implying that the kind and intensity of the activities between the three TDTs differed. All TDTs conducted activities in which experiences were shared, for example though exemplary materials or video examples. How experiences were shared depended on the TDT and the context in which the TDT was operating. Consequently, the opportunities for conducting and experiencing specific activities differed. In Plato not all foreign language teachers were part of the TDT. Therefore, Plato's TDT had to conduct additional activities to enhance ownership, for example by discussing the new pedagogy with their colleagues and providing exemplary materials. In Thales and Othello teachers shared experiences during collegial meetings by illustrating how they used a particular language task in practice. Teachers' reflections revealed that they acquired new ideas on how to use the new curriculum, which fostered the implementation (cf. Anto, 2013; Huizinga et al., accepted). However, teachers also indicated to struggle with translating the curriculum reform to their classroom practices and had concerns about the pedagogy. 
Table 4.12 TDTs' implementation and evaluation expertise

\begin{tabular}{|c|c|c|c|}
\hline Characteristics & Plato & Thales & Othello \\
\hline Duration of process & 16 months & 9 months & 9 months \\
\hline \multicolumn{4}{|l|}{$\begin{array}{l}\text { Implementation } \\
\text { knowledge and skills }\end{array}$} \\
\hline $\begin{array}{l}\text { - Enhancing } \\
\text { ownership }\end{array}$ & + & + & + \\
\hline $\begin{array}{l}\text { Managing } \\
\text { implementation } \\
\text { processes }\end{array}$ & - & $+/-$ & $+/-$ \\
\hline $\begin{array}{l}\text { - } \quad \text { Sharing } \\
\text { experiences }\end{array}$ & + & + & + \\
\hline $\begin{array}{l}\text { Evaluation knowledge } \\
\text { and skills }\end{array}$ & & & \\
\hline $\begin{array}{l}\text { Planning, } \\
\text { structuring and } \\
\text { carrying out } \\
\text { evaluations }\end{array}$ & $\begin{array}{l}\text { +/- Planning } \\
+/ \text { - Structuring } \\
\text { + Carrying out }\end{array}$ & - & $\begin{array}{l}\text { + Planning } \\
\text { +/- Structuring } \\
\text { + Carrying out }\end{array}$ \\
\hline $\begin{array}{l}\text { Quality criteria } \\
\text { and activities for } \\
\text { evaluating } \\
\text { products }\end{array}$ & $+/-$ & - & $+/-$ \\
\hline $\begin{array}{l}\text { Analysing } \\
\text { outcomes and } \\
\text { improving } \\
\text { curriculum }\end{array}$ & + & - & + \\
\hline
\end{tabular}

In Thales and Othello all foreign language teachers were involved in the TDT, therefore managing and structuring the implementation process needed explicit attention. This explicit attention also seems to provide opportunities to enhance curriculum design expertise.

Each TDT also organised their own evaluation activities, which resulted in unplanned and unstructured evaluations in Plato and Othello. These evaluations provided the TDTs with insights in the practical quality of the curriculum: alignment with students' prior knowledge and internal consistency of the designed language. In Thales no evaluations were conducted, despite that they received external support about the role of evaluations and how to conduct them. The reason might be that the support on evaluation was not offered when the teachers needed it (cf. Handelzalts, 2009). 
Finally, teachers experienced that collegial feedback and presenting their TDT's progress to other TDTs made them aware of what they had achieved (cf. Hall \& Hord, 2010), but teachers did not indicate that that this fostered the implementation and evaluation process. Based on the evaluation activities carried out, it seems that teachers' expertise in this domain was limited (cf. Handelzalts, 2009; Kerr, 1981).

\subsubsection{Teachers' classroom implementation and evaluation activities}

The activities carried out in and by the TDT were intended to prepare the teachers to implement the new curriculum in the classroom and to evaluate the lessons. Classroom observations revealed great variation in classroom implementation between teachers within and between the different TDTs. The skill-oriented approach for learning languages required students to actively use the foreign language. The developed language tasks partly prescribed to what extent the foreign language had to be spoken by teachers and students, which was the case in Plato and Othello. The language village task, which was used in Othello, required both teachers and students to use the foreign language, since the conversations between them were the core of the task. Integrating the skillsoriented approach also required teachers to fulfil the role of coach. The results illustrated that the coaching differed between teachers both within and between cases. In Thales, the teachers offered a detailed introduction in which the whole language task was clarified to the students. In contrast, in Plato and Othello, teachers coached their learners by providing just-in-time guidance, which was required to complete the tasks.

Teachers' reflections revealed that classroom implementation and evaluation was affected by their understanding of CEFR and the new pedagogy and especially the teacher role. Plato's and Othello's teachers had various questions about their

role and wondered whether they offered too much guidance. Although within the TDTs various discussions had addressed the pedagogy and exemplary materials and videos were offered (cf. Ball \& Cohen, 1996), the results of this study suggests that only discussing and observing a new pedagogical approach is too limited to acquire the required expertise (cf. Voogt et al., 2011). Therefore, it seems that additional opportunities in which teachers can apply the new pedagogical approach and use the new curriculum are needed to be able to improve their pedagogical skills and develop confidence in the new approach. 
Teachers in all three TDTs discussed the language tasks with their fellowcolleagues during and outside TDT meetings. But collegial feedback appeared not enough to develop quality language tasks, emphasizing the need for piloting the language tasks in teaching practice (cf. Handelzalts, 2009). Furthermore, the results illustrated that teachers hardly involved students in their evaluations, suggesting that teachers need to learn how to involve their learners with the aim to improve the language tasks.

\subsubsection{Overall conclusion}

The results of this study illustrate that working in TDTs offer opportunities to practice and acquire implementation and evaluation skills (cf. Ben-Peretz, 1990; Voogt et al., 2011). Teachers' implementation expertise can be developed while collaboratively preparing classroom implementation and reflecting on the actual implementation. Moreover, teachers can learn to understand the importance of enhancing ownership while working in TDTs. Explicit attention for evaluation expertise is needed, since teachers hardly seem to develop this while working in TDTs (cf. Handelzalts, 2009; Hoogveld, 2003; Kerr, 1981).

\subsection{Discussion}

This study shed light on the implementation and evaluation activities carried out by teachers in TDTs and during classroom enactment of the new materials. First, the study shows that the members of the TDT need to understand the essence of ownership and how to foster it (cf. Kessels \& Plomp, 1999), especially when not all their colleagues are involved in the TDT. TDTs can achieve this by involving their colleagues at specific points during the design process, as was the case in Plato were colleagues outside the TDT were involved during support meetings.

Second, in contrary to Richey et al. (2001) managing the implementation process is not necessarily an expert-designer skill as this study found that TDT's coordinators had basic planning and monitoring skills.

Third, TDTs' activities that are closely related to (changing) classroom practice were valued by teachers and seem to offer opportunities for learning. Previous studies suggested that supporting teachers to reflect on their experiences help to 
deepen their understanding of the conducted activities (e.g., Anto, 2013; Huizinga et al., accepted).

Finally, classroom implementation helped to deepen teachers' understanding of the new curriculum, especially when they shared experiences with fellowteachers and had to explain what they did during classroom implementation (cf. Hall \& Hord, 2010).

Kirkpatrick (1979) argued that positive experiences and beliefs illustrate which activities are conditional for teacher learning. In this study, the conducted implementation and evaluation activities together with teachers' reflections on these activities were used to identify what opportunities TDTs provide for enhancing curriculum design expertise.

Therefore, the storyline method was applied to let teachers reflect on their process and the decisions made to conduct specific activities. It was assumed that when teachers did not conduct and did not indicate why certain activities were not conducted, they lacked the design expertise for implementation and evaluation. However, teachers might have the expertise, but did not reflect or demonstrate it during the process.

The knowledge and skills needed for implementation and evaluation were derived from overviews developed to describe the expertise of instructional and curriculum designers. Although in previous studies these knowledge and skills were translated to fit teachers and the design tasks they face (Huizinga, 2009; Huizinga et al., 2014; Nieveen \& Van der Hoeven, 2011), the results of this study suggests that some of the identified knowledge and skills for implementation and evaluation might not be developed through participation in TDTs. Teachers might not develop the expertise to plan and structure evaluations while working in TDTs and, therefore, need just-in-time support to acquire this expertise (cf. Handelzalts, 2009). This study also illustrated that support which is not offered just-in-time will not result in acquiring the expertise needed, as was the case in Thales.

The results of this study showed that without specific just-in-time support, TDTs initialise various activities to foster the implementation, such as enhancing ownership for the new curriculum (e.g., through involving colleagues in design activities) and sharing experience with teachers within and outside the TDT (e.g., by offering exemplary materials and videos). However, without support TDTs hardly plan and conduct (structured) evaluation to assess the quality of the designed 
curriculum (cf. Handelzalts, 2009; Kerr, 1981). The only evaluation activities by TDTs focused on the practical aspects of the curriculum (e.g., feasible within the given time, do the students understand and learn from the language task). They did not evaluate how the materials were used in the classroom or the effects of the materials on students. In some cases, students were involved in the evaluation activities. Since most evaluation activities were based on teachers' (personal) experiences to assess the quality, it seems that teachers in TDTs need additional expertise to conduct a wider variety of evaluation activities to assess the quality of the new curriculum. This additional expertise can be fostered by providing just-intime support aligned with teachers' prior knowledge and experiences. 


\title{
CHAPTER 5§ \\ Factors affecting teachers' ability to tackle design challenges
}

\begin{abstract}
During curriculum design processes, teachers as designers are faced with design challenges. Being able to deal with these design challenges is vital to conduct curriculum design. This study was set out to empirically verify personal, team and management factors affecting teachers' ability to tackle design challenges. A longitudinal quantitative study was conducted during a two-year project in which 15 Teacher Design Teams (TDTs) from different schools were involved. Data were collected through a questionnaire on the personal, team and management factors. A stepwise longitudinal multilevel analysis was conducted. The findings demonstrated that teachers' ability to tackle design challenges is affected by teachers' pedagogical content knowledge curriculum design expertise and prior experience in designing curriculum materials for collegial use in and outside the school.
\end{abstract}

\subsection{INTRODUCTION}

Teachers fulfilling the role of designer of curriculum materials is considered a promising approach for the implementation of curriculum reform at school level (Fullan, 2007; McLaughlin \& Talbert, 2006; Remillard, 1999, 2005; Stenhouse, 1975). It is assumed that their involvement as designers helps to develop ownership with the curriculum reform (Borko, 2004; Fullan, 2007). However, the design of curriculum materials is a complex process, which requires expertise that is often not part of teachers' repertoire. This expertise consists of the ability to conduct various activities, such as analysis, design, development, implementation and evaluation

$\S$ This chapter is based on the submitted article: Huiziga, T., Voogt, J. M., Handelzalts, A, Hubers, M. D., Nieveen, N., Pieters, J. M. (submitted). Factors affecting teachers' ability to tackle design challenges. 
(Gustafson \& Branch, 2002; Richey et al., 2001). Because teachers are not used to conducting design activities, they need to learn how to cope with design challenges.

Collaboration between teachers during the design process is recommended (e.g., Marsh et al., 1990; Nieveen, Van der Hoeven, Ten Voorde, Koopmans, \& Van Lanschot Hubrechts, 2013). Designing in teams of teachers may help to solve the problems teachers face in the design process, because they can share expertise, ideas and strategies throughout the process (Handelzalts, 2009; Hardré et al., 2006; Havnes, 2009; Penuel et al., 2007). In addition, teachers' active involvement in the design process and the collaboration in the team offers opportunities for learning (Desimone, 2009, 2011; Garet et al., 2001; Huizinga et al., 2013, accepted; Penuel et al., 2007; Voogt et al., 2011).

By working in teams, teachers as designers are expected to improve their ability to address the design challenges they encounter (e.g., Hardré et al., 2006; Huizinga et al., 2013, accepted). Design challenges consist of the decisions teachers have to make about the curriculum materials and the problems they face while creating these materials (e.g., Kerr, 1981; Handelzalts, 2009; Hardré et al., 2006).

Although teachers collaboratively designing in teams is a promising way to overcome the design challenges, the process of designing in teams is affected by various factors. Consequently, the development of effective teams is also affected. Discussing professional learning communities, Stoll et al. (2006) identified that, among other aspects, teachers' orientation to change, group dynamics, and school context are expected to influence the effectiveness of the design team. Vescio et al. (2008) found that collaboration in teams, the focus of the team, the authority of teachers and opportunities for continuous learning affect the effectiveness of teams. Although previous studies addressed the effectiveness of teacher communities and its effect on student learning (e.g., Bolam et al., 2005; Lee, Zhang, \& Yin, 2011; Lomos, Hofman, \& Bosker, 2011), no studies addressed how these factors influence teachers' ability to tackle design challenges. Furthermore, no studies were found in which the development of the ability to tackle design challenges was measured over time, when teachers are actually designing and face concrete design challenges. To empirically verify the factors that affect teachers' ability to tackle design challenges over time, the current study was conducted.

The factors identified in the studies of Stoll et al. (2006) and Vescio et al. (2008) on professional learning communities were also found in more recent qualitative studies in which teachers fulfilled the role of designer (e.g., Bakah et al., 2012; Beyer, 2009; 
Coenders, 2010; Handelzalts, 2009; Huizinga et al., 2013, 2014). Furthermore, the qualitative studies also suggested that personal and team factors affect teachers' ability to tackle design challenges. Figure 5.1 presents how teachers' ability to tackle design challenges is affected by personal, team and management factors. Personal factors reflect the individual expertise of the teachers as designer, team factors reflect the dynamics in the design team and the management factors addresses the role of the school's management in supporting a teacher team during the design process.

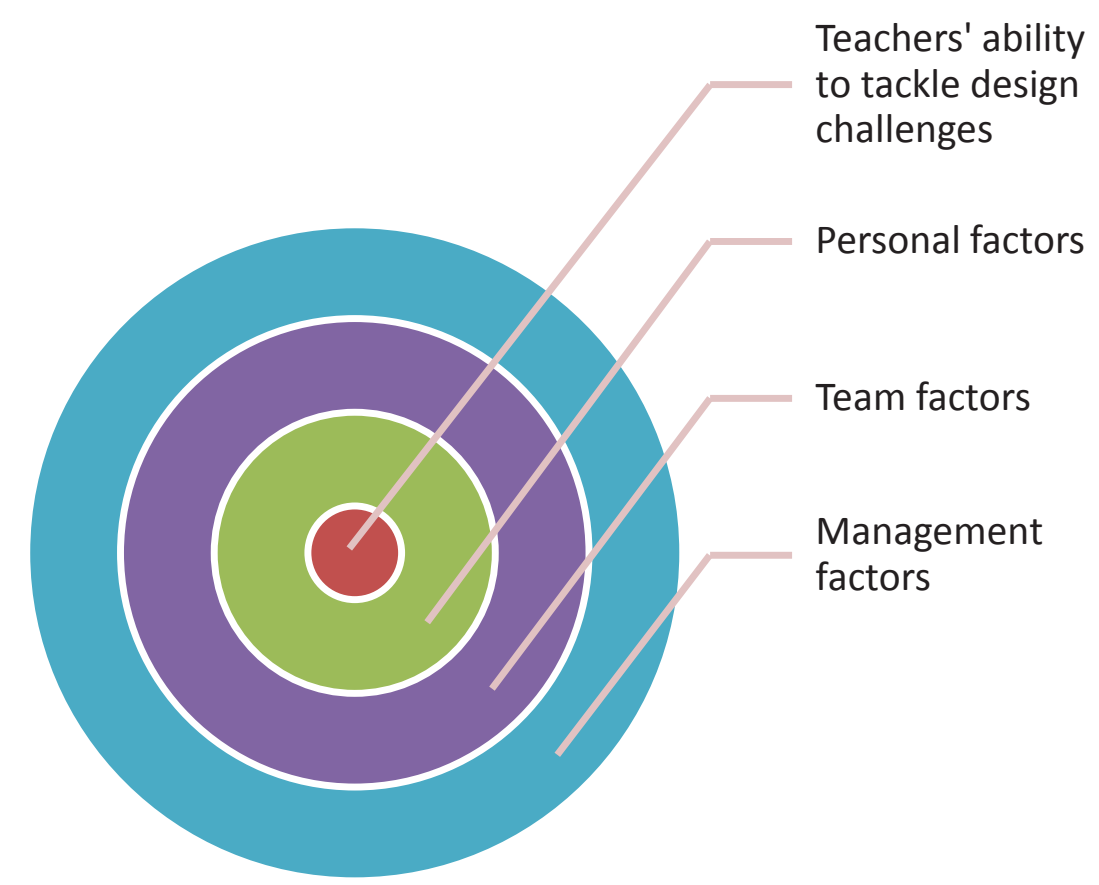

Figure 5.1 Graphical representation of the (personal, team and management) factors affecting teachers' ability to tackle design challenges

Personal factors and, in particular specific knowledge and skills, seem to affect how teachers tackle design challenges (Hardré et al., 2006; Nieveen et al., 2010). Various studies pointed out that, in general, prior experiences with designing curriculum materials affect how new challenges are solved (e.g., Norman, 1988; Koehler \& Mishra, 2005; Meirink, Imants, Meijer, \& Verloop, 2010). Teachers who have experience with curriculum design are expected to be better able to tackle the design challenges they face compared to teachers without any experience (Bakah et al., 2012; Eggleston, 1980). Teachers might have acquired this kind of experience while designing curriculum materials to be used in their own practice. Moreover, they might have experience with designing curriculum materials for fellow teachers in their own school, with teachers outside their school or they 
might have worked for an educational publisher (Marsh et al., 1990; Nieveen \& Van der Hoeven, 2011; Nieveen et al., 2013).

Teachers' Pedagogical Content Knowledge [PCK] refers to teachers' ability to transform subject matter knowledge in such a way that student learning is facilitated (Shulman, 1986). A teachers' PCK is also identified to affect the curriculum design process (Clarke \& Hollingsworth, 2002; Coenders, 2010; Schwab, 1973) and affects the quality of the materials that are being designed and its application in classroom practices (Beyer, 2009). Therefore, it is expected that teachers with a deep understanding of PCK can overcome design challenges easier than teachers with a limited understanding of PCK. As Hardré et al. (2006), Hardré (2009) and Huizinga et al. $(2013,2014)$ discussed that poor quality of curriculum materials can be the result of teachers' limited curriculum design expertise. Curriculum design expertise consists of the knowledge and skills needed to design quality curriculum materials (Huizinga, 2009; Huizinga et al., 2013). Teachers who are novices in curriculum design are expected to have more difficulties in finding and applying strategies or design models that can help them to overcome problems than teachers with more experience in curriculum design (e.g., Ertmer \& Cennamo, 1995; Hardré et al., 2006; Huizinga et al., 2013; 2014; Kerr, 1981). The assumption in this study is that prior experiences, PCK and curriculum design expertise positively affect teachers' ability to tackle design challenges.

Team factors are often reported to influence the design process, and, are also supposed to affect teachers' ability to overcome design problems (e.g., Handelzalts, 2009; Huizinga et al., 2013, 2014; Marsh et al., 1990). Lack of collaboration among teachers in teams was found to influence the design process (Hargreaves \& Dawe, 1990, Little, 1990, 2003). Teams that collaborate well are able to divide tasks, to foster professional commitment and to deal effectively with the interdependence among teachers as well (Akomaning, 2012; Alayyar, 2011; Handelzalts, 2009). In addition, teachers who appreciated the collaboration seemed to appreciate the overall design process and struggled less with the design process (Alayyar, 2011; Koehler et al., 2007). The assumption in this study is that when the collaboration within the team is experienced negative, teachers experience more difficulties in tackling design challenges.

Management factors seem to influence opportunities teachers have for conducting a successful design project. In the review studies of Stoll et al. (2006) and Vescio et al. (2008) it was shown that collaboration within teacher communities was affected by the support offered by the school management. Handelzalts (2009) 
found that support from the management influenced how teachers as designers conducted the design process. It is expected that when the management does not provide sufficient support (e.g., in terms of scheduled time, financial resources), teachers experience more difficulties during the design process and have more difficulties solving these problems (e.g., Davidson, Schofield, \& Stocks, 2001; Giles \& Hargreaves, 2006; Handelzalts, 2009; Hord, 2004; Kerr, 1981; Nieveen et al., 2010; Vescio et al., 2008). The assumption in this study is that the value teachers attach to support and the actual support they received affects teachers' ability to tackle design challenges.

As discussed above, previous qualitative studies have identified factors that affect teachers' ability to tackle design challenges. In addition, a few quantitative studies addressed the influence on teacher commitment to students (Lee et al., 2011) and the influence of professional communities on student achievement (Lomos et al., 2011). However, no studies were conducted that empirically verified factors that affect teachers' ability to tackle design challenges when teachers are designers of curriculum materials during a longer period of time. The current study was conducted to address these factors and was guided by the main research question: "Which factors (personal, team and management) affect teachers' ability to tackle design challenges over time?"

\subsection{Methods}

\subsubsection{Design of the study}

For answering the main research question a longitudinal multilevel approach was applied on data from a teacher questionnaire. The data collected had a nested structure and consisted of two-levels, namely the measurement moment (level 1) and the teachers (level 2). In total, data were collected three times during the project. Under these circumstances, applying a longitudinal multilevel approach is advocated (Hox, 2002; Snijders \& Bosker, 2012). An advantage of the longitudinal multilevel approach is that it adequately deals with missing data. 


\subsubsection{Research context}

The study was conducted during a two-year curriculum reform project in The Netherlands. Teams of foreign language teachers from different schools were faced with the implementation of the Common European Framework of References for languages (CEFR; Council of Europe, 2001). This reform required teachers to design new curriculum materials that align the skills-orientated approach recommended in the CEFR framework. The CEFR-project offered a prime opportunity to identify the factors that influence teachers' ability to tackle design challenges.

During the project, teams of foreign language teachers were responsible for the design and implementation of curriculum materials to accommodate the CEFR framework for their school. The teachers worked in school-based teams and developed a variety of new curriculum materials, including language tasks (authentic tasks in which students apply the language skills in a (simulated) context), assessment rubrics (to asses students' language skills) and vision documents (to describe the main school-specific adaptations of the reform). The teams can be considered as 'Teacher Design Teams' (cf. Handelzalts, 2009).

\subsubsection{Participants}

Foreign language teachers, from 15 schools, involved in a two-year national project participated in this study. They agreed on the integration of the curriculum reform in classroom practice and in the design of curriculum materials. In some schools, all foreign language teachers designed the curriculum materials from the early stages of the design process. In other cases a small design team started designing and later on involved their colleagues in the design process.

The foreign language teachers offer the subjects English, French, German or Spanish to 11 - 18 years old students in secondary education in the Netherlands. From the 200 foreign language teachers to whom the questionnaire (see instrumentation) was sent, 124 foreign language teachers completed the questionnaire. From the 124 foreign language teachers $73 \%$ was female, which is common in the Netherlands (Stamos, 2014). On average these 124 foreign language teachers had 14.5 years of teaching experience. Further characteristics are provided in Table 5.1. During the two-year project, three schools and its teachers discontinued the project as well as few teachers from other schools (because they left the school), which resulted in non-response and missing data. 
Table 5.1 Overview of the participants per administration of the questionnaire

\begin{tabular}{|c|c|c|c|}
\hline & $\begin{array}{l}\text { Start of the project } \\
(N=74)\end{array}$ & $\begin{array}{l}\text { After one year } \\
(N=44)\end{array}$ & $\begin{array}{l}\text { End of the project } \\
(N=57)\end{array}$ \\
\hline \multicolumn{4}{|l|}{ Gender } \\
\hline Male & 22 & 11 & 14 \\
\hline Female & 51 & 33 & 43 \\
\hline $\begin{array}{l}\text { Teaching experience in } \\
\text { years Mean }(S D)\end{array}$ & $12.70(10.65)$ & $17.19(12.19)$ & $14.82(11.84)$ \\
\hline \multicolumn{4}{|l|}{ Subject domain } \\
\hline English & 26 & 22 & 25 \\
\hline French & 22 & 7 & 11 \\
\hline German & 25 & 13 & 20 \\
\hline Spanish & 1 & 2 & 1 \\
\hline
\end{tabular}

\subsubsection{Instrumentation}

For identifying the factors that affect teachers' ability to tackle design challenges, a questionnaire was developed. During its development the items and scales were discussed in the research team to determine content validity (DeVellis, 2003). The developed self-report instruments adapted existing scales to measure the personal (Hardré et al., 2006; Huizinga, 2009; Schmidt et al., 2009) and team factors (Akomaning, 2012; Alayyar, 2011), whereas the scales measuring the management factors, were developed by the researcher. In total 39 items were included in the questionnaire (see Appendix $\mathrm{P}$ for the complete questionnaire). Before the questionnaire was actually administered, teachers who were not part of the sample filled in the questionnaire and provided feedback on the items. The operationalization of the variables in the questionnaire is discussed in detail in the next section.

\section{Ability to tackle design challenges}

The dependent variable is 'tackling design challenges' and is adapted from the instrument of Hardré et al. (2006). The scale reflects teachers' (self-reported) ability to find and apply strategies to overcome problems during the design process. All items were measured using a five-point Likert-scale ranging from totally disagree (1) to totally agree (5). Cronbach's a for this scale was high: $\mathrm{a}=.80$. The scale consisted of 6 items, example items are: "I believe that I can manage most design challenges during the design of curriculum materials" and "I would be able to find an appropriate strategy to tackle design challenges". 


\section{Background variables}

Background information of the participants was gathered as part of the questionnaire. The background variables that might affect the dependent variable include school, gender, subject domain (foreign language), and teachers' teaching experience in years.

\section{Personal factors}

Teachers' prior experiences in curriculum design were measured using five items. Each item used a yes/no scale. The items were

- "I have designed for own purpose"

- "I have designed for collegial purpose within the school"

- "I have designed for collegial purpose outside the school"

- "I have designed for an educational publisher"

- "I have provided feedback on the curriculum materials designed by an educational publisher"

These prior experiences in curriculum design were included, because it was expected that teachers might have been involved in curriculum design processes before.

In addition, two scales were used to measure the personal factors, namely curriculum design expertise and pedagogical content knowledge. Items in both scales were measured using a five-point Likert-scale ranging from totally disagree (1) to totally agree (5). Pedagogical content knowledge [PCK] was covered by 12 items adapted from Schmidt et al. (2009). Exemplary items are "I can select appropriate learning activities for my lessons" and "I can apply various learning activities in my lessons". Curriculum design expertise consisted of six items derived from Huizinga (2009). Exemplary items are "During the design I would systematically evaluate (parts of) the curriculum materials to improve the practical usability" and "I would collaboratively generate ideas with colleagues about how to make improvements". Cronbach's a for PCK was high: $a=.89$ and Cronbach's a for curriculum design expertise [CDE] was good: $a=.75$.

\section{Team factors}

The team factor was measured by one scale addressing collaboration in the team. The scale consisted of seven items, which were adapted from Akomaning (2012) and Alayyar (2011). The items in the scale were measured using a five-point Likert-scale ranging from totally disagree (1) to totally agree (5). Exemplary items are "We have collaboratively made decisions about the content of the curriculum 
materials" and "I find that our design team collaborate effectively". Cronbach's a for this scale was high: $\alpha=.86$.

\section{Management support factors}

For measuring the management support factors new scales were developed. A principal components factor analysis with varimax rotation and Kaiser normalization was used to explore the scales for management support factors. Based on the Kaiser Guttman rule, which indicates that factors with eigenvalues greater than 1 should be accepted, the number of factors were derived. During the refinement of the emerged scales, only items, which had a factor loading of .50 or above, were retained. Two scales measured the management support factors, namely the importance of management support and the received management support. The items in both scales were measured using a five-point Likert scale ranging from totally disagree (1) to totally agree (5). The importance of support consisted of five items. Example items are "I find it important that our management provides us with (financial) resources for the development of our foreign language curriculum" and "I find it important that our management sometimes joins design meetings" Cronbach's a for this scale was good: $a=.75$. The received management support consisted of three items. Example items for this scale are "Our management showed interest in the progress of our project" and "Our management showed interest in the decisions made about our foreign language curriculum". Cronbach's a for this scale was high: $\alpha=.83$.

\subsubsection{Data analysis}

Teachers (level 2 of the analysis) filled in the questionnaire three times (level 1, measurement moment). In order to take this hierarchical structure of the data into account, a longitudinal linear multilevel analysis was performed. A stepwise approach was applied to construct the model by systematically adding the personal, team and management factors to the model. The development of the model began by testing whether a multilevel approach provided a better fit for the data than linear regression. This was determined by developing the nullmodel. Throughout the development a pre-determined approach was used, namely by adding new variables and removing non-significant scales from the model before new variables were added.

The stepwise approach was as follows, each resulting in a new model. First, the null-model was built. Second, background variables were added to the model 
(e.g., gender, teaching experience). Third, the personal factors were added. Fourth, team factors ware included to the model. Fifth, management factors were added to the model. After determining which factors influenced teachers' ability to tackle design challenges, interaction effects, quadratic growth and random slopes were included in the model, again by using a stepwise approach.

\subsection{RESUlts}

\subsubsection{Descriptive statistics and correlations}

Table 5.2 presents the descriptive statistics for each scale and correlations between the scales per administration. As Table 5.2 shows, teachers' PCK, CDE and ability to tackle design challenges increase per administration. Furthermore, PCK and CDE both significantly correlate with tackling design challenges.

Teachers' prior experiences in curriculum design per administration are provided in Table 5.3. The table shows that most teachers had experience in the design of curriculum materials that are used in their own classroom practice. Only few teachers had experience as designers of curriculum materials for an educational publisher.

Table 5.2 Descriptive statistics and correlation between the scales per administration

\begin{tabular}{|c|c|c|c|c|c|c|}
\hline $\begin{array}{l}\text { First administration } \\
(N=74)\end{array}$ & 1 & 2 & 3 & 4 & 5 & 6 \\
\hline 1. PCK & - & & & & & \\
\hline 2. $\mathrm{CDE}$ & .05 & - & & & & \\
\hline 3. Collaboration & .11 & $.49 * *$ & - & & & \\
\hline 4. Importance of support & .20 & $.30^{*}$ & $.30^{*}$ & - & & \\
\hline 5. Received support & -.04 & $.27^{*}$ & $.47^{* *}$ & .22 & - & \\
\hline $\begin{array}{l}\text { 6. Tackling design } \\
\text { challenges }\end{array}$ & $.44^{* *}$ & $.31^{*}$ & $.34^{* *}$ & $.27^{*}$ & .12 & - \\
\hline Mean & 3.91 & 3.55 & 3.55 & 4.17 & 3.56 & 3.57 \\
\hline$S D$ & .36 & .60 & .56 & .40 & .70 & .52 \\
\hline
\end{tabular}


Table 5.2 Descriptive statistics and correlation between the scales per administration (continued)

\begin{tabular}{|c|c|c|c|c|c|c|}
\hline $\begin{array}{l}\text { Second administration } \\
(N=44)\end{array}$ & 1 & 2 & 3 & 4 & 5 & 6 \\
\hline 1. PCK & - & & & & & \\
\hline 2. $\mathrm{CDE}$ & .29 & - & & & & \\
\hline 3. Collaboration & .19 & .19 & - & & & \\
\hline 4. Importance of support & .14 & -.15 & .20 & - & & \\
\hline 5. Received support & -.10 & -.10 & -.31 & -.37 & - & \\
\hline $\begin{array}{l}\text { 6. Tackling Design } \\
\text { challenges }\end{array}$ & $.46^{* *}$ & $.34^{*}$ & .19 & -.15 & -.10 & - \\
\hline Mean & 3.96 & 3.65 & 3.24 & 4.03 & 2.92 & 3.70 \\
\hline$S D$ & .31 & .39 & .67 & .42 & .79 & .42 \\
\hline $\begin{array}{l}\text { Third administration } \\
(N=57)\end{array}$ & 1 & 2 & 3 & 4 & 5 & 6 \\
\hline 1. PCK & - & & & & & \\
\hline 2. $\mathrm{CDE}$ & .18 & - & & & & \\
\hline 3. Collaboration & .26 & $.41^{*}$ & - & & & \\
\hline 4. Importance of support & .09 & .28 & .16 & - & & \\
\hline 5. Received support & $-.46 * *$ & .06 & .03 & -.14 & - & \\
\hline $\begin{array}{l}\text { 6. Tackling design } \\
\text { challenges }\end{array}$ & $.46 * *$ & $.35 *$ & $.40 * *$ & .28 & .06 & - \\
\hline Mean & 4.03 & 3.66 & 3.40 & 2.83 & 4.02 & 3.70 \\
\hline$S D$ & .44 & .48 & .67 & .93 & .48 & .43 \\
\hline
\end{tabular}

Note: $\quad{ }^{*} \mathrm{p}<0.05 ;{ }^{* *} \mathrm{p}<0.01$

Table 5.3 Teachers' prior experiences in curriculum design per administration

\begin{tabular}{|c|c|c|c|}
\hline & $\begin{array}{l}\text { Start of the project } \\
(N=74)\end{array}$ & $\begin{array}{l}\text { After one year } \\
(N=44)\end{array}$ & $\begin{array}{l}\text { End of the project } \\
(N=57)\end{array}$ \\
\hline 1. Designed for own purpose & 62 & 40 & 51 \\
\hline $\begin{array}{l}\text { 2. Designed for collegial purpose } \\
\text { within the school }\end{array}$ & 53 & 35 & 41 \\
\hline $\begin{array}{l}\text { 3. Designed for collegial purpose } \\
\text { outside the school }\end{array}$ & 14 & 6 & 8 \\
\hline $\begin{array}{l}\text { 4. Designed for an educational } \\
\text { publisher }\end{array}$ & 5 & 1 & 7 \\
\hline $\begin{array}{l}\text { 5. Provided feedback on designed } \\
\text { materials by an educational } \\
\text { publisher }\end{array}$ & 8 & 6 & 10 \\
\hline
\end{tabular}




\subsubsection{The null model}

First, an empty random intercept model was specified. This null model was used to determine whether a multilevel structure provided a better fit for the data than a single level structure. The fixed intercept of the model refers to the overall mean score $(M=3.65)$ for 'ability to tackle design challenges'. The variance of the fixed intercept was .14. The null-model indicated that a multilevel structure provided a better fit for the data than the single level structure, since the $\chi^{2}$ test of the fixed intercept model only and the null model differed significantly $\left(\chi^{2}=\right.$ 46.54, $d f=1 ; \mathrm{p}<0.001)$. Therefore, the stepwise approach to develop the model was applied (see Table 5.4).

\subsubsection{Model 1}

The second step was to include the background variables of the participants in the model (Table 5.4). Teaching experience in years, gender, school and the foreign language course they teach were included. Although the model provided a better fit for the data $\left(\chi^{2}=21.81, d f=5 ; p<0.001\right)$, the individual estimates of the variables were not significant. The estimate for time (representing the measurement moment) was significant in model 1a. All non-significant variables were removed from the model, which resulted in model $1 \mathrm{~b}$.

\subsubsection{Model 2}

In the next step, the personal factors were added to model $1 \mathrm{~b}$ (Table 5.4). Teachers' PCK, CDE and teachers' prior experience with design were added. The model provided a significant better fit for the data $\left(\chi^{2}=57.94, d f=7 ; p<0.001\right)$, which suggested that teachers with a higher score for the personal factors are more likely to report a higher perceived ability to tackle design challenges. The non-significant variables were removed from the model. Model $2 \mathrm{~b}$ indicated that teachers with prior experience in curriculum design were more likely to feel capable to tackle design challenges, but only when this experience addressed the design of curriculum materials for colleagues within or outside their schools. Moreover, teachers' PCK and CDE significantly affected teachers' ability to overcome design challenges. Finally, the estimate for the time variable remained significant, indicating that over time, teachers were more likely to feel capable in tackling design challenges. 


\subsubsection{Model 3}

The fourth step was to include the team factor 'collaboration' to the model. The model provided a better fit for the data than model $2 b\left(x^{2}=10.21, d f=1 ; p<0.01\right)$. However, the estimated effect of collaboration was not significant, suggesting that collaboration within the design team might not influence teachers' ability to tackle the design challenges. Therefore, model $2 b$ provided a better fit for the data.

\subsubsection{Model 4}

In the fifth step, the management factors were included (Table 5.4). The model provided a better fit for the data than model $2 b\left(\chi^{2}=9.26, d f=2 ; p<0.01\right)$. However, the estimated effect of both variables was not significant, implying that both management scales did not affect teachers' perceived ability to tackle design challenges. Therefore, model $2 \mathrm{~b}$ provided a better fit with the data.

\subsubsection{Model 5}

Next, the possibility of interaction effect and quadratic growth were tested. Model $2 b$ was used for this, since it provided the best fit for the data, the interaction between teachers' PCK and CDE was added to the model. Furthermore, it was investigated whether quadratic growth provided a better fit with the data than linear growth. The model did not provided a better fit for the data $\left(\chi^{2}=9.26, d f=\right.$ 2; ns). Furthermore, the estimated interaction and quadratic growth effects were not significant. Therefore, both were removed from the model and still model $2 b$ provided a better fit for the data.

\subsubsection{Model 6}

The final step in the development of the model was to include random slopes. For determining the random slopes, model $2 \mathrm{~b}$ was used as a starting point. First, model 6a was developed by including the random slope for the time variable. Although the model better fitted the data $\left(\chi^{2}=5.05, d f=1 ; p<0.05\right)$, the estimated effect for the random slope was not significant. Therefore, the random effect was removed. Second, model $6 \mathrm{~b}$ was built by including the random slope for PCK. The model did not provide a better fit for the data than model $2 \mathrm{~b}\left(\chi^{2}=0.71, d f=1 ; n s\right)$ and the estimated effect was not significant. Finally, model $6 c$ was built by including the random slope for $\mathrm{CDE}$. The model provided a better fit for the data $\left(\chi^{2}=10.20, d f=\right.$ $1 ; p<0.01)$. However, the estimated effect for the random slope was not significant. Therefore, the random effect for CDE was removed from the model. 
Table 5.4 Estimates and standard errors from the random intercept model (dependent variable: tackling design challenges)

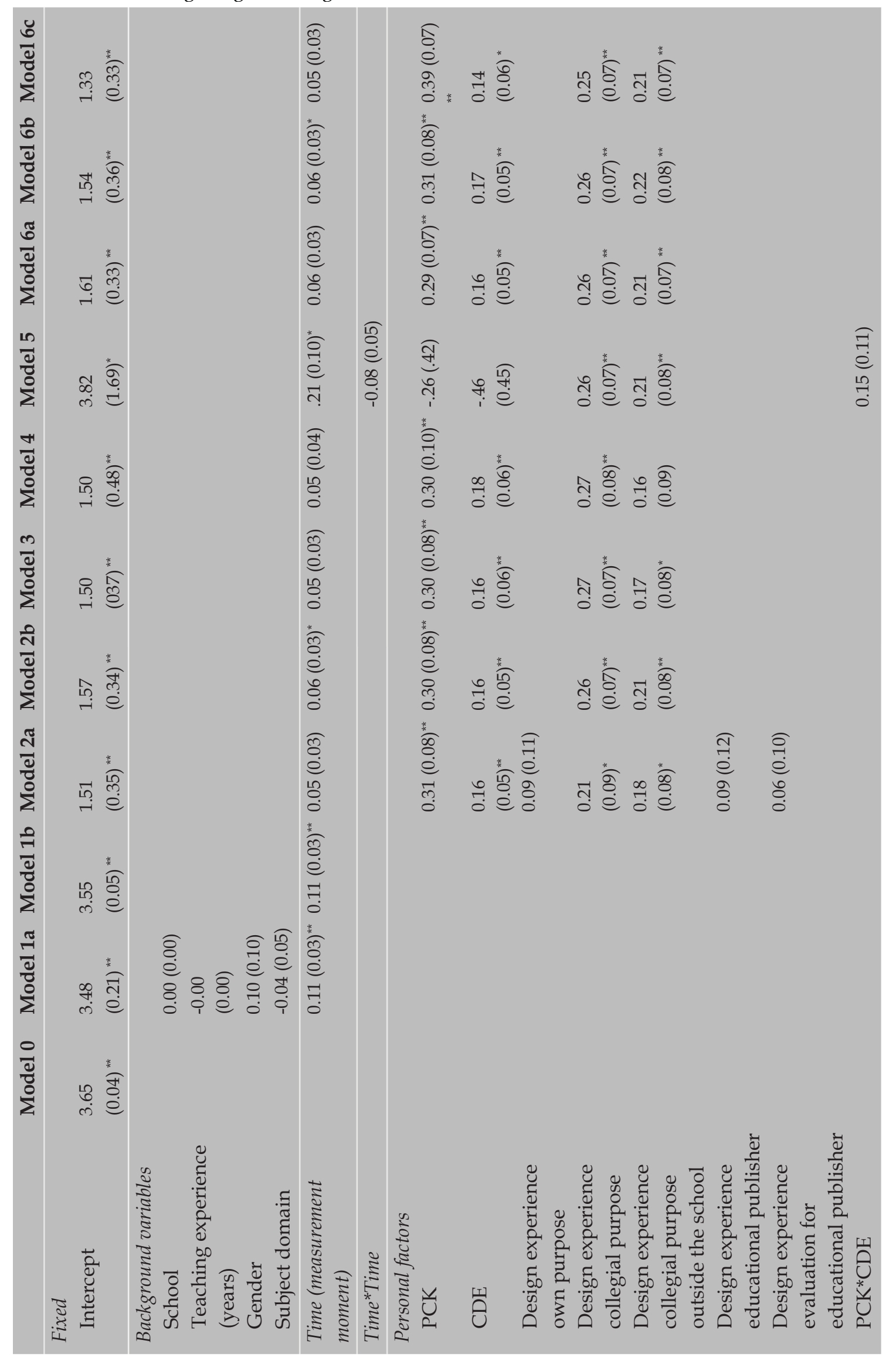


Table 5.4 Estimates and standard errors from the random intercept model (dependent variable: tackling design challenges) (Continued)

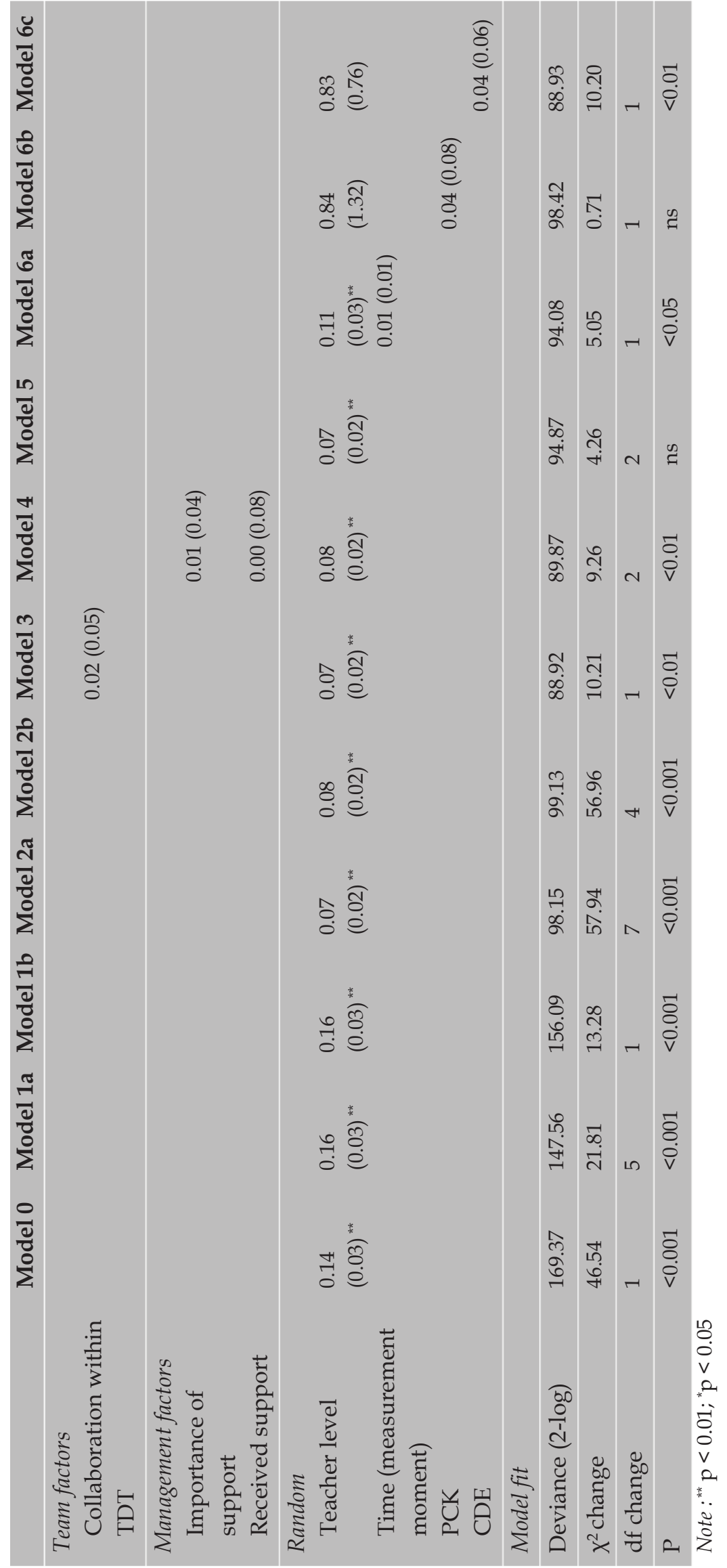




\subsubsection{Final model}

The model that provided the best fit for the data was model $2 \mathrm{~b}$. This model suggested that the ability to tackle design challenges was positively affected by teachers' PCK and CDE. Additionally, teachers with prior experience in the design of curriculum materials, namely developing curriculum materials which were to be used by colleagues within and outside the school, were more likely to feel more capable to tackle design challenges. Furthermore, the model showed that teachers' ability to tackle design challenges was positively affected by time, in that over time, teachers were more likely to report a higher ability to tackle design challenges.

For the final model, the calculation of the squared multiple correlation coefficient $\left(\mathrm{R}^{2}\right)$ offers the proportion of explained variance (Snijders \& Bosker, 2012). $R_{1}^{2}$ at the teacher level is defined as the proportional reduction of errors for predicting an individual outcome. $R_{1}^{2}$ was calculated using the formula $\mathrm{R}^{2}=1-($ Variance model 2b / Variance null model). The total variance of the null model was $(.06+.14)=.20$. The total variance of model $2 \mathrm{~b}$ was $(.05+.08)=.13$. Therefore, $R_{1}^{2}$ was $1-(.13 / .20)=.35$. Compared to the null model, the proportion of explained variance in the final models is $35 \%$. Time, PCK, CDE and prior experience with design for collegial purpose within the school and prior experience with design for collegial purpose outside the school accounted for this variance at the teacher level.

\subsection{CONCLUSION AND DISCUSSION}

This study was set out to empirically verify factors that affect teachers' ability to tackle design challenges. Three assumptions were verified in this study. Furthermore, it was expected that time had a positive effect on teachers' ability to tackle design challenges.

The first assumption was that prior experiences, PCK and curriculum design expertise positively affect teachers' ability to tackle design challenges. The findings of this study underlined that teachers' PCK, CDE and prior experience with the design of curriculum materials for collegial purpose inside and outside the school positively affected teachers' ability to tackle design challenges. Although it was expected that teachers' prior experience of designing curriculum materials for own purpose and for educational publishers could also affect teachers' ability to tackle design challenges, the findings of this study did not support this assumption. 
The second assumption was that when the collaboration within the team is experienced negative, teachers report more difficulties in tackling design challenges. The findings of this study do not support this assumption. During the development of the model, the estimated effect for collaboration was not significant, suggesting that collaboration in the team did not affect teachers' ability to tackle design challenges.

The third assumption was that the value teachers attach to support in general and the actual support they received affects teachers' ability to tackle design challenges. The findings of this study did not support this assumption. This implies that teachers' opinion about the importance of support and the received support do not affect teachers' ability to tackle design challenges.

The final model suggested that time had a positive effect and that a linear growth model had the best fit with the data. Compared to the null model, the final model explained the individual outcomes 35\% better than the null model, suggesting a medium effect of time, PCK, CDE and teachers' prior experience in designing curriculum materials for collegial purpose within and outside the school.

The findings of this study show that, over time, teachers as designers are likely to feel more capable to cope with design challenges. This is probably because the teachers in this study were actually designing for their own context and faced and tackled concrete design challenges during the design process by making sitespecific decisions regarding the design of curriculum materials (cf. Hardré et al., 2006; Huizinga et al., 2013, 2014). Teachers might have learned from being involved in collaborative design, which prior studies also suggested (Handelzalts, 2009; Huizinga et al., 2014; Velthuis, 2014; Voogt et al., 2011). They possibly found familiar challenges in the design process and knew how to deal with these challenges (cf. Norman, 1988; Koehler \& Mishra, 2005; Meirink et al., 2010). The findings of this study also underline the importance of teachers' PCK and CDE. This confirms findings from other studies that teachers with sufficient PCK and CDE can better cope with design challenges (Beyer, 2009; Coenders, 2010; Hardré et al., 2006; Huizinga et al., 2014).

Although team factors are often identified to influence the design process (e.g., Handelzalts, 2009; Huizinga et al., 2013, 2014; Voogt et al., 2011), the results of this study do not support this. A possible explanation is that the design teams 
consisted of teachers from the same school, implying that they might have collaborated in previous projects and, therefore, might have had a realistic understanding of the collaboration. Another result that did not support findings from other studies was the influence of the support from the management (e.g., Davidson et al., 2001; Handelzalts, 2009; Hord, 2004; Giles \& Hargreaves, 2006). Teachers' opinion on the importance of support and actual support received did not seem to have an effect on teachers' ability to tackle design challenges. Although management support seems an essential condition for conducting design processes (Handelzalts, 2009; Skilbeck, 1984), it did not influence how capable teachers feel in dealings with design challenges. This might be because such management support does not help to overcome the design challenges, but only provides opportunities to collaborate.

The current study was carried out in a real two-year project in which 15 teams of teachers were faced with the design and implementation of curriculum reform in their classroom practices. Conducting longitudinal studies in realistic contexts is difficult because participation rates of schools and teachers may change during the period of the study. This also explains the variation in response rate between the administrations of the questionnaire. Additionally, due to self-selection, teachers who completed the questionnaire(s) might be biased about the design process and their experiences. However, based on the background variables, it can be concluded that the samples for each administration are comparable. For example, the division between male and female teachers stayed the same during each administration. And although teaching experience was (slightly) higher in the second administration, the years of teaching experience suggests that teachers were in the same stage of their professional career (Huberman, 1993).

The findings of this study are a first step in the empirical verification of factors affecting teachers' ability to tackle design challenges. To further develop the model, additional perspectives should be included. A next step is to address to what extent teacher learning takes place during collaborative design and affects teachers' ability to tackle design challenges. It is advocated to address to what extent teachers experience learning in the team and how they share expertise. For management factors additional scales can be included addressing how management facilitates teacher design in teams and whether they offer opportunities to deal with design challenges. 
In conclusion, the findings of this study are a first step in quantitatively verifying factors affecting teachers' ability to tackle design challenges by utilizing a longitudinal quantitative approach. The findings revealed the importance of teachers' PCK, CDE and prior experience in the design of curriculum materials for collegial purposes in and outside the school to cope with design challenges. Based on these new insights, it is advocated to more often conduct similar longitudinal studies during curriculum design processes. Although conducting this type of studies in a realistic context is difficult, it is essential to improve our understanding of teachers as designers, and the factors that influence their ability to overcome design problems. From a practical point of view, the findings of this study demonstrated the importance of teachers' PCK, their curriculum design expertise and their prior experiences in curriculum design while engaging in new curriculum design projects. 


\section{CHAPTER 6 Summary and Discussion}

This chapter summarises the findings from the four sub-studies presented in this dissertation. First, an overview of the study is presented. Then, the research outcomes are summarised per sub-study. Next, the overall conclusion is provided, which is followed by a reflection on the research methodology and a reflection on the outcomes of the study. The chapter ends with recommendations for practice and research.

\subsection{OVERVIEW OF THE STUDY}

The study presented in this thesis was focused on the design and implementation of a curriculum reform and the role of the key player in this complex process: the teacher. It was argued that, despite the best intentions and ambitions of the various stakeholders, curriculum reforms too often are only partially implemented or fall short of realizing the educational goals (Fullan, 2007; Green, 1980; Stenhouse, 1975; Van den Akker, 2010). The thesis started with an account regarding the often reported failure of this complex process. The lack of involvement of teachers and their lack of ownership with the reform were identified as important reasons for the failure of many curriculum reforms (e.g., Borko, 2004). To foster the design and especially the implementation of curriculum reform, various scholars advocated the need for teacher involvement, starting teachers from the early stages of curriculum reform processes (e.g., Fullan, 2007; Stenhouse, 1975). By fulfilling the role of designer, it is expected that teachers' understanding of the reform and their ownership concerning the reform are being promoted. However, in those instances where teachers did fulfil the role of designer of curriculum materials, it was found that they lacked the knowledge and skills needed for proper curriculum design (e.g., Bakah et al., 2012; Handelzalts, 2009). The assumption underlying this study was that teachers need to develop their curriculum design expertise to be able to cope with the problems encountered in design processes and to create quality 
curriculum materials. This may eventually lead to successfully design and implement the intended curriculum reform. Furthermore, it was argued that teachers need to have generic design and process expertise and specific design expertise. Generic design and process expertise is needed to foster collaboration in the team and to manage the design process. The specific design expertise addresses teachers' subject matter knowledge, pedagogical content knowledge and curriculum design expertise needed for the design of curriculum materials.

The conceptual framework pertained to the desired curriculum design expertise of teachers and the development of that expertise in order to become competent designers. Although many teachers have intuitive design expertise, they also experience knowledge and skills-related problems while conducting curriculum design processes (e.g., Bakah et al., 2012; Forbes, 2009; Handelzalts, 2009; Nieveen et al., 2010). Therefore, it was assumed to be essential that teachers receive support in order to assist in developing their specific design expertise and especially their curriculum design expertise (Hardré et al., 2006; Nieveen et al., 2005). Little is known what opportunities Teacher Design Teams [TDTs] offer to teachers for developing their curriculum design expertise while being involved in a TDT (Hardré et al., 2006; Nieveen et al., 2010). This observation led to the main question that guided the study:

What opportunities do TDTs provide for teachers to develop curriculum design expertise?

This research question was operationalised in four sub-questions and these were empirically dealt with in the subsequent sub-studies in this thesis:

1. What are TDTs' needs for support during collaborative design of lesson series?

2. What design and support activities in TDTs do foster the development of teachers' curriculum design expertise?

3. What implementation and evaluation activities during the design of a new curriculum do provide opportunities for enhancing teachers' curriculum design expertise?

4. Which factors (personal, team and management) affect teachers' ability to tackle design challenges over time?

The four sub-studies were set out to more specifically determine the kind of design expertise teachers need and to identify the opportunities TDTs offer to develop teachers' curriculum design expertise. 
The study took place in teams of teachers for secondary education who faced the implementation of the Common European Framework of Reference for languages (CEFR). During a two-year project 15 teams of foreign language teachers collaboratively designed CEFR-attuned curriculum materials and implemented these in their classrooms. The curriculum materials they developed included language tasks, assessment rubrics and vision documents. During this project, each TDT received support from curriculum developers from SLO, the National Institute for Curriculum Development. Support was adjusted to their articulated needs and the design challenges coped with.

\subsection{SUMMARY OF THE FINDINGS}

\subsubsection{First study - Need for support to enhance teachers' curriculum design expertise}

The first study (chapter 2) was set out to answer the research question: 'What are TDTs' needs for support during collaborative design of lesson series?' The support that teachers need and/or receive provides insights in the curriculum design expertise that teachers need to require in the process of designing quality curriculum materials. In the first study, the concepts curriculum design expertise and characteristics of support were elaborated. Moreover, six teachers who were involved in TDTs and six facilitators who offered support to TDTs reflected on their specific design processes, the problems they experienced and on the support that was offered. Data were collected through semi-structured interviews with the respondents.

Based on the findings of this study it was concluded that teachers need support to enhance their curriculum design expertise and to (partly) develop their pedagogical content knowledge [PCK]. Further, teachers require just-in-time support from the early stages of the design process. This support needs to include offering templates, curricular frameworks and evaluation guidelines to address the questions teachers have regarding designing quality curriculum materials. 


\subsubsection{Second study - Fostering teachers' curriculum design expertise in Teacher Design Teams}

The second study (chapter 3) was guided by the research question 'What design and support activities in TDTs do foster the development of teachers' curriculum design expertise?' The study focused on the analysis, design and development activities conducted during the first year of the two-year curriculum design project in the context of a renewal in foreign language education in secondary education. The two participating TDTs of two different schools received support from an external facilitator. The design and support processes of the TDTs were analysed using a case study approach. The study included observation data, interview data and data from storyline reflections.

It was concluded that to develop curriculum design expertise that support to TDTs need to be aligned with the aim of the TDTs' design process and must be coherent with international standards and teachers' prior expertise in curriculum design. Moreover, balancing proactive and reactive support seems essential. Finally, TDTs need to include (1) support activities that are directly applicable for the specific design activities the TDTs are carrying out, such as exemplary materials and design templates; (2) activities that help teachers in conducting evaluations (e.g., screening and providing collegial feedback) from the early stages of the design process and using the evaluation outcomes to improve the curriculum materials; and (3) activities during which teachers as designers share their experiences with the design process, the decisions made and the resulting curriculum materials with teachers outside the TDT.

\subsubsection{Third study - Implementation and evaluation activities in design teams}

To answer the third sub-question 'What implementation and evaluation activities during the design of a new curriculum do provide opportunities for enhancing teachers' curriculum design expertise?', the implementation and evaluation activities of TDTs and the support offered to TDTs were examined (chapter 4). The specific knowledge and skills needed to conduct implementation and evaluation activities were identified and operationalised. The study was conducted during the second year of the two-year curriculum design project in the context of a renewal in foreign language education in secondary education. Data on the implementation and evaluation activities of three TDTs from different schools and its members were gathered using a case study approach. The study included observational data, interview data and data from the storyline reflections based on teachers' 
involvement in the TDT and their experiences with using the designed curriculum materials in their own classrooms.

In this study, teachers conducted various implementation activities and only few evaluation activities. For the teachers in the TDTs it became also much clearer how important it is to enhance their colleagues' ownership for the materials. They achieved this by can collaboratively preparing classroom implementation, and by sharing experiences of classroom implementation with colleagues outside the TDT by offering exemplary materials and video-recordings of lessons. The observations revealed that TDTs conducted few evaluation activities. The evaluations they did perform were rather unprepared, unstructured and emphasised the practical quality of the new curriculum materials, and less on the students' learning gains. This led to the conclusion that teachers in TDTs need additional support to conduct evaluation activities.

\subsubsection{Fourth study - Factors affecting teachers' ability to tackle design challenges}

The fourth study (chapter 5) aimed to empirically verify personal, team and management factors affecting teachers' ability to tackle design challenges over time. The personal, team and management factors included in the study were derived from qualitative studies in which teachers fulfilled the role of designer. The personal factors included teachers' prior experience in curriculum design, PCK and curriculum design expertise [CDE]. The team factor concerned collaboration within the team. The management factors referred to the support the management offered to design teams. Here, two factors were distinguished, the importance of support and the actual support received. Scales were developed to measure teachers' $\mathrm{PCK}, \mathrm{CDE}$, collaboration in the team and importance of management support and the actual support received from the management. Teacher data, from teachers of all 15 participating TDTs in the two-year CEFRproject, were collected at the start of the project, after one year and at the end of the CEFR-project (after two years). A longitudinal multilevel analysis was applied and a stepwise approach was used for building the longitudinal multilevel model.

Based on the findings of this study it was concluded that teachers' ability to tackle design challenges is affected by teachers' personal factors, in particular teachers' prior experience with curriculum design for collegial purposes (within and outside) the school, PCK and curriculum design expertise. In this study, contrary to findings from the qualitative studies, team and management factors did not 
affect teachers' ability to tackle design challenges. By involving teachers in the design process, they experiences what it takes to conduct curriculum design activities for their own context: they encounter design challenges and need to make site-specific decisions regarding the design of curriculum materials they will use in their own particular context. All of these curriculum design expertise seem to provide opportunities for developing teachers' understanding of how to cope with design challenges.

\subsection{CONCLUSION}

The study in this thesis was set out to answer the research question: 'What opportunities do TDTs provide for teachers to develop curriculum design expertise?' Four sub-studies were executed in order to identify those aspects that affect the development of teachers' curriculum design expertise in TDTs. Based on the findings of these studies, the following overall conclusions can be drawn.

Teachers as designers have to deal with design challenges when they design curriculum materials in teams. These challenges consist of the decisions they have to make about the curriculum materials and the design process. In order to deal with these challenges, teachers need to find, select and apply relevant strategies to tackle the design challenges. This ability to tackle design challenges is affected by teachers' prior expertise in curriculum design for collegial purposes, their pedagogical content knowledge and their curriculum design expertise.

However, most teachers have limited prior experience in curriculum design and struggle with conducting curriculum design processes. In order to successfully conduct curriculum design activities, teachers need to have the opportunity to develop their curriculum design expertise and PCK. Teacher involvement in a TDT provides teachers with various opportunities to learn about curriculum design and the curriculum reform, which helps to develop their curriculum design expertise and PCK. These opportunities are the result of conducting analysis, design, implementation and evaluation activities and experiencing what it takes to conduct these activities. Teachers learn to make decisions about the design process and the curriculum materials and subsequently experience the influence of their choices on classroom implementation. Some activities seem to have more potential to develop teachers' curriculum design expertise. These activities include using exemplary materials, sharing experiences about the design process with teachers outside the 
TDT, evaluating the curriculum materials and using the materials in classroom practices. The potential of carrying out design activities for developing curriculum design expertise is not yet fully utilised by TDTs, because some design activities, such as analysis and evaluation, are hardly conducted by TDTs.

Thus, although teacher involvement offers opportunities to develop teachers' curriculum design expertise, their involvement in a TDT as such is often not enough. Just-in-time support offered to TDTs has to focus on the activities that are not (yet) part of teachers' repertoire. In addition support needs to fit the context, the teachers' need for support, their expectations regarding the type of support, and the support needs to be attuned to the progress of the design process taking place in the TDT. External support offered by a facilitator to the TDT needs to stimulate discussions about the design of the curriculum materials and collaborative reflections on the design decisions and the overall design process. Furthermore, support can be offered in the form of concrete tools that a TDT can guide during the design process, such as exemplary curriculum materials (e.g., language tasks, assessment rubrics), design templates (for vision documents, language tasks, assessment rubrics) and guidelines for evaluation activities.

\subsection{REFLECTIONS ON THE RESEARCH METHOD}

\subsubsection{General approach: mixed method}

All four sub-studies were conducted in a realistic context, with teams of teachers collaborating in the design and implementation of a curriculum reform for a period of two years.

For this reason a longitudinal mixed method research approach was considered appropriate for answering the research question posed in this study (Leech \& Onwuegbuzie, 2009). The longitudinal nature of the study made it possible to cover the whole design process using qualitative and quantitative measures. Where other qualitative studies in this particular field focus on certain parts of the design process, this study covered all design activities of the TDTs. This prolonged nature of the case studies helped to get an in-depth understanding of the design activities that were conducted in TDTs and the support activities that were provided. By examining how teachers' experienced these activities it was possible to determine what opportunities TDTs provide for developing teachers' curriculum design expertise. 
Because this study took place in a realistic context practical issues arose while preparing and conducting the studies. First, the selection of the cases was a complex process, because TDTs independently determined what their main focus of the design process would be. This made it more difficult to select TDTs that were in the same phase of the design process. Second, the realistic context affected the data collection. Some TDTs discontinued the process, because schools were closing down or new projects were initiated within the school at the expense of the CEFR-project. In addition, individual teachers changed schools, resulting in teachers leaving TDTs and new ones entering. By using a mixed method approach the implications of these data collection issues for the outcomes of the study were limited, because by combining the outcomes of the qualitative and quantitative measures a better understanding of what opportunities TDTs provide to develop teachers' curriculum design expertise emerged.

The longitudinal multilevel approach addressed the start, middle and end of the project. By collecting data over time using three administrations, the effect of time on teachers' ability to tackle could be identified. Nevertheless, to get an even more precise understanding of how teachers' ability to tackle design challenges changes over time one or two additional administrations during a two-year process would be useful.

By applying a mixed methods approach it was intended to limit the constraints of small-scale qualitative studies only. The case studies not only provided in-depth understanding of teachers' design activities in TDTs, they also informed the quantitative study by identifying the factors that potentially seem to affect teachers' ability to tackle design challenges. The combination of qualitative and quantitative measures therefore resulted in more robust outcomes of the study.

\subsubsection{Storyline method}

The storyline method was used to capture teachers' reflection on the design and support activities in the second (chapter 3) and third study (chapter 4). This method offers teachers the opportunity to reflect on a longer period of time (Beijaard et al., 1999). However, the reconstruction of and reflection on events taking place over an extended period of time is also difficult for the respondents. Therefore, the storyline approach as used by Beijaard et al. (1999) and Handelzalts (2009) has been adapted for this study. Teachers were supported in drawing their storylines by offering an overview of all design and support meetings. This helped them to recall the 
process. To prevent the overview from steering teachers in a certain direction, all statements were posed neutral (e.g., 'support meeting about analysis activities'). While clarifying their lines, teachers shared positive and negative experiences of the design and support meetings and were critical on the (outcomes of the) conducted activities. Adding stimulated recall in the storyline approach helped avoid the negative effects of reflecting on a prolonged period of time.

Another key element in the storyline approach was adopted from Handelzalts (2009), who invited teachers to collaboratively reflect on the design process. Each teacher in the TDT first drew their own personal storyline and when all lines were drawn the teachers explained their line to their colleagues. They explained fluctuations on the line and elaborated how they experienced the design and support meetings. After each teacher had clarified the line, the commonalities and differences between the lines were identified by the main researcher. Next, the teachers responded to each other's lines and clarifications and explained what they learned from the activities. This adopted version of the storyline approach provided crucial additional and relevant information about the teachers' design and support activities. Based on these findings and the experiences with this method in this study, this collaborative part further supports the storyline approach in getting more in-depth results.

\subsubsection{Role of the researcher}

This study was focused on a systematic reconstruction of the design processes of TDTs. For this reason the researcher attended the design and support meetings of the TDTs, attended the meetings of the facilitators, and collected additional data alongside the project. At various stages in the design process of the TDTs, the researcher presented the (preliminary) findings of the study to the teachers and the facilitators, with the aim to inform them about the progress of the TDTs' design process. Teachers and facilitators welcomed the findings from the researchers, because it helped them to further plan the design process and to attune support to the progress of the design process. Sharing the preliminary results of the study with the main stakeholders during the project also helped to bridge the often observed gap between research and practice (e.g., Jochems, 2012; Van Braak \& Vanderlinde, 2012; Voogt, McKenney, Fisser, \& Van Braak, 2012). 


\subsection{REFLECTION ON THE OUTCOMES OF THE STUDY}

\subsubsection{Teachers as designers}

Although teachers are used to adapting existing materials to fit their context and learners (Cviko, Mckenney \& Voogt, 2013; Forbes, 2009; Remillard, 1999, 2005), designing curriculum materials that encompass a curriculum reform at subject level is a more complex design task that is often new to them. This study showed that teachers are able to fulfil the role of designer regarding this complex task under the condition that they could collaborate in a TDT and received sufficient support (cf. Handelzalts, 2009). This study showed that teachers' curriculum design expertise is being developed by being actively involved in conducting design activities. However, in contrary to the study of Cviko, McKenney and Voogt (2014), where teachers in TDTs adopted the designer role to design a series of lesson activities in the context of ICT use to foster early literacy education in kindergarten, this study showed that when involved in more complex design task teachers need additional support. This support, in particular, needs to help them (more than was the case in this study) in planning and performing analysis and evaluation activities, because these activities are not provided by TDTs as such.

By taking up the role as designer, teachers not only developed their curriculum design expertise, but also their PCK. In this study, teachers needed their PCK to develop a deep understanding of the reform framework (CEFR) and how to integrate the curriculum materials they were to design within the reform framework. Although the (few) exemplary curriculum materials assisted in developing an understanding of the design task and improved their understanding of the curriculum reform, teachers needed their (existing) PCK to come up with ideas for the curriculum materials which had to be developed.

\subsubsection{Curriculum design expertise}

In this study, the concept of curriculum design expertise was used to identify which knowledge and skills teachers as designers need to have in order to conduct curriculum design activities (cf. Huizinga, 2009; Nieveen \& Van der Hoeven, 2011). Curriculum design expertise is, together with teachers' subject matter knowledge and pedagogical content knowledge, part of teachers' specific design expertise. The findings of this study revealed convincing evidence about 
teachers' curriculum design expertise and which aspects of curriculum design expertise teachers need to further develop.

In this study curriculum design expertise has been conceptualised as the ability to conduct a systematic and iterative approach to curriculum design. The underlying rationale for this conceptualization is that this approach helps to prevent that important design activities are neglected in the design process (Gustafson, 2002; Gustafson \& Branch, 2002; Smith \& Ragan, 2005). The assumption of this study was that when teachers have a comprehensive understanding of the curriculum design process, they can better plan and operationalise the design activities. Furthermore, they can monitor whether all design activities are conducted, and are able to identify if important design activities are ignored. Within this systematic and iterative approach teachers can still integrate a more pragmatic or prototypical approach to curriculum design, since understanding curriculum design as a systematic and iterative approach does not imply a linear approach which prescribes when to conduct which design activities. The results of this study showed that teachers' have an incomplete conceptual understanding of curriculum design processes, resulting in TDTs skipping important and relevant design activities. To develop a comprehensive understanding of curriculum design as a systematic and iterative approach TDTs need additional external support (see 6.5.3).

\subsubsection{Developing curriculum design expertise}

\section{Working in TDTs}

During this study, teams of teachers worked together on the design and implementation of a curriculum reform. This approach offered opportunities for teacher learning about the reform and about curriculum design (cf. Penuel et al., 2007; Voogt et al., 2011). Teacher learning about curriculum design is especially fostered when teachers have the opportunity to reflect on the design process and share their reflections with colleagues (cf. Hall \& Hord, 2010). The findings of this study demonstrated that explication of the design process and the intentions with the designed materials to their colleagues in the TDTs, their fellow teachers outside the TDT, and to colleagues from other schools are powerful means for improving teachers' understanding and expertise in curriculum design (cf. Hall \& Hord, 2010; Hardré et al., 2006; Hardré, 2009; Voogt et al., 2011). Therefore, TDTs need to conduct these kinds of explication and reflection activities during the design process. 
In this study, it was examined whether the way collaboration in the team was perceived to have affected teachers' ability to tackle design challenges. The findings as presented in the fourth study (chapter 5) showed that this was not the case. However, the fourth study (chapter 5) did not examine whether involvement in a TDT fosters teacher learning about the reform and about curriculum design and if this collaborative learning affects teachers' ability to tackle design challenges. To further improve the understanding of the influence of team factors on teachers' ability to tackle design challenges, scales about collaborative learning in teams need to be added to the model.

\section{External support}

Supporting TDTs during their effort to collaboratively design and implement curriculum materials is vital (cf. Handelzalts, 2009; Nieveen et al., 2005; Patton et al., 2012; Voogt et al., 2011). Support does not only foster the design process, but also offers additional opportunities for teacher learning about curriculum design and the pedagogy and the subject matter. The findings of this study underline that teachers as designers have a specific need for support to overcome design challenges and to develop quality curriculum materials. The need for support includes developing teachers' curriculum design expertise and PCK. This study showed that teachers need support throughout the whole design process, and in particular for conducting analysis and evaluation activities (cf. Handelzalts, 2009; Kerr, 1981). Such support can be offered by external facilitators, but also in the form of tools and templates to help teachers conduct concrete design activities (such as templates for selecting materials and tools to conduct a formative evaluation of the materials with students).

Oftentimes support to TDTs is offered by an external facilitator, which was also the case in this study. When an external facilitator is involved, the style of support offered needs to be attuned with the TDT and their expectations (cf. Odenthal, 2003). Two facilitating styles were used to support the TDTs in this study (see chapter 3), namely a proactive and reactive support style. The proactive support style aimed at improving teachers' conceptual understanding of curriculum design by attuning the support meetings to the stages of the ADDIE-model. The reactive support style had a just-in-time nature and was attuned to the progress of the TDT. Since the support characterised by the first style was not always aligned with the progress of the TDT and the support featured in the second style was not always levering a more systematic approach, the support provided in both cases 
could have been improved when both styles were combined. It seems essential to offer support that is attuned to the progress of the TDTs' design process and helps the TDTs to structure the overall design process (Linder, 2011; Patton et al., 2012).

The number of support meetings offered to the TDTs in this study was limited to six meetings, which, however, mainly took place during the analysis and design phase. Minimal support was offered during the implementation and evaluation phase of the project. The findings of this study suggest that not necessarily more support is needed, but that the support needs to be better distributed across the whole design process with a particular focus on when and how to conduct analysis and evaluation activities.

\section{Curriculum design expertise of facilitators}

Given the importance of support offered by an external facilitator, it is essential that the facilitators themselves have a deep understanding of curriculum design. Facilitators need to be able to plan and conduct analysis, design, evaluation and implementation activities and provide teachers relevant insights in how to conduct the activities in the school context. They also need to be able to identify to which stage of the ADDIE model the design activities relate. The facilitators in this study varied in their facilitating style due to the different views they had concerning the support of TDTs, and possibly as a result of their own curriculum design expertise. Facilitators need to know which design processes fit the context in which TDTs work. Therefore, a facilitator is expected to identify which design approach is best applicable and relevant for the TDT given the aim of the design process and the contextual boundaries. 


\subsection{RECOMMENDATIONS}

\subsubsection{Recommendations for practice}

The study was conducted to identify what opportunities TDTs provide to develop teachers' curriculum design expertise. Based on the findings of this study, recommendations for supporting TDTs and for pre- and in-service teachers are offered.

\section{Recommendation for supporting TDTs}

The main recommendations consist of three guidelines for facilitators offering support to TDTs and three guidelines for the support agencies the facilitators work for.

- Offer just-in-time support to TDTs, to provide the right support on the right time during the TDTs' curriculum design process.

- Attune support to teachers' prior expertise in curriculum design and pedagogy and to their expectations of support throughout all stages of the design process.

- Appoint an informant in the TDT who informs the facilitator about the progress in the design process and the encountered design challenges.

- Reflect with the TDT to what extent they found the offered support relevant and meaningful for their design process.

o Provide exemplary materials and design templates that reflect the reform when TDTs start designing materials.

- Pay specific attention to teachers' analysis and evaluation skills, because it is not part of teachers' repertoire.

- Provide opportunities for teachers to conduct analysis and evaluation activities and reflect with the TDT on the outcomes of the conducted activities.

- Offer analysis and evaluation guidelines and instruments.

- Provide opportunities for exchanging knowledge, skills and experiences with members outside the TDT, to achieve a more effective implementation and to foster teacher learning.

- Provide opportunities to let teachers present their design process to teachers inside and outside their school.

- Provide opportunities to TDTs to share designed materials and examples how the materials work in classroom practice. 
When support is offered to TDTs often a facilitator is involved. The results of this study suggested that facilitators sometimes struggled with offering just-in-time support. Therefore, a few additional recommendations can be made for the support agencies to help facilitators in their support process:

- Develop facilitator's curriculum design expertise to better attune support to TDTs' needs and expectations.

- Provide opportunities to facilitators to collaboratively prepare and offer support.

- Let facilitators (who offer support to TDTs in different context) share support materials and exchange expertise about supporting TDTs.

- Discuss how (new) design challenges of TDTs can be tackled and which support can be offered to achieve this.

- Develop a basic facilitator's toolkit for supporting TDTs, in order to provide just-in-time support during the design process that is attuned to the curriculum reform at hand.

- Include a 'menu card' from which the facilitators can select support activities and materials.

- Include exemplary materials and templates in the toolkit that reflect the curriculum reform.

- Provide analysis and evaluation instruments that TDTs can use.

- Attune and discuss the facilitating style to TDTs in order to effectively facilitate the curriculum design process within TDTs and prevent false expectations within TDTs of the role of the facilitator.

- Clarify the role of the facilitator during the design process to all members of the TDTs.

- Inform the members of TDTs when the role of the facilitator changes.

\section{Developing pre- and in-service teachers' curriculum design expertise}

Given the growing attention of teachers fulfilling the role of designer, both preand in-service teachers need to develop their curriculum design expertise. Based on the findings of this study the following recommendations can be made:

- Explore to what extent pre-service teachers can be prepared to collaboratively design curriculum materials, because this enables them to be actively involved in curriculum reform and to build curriculum ownership.

- Identify how pre-service teachers' conceptual and practical understanding of systematic curriculum design is developed.

o Determine how pre-service teachers learn to evaluate curriculum materials. 
- Encourage pre- and in-service teachers to develop their curriculum design expertise by involving them in TDTs, as this is an important expertise in their (future) job.

- Involve pre- and in-service teachers in TDTs consisting of teachers from different schools to let them develop additional insights about the design process.

- Support both pre- and in-service teachers during their design effort by offering just-in-time support.

- Stimulate classroom implementation of the designed curriculum materials, to provide pre- and in-service teachers with feedback to revise the curriculum materials and to offer additional opportunities for teacher learning.

- Offer pre-service teachers the opportunity to practice the enactment of the designed materials during their internship, which also helps to develop their pedagogical content knowledge.

- Promote the evaluation of classroom implementation to both pre- and inservice teachers.

\subsubsection{Recommendations for future research}

The current study revealed the opportunities that TDTs provide to develop teachers' curriculum design expertise. Yet there is still additional research needed to unravel the black box of developing teachers' curriculum design expertise. Based on the outcomes of this study, the following issues seem worthwhile to explore in the future.

- Further unpack the black box of design and support activities, in order to identify the effective characterises of curriculum design processes.

- Identify the working mechanism of the design and support activities.

- Analyse the design talk of teams related to the specific design activities to shed light on how teachers' curriculum design expertise is developed.

- Develop additional instruments to identify how teachers can learn from conducting curriculum design processes.

- Explore how expertise is shared within and among teachers during collaboration in the TDT and investigate the influence of the characteristics of the team on the development of teachers' curriculum design expertise. 
- Examine learning processes in TDTs in order to determine how curriculum design processes foster the development of teachers' curriculum design expertise and PCK.

- Investigate further how sharing experiences with other TDTs help to develop teachers' curriculum design expertise.

- Explore how proactive and reactive support can be improved to foster the development of teachers' curriculum design expertise.

- Identify whether proactive, reactive or a combination of both styles is most promising for developing teachers' curriculum design expertise. 


\section{REFERENCES}

Agyei, D. D. (2012). Preparation of pre-service teachers in Ghana to integrate information and communication technology in teaching mathematics. Doctoral dissertation, University of Twente, Enschede, The Netherlands.

Akomaning, E. (2012). Improving student internship through collaborative curriculum design in Ghanaian polytechnics. Doctoral dissertation, University of Twente, Enschede, The Netherlands.

Alayyar, G. M. (2011). Developing pre-service teacher competencies for ICT integration through design teams. Doctoral dissertation, University of Twente, Enschede, The Netherlands.

Angeli, C. \& Valanides, N. (2009). Epistemological and methodological issues for the conceptualization, development, and assessment of ICT-TPCK: Advance in technological pedagogical content knowledge (TPCK). Computers \& Education, 52, 154-168.

Anto, A. G., (2013). Collaborative teacher professional development in Ethiopian higher education: The case of communicative language teaching. Doctoral dissertation, University of Twente, Enschede, The Netherlands.

Bakah, M. A. B., Voogt, J. M., \& Pieters, J. M. (2012). Advancing perspectives of sustainability and large-scale implementation of design teams in Ghana's polytechnics: Issues and opportunities. International Journal of Educational Development, 32, 787-796.

Ball, D., \& Cohen, D. (1996). Reform by the book: what is - or might be - the role of curriculum materials in teacher learning and instructional reform? Educational Researcher, 25(9), 6-8, 14.

Barrows, H. S., \& Kelson, A. M. (1993). Problem-based learning: A total approach to Education. Springfield, IL: Southern Illinois University School of Medicine. Available online at: http://wed.siu.edu/Faculty/bputnam/584/PBL\%20Document.pdf, accessed June 5, 2012.

Beijaard, D., Van Driel, J., \& Verloop, N. (1999). Evaluation of story-line methodology in research on teachers' practical knowledge. Studies in Educational Evaluation, 25, 47-62.

Beneson, G., \& Piggott, F. (2002). Introducing technology as a school subject: A collaborative design challenge for educators. Journal of Industrial Teacher Education, 39(3), 67-87.

Ben-Peretz, M. (1990). The teacher-curriculum encounter: Freeing teachers from the tyranny of texts. New York: State University of New York Press.

Beyer, C. J. (2009). Using reform-based criteria to support the development of preserivce elementary teachers' pedagogical design capacity for analyzing science curriculum materials. Doctoral dissertation, Ann Arbor, MI: University of Michigan.

Beyer, C., \& Davis, E. A. (2009). Using educative curriculum materials to support preservice elementary teachers' curricular planning: A comparison between two different forms of support. Curriculum Inquiry, 39(5), 679-703. 
Beyer, C., \& Davis, E. A. (2012). Learning to critique and adapt curriculum materials: Examining the development of preservice elementary teachers' pedagogical content knowledge. Science Education, 96(1), 130-157.

Bolam, R., McMahon, A., Stoll., L., Thomas, S., Wallace, M., Greenwood, A., Hawkey, K., Ingram, M., Atkinson., A., \& Smith, M. (2005). Creating and sustaining effective professional learning communities. Bristol: DfES GTCE NCSL.

Borko, H. (2004). Professional development and teacher learning: Mapping the terrain. Educational Researcher, 33(8), 3-15.

Brandes, G. M., \& Seixas, P. (1998). Subjects and disciplines: Asymmetries in a collaborative curriculum development project. Teachers and Teaching: Theory and Practice, 4(1), 95-114.

Brown, M., \& Edelson, D. C. (2003). Teaching as design: Can we better understand the ways in which teachers use materials so we can better design materials to support their changes in practice? Evanston, IL: The Center for Learning Technologies in Urban Schools.

Carlgren, I. (1999). Professionalism and teachers as designers. Journal of Curriculum Studies, 31(1), 43-56.

Centré Européen de Language Francaise (n.d.). Understanding our course levels. Available at: http://www.alliancefr.be/en/niveaux.html, accessed August 8, 2014

Chastain, T., \& Elliott, A. (2000). Cultivating design competence: Online support for beginning design studio. Automation in Construction, 9, 83-91.

Christensen, T. K., \& Osguthrope, R. T. (2004). How do instructional-design practitioners make instructional-strategy decisions? Performance Improvement Quarterly, 17(3), 45-65.

Clandinin, D. J., \& Connelly, F. M. (1992). Teacher as curriculum maker. In P. Jackson (Ed.), Handbook of research in curriculum (pp. 363-401). New York: MacMillan.

Clarke, D. J., \& Hollingsworth, H. (2002). Elaborating a model of teacher professional growth. Teaching and Teacher Education, 18(8), 947-967.

Cochran, K. F., King, R. A., \& De Ruiter, J. A. (1991). Pedagogical content knowledge: A tentative model for teacher preparation. Paper presented at the Annual Meeting of the American Educational Research Association (Chicago).

Cochran-Smith, M., \& Lytle, S. L. (2009). Inquiry as stance: Practitioner research for the next generation. New York: Teacher College Press

Coenders, F (2010). Teachers' professional growth during the development and class enactment of context-based chemistry student learning material. Doctoral dissertation, University of Twente, Enschede, The Netherlands.

Council of Europe (2001). Common European Framework of Reference for Languages: Learning, teaching, assessment. Cambridge: Cambridge University Press.

Craig, C. J. (2009). Research in the midst of organized school reform: Versions of teacher community in tension. American Educational Research Journal, 46(2), 598-619.

Crain, R. W., Davis, D. C., Calkins, D. E., \& Gentili, K. (1995). Establishing engineering design competencies for freshman/sophomore students. Paper presented at the Frontiers in Education Conference (Atlanta).

Crow, G. M., \& Pounder, D. G. (2000). Interdisciplinary teacher teams: Context, design, and process. Educational Administration Quarterly, 36(2), 216-254. 
Cumming, C. (2011). CPD: Support strategies for professional learning, national initiatives and major curriculum reform. Improving Schools, 14(2), 145-155.

Cviko, A., McKenney, S. E., \& Voogt, J. M. (2013). The teacher as re-designer of a technology integrated curriculum for emergent literacy. Journal of Educational Computing Research, $48(4), 447-468$.

Cviko, A., McKenney, S. E., \& Voogt, J. M. (2014). Teacher roles in designing technology-rich learning activities for early literacy. Computers \& Education, 72, 68-79.

Da Ponte, J. P. (2012). A practice-oriented professional development programme to support the introduction of a new mathematics curriculum in Portugal. Journal of Mathematics Teacher Education, 15, 317-327.

Darling-Hammond, L., \& McLaughlin, M. W. (1995). Policies that support professional development in an era of reform. Phi Delta Kappan, 76(8), 597-604.

Davidson, L., Schofield, J., \& Stocks, J. (2001). Professional cultures and collaborative efforts: A case study of technologist and educators working for change. The Information Society: An International Journal, 17(1), 21-32.

Davis, E. A., \& Krajcik, J. S. (2005). Designing educative curriculum materials to promote teacher learning. Educational Researcher, 34(3), 3-14.

Deketelaere, A., \& Kelchtermans, G. (1996). Collaborative curriculum development: An encounter of different professional knowledge systems. Teachers and Teaching: Theory and Practice, 2(1), 71-85.

Desimone, L. M. (2009). Improving impact studies of teachers' professional development: Toward better conceptualizations and measures. Educational Researcher, 38(3), 181-199.

Desimone, L. M. (2011). A primer on effective professional development. Phi Delta Kappan, 96(6), 68-71.

DeVellis, R. F. (2003). Scale development: Theory and application (2nd ed.). Thousand Oaks, CA: Sage.

Dick, W., Carey, L., \& Carey, J. O. (1985). The systematic design of instruction. Boston, MA: Allyn \& Bacon.

Eggleston, J. (1980). School-based curriculum development in Britain: A collection of case studies. London: Routledge \& Kegan Paul.

Elizondo-Montemayor, L., Hernández-Escobar, C., Ayala-Aguirre, F., \& Aguilar, G. M. (2008). Building a sense of ownership to facilitate change: The new curriculum. International Journal of Leadership in Education: Theory and Practice, 11(1), 83-102.

Ertmer, P. A., \& Cennamo, K. S. (1995). Teaching instructional design: An apprenticeship model. Performance Improvement Quarterly, 8(4), 43-58.

Forbes, C. T. (2009). Preservice elementary teachers' development of pedagogical design capacity for inquiry: An activity-theoretical perspective. Doctoral dissertation, Ann Arbor, MI: University of Michigan.

Fullan, M. G. (1991). The new meaning of educational change (2 ${ }^{\text {nd }}$ ed.). London: Casell Educational Limited.

Fullan, M. G. (2007). The new meaning of educational change (4th ed.). New York: Teachers College Press. 
Garet, M. S., Porter, A. C., Desimone, L., Birman, B. F., \& Yoon, K. S. (2001). What makes professional development effective? Results from a national sample of teachers. American Educational Research Journal, 38(4), 915-945.

Giles, C., \& Hargreaves, A. (2001). The sustainability of innovative schools as learning organizations and professional learning communities during standardized reform. The Educational Administration Quarterly, 42(1), 124-156.

Goodlad, J. I., Klein, F., \& Tye, K. A. (1979). The domains of curriculum and their study. In J. I. Goodlad, \& Associates (Eds.), Curriculum inquiry. The study of curriculum practice (pp. 4376). New York: Mcgraw Hill.

Green, E. L. (1980). The independent learning in science model of school-based curriculum development. In J. Eggleston (ed.), School-based Curriculum Development in Britain: A Collection of Case Studies (pp. 14-40). London: Routledge \& Kegan Paul.

Guskey, T. R. (2000). Evaluating professional development. Thousand Oaks: Corwin Press.

Gustafson, K. L. (2002). Instructional design tools: A critique and projections for the future. Educational Technology Research and Development, 50(4), 59-66.

Gustafson, K. L., \& Branch, R. M. (2002). Survey of instructional development models (4th ed.). Syracuse: Syracuse University.

Hall, G. E., \& Hord, S. M. (2010). Implementing change: Patterns, principles, and potholes (3rd ed.). New York: Pearson College Division.

Handelzalts, A. (2009). Collaborative curriculum design in teacher design teams. Doctoral dissertation, University of Twente, Enschede, The Netherlands.

Hardré, P. L. (2003). The effects of instructional training on university teaching assistants. Performance Improvement Quarterly, 16(4), 23-39.

Hardré, P. L. (2009). Developing expertise in teaching for higher education: Lessons from the training and development of U.S. teaching assistants. Paper presented at the International Forum: Teaching and Learning as Tools of Progress in Higher Education October 27-28, 2009. Availble online:

http://info.psu.edu.sa/pscw/PSCW/psut12011/Sessions/papers/P26.pdf, accessed August 12, 2014

Hardré, P. L., Ge, X., \& Thomas, M. K. (2006). An investigation of development toward instructional design expertise. Performance Improvement Quarterly, 19(4), 63-90.

Hargreaves, A. (2003). Teaching in the knowledge society. Education in the age of insecurity. New York: Teachers College Press.

Hargreaves, A., \& Dawe, R. (1990). Paths of professional development: Contrived collegiality, collaborative culture, and the case of peer coaching. Teaching and Teacher Education, 6(3), 227-241.

Havnes, A. (2009). Talk, planning and decision-making in interdisciplinary teacher teams: A case study. Teachers and Teaching: Theory and Practice, 15(1), 155-176.

Hoogveld, A. W. M. (2003). The teacher as designer of competency-based education. Doctoral dissertation, Heerlen: Open University The Netherlands.

Hord, S. M. (2004). Learning together leading together: Changing schools through professional learning communities. New York: Teachers College Press. 
Hox, J. J. (2002). Multilevel analysis: Techniques and applications. Mawmah, N.J: Lawrence Erlbauw Associates Inc.

Huberman, M. (1993). The lives of teachers. New York: Techers College Press.

Huizinga, T. (2009). Op weg naar een Instrument voor het Meten van Docentcompetenties voor het Ontwikkelen van Curricula [Towards an Instrument to Measure Teacher's Competencies for the Development of Curricula]. Master thesis, Enschede: University of Twente, The Netherlands.

Huizinga, T., Handelzalts, A., Nieveen, N., \& Voogt, J. M. (2014). Teacher involvement in curriculum design: Need for support to enhance teachers' design expertise. Journal of Curriculum Studies, 46(1), 33-57.

Huizinga, T., Handelzalts, A., Nieveen, N., \& Voogt, J. M. (accepted). Fostering teachers' design expertise in Teacher Design Teams: Conducive design and support activities. The Curriculum Journal.

Huizinga, T., Nieveen, N., Handelzalts, A. \& Voogt, J. M. (2013). Ondersteuning op curriculumontwikkelexpertise van docentontwikkelteams [Support to teacher design teams to foster teachers' curriculum design expertise]. Pedagogische Studiën, 90 (3), 4-20.

Jochems, W. (2012). Onderwijsonderzoek en onderwijspraktijk, once the twain shall meet! [Educational research and educational practice, once the twain shall meet!]. Pedagogische Studiën, 89(6), 411-416.

Kerr, S. T. (1981). How teachers design their materials: Implications for instructional design. Instructional Science, 10, 363-378.

Kessels, J. W. M. (1993). Towards design standards for curriculum consistency in corporate education. Doctoral dissertation, University of Twente, Enschede, The Netherlands.

Kessels, J. W. M. (1999). A relational approach to curriculum design. In J. J. H. Van den Akker, R. M. Branch, K. L. Gustafson, N. Nieveen and T. Plomp (eds), Design approaches and tools in education and training (pp. 59-70). Dordrecht: Kluwer Academic.

Kessels, J. W. M. (2001). Learning in organisations: A corporate curriculum for the knowledge economy. Futures, 33(6), 497-506.

Kessels, J. W. M., \& Plomp, T. (1999). A systematic and relational approach to obtaining curriculum consistency in corporate education. Journal of Curriculum Studies, 31(6), 679-709.

Kirk, D., \& MacDonald, D. (2010). Teacher voice and ownership of curriculum change. Journal of Curriculum Studies, 33(5), 551-567.

Kirkpatrick, D. L. (1979). Techniques for evaluating training programs. Training and Development Journal, June, 178-192.

Kirschner, P., Carr, C., Van Merriënboer, J. J. G., \& Sloep, P. (2002). How expert designers design. Performance Improvement Quarterly, 15(4), 86-104.

Koehler, M. J., \& Mishra, P. (2005). What happens when teachers design educational technology? The development of technological pedagogical content knowledge. Journal of Educational Computing Research, 32(2), 131-152.

Koehler, M. J., \& Mishra, P. (2008). Introducing TPCK. In AACTE Committee on Innovation and Technology (Ed.), The handbook of technological pedagogical content knowledge (TPCK) for educators (pp. 3-29). Mahwah, NJ: Lawrence Erlbaum Associates. 
Koehler, M. J., Mishra, P., \& Yahya, K. (2007). Tracing the development of teacher knowledge in a design seminar: Integrating content, pedagogy and technology. Computers $\mathcal{E}$ Education, 49, 740-762.

Krajcik, J. S., McNeill, K. L., \& Reiser, B. J. (2007). Learning-goal-driven design model: Developing curriculum materials that align with national standards and incorporate project-based pedagogy. Science Education, 92(1), 1-32.

Kreber, C., \& Cranton, P. A. (2000). Exploring the scholarship of teaching. Journal of Higher Education, 71 (4), 476-495.

Kuiper, W., Van den Akker, J., Hooghoff, H., \& Letschert, J. (2006). Curriculum policy and school practice in a European comparative perspective. In J. Letschert (Ed.), Curriculum development re-invented. Proceedings of the invitational conference on the occasion of the 30 years SLO 1975-2005. Leiden, the Netherlands, 7-9 December 2005 (pp. 56-77). Enschede: SLO.

Lee., J. C., Zhang., Z., \& Yin, H. (2011). A multilevel analysis of the impact of a professional learning community, faculty trust in colleagues and collective efficacy on teacher commitment to students. Teaching and Teacher Education, 27(5), 820-830.

Leech, N. L., \& Onwuegbuzie, A. J. (2009). A typology of mixed methods research designs. Quality \& Quantity, 43(2), 265-275.

Lieberman, A. \& Pointer Mace, D. (2008). Teacher learning: The key to education reform. Journal of Teacher Education, 59(3), 226-234.

Linder, S. M. (2011). The facilitator's role in elementary mathematics professional development. Mathematics Teacher Education and Development, 13(2), 44-66.

Little, J. W. (1990). The persistence of privacy: Autonomy and initiative in teachers' professional relations. Teachers College Record, 91(4), 509-536.

Little, J. W. (2003). Inside teacher community: Representations of classroom practice. Teachers College Record, 105(6), 913-945.

Lomos, C., Hofman, R. H., \& Bosker, R. J. (2011). Professional communities and student achievement - a meta-analysis. School Effectiveness and School Improvement: An International Journal of Research, Policy and Practice, 22(2), 121-148.

Loucks-Horsley, S., Hewson, P. W., Love, N., \& Stiles, K. E. (1998). Designing professional development for teachers of science and mathematics. Thousand Oaks, CA: Corwin Press.

Lumpe, A. T. (2007). Research-based professional development: Teachers engaged in professional learning communities. Journal of Science Teacher Education, 18(1), 125-128.

Lunenberg, M. (2002). Designing a curriculum for teacher educators. European Journal of Teacher Education, 25 (2-3), 263-277.

Marks, R. (1990). Pedagogical content knowledge: From a mathematical case to a modified conception. Journal of Teacher Education, 41 (3), 3-11.

Marsh, C., Day, C., Hannay, L., \& McCutcheon, G. (1990). Reconceptualizing school-based curriculum development. New York: The Falmer Press.

McKinney, W. L., \& Westbury, I. (1975). Stability and change: The public schools of Gary, Indiana, 1940-70. In W. A. Reid and D. F. Walker (eds), Case studies in curriculum change: Great Britain and the United States (pp. 1-53). London: Routledge \& Kegan Paul.

McLaughlin, M. W., \& Talbert, J. E. (2006). Building school-based teacher learning communities. Professional strategies to improve student achievement. New York:Teachers College Press. 
Meirink, J. A., Imants, J., Meijer, P. C., \& Verloop, N. (2010). Teacher learning and collaboration in innovative teams. Cambridge Journal of Education, 40(2), 161-181.

Merriam, S. B. (1988). Case Study Research in Education. San Fransisco, CA: Jossey-Bass.

Ministerie van Onderwijs, Cultuur en Wetenschap (2011). Leraar 2020 - een krachtig beroep! Den Haag: Minsterie van Onderwijs, Cultuur en Wetenschap. Avaible online at: http:/ / www.rijksoverheid.nl/documenten-en-publicaties/kamerstukken/2011/05/23/ actieplan-leraar-2020.html, accessed August 8, 2014.

Nelson, W. A., \& Orey, M. A. (1991). Reconceptualizing the instructional design process: Lessons learned from cognitive science. Paper presented at the Annual Meeting of the American Educational Research Association (Chicago).

Nieveen, N. (2009). Formative evaluation in educational design research In T. Plomp \& N. Nieveen (Ed.), An introduction to educational design research (pp. 89-102), Enschede: SLO.

Nieveen, N., \& Folmer, E. (2013). Formative evaluation in educational design research. In T. Plomp \& N. Nieveen (Ed.), Educational design research Part A: An introduction (pp. 152169), Enschede: SLO.

Nieveen, N., Handelzalts, A., Van den Akker, J. J. H., \& Homminga, S. (2005). Teacher design teams: A scenario for school-based curriculum innovation. Paper presented at the ECER, Dublin, Ireland.

Nieveen, N., \& Kuiper, W. (2012). Balancing curriculum freedom and regulation in the Netherlands. European Educational Research Journal, 11(3), 357-368.

Nieveen, N., Van den Akker, J. J. H., \& Resink, F. (2010). Framing and supporting schoolbased curriculum development in the Netherlands. In E. H. Law \& N. Nieveen (Eds.), Schools as curriculum agencies: Asian and European perspectives on school-based curriculum development (pp. 273-283). Rotterdam: Sense publishers.

Nieveen, N., \& Van der Hoeven, M. (2011). Building the curricular capacity of teachers: Insights from the Netherlands. In P. Picard \& L. Ria (Eds.), Beginning teachers: a challenge for educational systems - CIDREE Yearbook 2011 (pp. 49-64). Lyon: ENS de Lyon, Institut français de l'Éducation.

Nieveen, N., Van der Hoeven, M., Ten Voorde, M., Koopmans, A., \& Van Lanschot Hubrechts, V. (2013). Docent als ontwerper: Raamwerk voor doordenking ontwerptaken. [Teacher as designer: Framework for thinking through design tasks]. Enschede: SLO.

Norman, G. R. (1988). Problem-solving skills, solving problems and problem-based learning. Medical Education, 22(4), 279-286.

Odenthal, L. E. (2003). Op zoek naar balans Een onderzoek naar een methode ter ondersteuning van curriculum vernieuwing door docenten [Searching for balance: Researching methods for supporting curriculum renewal by teachers]. Docotoral dissertation, Enschede: University of Twente.

Onderbouw-VO (2009). Blijvend in beweging. Vier jaar onderbouwontwikkeling. Monitor 20052008 [Staying in movement. Four years of development: Yearly evaluations 2005-2008]. Zwolle: Onderbouw-VO.

Onderwijsraad (2014). Een eigentijds curriculum [Acontemporary curriculum]. Den Haag: Onderwijsraad.

Pareja Roblin, N., Ormel, B., McKenney, S., Voogt, J. M., \& Pieters, J. M. (2014). Linking research and practice through teacher communities: A place where formal and practical knowledge meet? European Journal of Teacher Education, 37(2), 183-203. 
Parke, H. M., \& Coble, C. R. (1997). Teachers designing curriculum as professional development: A model for transformational science teaching. Journal of Research in Science Teaching, 38(8), 773-789.

Patton, K., Parker, M., \& Neutzling, M. M. (2012). Tennis shoes required: The role of the facilitator in professional development. Research Quarterly for Exercise and Sport, 83(4), 522-532.

Patton, M. Q. (1987). How to use qualitative methods in evaluation (2nd ed.). London: Sage.

Penuel, W. R., Fishman, B. J., Yamaguchi, R., \& Gallagher, L. P. (2007). What makes professional development effective? Strategies that foster curriculum implementation. American Educational Research Journal, 44(4), 921-958.

Peterat, L. (1993). Collaborating for change: Toward a global home economics education. Journal of Vocational Home Economics Education, 10(2), 63-78.

Reeves, T. C. (2006). How do you know they are learning?: The importance of alignment in higher education. International Journal of Learning Technology, 2(4), 294-306.

Remillard, J. T. (1999). Curriculum materials in mathematics education reform: A framework for examining teachers' curriculum development. Curriculum Inquiry, 29, 315-342.

Remillard, J. T. (2005). Examining key concepts in research on teachers' use of mathematics curricula. Review of Educational Research, 75(2), 211-246.

Richards, J. C. (1991). Content knowledge and instructional practice in second language teacher education. In J. E. Alatis (ed.), Georgetown University round table on languages and linguistics 1991: Linguistics and language pedagogy: The state of the art (pp. 76-99). Georgetown: Georgetown University Press.

Richey, R. C., Fields, D. C., \& Foxon, M. (2001). Instructional design competences: The standards ( $3^{\text {rd }}$ ed.). Syracuse: Clearinghouse on Information \& Technology Syracuse University.

Richey, R. C., Klein, J. D., \& Nelson, W. A. (2004). Developmental research: Studies of instructional design and development. In D. Jonassen (ed.), Handbook of Research for Educational Communications and Technology (2nd ed.) (pp. 1099-1130). Bloomington: Association for Educational Communications \& Technology.

Scriven, M. (1991). Evaluation thesaurus (4th ed.). Newbury Park, CA: Sage.

Schildkamp, K., Poortman, C., \& Handelzalts, A. (submitted). Data teams for school improvement.

Schmidt, D. A., Baran, E., Thompson A. D., Koehler, M. J., Mishra, P. \& Shin, T. (2009). Technological Pedagogical Content Knowledge (TPACK): The development and validation of an assessment instrument for preservice teachers. Journal of Research on Technology in Education, 42(2), 123-149.

Schwab, J. J. (1973). The practical 3: Translation into curriculum. School Review, 81(4), 501-522.

Seels, B., \& Glasgow, Z. (1991). Survey of instructional design needs and competencies. Paper presented at the Annual Convention of the Association for Educational Communication and Technology (Orlando, FL).

Shulman, L. S. (1986). Those who understand: Knowledge growth in teaching. Educational Researcher, 15(2), 4-14.

Shulman, L. S. (1987). Knowledge and teaching foundations of the new reform. Harvard Education Review, 57(1), 1-22. 
Simmie, G. M. (2007). Teacher design teams (TDTs) - building capacity for innovation, learning and curriculum implementation in the continuing professional development of in-career teachers. Irish Educational Studies, 26(2), 163-176.

Skilbeck, M. (1984). School-based curriculum development. London: Harper \& Raw.

Smith, P. L., \& Ragan, T. J. (2005). Instructional design (3rd ed.). New York: Wiley \& Sons.

Snijders, T., \& Bosker, R. (2012). Multilevel analysis: An introduction to basic and advanced multilevel modelling ( $2^{\text {nd }}$ ed.). London: Sage Publications Inc.

Stamos (2014). Werkgelegenheid naar geslacht [Employment per gender]. Retrieved from http://stamos.nl/downloads/Factsheet_werkgelegenheid_onderwijs_naar_geslacht0212 2011.pdf, accessed August 8, 2014.

Stenhouse, L. (1975). An introduction to curriculum research and development. London: Heinemann Educational Books.

Stoll, L., Bolam, R., McMahon, A., Wallace, M., \& Thomas, S. (2006). Professional learning communities: A review of the literature. Journal of Educational Change, 7, 221-258.

Strauss, A., \& Corbin, J. (1998). Basics of qualitative research techniques and procedures for developing grounded theory (2nd ed.). Thousand Oaks, CA: Sage Publications.

Strijker, A., \& Corbalan, G. (2011). Zoeken en arrangeren met leerlijnen [Searching and arranging with curricular frameworks]. Enschede: SLO.

Taba, H. (1962). Curriculum development: Theory and practice. New York: Harcourt Brace and World. Tamir, P. (2004). Curriculum implementation revisited. Journal of Curriculum Studies, 36(3), 281-294.

Thijs, A., \& Van den Akker, J. J. H. (2009). Leerplan in ontwikkeling [Curriculum in development] Enschede: SLO.

Van Braak, J., \& Vanderlinde, R. (2012). Het profiel van onderwijsonderzoekers en hun opvattingen over samenwerking met de onderwijspraktijk [The profile of educational researchers and their beliefs about collaboration with practitioners]. Pedagogische Studiën, 89(6), 364-376.

Van den Akker, J. J. H. (2003). Curriculum perspectives: An introduction. In J. J. H. Van den Akker, W. Kuiper, \& U. Hameyer (Eds.), Curriculum landscapes and trends (pp. 1-10). Dordrecht: Kluwer Academic Publishers.

Van den Akker, J. J. H. (2010). Building bridges: how research may improve curriculum policies and classroom practices. In S. Stoney (Ed.), Beyond Lisbon 2010: Perspectives from research and development for education policy in Europe (pp. 175-195). CIDREE Yearbook 2010. Slough, England: NFER.

Van den Akker, J. J. H., \& Voogt, J. (1994). The use of innovation and practice profiles in the evaluation of curriculum implementation. Studies in Educational Evaluation, 20, 503-512.

Van Driel, J. H., Beijaard, D., \& Verloop, N. (2001). Professional development and reform in science education: The role of teachers' practical knowledge. Journal of Research in Science Teaching, 38, 137-158

Van Driel, J. H., Meirink, J. A., Van Veen, K., \& Zwart, R. C. (2012). Current trends and missing links in studies on teacher professional development in science education: A review of design features and quality of research. Studies in Science Education, 48(2), 129-160.

Van Merriënboer, J. J. G., \& Kirschner, P. (2013). Ten steps to complex learning: A systematic approach to four-component instructional design ( $2^{\text {nd }}$ ed.). New York, NY: Routledge. 
Velthuis, C. (2014). Collaborative curriculum design to increase science teaching self-efficacy. Doctoral dissertation, University of Twente, Enschede, The Netherlands.

Verhagen, P., Kuiper, W., \& Plomp, T. (1999). Onderwijskundig ontwerpen in het onderwijsprogramma van Toegepaste onderwijskunder [Curriculum development in the curriculum of educational designers]. In J. M. Pieters, T. Plomp, \& L. E. Odenthal (Eds.), 20 jaar toegepaste onderwijskunde [20 years of educational design curriculum]. Enschede: Twente University Press.

Verloop, N., \& Lowyck, J. (2003). Onderwijskunde: Een kennisbasis voor professionals [Educational science: A knowledge base for professionals]. Groningen: Wolters- Noordhoff BV.

Vescio, V., Ross, D., \& Adams, A. (2008). A review of research on the impact of professional learning communities on teaching practice and student learning. Teaching and Teacher Education, 24, 80-91.

Visscher-Voerman, J. I. A. (1999). Design approaches in training and education: A reconstructive study. Doctoral dissertation, University of Twente, Enschede, The Netherlands.

Voogt, J., McKenney, S., Fisser, P., \& Van Braak, J. (2012). Naar nieuwe samenwerkingsvormen tussen onderwijsonderzoek en onderwijspraktijk [Towards new forms of cooperation between research and practice]. Pedagogische Studiën, 89(6), 335-337.

Voogt, J., Westbroek, H., Handelzalts, A., Walraven, A., McKenney, S., Pieters, J., \& De Vries, B. (2011). Teacher learning in collaborative curriculum design. Teacher and Teaching Education, 27(8), 1235-1244.

VO-Raad (2014). Klaar voor de toekomst! Samen werken aan onderwijskwaliteit. Sector akkoord VO 2014 - 2017 [Ready for the future! Collaborating on the quality of education. Sectoral agreement secondary education 2014-2017]. Den Haag: VO-Raad.

Walker, D. F. (1975). Curriculum development in an art project. In W. A. Reid and D. F. Walker (eds), Case studies in curriculum change: Great Britain and the United States (pp. 91135). London: Routledge \& Kegan Paul.

Wilhelm, P., \& Wilde, R. (2005). Developing a university course for online delivery based on learning objects: From ideals to compromises. Open Learning, 20(1), 65-81.

Yang, S., Fox, E. A., Wildemuth, B. M., Pomerantz, J., \& Oh, S. (2006). Interdisciplinary curriculum development for digital library education. Digital Libraries: Achievements, Challenges and Opportunities, 4312, 61-70.

Yin, R. K. (2003). Case study research: Design and methods (3 ${ }^{\text {rd }}$ ed.). Thousand Oaks, CA: Sage Publications. 


\section{DUTCH SUMMARY \\ Het ontwikkelen van curriculumontwerpexpertise in DocentOntwikkelTeams}

\section{INTRODUCTIE}

Het ontwerpen en implementeren van curriculumvernieuwingen is een complex proces, dat, ondanks de beste intenties van stakeholders, vaak niet de beoogde veranderingen teweegbrengt. Om het ontwerp- en implementatieproces te bevorderen wordt vaak gepleit voor een actieve rol van de docent bij de vormgeving van de vernieuwing in de eigen school. Deze actieve rol kan tot uiting komen door docenten naast de rol van uitvoerende ook die van ontwerper van de vernieuwing te geven.

Echter, initiatieven waarin docenten de rol van ontwerper vervullen blijken te vaak niet succesvol. Een belangrijke reden hiervoor is dat docenten niet over voldoende kennis en vaardigheden beschikken om curricula te ontwikkelen voor de eigen onderwijscontext.

De benodigde kennis en vaardigheden voor het ontwikkelen van kwalitatief goede curriculummaterialen worden ontwerpexpertise genoemd. Ontwerpexpertise bestaat uit twee componenten, namelijk generieke ontwerpexpertise en specifieke ontwerpexpertise. Generieke ontwerpexpertise omvat intra-persoonlijke vaardigheden (persoonlijke motivatie en ambitie), interpersoonlijke vaardigheden (samenwerkingsvaardigheden en communicatieve vaardigheden) en procesgerelateerde vaardigheden (plannen en managen van ontwerpprocessen). Specifieke ontwerpexpertise omvat vakinhoudelijke kennis (kennis over feiten, concepten, procedures en principes van het vak), vakdidactische vaardigheden (selecteren, toepassen en aanpassen van vakdidactische strategieën om het leerproces te bevorderen) en curriculumontwerpexpertise (kennis en vaardigheden benodigd voor curriculumontwikkeling en om ontwerpuitdagingen aan te kunnen). In deze studie staat het bevorderen van curriculumontwerpexpertise centraal. 
Curriculumontwerpexpertise kan bevorderd worden door docenten actief deel te laten nemen aan DocentOntwikkelTeams (DOTs). Docenten die deelnemen aan DOTs hebben de mogelijkheid om kennis te delen en te ontwikkelen en gezamenlijk oplossingen te bedenken voor de ontwerpuitdagingen die ze tegenkomen. Met name wanneer docenten reflecteren op de uitgevoerde ontwerpactiviteiten ontstaan er mogelijkheden om hun ontwerpexpertise te vergroten.

Binnen dit onderzoek hadden 15 DOTs (op het terrein van moderne vreemde talen docenten in het voortgezet onderwijs) de taak om het Europees ReferentieKader voor de Talen (ERK) te implementeren in de eigen schoolcontext. Elke DOT bestond uit docenten moderne vreemde talen van één school. Gedurende een tweejarig traject ontwikkelden ze taaltaken, beoordelingsrubrics en visiedocumenten aansluitend bij het ERK en de schoolcontext. Hun doel was het ERK te integreren in het moderne vreemde talen curriculum. Tijdens het ontwerp- en implementatieproces ontving elke DOT ondersteuning van een curriculumontwikkelaar van SLO, het nationaal expertisecentrum leerplanontwikkeling. De aangeboden ondersteuning was afgestemd op de wensen en behoeften van de DOTs.

\section{DOEL VAN DE STUDIE EN ONDERZOEKSVRAGEN}

Alhoewel er hoge verwachtingen zijn over de potentie van DOTs om de curriculumontwerpexpertise van docenten te bevorderen is er weinig bekend over welke ontwerp- en ondersteuningsactiviteiten in DOTs de benodigde curriculumontwerpexpertise van docenten bevorderen. Deze studie had tot doel om dit inzicht te vergroten.

De hoofdonderzoeksvraag was:

Welke mogelijkheden bieden DOTs aan docenten om hun curriculumontwerpexpertise te bevorderen? 
Om de hoofdonderzoeksvraag te beantwoorden zijn vier deelstudies uitgevoerd. In de deelstudies stonden de volgende onderzoeksvragen centraal:

1. Wat is de behoefte aan ondersteuning van DOTS tijdens het gezamenlijk ontwikkelen van lessenseries?

2. Welke ontwerp- en ondersteuningsactiviteiten binnen DOTs bevorderen de ontwikkeling van curriculumontwerpexpertise van docenten?

3. Welke implementatie- en evaluatieactiviteiten tijdens de ontwikkeling van een nieuw curriculum bieden mogelijkheden om de curriculumontwerpexpertise van docenten te bevorderen?

4. Welke (persoonlijke, team en management) factoren beïnvloeden de verandering in vaardigheden van docenten om ontwerpuitdagingen op te lossen gedurende het verloop van het werk van het DOT?

\section{ONDERZOEKSOPZET}

De vier deelstudies zijn opgezet aan de hand van de vier deelvragen. In de eerste deelstudie zijn de behoeften aan ondersteuning van DOTs geïnventariseerd. Docenten binnen de DOTs en hun ondersteuners zijn gevraagd om te reflecteren op uitgevoerde ontwerpprocessen en aan te geven op welk vlak en op welke wijze de specifieke ontwerpexpertise van docenten bevorderd kan worden.

In de tweede deelstudie stonden de ontwerp- en ondersteuningsactiviteiten van twee DOTs centraal. Deze teams, van twee verschillende scholen, hadden de taak om het ERK te integreren in het moderne vreemde talen curriculum van hun school. De teams deden dit door taaltaken, beoordelingsrubrics en visiedocumenten te ontwikkelen. Het ene team bestond uit vijf docenten en het andere team uit zestien docenten. De studie had betrekking op het eerste jaar van het ERK project. In deze deelstudie is geanalyseerd welke analyse-, ontwerp-, en ontwikkelactiviteiten en welke ondersteuning hebben bijgedragen aan de bevordering van curriculumontwerpexpertise van docenten binnen de DOTs.

In de derde deelstudie stonden de implementatie- en evaluatieactiviteiten van drie DOTs centraal. De DOTs hadden tot doel om de ontworpen materialen uit het eerste jaar van het ERK-project in de lespraktijk te implementeren en te evalueren. De uitgevoerde implementatie- en evaluatieactiviteiten en de door docenten gehanteerde kennis en vaardigheden zijn geanalyseerd. 
De vierde deelstudie had tot doel om factoren te identificeren die invloed hebben op de ontwikkeling van de vaardigheden van docenten om met ontwerpuitdagingen om te gaan en ze op te lossen. De docenten van de 15 DOTs hebben gedurende het tweejarige ERK-project op drie momenten een vragenlijst ingevuld. Deze data zijn gebruikt voor de ontwikkeling van een multilevel-model waaraan persoonlijke, team- en managementfactoren volgens een stapsgewijze benadering zijn toegevoegd.

\section{Methodologie}

Voor het beantwoorden van de hoofdvraag is een mixed method aanpak gehanteerd. In de eerste deelstudie is een cross-sectionele aanpak toegepast. In de tweede en derde deelstudies is een case study aanpak gehanteerd en in de vierde deelstudie is een longitudinale kwantitatieve aanpak toegepast.

Voor het beantwoorden van de onderzoeksvragen van de eerste drie deelstudies is gebruik gemaakt van kwalitatieve data. In de eerste deelstudie zijn de percepties van zes docenten uit DOTs en zes ondersteuners van DOTs met elkaar vergeleken. De data werden verzameld door middel van een semigestructureerd interviewschema waarin het ontwerpproces, de ontwerpuitdagingen, hoe deze ontwerpuitdagingen werden opgelost en de aangeboden ondersteuning centraal stonden. In de tweede deelstudie zijn vijf instrumenten en een artefact gebruikt om de data te verzamelen. De instrumenten bestonden uit semigestructureerde interviewschema's (één voor docenten en één voor de ondersteuners), een observatieschema voor de ontwerp- en ondersteuningsbijeenkomsten, contact summary sheets en de storyline methode. Het artefact was het e-mailverkeer tussen de docenten en de ondersteuners. In de derde deelstudie zijn ook vijf instrumenten en een artefact gebruikt om de data te verzamelen. Deze instrumenten waren de storyline methode, een observatieschema voor de ontwerpbijeenkomsten, een semigestructureerd interviewschema voor de ondersteuner, een observatieschema voor de lesuitvoering en een semigestructureerd interviewschema voor de docenten. Het artefact was de uitgevoerde taaltaak van de geobserveerde les. In zowel de tweede als derde deelstudie is gebruik gemaakt van a-priori coderen. 
Om de vierde deelvraag te beantwoorden zijn kwantitatieve data verzameld. Er is gebruik gemaakt van een vragenlijst waarin de docenten hun eigen vaardigheden beoordeelden met betrekking tot het oplossen van ontwerpuitdagingen (onafhankelijke variabele), persoonlijke factoren (vakdidactische kennis en vaardigheden, curriculumontwerpexpertise en eerdere ervaringen met curriculumontwikkeling), teamfactoren (samenwerking in het DOT) en managementfactoren (het belang van ondersteuning van het management en de ontvangen ondersteuning van het management) De kwantitatieve data zijn op drie momenten gedurende het tweejarige ERK-project verzameld: bij aanvang, na één jaar en aan het eind van het project en zijn geanalyseerd door het toepassen van een longitudinale multilevel analyse.

\section{Resultaten}

De resultaten van de eerste deelstudie toonden aan dat docenten ondersteuning nodig hebben om hun curriculumontwerpexpertise en hun vakdidactische kennis en vaardigheden te ontwikkelen. Om dit te bereiken hebben docenten just-in-time ondersteuning nodig vanaf het begin van het ontwerpproces. Docenten hebben vooral behoefte aan sjablonen (templates), leerlijnen en richtlijnen voor het opzetten en uitvoeren van evaluaties om de kwaliteit van de ontwikkelde curriculummaterialen te bepalen.

Uit de tweede deelstudie bleek dat de curriculumontwerpexpertise van docenten bevorderd kan worden door het uitvoeren van ontwerp- en ondersteuningsactiviteiten. De ondersteuning dient aan te sluiten bij het doel van het ontwerpproces van de DOTs en bij de voorkennis van docenten op het gebied van curriculumontwikkeling. Om de curriculumontwerpexpertise te bevorderen dient (1) de ondersteuning direct toepasbaar te zijn in het ontwerpproces (bijv. voorbeeldmaterialen en sjablonen), (2) er aandacht te zijn voor evaluatieactiviteiten (screening en collegiale feedback) vanaf het begin van het ontwerpproces en (3) de mogelijkheid geboden te worden dat docentontwerpers hun ervaringen met het ontwerpproces, de gemaakte keuzes en de materialen te delen met collega's buiten het DOT.

De resultaten van de derde deelstudie laten zien dat docenten door het uitvoeren van implementatie- en evaluatieactiviteiten een beter begrip kregen van het belang van het bevorderen van het eigenaarschap van de materialen bij de 
collega's buiten het ontwerpteam. Om dit te bereiken hebben ze gezamenlijke voorbereidingsactiviteiten uitgevoerd, deelden ze eigen ervaringen over de lesimplementatie met collega's en boden ze voorbeeldmaterialen en videoopnames aan van uitgevoerde lessen. De resultaten toonden daarnaast aan dat docenten amper aandacht besteedden aan evaluaties en dat de evaluaties die hebben plaatsgevonden onvoorbereid en ongestructureerd waren. Bovendien was de focus bij deze evaluaties uitsluitend gericht op de praktische uitvoerbaarheid van de materialen.

De vierde deelstudie toont aan dat de vaardigheden van docenten om met ontwerpuitdagingen om te gaan wordt beïnvloed door persoonlijke factoren, en dan vooral hun eerdere ervaringen met het ontwikkelen van curriculummaterialen die ook gebruikt gaan worden door collega's (zowel binnen als buiten de eigen school), hun vakdidactische kennis en vaardigheden en de curriculumontwerpexpertise. In tegenstelling tot uitkomsten van eerdere kwalitatieve studies bleken de team- en managementfactoren in deze studie geen invloed te hebben gehad op de vaardigheden van docenten om met ontwerpuitdagingen om te gaan.

\section{CONCLUSIES}

Op grond van deze studie kan worden geconcludeerd dat docentontwerpers met verschillende ontwerpuitdagingen worden geconfronteerd wanneer ze curriculummaterialen in DOTs ontwikkelen. Deze uitdagingen hebben betrekking op de curriculummaterialen zelf en op het uit te voeren ontwerpproces. Om hiermee om te gaan moeten docenten kennis maken met diverse passende ontwerpstrategieën, en deze selecteren en toepassen in de praktijk. Het omgaan met ontwerpuitdagingen wordt beïnvloed door eerdere ervaringen in curriculumontwikkeling voor collegiaal gebruik, hun vakdidactische kennis en vaardigheden en hun curriculumontwerpexpertise.

Hoewel docenten vaak wel (enige) ervaring hebben met het ontwikkelen van curriculummaterialen, hebben ze moeite met het uitvoeren van ontwerpprocessen. Het werken in DOTs biedt verschillende mogelijkheden om de benodigde expertise te ontwikkelen. Zij worden dan in de gelegenheid gesteld om analyse-, ontwerp-, ontwikkel-, implementatie- en evaluatieactiviteiten uit te voeren en ervaren wat er allemaal nodig is om curriculummaterialen te 
ontwikkelen. In deze studie leerden docenten om beslissingen te nemen over de curriculummaterialen en het ontwerpproces. Daarnaast leerden ze welke invloed deze keuzes hadden op het gebruik van de curriculummaterialen in de klas.

Sommige activiteiten binnen de DOTs lijken meer potentie te hebben om de curriculumontwerpexpertise te bevorderen dan andere activiteiten. Deze activiteiten betreffen het gebruikmaken van voorbeeldmaterialen, het delen van ervaringen over het ontwerpproces met docenten buiten het ontwerpteam, het evalueren van de curriculummaterialen en het gebruiken van de materialen in de lespraktijk.

Aan de hand van deze studie kan geconcludeerd worden dat de mogelijkheden om de curriculumontwerpexpertise van docenten te bevorderen door middel van DOTs nog niet optimaal worden benut. Om deze mogelijkheden te optimaliseren is het essentieel dat docenten just-in-time ondersteuning krijgen wanneer ze in DOTs werken. Deze ondersteuning dient de nadruk te leggen op activiteiten die nog niet standaard in het repertoire van docenten zitten, zoals de analyse- en evaluatieactiviteiten en het delen van de ervaringen met collega's buiten de DOTs. Daarnaast dient de ondersteuning afgestemd te zijn op de context (o.a. randvoorwaarden) waarbinnen de ondersteuning wordt aangeboden en dient de ondersteuning afgestemd te zijn op de ondersteuningsbehoefte, de verwachtingen van de docenten ten aanzien van de ondersteuningsstijl en de voortgang van het ontwerpproces van het DOT. Dit kan bereikt worden door de discussies over het ontwerpproces te bevorderen en gezamenlijk te reflecteren op de genomen beslissingen met betrekking tot het ontwerp en het ontwerpproces. Tot slot kan het ontwerpproces gestructureerd worden door concrete tools aan te bieden om het werk van de DOTs te ondersteunen. 


\section{APPENDICES}

\section{APPENDIX A}

Data collection instrument for chapter 2 (semi-structured interview faciliators)

Behoefteanalyse - Ondersteuners

Datum:

\begin{tabular}{|l|l|}
\hline \multicolumn{2}{|l|}{ Algemene karakteristieken van de participant } \\
\hline Naam: & \\
\hline Organisatie: & \\
\hline (hoofd)vakgebied: & \\
\hline $\begin{array}{l}\text { Aantal jaar ervaring met } \\
\text { ondersteuning: }\end{array}$ & \\
\hline
\end{tabular}

Ervaring met betrekking tot één van de ontwikkelprojecten

1. Kunt een beeld schetsen van een ontwikkelproject binnen het leergebied Mens \& Maatschappij die uitgevoerd wordt door docenten?

2. Op welke wijze wordt $u$ door de docententeams benaderd om ondersteuning op te zetten (algemeen beeld)?

Overstijgende behoefte van docententeams en aangeboden ondersteuning

3. Kunt $\mathrm{u}$ voorbeeld geven van de wijze waarop u keuzes maakt voor het opstellen van ondersteuning?

4. Welke activiteiten/ondersteuningsvormen staan vast? (m.a.w. wat biedt $\mathrm{u}$ altijd aan)

5. Welke werkvormen en activiteiten biedt $u$ aan tijdens het ondersteunen? (workshops, sturende rol, opdrachten etc.)

6. Uitgaande van een ontwikkelproject van +/- 6 maanden, in welke mate biedt $u$ ondersteuning aan (frequentie)? Hoe wordt dit bepaald?

7. Op welke moment (of momenten) neemt de frequentie toe?

8. Heeft de inhoud van de ondersteuning een bepaald zwaartepunt op het proces of het product? Waardoor komt dit?

9. Op welke wijze hebben de docenten zelf invloed op de ondersteuning die geboden wordt?

Ervaring ondersteuning

10. In welke mate evalueert $\mathrm{u}$ de ondersteuning die $\mathrm{u}$ heeft aangeboden?

11. In hoeverre heeft de aangeboden ondersteuning invloed op de duur van het project?

12. Welke reacties heeft $\mathrm{u}$ ontvangen op de door $\mathrm{u}$ aangeboden ondersteuning?

13. Welke tips zou u meegeven wanneer er ondersteuning ontworpen zou moeten worden met betrekking tot arrangeren? 


\section{APPENDIX B}

Data collection instrument for chapter 2 (semi-structured interview teachers)

Behoefteanalyse - docenten

Datum:

\begin{tabular}{|l|l|}
\hline Algemene karakteristieken van de participant \\
\hline Naam: & \\
\hline School: & \\
\hline (hoofd)vakgebied: & \\
\hline Aantal jaar lesgeefervaring: & \\
\hline $\begin{array}{l}\text { Andere taken naast } \\
\text { lesgeven: bij }\end{array}$ & \\
\hline $\begin{array}{l}\text { Betrokkenheid } \\
\text { ontwikkelprojecten }\end{array}$ & \\
\hline
\end{tabular}

Ervaring met betrekking tot één van de ontwikkelprojecten

1. Kunt $\mathrm{u}$ een kort beeld schetsen van het project waaraan $\mathrm{u}$ heeft meegewerkt? (aantal deelnemers, doel van het project, leerjaar etc.)

2. Wat is de aanleiding voor het project geweest?

3. Op welke wijze bent $\mathrm{u}$ betrokken geraakt bij de ontwikkeling?

4. Wat zijn de uitkomsten van het project (type materialen, reacties leerlingen, leeropbrengsten etc.)?

Facilitering en ondersteuning tijdens het project

5. Op welke wijze is het project vanuit de school gefaciliteerd (tijd en financieel))?

6. Op welke wijze kreeg u feedback over het ontwikkelde project? (bijv. critical friends)

7. Heeft $\mathrm{u}$ ondersteuning gekregen van een externe organisatie? (Zo ja, welke organisatie en hoe is deze organisatie betrokken geraakt bij het project? Indien Nee, naar gewenste ondersteuning)

8. Kunt $\mathrm{u}$ een beschrijving geven van de wijze waarop $\mathrm{u}$ ondersteund bent tijdens het ontwikkelen (activiteiten, vorm etc.)?

9. Op welke wijze heeft de ondersteuning bijgedragen aan het (1) proces en (2) product?

10. Wat waren de twee meest nuttige activiteiten en welke twee zou u weggelaten hebben?

Gewenste ondersteuning

11. Wat heeft $\mathrm{u}$ aan ondersteuning gemist tijdens het ontwikkelen?

12. Als $\mathrm{u}$ zelf ondersteuning zou mogen ontwikkelen, welke vorm zou deze dan hebben?

13. Op welke vlakken had wenst $u$ ondersteuning te ontvangen tijdens het ontwikkelen? (n.a.v. competentieschema)

14. Welke activiteiten tijdens het ontwikkelen moeten ondersteuning krijgen? 


\section{APPENDIX C}

Codebook used during the data analysis of chapter 2

\begin{tabular}{|c|c|}
\hline Code & Uitleg bij de code \\
\hline PROJECT-AANTAL-DEELNEMERS & $\begin{array}{l}\text { Beschrijft het aantal deelnemers dat aan het ontwikkelproject hebben } \\
\text { meegedaan, eventueel onderscheid maken tussen docenten en externe } \\
\text { betrokkenen }\end{array}$ \\
\hline PROJECT-ROLLEN-DEELNEMERS & De verschillende rollen die door de docenten worden vervuld \\
\hline PROJECT-DOEL & $\begin{array}{l}\text { Beschrijving van het doel van het ontwikkelproject (bijv. integratie van } \\
\text { vakken). }\end{array}$ \\
\hline PROJECT-LEERJAAR & Beoogd leerjaar waarvoor het is ontwikkeld (bijv. eerste klas) \\
\hline PROJECT-NIVEAU & Het niveau waarvoor ontwikkeld is (VMBO, HAVO, VWO) \\
\hline PROJECT-BETROKKEN-VAKKEN & De vakken die bij het project betrokken zijn (elk vak apart toekennen) \\
\hline $\begin{array}{l}\text { PROJECT-TIJDSDUUR- } \\
\text { ONTWIKKELEN }\end{array}$ & De tijdsduur van het project \\
\hline PROJECT-RESULTAAT & De opbrengst van het project (materialen, etc.) \\
\hline $\begin{array}{l}\text { AANLEIDING-ONVREDE- } \\
\text { METHODE }\end{array}$ & Aanleiding van het project is onvrede over de gebruikte methode \\
\hline $\begin{array}{l}\text { AANLEIDING-BEHOEFTE- } \\
\text { LEERLINGEN }\end{array}$ & Aanleiding van het project is (nieuwe) behoefte van leerlingen \\
\hline $\begin{array}{l}\text { AANLEIDING-SCHOOL-BREDE- } \\
\text { VERNIEUWING }\end{array}$ & Aanleiding van het project is een schoolbrede vernieuwing \\
\hline AANLEIDING-EIGEN-INITIATIEF & Aanleiding is eigen initiatief om eens "wat anders" te doen \\
\hline AANLEIDING-ANDERS & Andere aanleiding \\
\hline BETROKKEN-INITIATOR & Betrokken geraakt vanwege initiatorrol \\
\hline BETROKKEN-EIGEN & Betrokken geraakt vanwege eigen keuze \\
\hline BETROKKEN-AANGESTUURD & Betrokken geraakt vanwege aangewezen vanuit management \\
\hline BETROKKEN-ANDERS & Op een andere manier betrokken geraakt \\
\hline UITKOMST-MATERIAAL-TRAD & Uitkomst zijn traditionele materialen (bijv. lesboeken, papieren lesbrieven) \\
\hline UITKOMST-MATERIAAL-DIGI & $\begin{array}{l}\text { Uitkomst zijn digitale materialen (webquest, powerpoints, onderdelen op } \\
\text { ELO's etc) }\end{array}$ \\
\hline UITKOMST-MATERIAAL-COMBI & Diversiteit aan materialen \\
\hline UITKOMST-LEERLING-POS & Reacties leerling positief op uitkomsten project \\
\hline UITKOMST-LEERLING-NEU & Reacties leerling neutraal op uitkomsten project \\
\hline UITKOMST-LEERLING-NEG & Reacties leerling negatief op uitkomsten project \\
\hline UITKOMST-LEEROPBR-POS & Leeropbrengsten leerlingen vooruit gegaan \\
\hline UITKOMST-LEEROPBR-NEU & Leeropbrengsten gelijk gebleven \\
\hline UITKOMST-LEEROPBR-NEG & Leeropbrengsten achteruit gegaan \\
\hline FACILITERING-TIJD & School heeft ontwikkeltijd beschikbaar gesteld \\
\hline FACILITERING-GELD & School heeft geld beschikbaar gesteld voor het aanschaffen van materialen \\
\hline FACILITERING-OVERIG & Overige vormen van faciliteren die aangeboden worden \\
\hline $\begin{array}{l}\text { FEEDBACK- } \\
\text { MEDEONTWIKKELAAR }\end{array}$ & Feedback ontvangen van een docent uit het ontwikkelteam \\
\hline FEEDBACK-DOCENTEN-SCHOOL & Feedback ontvangen van docenten binnen de eigen school \\
\hline FEEDBACK-DOCENTEN-EXTERN & Feedback ontvangen van docenten van andere scholen \\
\hline FEEDBACK-ANDERS & Andere vorm van feedback op materialen ontvangen \\
\hline $\begin{array}{l}\text { EXTERNE-ONDERSTEUNING- } \\
\text { AANWEZIG }\end{array}$ & Tijdens het project is ondersteuning aanwezig \\
\hline $\begin{array}{l}\text { EXTERNE-ONDERSTEUNING- } \\
\text { AFWEZIG }\end{array}$ & Tijdens het project is ondersteuning afwezig \\
\hline $\begin{array}{l}\text { EXTERNE-ONDERSTEUNING- } \\
\text { NAAM }\end{array}$ & Naam van de instelling die project heeft ondersteund \\
\hline $\begin{array}{l}\text { ONTVANGEN- } \\
\text { ONDERSTEUNING-ACTIVITEIT }\end{array}$ & Activiteit die aangeboden is ter ondersteuning \\
\hline
\end{tabular}




\begin{tabular}{|l|l|}
\hline $\begin{array}{l}\text { ONTVANGEN- } \\
\text { ONDERSTEUNING- } \\
\text { [COMPGROEP] }\end{array}$ & $\begin{array}{l}\text { Voor elke subgroep (bv. curriculum design expertise) wordt de ontvangen } \\
\text { ondersteuning gedefinieerd. }\end{array}$ \\
\hline $\begin{array}{l}\text { BIJDRAGE-ONDERSTEUNING- } \\
\text { PROCES }\end{array}$ & (Verwachte) invloed van de ondersteuning op het proces \\
\hline $\begin{array}{l}\text { BIJDRAGE-ONDERSTEUNING- } \\
\text { PRODUCT }\end{array}$ & (Verwachte) invloed van de ondersteuning op het product \\
\hline ACTIVITEIT-MEEST-NUTTIG & Ondersteuning die positief ontvangen is \\
\hline ACTIVITEIT-WEGLATEN & Ondersteuning die negatief ontvangen is \\
\hline $\begin{array}{l}\text { ONDERSTEUNING-GEMIST- } \\
\text { PROCES }\end{array}$ & Ontbrekende ondersteuning m.b.t. proces \\
\hline $\begin{array}{l}\text { ONDERSTEUNING-GEMIST- } \\
\text { PRODUCT }\end{array}$ & Ontbrekende ondersteuning m.b.t. product \\
\hline $\begin{array}{l}\text { ONDERSTEUNING-GEMIST- } \\
\text { ANDERS }\end{array}$ & Ontbrekende ondersteuning m.b.t. anders \\
\hline $\begin{array}{l}\text { ONDERSTEUNING-VORM- } \\
\text { DIGITAAL }\end{array}$ & Ondersteuning via digitale (omgeving) vorm \\
\hline $\begin{array}{l}\text { ONDERSTEUNING-VORM- } \\
\text { PROCESBEGELEIDER }\end{array}$ & Ondersteuning in de vorm van een procesbegeleider \\
\hline $\begin{array}{l}\text { ONDERSTEUNING-VORM- } \\
\text { ONTWERPBEGELEIDER }\end{array}$ & Ondersteuning in de vorm van een ontwerpbegeleider \\
\hline $\begin{array}{l}\text { ONDERSTEUNING-VORM- } \\
\text { ANDERS }\end{array}$ & Andere vorm van ondersteuning \\
\hline $\begin{array}{l}\text { ONDERSTEUNING-GEWENST- } \\
\text { [COMPGROEP] }\end{array}$ & Gewenste ondersteuning heeft betrekking op competentiegroep \\
\hline $\begin{array}{l}\text { ONDERSTEUNING- } \\
\text { NOODZAKELIJK-ACTIVITEIT }\end{array}$ & Noodzakelijk ondersteuning activiteit \\
\hline
\end{tabular}




\section{APPENDIX D}

Data collection instrument for chapter 3 and 4

\section{Reflectief interview ondersteuners - Voor niet zelf bijgewoonde bijeenkomsten}

Naam ondersteuner + school

Datum ondersteuning

Datum interview

\section{Korte typering ondersteuningsdag}

Hoeveel docenten waren er aanwezig en wat was hun rol (bijv. kartrekkers, co-ontwerper etc.)?

In welke mate waren de docenten gefaciliteerd om de ondersteuning mee te maken? (werden de docenten nog gestoord voor andere zaken?)

In welke mate was de locatie waar de ondersteuning werd aangeboden geschikt?

Wat waren de kernonderwerpen die besproken werden tijdens dit ondersteuningsmoment?

\section{Ondersteuningsactiviteiten}

Kun je een beeld schetsen van de activiteiten die uitgevoerd zijn?

Typering van de activiteiten (doel, groeping, rol van de ondersteuner)

Hoe reageerden docenten op de aangeboden activiteiten?

Welke problemen/aandachtspunten werden door de docenten geuit?

Zijn er nog "huiswerkopdrachten" aangeboden aan de docenten voor de volgende keer?

Welke activiteiten zou je bij een andere locatie ook weer gaan aanbieden?

\section{Bepaling ondersteuning}

Op welke wijze heb je besloten welke activiteiten je ging aanbieden?

Welke invloed hadden het intakegesprek, uitwisselingen met de contactpersoon en de eigen inschatting hierop?

\section{Producten}

Welke producten heeft het team al ontwikkeld?

Wat vond je in het algemeen van de kwaliteit van deze producten?

Wat waren de grootste knelpunten/problemen in de producten?

\section{Reflectie}

Welke activiteiten gingen er voor je gevoel goed? (dus sloten aan bij de docenten) Welke activiteiten zou je de volgende keer anders aanbieden? 


\section{APPENDIX E}

Data collection instrument for chapter 3 and 4

\section{Reflectief interview docenten - Voor niet zelf bijgewoonde bijeenkomsten}

Naam ondersteuner + school

Datum ondersteuning

Datum interview

\section{Korte typering ondersteuningsdag}

Kunt u een korte beschrijving geven van de ondersteuningsdag (bijv. aantal docenten aanwezig, hun rol, rol van de SLO'er etc.)

In welke mate was u gefaciliteerd om de ondersteuning mee te maken? (was u bijv. vrijgeroosterd?)

Wat vond u van de locatie waar de bijeenkomst was georganiseerd?

Wat waren de kernonderwerpen die besproken werden tijdens dit ondersteuningsmoment?

\section{Ondersteuningsactiviteiten}

Kunt $\mathrm{u}$ een beeld schetsen van de activiteiten die uitgevoerd zijn?

Typering van de activiteiten (doel, groeping, rol van de ondersteuning)

Wat vond $u$ van deze activiteiten?

Welke problemen/aandachtspunten kwamen aan de orde?

Op welke wijze heeft $\mathrm{u}$ in de weken na de ondersteuning nog gebruik gemaakt van de opgedane kennis?

\section{Invloed op bepaling ondersteuning}

In welke mate had $\mathrm{u}$ invloed op de activiteiten die aangeboden werden?

\section{Producten}

Welke producten (denk aan taaltaken, pta, leerlijnen, et cetera) heeft $\mathrm{u}$ op dit moment ontwikkeld?

Op welke wijze heeft $\mathrm{u}$ de kwaliteit van deze producten gewaarborgd?

Welke bijdrage had de aangeboden ondersteuning hierop?

\section{Reflectie}

Welke activiteiten vond $\mathrm{u}$ aansluiten bij uw behoeften?

Wat zou u graag een volgende keer anders zien? 
APPENDIX F

Data collection instrument for chapter 3 and 4

Observatieschema ontwerpmoment

Naam school

Datum ontwerpmoment

Algemene karakteristieken

\begin{tabular}{|l|l|l|l|}
\hline $\begin{array}{l}\text { Start bijeenkomst } \\
\text { (tijdstip) }\end{array}$ & $\begin{array}{l}\text { Einde bijeenkomst } \\
\text { (tijdstip) }\end{array}$ & \\
\hline Aantal docenten & & Locatie & \\
\hline Centrale onderwerp(en) & & & \\
\hline
\end{tabular}

\begin{tabular}{|l|l|}
\hline Tijdstip & Beschrijving activiteit/opmerking \\
\hline & \\
& \\
& \\
\end{tabular}


APPENDiX G

Data collection instrument for chapter 3 and 4

\section{Contact summary sheet}

Contact type:

Tijdens ontwerpdag

Tijdens ondersteuningsdag

Contactpersoon:
School:

Datumcontact

Datum verwerkt:

Genoteerd door:

1. Wat waren de centrale onderwerpen en thema's die besproken zijn?

2. Samenvatting van de informatie op elk onderwerp/thema

3. Andere onderdelen die aan de orde zijn gekomen die belangrijk waren?

4. Aandachtspunten voor aankomend contact 


\section{APPENDIX H}

Data collection instrument for chapter 3 and 4

\section{Reflectie ontwerpproces - Storyline met docenten}

Doel activiteit: Docenten in de mindset van het ERK-project krijgen, zodat ze tijdens het tweede gedeelte zich volledig kunnen focussen op de ondersteuning.

Korte introductie over storyline methode:

- Voor ieder ligt een lege grafiek

- Waarbij op de verticale as van 1 tot 5 loopt, met 3 neutraal beeld, 1 meest negatief en 5 meest positief.

- Je tekent een lijn over de ontwikkeling over het ERK-project

- Het gaat niet om een gevoel, maar om een evaluatie van het proces. Dus hoe is dit ERK-project verlopen

- Begin vanaf de huidige situatie, dus hoe kijk je nu tegen het ERK-project aan.

- Trekt vervolgens de lijn terug in de tijd.

- $\quad$ Eerst tekenen we de lijn individueel.

- Kort voorbeeld van het maken van een lijn (in 2-3 minuten).

- “Hoe waarderen jullie het ERK-project, zoals jullie het doorlopen hebben?"

- Hoe loopt de lijn naar achteren - iedere docent licht zijn lijn na het tekenen toe.

- Wat bepaalt de

- Pieken

- Dalen

- $\quad$ Richting verandering

- Wat zijn de verschillen tussen respondenten ?

-Wat zou er moeten gebeuren om de lijn anders te doen lopen?

\section{Inleiding:}

Korte introductie over het doel van het interview/gesprek, namelijk het terugkijken op de ondersteuning, door middel van te reflecteren op de aangeboden activiteiten, aangeboden informatie en rol van de ondersteuner. Daarnaast wordt dit aangevuld met de wijze waarop dit ervaren is.

Openingsvraag - algemene beeld van de ondersteuning

- Er zijn tot nu toe drie bijeenkomsten met [naam ondersteuner] geweest, kunnen jullie een korte typering geven per bijeenkomst en hoe jullie vonden dat de bijeenkomsten verliepen?

- Wat is jullie algemene beeld van de ondersteuning zoals deze tot nu toe is aangeboden?

- Wat vinden jullie van de kwaliteit van de ondersteuning? (o.a. samenhang van het traject, aansluiting bij voorkennis en behoeften, gehanteerde werkvormen)

- In welke mate hadden jullie contact met [naam ondersteuner] tussen de ondersteuningsmomenten en welke aspecten werden tijdens deze contactmomenten besproken?

Focus van de ondersteuning

- In welke mate hadden jullie invloed op de ondersteuning die aangeboden werd?

- In hoeverre vinden jullie het belangrijk dat dit mogelijk is?

- Wat is in jullie optiek de focus van de ondersteuning? (ERK, ontwerpvaardigheden, vakinhoudelijke kennis, vakdidactische kennis, etc.)

- Op welke wijze is uiteindelijk de focus van de ondersteuning bepaald? (o.a. mate van afstemming binnen het team)

- Wat vinden jullie van deze focus? 
Vorm van de ondersteuning

- Welke ondersteuningsactiviteiten zijn aangeboden?

- Hoe zou je de ondersteuningsactiviteiten typeren en wat was de rol van [naam van de ondersteuner] tijdens deze activiteiten?

- Welke activiteit/bijeenkomst vond je het meest prettig en waarom?

Materialen en middelen van de ondersteuning en invloed op het proces

- Wat voor een materialen en middelen hebben jullie ontvangen tijdens de ondersteuning? (bijv. slides, achtergrondinformatie, formats etc.)

- $\quad$ Per genoemd onderdeel:

- In hoeverre sloten de aangeboden materialen en middelen aan bij jullie voorkennis en behoeften?

○ In welke mate hebben jullie hiervan gebruik gemaakt tijdens het ontwerpproces? (indien niet gebruikt, welke reden lag hieraan ten grondslag?)

- Zijn er nog aanpassingen gemaakt aan de ontvangen materialen en middelen? (en zo ja, welke veranderingen en waarom?)

○ Op welke manier ondersteunde de aangeboden materialen het ontwerpproces?

Afsluiting

Stel jullie mogen zelf ondersteuning aanbieden op een andere school die ook taaltaken gaat ontwikkelen.

- Hoe zou je daar de ondersteuning opzetten?

- Welke rol zou je als ondersteuner vervullen?

- Waarop zou je de ondersteuning focussen?

- Welke onderdelen van de ondersteuning, zoals jullie die tot nu toe ontvangen hebben, zouden jullie daar ook aanbieden?

- Welke onderdelen zouden jullie nog willen toevoegen? 


\section{$\underline{\text { Proces }}$}

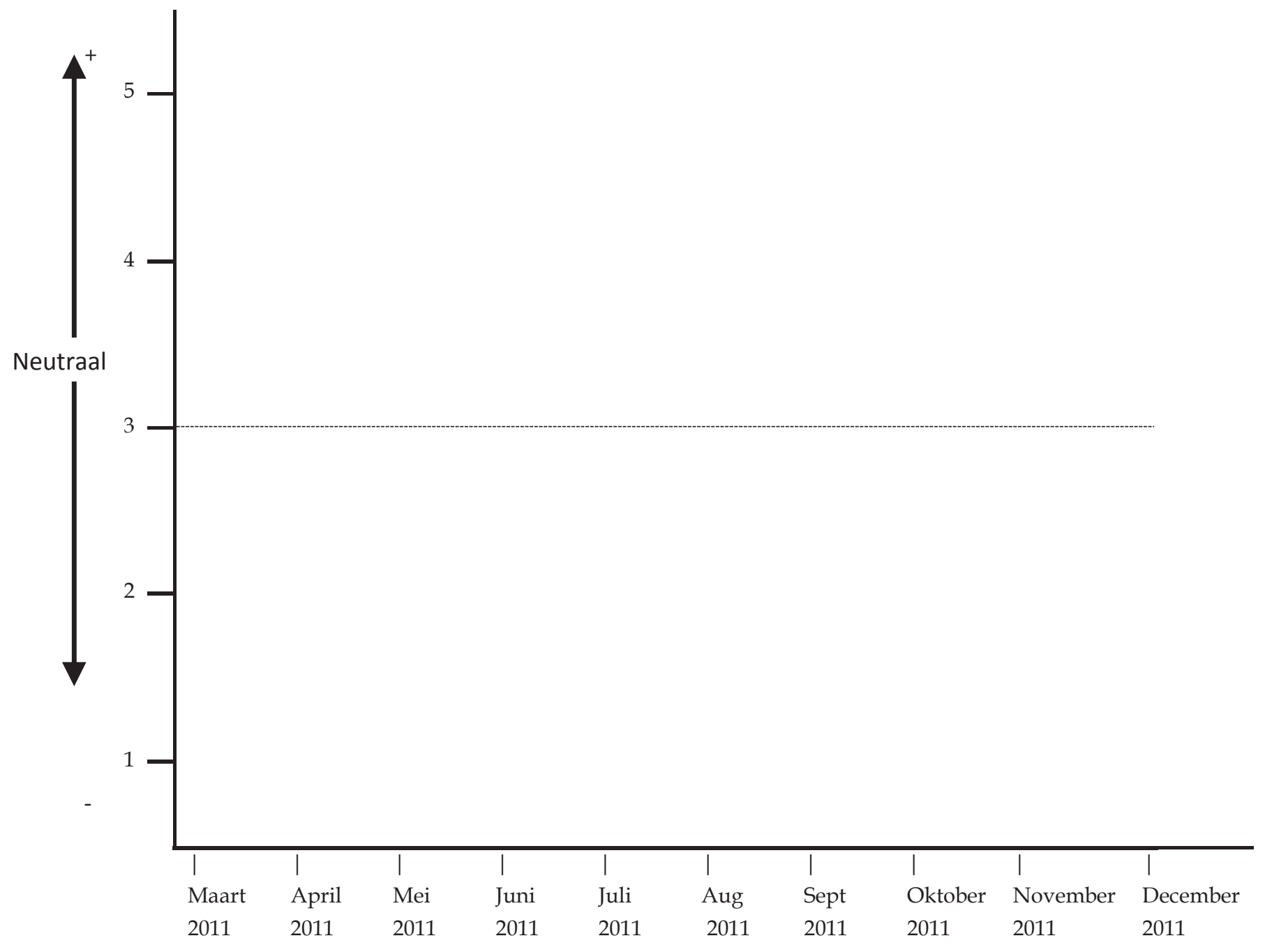


APPENDIX I

Data collection instrument for chapter 3 and 4

\section{Instrument case study - ondersteuner - Reflectief interview over de ondersteuning}

Inleiding:

Korte introductie over het doel van het interview, namelijk het typeren va de ondersteuning door middel van te reflecteren op de rol van de ondersteuner, de focus van de ondersteuning, de vorm van de ondersteuning en de gebruikte materialen.

Openingsvraag - algemeen beeld op het ondersteunen van docententeams.

- Wat is jouw optiek de optimale manier om docententeams te ondersteunen? (o.a. mate van sturing door de ondersteuner, rol van de ondersteuner)

- Op welke wijze herken je dit in de wijze waarop je [naam van de scholen] ondersteund hebt?

- Wanneer ga je weg met een tevreden gevoel weg bij een school?

Ervaring op de scholen

- Wat zijn je ervaringen tot nu toe op de scholen?

- Wat zijn de positieve ervaringen? Waardoor komt dat?

- Wat zijn de negatieve ervaringen?

- Welke dingen zou je een volgende keer anders doen?

Focus van de ondersteuning

- In welke mate stuur je de focus van de ondersteuning en in hoeverre betrek je (een deel van) de docenten bij het opstellen van de ondersteuning?

- Wat is in jouw optiek de focus van de ondersteuning die je aan hebt geboden? (ERK, ontwerpvaardigheden, PCK, CK, etc.)

- $\quad$ Op welke wijze koppel je de opzet van de ondersteuning terug met (een deel van) het team?

Vorm van de ondersteuning

- Hoe zou je de ondersteuningsvorm typeren?

- Welke activiteiten bied je aan?

○ Hoe zou je je rol tijdens deze activiteiten beschrijven?

○ Welke bijeenkomst vond je het meest prettig om aan te bieden en waarom?

Materialen en middelen van de ondersteuning

- Zou je per school globaal aan kunnen geven welke materialen en middelen je uitgedeeld hebt ter ondersteuning van de docententeams?

- Op welke wijze heb je besloten om deze materialen aan te bieden?

- Zijn er nog school-specifieke aanpassingen aan gemaakt?

- In hoeverre vraag je om terugkoppeling over de wijze waarop de docenten de materialen en middelen gebruiken?

- Welke aangeboden materialen en/of middelen zou je voor een volgende keer aanpassen?

Afsluiting:

Stel je zou op een andere school binnen het VeldwERK-project ondersteuning aan mogen bieden die met taaltaken wil gaan werken, welke onderdelen van de ondersteuning die je nu hebt aangeboden zou je daar ook (kunnen) gebruiken?

- Welke onderdelen opnieuw gebruiken?

- Welke onderdelen aanpassen?

- Welke onderdelen toevoegen? 
APPENDIX J

Codebook for chapter 3

\begin{tabular}{|l|l|}
\hline Hoofdcatergorie & Beschrijving hoofdcategorie \\
\hline $\begin{array}{l}\text { Curriculum Design } \\
\text { Expertise }\end{array}$ & $\begin{array}{l}\text { Uitgevoerde activiteitein en ondersteuning aangeboden om de } \\
\text { curriculumontwerpexpertise te bevoreden en om de vaardigheden van docenten te } \\
\text { bevorderen om een relationele en systematische ontwerp aanpak uit te voeren ten } \\
\text { einde intern en extern consistente curriculum materialen te ontwikkelen. }\end{array}$ \\
\hline $\begin{array}{l}\text { Pedagogical content } \\
\text { knowledge (PCK) }\end{array}$ & $\begin{array}{l}\text { Uitgevoerde activiteiten en aangeboden ondersteuning om de kennis en } \\
\text { vaardigheden van docenten m.b.t. het ERK te bevorderen en het uitvoeren van } \\
\text { taaltaken in de lespraktijk. }\end{array}$ \\
\hline $\begin{array}{l}\text { Subject matter } \\
\text { knowledge (SMK) }\end{array}$ & $\begin{array}{l}\text { Uitgevoerde activiteiten en aangeboden ondersteuning om de kennis over het ERK te } \\
\text { bevorderen. }\end{array}$ \\
\hline
\end{tabular}

\begin{tabular}{|l|l|l|}
\hline Deelcode & Beschrijving & $\begin{array}{l}\text { Toepassing - Ondersteuning (gericht) } \\
\text { op/ondersteuningsactiviteit over }\end{array}$ \\
\hline CDE-Problem & Probleemdefiniëring & $\begin{array}{l}\text { Kennis en vaardigheden over afbakenen en } \\
\text { opstellen van probleemdefiniëring }\end{array}$ \\
\hline CDE-Idea & Ideeën genereren & $\begin{array}{l}\text { Kennis en vaardigheden over afbakenen en } \\
\text { opstellen van probleemdefiniëring }\end{array}$ \\
\hline CDE-Analyis & Analyse-activiteiten & $\begin{array}{l}\text { Kennis en vaardigheden over analyse-activiteiten } \\
\text { (bv. doelgroep, context, best-practice, etc.) }\end{array}$ \\
\hline CDE-Design & Ontwerp-activiteiten & $\begin{array}{l}\text { Kennis en vaardigheden over ontwerp-activiteiten } \\
\text { (bv. blauwdrukken, ontwerpvoorbeelden, } \\
\text { templates, etc.) }\end{array}$ \\
\hline CDE-Develop & Ontwikkel-activiteiten & $\begin{array}{l}\text { Kennis en vaardigheden over het verder } \\
\text { ontwikkelen van taaltaken }\end{array}$ \\
\hline CDE-Evaluation-for & $\begin{array}{l}\text { Formatieve evaluatie } \\
\text { activiteiten }\end{array}$ & $\begin{array}{l}\text { Kennis en vaardigheden over het uitvoeren en } \\
\text { plannen van formative evaluaties (indien niet } \\
\text { specifiek aangegeven welk type evaluatie, deze } \\
\text { code ook hanteren!) }\end{array}$ \\
\hline CDE-Evaluation-sum & $\begin{array}{l}\text { Summatieve evaluation } \\
\text { activiteiten }\end{array}$ & $\begin{array}{l}\text { Kennis en vaardigheden over het uitvoeren en } \\
\text { plannen van summatieve evaluaties }\end{array}$ \\
\hline CDE-Decision & $\begin{array}{l}\text { Nemen van beslissingen } \\
\text { Kennis en vaardigheden m.b.t. het nemen van } \\
\text { beslissingen (hoe worden de keuzes gemaakt) }\end{array}$ \\
\hline CDE-Implementation & $\begin{array}{l}\text { Implementatie } \\
\text { activiteiten (of } \\
\text { bevordering van } \\
\text { implementatie) }\end{array}$ & $\begin{array}{l}\text { Kennis en vaardigheden over het implementeren } \\
\text { van de gemaakte materialen (bijv. voorbeelden in } \\
\text { de klas, lessuggesties) }\end{array}$ \\
\hline
\end{tabular}




\begin{tabular}{|c|c|c|}
\hline SMK-Update & $\begin{array}{l}\text { Vernieuwen inzichten op } \\
\text { vakinhoudelijk gebied }\end{array}$ & Kennis over het ERK (o.a. niveaus) \\
\hline SMK-LearnerDif & $\begin{array}{l}\text { Inzichten in } \\
\text { moeilijkheden van } \\
\text { leerlingen met vakinhoud }\end{array}$ & Kennis over de moeilijkheden binnen de niveaus \\
\hline PCK-Repertoire & $\begin{array}{l}\text { Inzichten over } \\
\text { vakdidactische repertoire }\end{array}$ & Vakdidactische inzichten over het leren van talen \\
\hline PCK-Material & $\begin{array}{l}\text { Inzichten over het } \\
\text { selecteren van bestaande } \\
\text { materialen }\end{array}$ & $\begin{array}{l}\text { Kennis en vaardigheden over het selecteren van } \\
\text { materialen aansluitend bij de vakdidactiek }\end{array}$ \\
\hline PCK-ICT & $\begin{array}{l}\text { Inzichten over het } \\
\text { selecteren van ICT- } \\
\text { middelen }\end{array}$ & $\begin{array}{l}\text { Kennis en vaardigheden over het inzetten van ICT } \\
\text { in het onderwijs aansluiting bij de vakdidactiek }\end{array}$ \\
\hline CCE-Internal & $\begin{array}{l}\text { Activiteiten ter } \\
\text { bevordering van interne } \\
\text { consistentie (Let op: } \\
\text { overlap met ADDIE } \\
\text { aanwezig) }\end{array}$ & $\begin{array}{l}\text { Kennis en vaardigheden over het ontwikkelen van } \\
\text { materialen die intern consistent zijn (o.a. } \\
\text { curriculaire samenhang, spinnenweb, praktisch } \\
\text { bruikbaar, coherent) }\end{array}$ \\
\hline CCE-External & $\begin{array}{l}\text { Activiteiten ter } \\
\text { bevordering van externe } \\
\text { consistentie (o.a. visie) }\end{array}$ & $\begin{array}{l}\text { Kennis en vaardigheden over het ontwikkelen van } \\
\text { materialen die aansluiten bij de visie van de school } \\
\text { en de andere stakeholders (zelfde visie over } \\
\text { kernconcepten en relationeel ontwikkelen) }\end{array}$ \\
\hline
\end{tabular}




\section{APPENDIX K}

Data collection instrument for chapter 4

Observatieschema - Taaltaak

\begin{tabular}{|l|l|l|l|}
\hline Algemene eigenschappen & Observator & \\
\hline Datum observatie & & Naam Taaltaak & \\
\hline School & & Centrale vaardigheid & \\
\hline Niveau (+ jaar) & & Opstelling van de ruimte & \\
\hline Aantal leerlingen & & & \\
\hline Aanvang les & & Duur van de les & \\
\hline
\end{tabular}

\begin{tabular}{l|l|l|}
$\begin{array}{l}\text { Beschrijving van de uitgevoerde activiteiten } \\
\text { (beschrijving welke lesactiviteiten worden } \\
\text { uitgevoerd, denk aan: introductie op de taak, } \\
\text { houden van een presentatie door een leerling } \\
\text { etc.) }\end{array}$ & Tijdstip in de les & $\begin{array}{l}\text { Rol van de docent } \\
\text { (instructie/sturend/coachend) }\end{array}$ \\
\hline & &
\end{tabular}

\begin{tabular}{|l|l|l|}
\hline $\begin{array}{l}\text { Reacties van de } \\
\text { leerlingen/docent over de taak } \\
\text { (gestelde vragen + mondelinge } \\
\begin{array}{l}\text { uitingen) en over hetgeen } \\
\text { gedaan moet worden door de } \\
\text { leerlingen. }\end{array}\end{array}$ & $\begin{array}{l}\text { Typering reactie } \\
\text { (onduidelijkheden / praktische } \\
\text { beperkingen / taal / aansluiting } \\
\text { doelgroep / context / overig) }\end{array}$ & $\begin{array}{l}\text { Wijze waarop ingegaan wordt door } \\
\text { de docent omgegaan met reacties om } \\
\text { de taak verder af te stemmen }\end{array}$ \\
\hline & & \\
& & \\
\hline
\end{tabular}

Beschrijving van randvoorwaarden waar tegen aangelopen wordt (bijv. beschikbaarheid computers, etc.). 
APPENDIX L

Data collection instrument for chapter 4

Instrument interview n.a.v.les

Interview

- Algemene eigenschappen (aantal jaar lesgeefervaring, aantal jaar bekend met ERK, aantal jaar ervaring met gebruiken taaltaken)

Uitvoeren en evalueren van de lessen

- Algemene indruk van de les.

- In welke mate anders dan gepland?

- Waarom zijn deze aanpassingen doorgevoerd?

- Was de les vergelijkbaar met andere lessen waarin Taaltaken worden gegeven? Waar blijkt dat uit?

- Zijn er school-brede afspraken gemaakt over uitvoeren/hanteren van Taaltaken?

- Toelichting op (last-minute) aanpassingen + reden

- Hoe wordt de les geëvalueerd? Waar letten jullie op?

- Welke aanpassingen worden n.a.v. ervaren les nog doorgevoerd?

Ondersteuningsbehoefte tijdens uitvoeren en evalueren

- Koppeling met de les naar en de door de docent ervaren problemen/uitdagingen.

- Hoe heb je nu deze uitdagingen opgelost?

○ Was ondersteuning op die punten noodzakelijk geweest?

- Welke terugkoppeling zou je van ondersteuner ontvangen?

- Mate waarin docenten ondersteuning wensen tijdens uitvoeren en evalueren?

- Waarop ondersteuning

- Vorm van de ondersteuning

- Welke randvoorwaarden hebben daarnaast het uitvoeren en evalueren bevorderd?
- Contextuele randvoorwaarden
- Afspraken binnen de school
- Ervaring met Taaltaken
○ Overig

Aangeboden ondersteuning

- Mate waarin al ondersteuning is aangeboden m.b.t. uitvoeren en evalueren taaltaken

- Welke ondersteuning

- Waarop ondersteuning

- Vorm van de ondersteuning

- Op welke wijze is deze ondersteuning bepaald?

- Is er een terugkoppeling aan de ondersteuner over de lesuitvoering en de evaluaties?

- In hoeverre heeft de ondersteuner activiteiten uitgevoerd om het uitvoeren en evalueren van de taaltaken te bevorderen? 


\section{APPENDIX M}

Data collection instrument for chapter 4

Instrument case study 2 - ondersteuners - reflectief interview over de ondersteuning tijdens de implementatie en evaluatiefasen

Inleiding

Het interview start met een korte introductie over het doel van het interview. Namelijk het inventariseren van de gewenste en aangeboden ondersteuning. Deze thema's worden belicht vanuit de opzet, de focus en de vorm van de ondersteuning.

\section{Algemeen beeld van ondersteunen van docententeams}

Openingsvraag:

Stel je zou morgen naar een nieuwe school gaan om het ERK te implementeren. Er zijn geen beperkingen vanuit het management opgelegd, waardoor op elk willekeurig tijdstip aan de invoering van het ERK gewerkt kan worden.

- Hoe zou je dan de ondersteuning opzetten (voor A - klein docententeam (tot 8 docenten) en voor B - groter docententeam (meer dan 8 docenten))? (beoogde ondersteuning)

- Wat is het doel van de ondersteuning?

- Welke kernactiviteiten zou je sowieso willen uitvoeren?

- In welke mate (aantal keer bezoeken etc.) zou je de ondersteuning aanbieden?

○ Welke rol zou je als ondersteuner vervullen?

- In welke mate worden de docenten of een deel hiervan betrokken bij het opzetten van de ondersteuning?

- Wanneer ben je tevreden over de ondersteuning (succesvol, welke doelen moeten bereikt zijn)

- In welke mate wordt er in het traject expliciet aandacht besteed aan het implementeren en evalueren van het ontworpen onderwijs?

- In hoeverre komt is je ideale ondersteuning te herkennen op de scholen waar je ondersteuning hebt aangeboden?

Aangeboden ondersteuning (per school)

Terugkijkend op de ondersteuning die je aangeboden hebt op de scholen tijdens het ERK-project en dan vooral ten aanzien van [naam school].

- Wat is de ondersteuningslijn die je aangeboden hebt?

○ Op welke wijze is deze lijn bepaald?

- Hoe sluit deze lijn aan bij de optimale wijze van ondersteunen?

- In welke mate al aandacht voor de invoering in de lespraktijk?

- Welke, voor jou essentiële onderdelen, miste je in de ondersteuning?

- Wat is je algemene beeld van de aangeboden ondersteuning?

- Positieve ervaringen?

- Negatieve ervaringen?

- Aandachtspunten voor een volgende keer?

- Wat was de focus van de individuele bijeenkomsten?

- Hoe is deze focus bepaald? (Gestuurd of op basis van input van de docenten)

○ Op welke wijze wordt de opzet teruggekoppeld aan het docententeam?

- In welke wijze verandert de focus van de bijeenkomsten?

- Wat is de centrale focus bijeenkomst overstijgend? (PCK, ERK, CK, Design Expertise)

- Welke specifieke activiteiten heb je aangeboden om de invoering in de lespraktijk te bevorderen?

○ Op welke manier zijn deze bepaald?

○ In welke mate hebben de docenten hun ervaringen teruggekoppeld? 
- Hoe zou je de ondersteuningsvorm van de bijeenkomsten typeren?

- Waaruit blijkt dat deze vorm aangeboden wordt?

- Welke rol vervul je tijdens de bijeenkomsten? En in hoeverre verandert deze rol gedurende een bijeenkomst?

- Welke materialen en middelen zijn aangeboden om de invoering in de lespraktijk te bevorderen en de invoering te evalueren?

- Op welke wijze is bepaald welke materialen en middelen aangeboden zouden worden?

○ Welke school-specifieke aanpassingen zijn doorgevoerd?

- In hoeverre wordt er om terugkoppeling gevraagd op de wijze waarop docenten de aangeboden materialen gebruiken?

Ervaren ondersteuning

- Wat is je algemene beeld van de aangeboden ondersteuning?

- Vanuit de rol als ondersteuner

- Uitgaande van de reacties van de docenten

- Welke onderdelen zou je in een volgend traject weer toepassen?

- Welke onderdelen zou je willen toevoegen?

- Welke onderdelen van de ondersteuning zijn essentieel voor de succesvolle implementatie en evaluatie van het vernieuwde curriculum? 


\section{APPENDIX N}

Data collection instrument for chapter 4

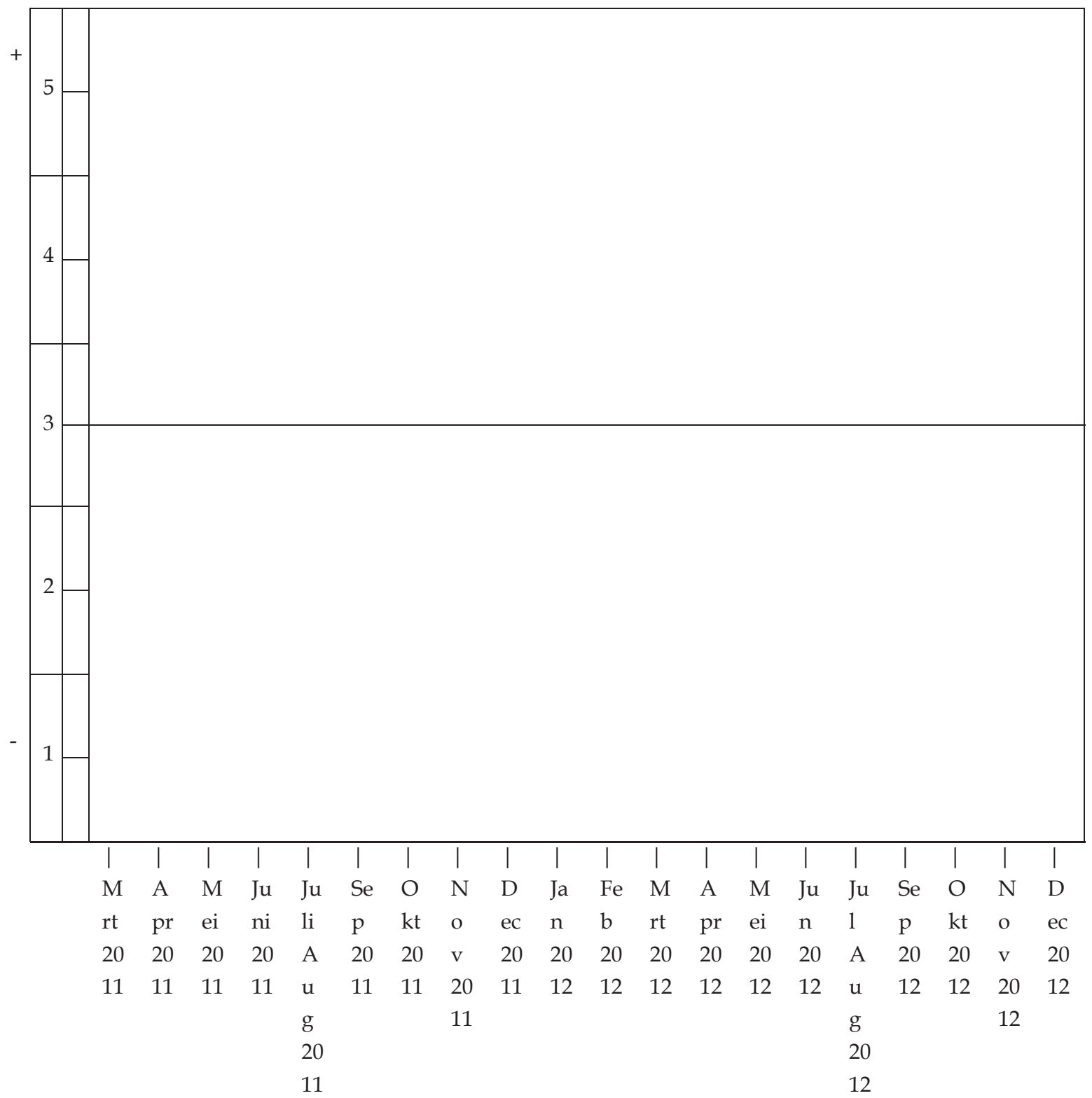




\section{APPENDIX O}

Codebook for chapter 4

\begin{tabular}{|l|l|}
\hline Level 1 & Description \\
\hline TDT-Implementation & $\begin{array}{l}\text { Implementation activity conducted by TDT (e.g., preparation of } \\
\text { using materials in practice) }\end{array}$ \\
\hline TDT-Evaluation & $\begin{array}{l}\text { Evaluation activity conducted by TDT (e.g., reflecting on use in } \\
\text { classroom) }\end{array}$ \\
\hline TDT-Experience-Implementation & $\begin{array}{l}\text { TDT member experience of conducted activity related to using } \\
\text { CEFR in the classroom }\end{array}$ \\
\hline TDT-Experience-Evaluation & $\begin{array}{l}\text { TDT member experience of conducted activity related to } \\
\text { evaluating the use of CEFR in the classroom }\end{array}$ \\
\hline Classroom-Evaluation & Teachers' individual use of CEFR in the classroom \\
\hline Classroom-Experience-Implementation & $\begin{array}{l}\text { Evaluation activities conducted by individual teachers } \\
\text { classroom }\end{array}$ \\
\hline Classroom-Experience-Evaluation & $\begin{array}{l}\text { Teachers' personal experience of carrying out evaluations related } \\
\text { to the use CEFR in his/her own classroom }\end{array}$ \\
\hline
\end{tabular}

\begin{tabular}{|l|l|}
\hline Level 2 & Description \\
\hline $\begin{array}{l}\text { 'TDT-implementation' and 'TDT- } \\
\text { Experience-Implementation' }\end{array}$ & $\begin{array}{l}\text { Conducting activities to enhance ownership (e.g., collaborative } \\
\text { preparation of classroom use, involving stakeholders in design) }\end{array}$ \\
\hline Creating | Enhancing ownership & $\begin{array}{l}\text { Conducting activities required for process management (e.g., } \\
\text { developing planning, monitoring progress) }\end{array}$ \\
\hline Managing implementation process & $\begin{array}{l}\text { Conducting activities in which experiences about the new } \\
\text { curriculum are shared (e.g., piloting the new curriculum, } \\
\text { providing video examples) }\end{array}$ \\
\hline Sharing experiences & $\begin{array}{l}\text { 'TDT-evaluation' and 'TDT-Experience- } \\
\text { Evaluation' }\end{array}$ \\
\hline $\begin{array}{l}\text { Planning, structuring and carrying out } \\
\text { evaluations }\end{array}$ & $\begin{array}{l}\text { Conducting activities require to plan formative and summative } \\
\text { evaluations, product and process evaluations and developing } \\
\text { instruments. }\end{array}$ \\
\hline $\begin{array}{l}\text { Quality criteria and activities for } \\
\text { evaluating products }\end{array}$ & $\begin{array}{l}\text { Activities addressing to identify and determine relevance, } \\
\text { consistency, practicality and effectiveness }\end{array}$ \\
\hline $\begin{array}{l}\text { Analysing outcomes and improving } \\
\text { curriculum }\end{array}$ & $\begin{array}{l}\text { Activities addressing the outcomes of the evaluation and } \\
\text { determining how to improve the curriculum (materials) }\end{array}$ \\
\hline
\end{tabular}




\begin{tabular}{|l|l|}
\hline Level 2 & Description \\
\hline $\begin{array}{l}\text { 'Classroom-Implementation' and } \\
\text { 'Classroom-Experience-Implementation' }\end{array}$ & \\
\hline Aim & Aim of the observed lesson \\
\hline Grouping (of students) & Grouping of the students in the lesson \\
\hline Curriculum materials & Used curriculum materials required to complete the task. \\
\hline Teacher role & Role of the teacher during classroom implementation \\
\hline Student activities & Activities that are conducted in order to complete the task \\
\hline Student role & Role of the student while conducting the task \\
\hline Spoken language & Language spoken during the lesson \\
\hline $\begin{array}{l}\text { 'Classroom-Evaluation' and 'Classroom- } \\
\text { Experience-Evaluation' }\end{array}$ & \\
\hline Carrying out evaluation & $\begin{array}{l}\text { Evaluation activities conducting during classroom } \\
\text { implementation }\end{array}$ \\
\hline $\begin{array}{l}\text { Quality criteria and activities for } \\
\text { evaluating products }\end{array}$ & Specific evaluation criteria address during evaluation. \\
\hline
\end{tabular}


ApPendix $P$

Data collection instrument for chapter 5

\begin{tabular}{|c|c|c|}
\hline $\begin{array}{l}\text { Ability to tackle design } \\
\text { challenges }\end{array}$ & Pedagogical content knowledge & Curriculum design expertise \\
\hline $\begin{array}{l}\text { I believe that I can manage most } \\
\text { design challenges during the } \\
\text { design of curriculum materials }\end{array}$ & $\begin{array}{l}\text { I have various ways and strategies } \\
\text { of developing my understanding } \\
\text { of the language I teach. }\end{array}$ & $\begin{array}{l}\text { After designing I would } \\
\text { systematically evaluate the } \\
\text { curriculum materials by taking } \\
\text { learners' experiences and learning } \\
\text { outcomes into account. }\end{array}$ \\
\hline $\begin{array}{l}\text { I would be able to find and apply } \\
\text { appropriate strategies to tackle } \\
\text { even significant design challenges. }\end{array}$ & $\begin{array}{l}\text { I know how to assess student } \\
\text { performance in a classroom. }\end{array}$ & $\begin{array}{l}\text { During the design I would } \\
\text { systematically evaluate (parts of) } \\
\text { the curriculum materials to } \\
\text { improve the practical usability }\end{array}$ \\
\hline $\begin{array}{l}\text { When I reflect on how I designed } \\
\text { curriculum materials, I feel } \\
\text { achieving. }\end{array}$ & $\begin{array}{l}\text { I can adapt my teaching based } \\
\text { upon what students currently } \\
\text { understand or do not understand. }\end{array}$ & $\begin{array}{l}\text { I would collaboratively generate } \\
\text { ideas with colleagues about how } \\
\text { to make improvements }\end{array}$ \\
\hline $\begin{array}{l}\text { During the design of curriculum } \\
\text { materials I can find strategies to } \\
\text { solve design challenges }\end{array}$ & $\begin{array}{l}\text { I can adapt my teaching style to } \\
\text { different learners. }\end{array}$ & $\begin{array}{l}\text { I would apply an instrumental } \\
\text { approach during the design of our } \\
\text { curriculum materials }\end{array}$ \\
\hline $\begin{array}{l}\text { I have sufficient subject matter } \\
\text { knowledge to design curriculum } \\
\text { materials. }\end{array}$ & $\begin{array}{l}\text { I can assess student learning in } \\
\text { multiple ways. }\end{array}$ & $\begin{array}{l}\text { If I design curriculum materials } \\
\text { than I would focus on the learning } \\
\text { goals, assessment and learning } \\
\text { outcomes. }\end{array}$ \\
\hline \multirow[t]{7}{*}{$\begin{array}{l}\text { When I reflect on how I designed } \\
\text { curriculum materials, I feel } \\
\text { competent. }\end{array}$} & $\begin{array}{l}\text { I can use a wide range of teaching } \\
\text { approaches in a classroom setting } \\
\text { (e.g., collaborative learning, direct } \\
\text { instruction, et cetera). }\end{array}$ & $\begin{array}{l}\text { Prior to the design of curriculum } \\
\text { materials I would define a } \\
\text { problem statement about the } \\
\text { possible improvements. }\end{array}$ \\
\hline & $\begin{array}{l}\text { I am familiar with common } \\
\text { student understandings and } \\
\text { misconceptions. }\end{array}$ & \\
\hline & $\begin{array}{l}\text { I know how to select effective } \\
\text { teaching approaches to guide } \\
\text { student thinking and learning in } \\
\text { language learning. }\end{array}$ & \\
\hline & $\begin{array}{l}\text { I can adapt my teaching to the } \\
\text { learners' prior knowledge. }\end{array}$ & \\
\hline & $\begin{array}{l}\text { I can apply various learning } \\
\text { activities in my lessons. }\end{array}$ & \\
\hline & $\begin{array}{l}\text { I can select appropriate learning } \\
\text { activities for my lessons. }\end{array}$ & \\
\hline & $\begin{array}{l}\text { I know how to organize my } \\
\text { classroom management (e.g., } \\
\text { planning, organizing, } \\
\text { coordinating). }\end{array}$ & \\
\hline
\end{tabular}




\begin{tabular}{|l|l|l|}
\hline Collaboration & Importance of support & Received support \\
\hline $\begin{array}{l}\text { I find that working in our design } \\
\text { team resulted in quality work. }\end{array}$ & $\begin{array}{l}\text { I find it important that our } \\
\text { management shows interest in the } \\
\text { progress of our project }\end{array}$ & $\begin{array}{l}\text { Our management showed interest } \\
\text { in the progress of our project }\end{array}$ \\
\hline $\begin{array}{l}\text { I find that our design team enjoys } \\
\text { working on the implementation of } \\
\text { the CEFR }\end{array}$ & $\begin{array}{l}\text { I find it important that our } \\
\text { management shows interest in the } \\
\text { decisions made about our foreign } \\
\text { language curriculum }\end{array}$ & $\begin{array}{l}\text { Our management showed interest } \\
\text { in the decisions made about our } \\
\text { foreign language curriculum }\end{array}$ \\
\hline $\begin{array}{l}\text { I find that our design team } \\
\text { collaborate effectively. }\end{array}$ & $\begin{array}{l}\text { I find it important that our } \\
\text { management provides us with } \\
\text { (financial) resources for the } \\
\text { development of our foreign } \\
\text { language curriculum. }\end{array}$ & $\begin{array}{l}\text { Our management sometimes } \\
\text { joined design meetings }\end{array}$ \\
\hline $\begin{array}{l}\text { I find that our design team get a } \\
\text { lot of work done. }\end{array}$ & $\begin{array}{l}\text { To improve our foreign language } \\
\text { curriculum, our management has } \\
\text { provided us with time for the } \\
\text { development }\end{array}$ & \begin{tabular}{l} 
\\
\hline $\begin{array}{l}\text { We have collaboratively made } \\
\text { decisions about the content of the } \\
\text { curriculum materials }\end{array}$
\end{tabular} \\
\hline $\begin{array}{l}\text { I find that everyone in our group } \\
\text { provided a significant deal to the } \\
\text { implementation of the CEFR. }\end{array}$ & design meetings & \\
\hline $\begin{array}{l}\text { I find that my own work is better } \\
\text { organized as a result in working } \\
\text { in our team. }\end{array}$ & & \\
\hline
\end{tabular}




\section{LIST OF PUBLICATIONS}

\section{INTERNATIONAL REFEREED JOURNALS}

Huizinga, T., Nieveen, N., Handelzalts, A., \& Voogt, J. M. (2013). Ondersteuning op curriculumontwikkelexpertise van docentontwikkelteams [Support to teacher design teams to foster teachers' curriculum design expertise]. Pedagogische Studiën, 90(3), 4-20.

Huizinga, T., Handelzalts, A., Nieveen, N., \& Voogt, J. M. (2014). Teacher involvement in curriculum design: Need for support to enhance teachers' design expertise. Journal of Curriculum Studies, 46(1), 33-57. doi: 10.1080/00220272.2013.834077

Huizinga, T., Handelzalts, A., Nieveen, N., \& Voogt, J. M. (accepted). Fostering teachers' design expertise in teacher design teams: Conducive design and support activities. The Curriculum Journal.

Huizinga, T., Handelzalts, A., Nieveen, N., \& Voogt, J. M. (submitted). Implementation and evaluation activities in design teams: Opportunities for enhancing teachers' design expertise.

Huiziga, T., Voogt, J. M., Handelzalts, A, Hubers, M. D., Nieveen, N., Pieters, J. M. (submitted). Factors affecting teachers' ability to tackle design challenges.

\section{CONFERENCE PRESENTATIONS}

Huizinga, T., Nieveen, N., \& Voogt, J. (2010, June). De ontwikkeling van een instrument om de curriculumontwerpcompetenties van docenten te meten [The developemnt of an instrument to measure teachers' curriculum design competencies]. Paper presented at Onderwijs Research Dagen, Enschede, The Netherlands.

Huizinga, T., Handelzalts, A., Nieveen, N., \& Voogt, J. (2010, June). Docentontwikkelteams als arrangeurs en (her-)ontwerpers van curriculummaterialen: Opzet formatieve evaluatie interventies [Teacher Design Teams as arrangers and (re-)designers of curriculum materials: Plan for formative evaluation of the interventions]. Round table presented at Onderwijs Research Dagen, Enschede, The Netherlands.

Huizinga, T. (2011, March). Supporting Teacher Design Teams (TDTs) during the (re)design of curriculum materials. Poster presented at the IBR-dag, Enschede, Nederland

Huizinga, T., Handelzalts, A., Nieveen, N., \& Voogt, J. (2011, June). Ondersteuning aan docentontwikkelteams tijdens het gezamenlijk arrangeren van leermiddelen [Support to teacher design teams during the collaborative arrangement of curriculum mateirals]. Paper presented at Onderwijs Research Dagen, Maastricht, The Netherlands. 
Huizinga, T., Handelzalts, A., Nieveen, N., \& Voogt, J. (2011, June). Docentontwikkelteams als arrangeurs en (her-)ontwerpers: Toepassingsmogelijkheden van de storyline-methode [Teacher Design Teams as arrangers and (re-)designers of curriculum materials: Opportunities to apply the storyline method]. Round table presented at Onderwijs Research Dagen, Maastricht, The Netherlands.

Huizinga, T., Handelzalts, A., Nieveen, N., \& Voogt, J. (2011, November). How Foreign Language Teachers Perceive Their Curriculum Design Expertise. Poster presented at ICO Toogdagen, Eindhoven, The Netherlands.

Huizinga, T., Handelzalts, A., Nieveen, N., \& Voogt, J. (2012, April). Teachers' Perceived Expertise in Collaborative Curriculum Design. Poster presented at AERA, Vancouver, Canada.

Huizinga, T., Handelzalts, A., Nieveen, N., \& Voogt, J. (2012, May). The role of external support during collaborative curriculum development: Facilitating the design process or focusing on the designed products? Paper presented at the International PhD seminar, Enschede, The Netherlands.

Huizinga, T. Handelzalts, A., Nieveen, N., \& Voogt, J. (2012, June). Beginnende of expert ontwerper? Veranderingen in ontwerpexpertise van docenten [Novice or expert designer? Changes in teachers' design expertise]. Round table presented at Onderwijs Research Dagen, Wageningen The Netherlands.

Huizinga, T., Handelzalts, A., Nieveen, N., \& Voogt, J. (2012, June). Ondersteunen van docentontwikkelteams: Proces of product? [Supporting teacher design teams: Process or product?] Paper presented at Onderwijs Research Dagen, Wageningen, The Netherlands.

Huizinga, T. (2012, October). Van een papieren raamwerk naar de lespraktijk: Ervaringen van het invoeren van het ERK [From a written framework to classroom pracitces: Experiences of the implementation of CEFR]. Presentation during the final evaluation of the VeldwERKproject of SLO, Utrecht, The Netherlands.

Huizinga, T., Handelzalts, A., Nieveen, N., \& Voogt, J. (2012, November). Supporting Teacher Design Teams: Professional Development Strategies to foster Teachers' Design Expertise. Paper presented at ICO Fall School, Girona, Spain.

Huizinga, T., Handelzalts, A., Nieveen, N., \& Voogt, J. (2013, May). Samen aan de slag: Verwachtingen van docentsamenwerking tijdens het gezamenlijk implementeren van het ERK.[Working together: Expectations of teacher collaboration during the collaborative implementation of CEFR]. Paper presented at Onderwijs Research Dagen, Brussels, Belgium.

Handelzalts, A., Huizinga, A., Nieveen, N., \& Voogt, J. (2013, May). Gezamenlijk curriculum ontwerp en veranderingen in ontwerpexpertise van docenten[Collaborative curriculum design and changes in teachers' design expertise]. Paper presented at Onderwijs Research Dagen, Brussels, Belgium.

\section{OTHER}

Huizinga, T. (2013, November). Design teams: What's in a name? Kansen, mogelijkheden en obstakels van werken in design teams [Design teams: What's in a name? Changes, opportunities and pitfalls of working in design teams]. Keynote presented during the Kick-off session Design Teams ICT-Project, Ghent, Belgium. 


\section{ICO DISSERTATIONS SERIES}

In the ICO Dissertation Series the dissertations of graduate students from faculties and institutes on educational research within the ICO Partner Universities are published: Eindhoven University of Technology, Leiden University, Maastricht University, Open University of the Netherlands, University of Amsterdam, University of Twente, Utrecht University, VU University Amsterdam, and Wageningen University, and formerly University of Groningen (until 2006), Radboud University Nijmegen (until 2004), and Tilburg University (until 2002). The University of Groningen, University of Antwerp, University of Ghent, and the Erasmus University Rotterdam have been 'ICO 'Network partner' in 2010 and 2011. From 2012 onwards, these ICO Network partners are full ICO partners, and from that period their dissertations will be added to this dissertation series.

250. Van de Pol, J.E. (28-09-2012) Scaffolding in teacher-student interaction. Exploring, measuring promoting and evaluating scaffolding Amsterdam: University of Amsterdam

251. Phielix, C. (28-09-2012) Enhancing Collaboration through Assessment \& Reflection [Samenwerking Verbeteren door middel van Beoordeling en Reflectie] Utrecht: Utrecht University

252. Peltenburg, M.C. (24-10-2012) Mathematical potential of special education students Utrecht: Utrecht University

253. Doppenberg, J.J. (24-10-2012) Collaborative teacher learning: settings, foci and powerful moments Eindhoven: Eindhoven University of Technology

254. Kenbeek, W.K. (31-10-2012) Back to the drawing board. Creating drawing or text summaries in support of System Dynamics modeling Enschede: University of Twente

255. De Feijter, J.M. (09-11-2012) Learning from error to improve patient safety Maastricht: Maastricht University

256. Timmermans, A.C. (27-11-2012) Value added in educational accountability: Possible, fair and useful? Groningen: University of Groningen

257. Van der Linden, P.W.J. (20-12-2012) A design-based approach to introducing student teachers in conducting and using research. Eindhoven: Eindhoven University of Technology

258. Noroozi, O. (11-01-2013) Fostering Argumentation-Based Computer-Supported Collaborative Learning in Higher Education Wageningen: Wageningen University

259. Bijker, M.M. (22-03-2013) Understanding the gap between business school and the workplace: Overconfidence, maximizing benefits, and the curriculum Heerlen: Open University of the Netherlands

260. Belo, N.A.H. (27-03-2013) Engaging students in the study of physics Leiden: Leiden University

261. Jong, R.J. de (11-04-2013) Student teachers' practical knowledge, discipline strategies, and the teacher-class relationship Leiden: Leiden University 
262. Verberg, C.P.M. (18-04-2013) The characteristics of a negotiated assessment procedure to promote teacher learning Leiden: Leiden University

263. Dekker-Groen, A. (19-04-2013) Teacher competences for supporting students' reflection. Standards, training, and practice Utrecht: Utrecht University

264. M.H. Knol (19-04-2013). Improving university lectures with feedback and consultation. Amsterdam: University of Amsterdam

265. Diggelen, M.R. van (21-05-2013) Effects of a self-assessment procedure on VET teachers' competencies in coaching students' reflection skills Eindhoven: Eindhoven University of Technology

266. Azkiyah, S.N. (23-5-2013) The effects of Two Interventions - on Teaching Quality and Student Outcome Groningen: University of Groningen

267. Taminiau, E.M.C. (24-05-2013) Advisory Models for On-Demand Learning Heerlen: Open University of the Netherlands

268. Milliano, I.I.C.M. de (24-05-2013) Literacy development of low-achieving adolescents. The role of engagement in academic reading and writing Amsterdam: University of Amsterdam

269. Vandyck, I.J.J. (17-06-2013), Fostering Community Development in School-University Partnerships. Amsterdam: VU Universtiy Amsterdam

270. Hornstra, T.E. (17-06-2013) Motivational developments in primary school. Group-specific differences in varying learning contexts Amsterdam: University of Amsterdam

271. Keuvelaar-Van den Bergh, L. (26-06-2013) Teacher Feedback during Active Learning: The Development and Evaluation of a Professional Development Programme. Eindhoven: Eindhoven University of Technology.

272. Meeuwen, L.W. van (06-09-13) Visual Problem Solving and Self-regulation in Training Air Traffic Control Heerlen: Open University of the Netherlands

273. Pillen, M.T. (12-09-2013) Professional identity tensions of beginning teachers Eindhoven: Eindhoven University of Technology

274. Kleijn, R.A.M. de, (27-09-2013) Master's thesis supervision. Feedback, interpersonal relationships and adaptivity Utrecht: Utrecht University

275. Bezdan, E. ( 04-10-2013) Graphical Overviews in Hypertext Learning Environments: When One Size Does Not Fit All Heerlen: Open University of the Netherlands

276. Bronkhorst, L.H. (4-10-2013) Research-based teacher education: Interactions between research and teaching Utrecht: Utrecht University

277. Popov, V. (8-10-2013) Scripting Intercultural Computer-Supported Collaborative Learning in Higher Education Wageningen: Wageningen University

278. Dolfing, R. (23-10-2013) Teachers' Professional Development in Context-based Chemistry Education. Strategies to Support Teachers in Developing Domain-specific Expertise. Utrecht: Utrecht University

279. Lucero, M.L. (21-11-2013) Considering teacher cognitions in teacher professional development: Studies involving Ecuadorian primary school teachers Ghent: Ghent University

280. Kamp, R.J.A. (28-11-2013) Peer feedback to enhance learning in problem-based tutorial groups Maastricht: Maastricht University

281. Cviko, A. (19-12-2013) Teacher Roles and Pupil Outcomes. In technology-rich early literacy learning Enschede: University of Twente 


\section{DANKWOORD}

\section{'Bedankt' of 'bedankt allemaal'}

is natuurlijk een veel te kort dankwoord, maar eigenlijk wel alomvattend. Het voordeel is wel dat je dan voorkomt dat je mensen vergeet te bedanken.

In de afgelopen jaren heb ik de mogelijkheid gehad om mijn tanden te zetten in het uitvoeren van het promotieonderzoek. Het was zeker geen eenvoudig proces en als ik zelf een storyline zou moeten tekenen van de afgelopen jaren dan wordt de storyline gekenmerkt door hoge pieken en diepe dalen. Pieken op de lijn zijn, onder andere, de AERA in Vancouver, het eerste artikel dat gepubliceerd werd en het prikken van de promotiedatum. De dalen hebben vooral betrekking op het (compleet) herschrijven van artikelen en papers en het uitvallen van scholen in het onderzoek en de daaraan gerelateerde consequenties. Zowel de pieken als de dalen hebben een bijdrage geleverd om mezelf, zowel op onderzoeksmatig, inhoudelijk als op persoonlijk vlak, verder te ontwikkelen.

Het succesvol afronden van het traject was niet mogelijk geweest zonder de hulp en ondersteuning van een aantal mensen.

In de eerste plaats gaat mijn dank uit naar de docenten van de deelnemende scholen uit het VeldwERK-project en de curriculumontwikkelaars van SLO. Zonder jullie was het niet mogelijk geweest om het onderzoek uit te voeren. Jullie boden me de mogelijkheid om een kijkje te nemen in de keuken en mijn onderzoek uit te voeren. Tot slot wil ik de respondenten uit het eerste deelonderzoek bedanken voor de bereidheid om het eigen werken in DOTs toe te lichten.

Mijn promotoren Joke Voogt en Jules Pieters, mijn dagelijks begeleider Adam Handelzalts en referent Nienke Nieveen wil ik bedanken voor de begeleiding en input tijdens het traject. Jullie gaven me de kans om het onderzoek eigen te maken en mijn mening werd ook zeker gehoord. Deze waardering heeft ook geresulteerd in de nominatie en het winnen van de VPO begeleidersprijs 2014. Joke, je hebt me geleerd om (een stuk) beknopter te schrijven en je bewaakte altijd de lijn tussen de onderzoeken. Jules, je hielp me om het overzicht te bewaren en de ontvangen feedback te ordenen. Adam, het promotietraject was voor ons allebei een leerervaring, voor jou als begeleider en voor mij als promovendus. Je maakte vlak voor deadlines tijd vrij in weekenden of 's avonds om nog zaken te bespreken, hetgeen ik zeer gewaardeerd heb. Nienke, als critical friend heb je gedurende het traject gezorgd voor een frisse blik. Daarnaast heb je geholpen bij het afbakenen van het onderzoek en het kunnen aanhaken bij het VeldwERK-project. 
De collega's van Curriculumontwerp \& Onderwijsinnovatie, Onderwijskunde en ELAN wil ik ook bedanken voor de prettige werksfeer. In het bijzonder wil ik Irene VisscherVoerman bedanken. Je hebt me enthousiast gemaakt om onderwijskundig onderzoek uit te voeren, wat voor mij een belangrijke drijfveer is geweest om te beginnen aan het promotietraject. Of het nu ging over onderwijs, onderzoek of om gewoon bij te praten, ik kon altijd van gedachten wisselen met (o.a.) Guido Bruinsma, Maaike Heitink, Gerard Gervedink Nijhuis, Natalie Pareja Roblin, Ayoub Kafyulilo en Sandra Schele.

De collega's van het lectoraat Innovatief en Effectief Onderwijs van Saxion hebben me in de afrondingsfase mentaal ondersteund. Het combineren van een nieuwe baan bij Saxion en de afronding van het proefschrift was niet eenvoudig, maar de geboden flexibiliteit en opbeurende opmerkingen hebben bijgedragen aan de voltooiing.

Edouard Relou wil ik bedanken voor het omslag van dit proefschrift en het vrijmaken van tijd in een drukke periode.

De befaamde (legendarische) 'gameavonden' met Tim en Mireille zorgden voor de nodige ontspanning. Het waren ook de momenten om ervaringen te delen over het onderzoek en de bijbehorende randvoorwaarden. Daarnaast stelden jullie ook altijd kritische vragen over het onderzoek. Ik hoop dat ik jullie bij de afronding van jullie promotieonderzoeken ook op zo'n manier kan ondersteunen!

Maar ook mijn andere vrienden waren belangrijk in het traject: Arnoud, Robert, Vincent, Chris, Vincent en Eline. Jullie vroegen altijd geïnteresseerd naar de voortgang van mijn onderzoek en hebben daardoor de mooie en minder mooie onderdelen van promoveren meegemaakt. Ik hoop dat we in de komende periode weer meer tijd hebben om te socializen.

Tot slot, niks is zo fijn om een thuisfront te hebben dat je volledig steunt en stimuleert. Dorien, je hebt me leren kennen in één van de meest hectische periodes van het promotietraject. De vele avonden dat ik op de bank aan het typen was, terwijl Rembrandt probeerde om de laptop dicht te klappen. Het waren er meer dan me lief was. Gelukkig hebben we straks weer meer tijd om leuke dingen te gaan doen. Papa, mama en Maarten, in de beginfase hebben we het vaak gehad over de verschillen tussen theorie en praktijk en wat wel en niet haalbaar is binnen onderwijsland. Jullie hebben de achtbaan van de afgelopen jaren van heel dichtbij meegemaakt en hebben erg meegeleefd. Het inlevingsvermogen en de gave om elkaar op te beuren was hierbij heel belangrijk. Jullie zorgden er ook voor dat ik niet naast mijn schoenen ging lopen op de momenten dat het proces in een versnelling kwam. Bekende uitspraken daarbij zijn: 'blijf realistisch', 'blijf jezelf en 'werk is belangrijk, maar het moet niet ten koste gaan van alles'.

Tjark Huizinga

Enschede, 2014 